UNIVERSIDADE DE BRASÍLIA

FACULDADE DE ARQUITETURA E URBANISMO

PROGRAMA DE PESQUISA E PÓS-GRADUAÇÃO

MESTRADO EM ARQUITETURA E URBANISMO

ÁREA DE CONCENTRAÇÃO: TECNOLOGIA

SIMULAÇÃO COMPUTACIONAL AMBIENTAL NO SISTEMA BIM: POSSIBILIDADES E LIMITAÇÕES DO CÁLCULO DA LUZ NATURAL

TATIANA SANTANA YEGANIANTZ 
TATIANA SANTANA YEGANIANTZ

\section{SIMULAÇÃO COMPUTACIONAL AMBIENTAL NO SISTEMA BIM: POSSIBILIDADES E LIMITAÇÕES DO CÁLCULO DA LUZ NATURAL}

Dissertação apresentada ao Programa de PósGraduação em Arquitetura e Urbanismo da Universidade de Brasília, como requisito parcial para a obtenção do título de Mestre em Arquitetura e Urbanismo.

ORIENTADOR: PROF. DR. NEANDER FURTADO SILVA. 


\section{Banca examinadora:}

Candidato: Tatiana Santana Yeganiantz

Dissertação defendida e aprovada

Prof. Dr. Neander Furtado Silva- FAU- UnB

Faculdade de Arquitetura e Urbanismo- Universidade de Brasília-UnB

Prof. Dr. Félix Alves da Silva Júnior - FAU- UnB

Faculdade de Arquitetura e Urbanismo- Universidade de Brasília-UnB

Profa. Dr. Alessandra Beatriz C. G. Alves

Faculdade de Engenharia Civil - Universidade Federal do Triângulo Mineiro 


\section{AGRADECIMENTOS}

Agradeço à minha família em especial ao meu pai Levon Yeganiantz, à minha mãe Sonia Ângela de Santana Yeganiantz e irmã Lydia Santana Yeganiantz pelo apoia, incentivo, exemplo e dedicação incondicional.

Ao meu orientador Neander Furtado Silva pelo conhecimento adquirido na concretização da longa jornada deste trabalho. Agradeço também a Ecilamar Lima pela experiência compartilhada.

Aos meus colegas da vida e do mestrado pela amizade. Em especial ao Rafael Gangana pelo companheirismo e paciência. Ao Rodrigo Fernandes, Pedro Praia e Ludmila Andrade pela troca de informações sobre os sistemas BIM.

Agradeço aos membros da banca examinadora pela contribuição para o melhoramento da dissertação.

Á Deus por guiar meus caminhos nesta jornada e pela vida.

A todos que participaram diretamente ou indiretamente deste trabalho meus sinceros agradecimentos. 


\section{RESUMO}

A presente investigação se apoia no fato de que alguns softwares que utilizam os sistemas BIM (Building Information Modeling), como o Revit, estão integrando as funcionalidades dos simuladores ambientais individuais em sua própria estrutura e interface. Isto possibilita a análise do desempenho ambiental e visualização dos resultados diretamente nos sistemas BIM. Considerando este contexto, vimos por meio desta Dissertação verificar e avaliar a contribuição dos sistemas BIM como ferramenta de estudo e avaliação da luz natural no processo de projetação arquitetônica sem a necessidade de exportação do projeto para um simulador ambiental individual. O estudo de caso utilizado como objeto de investigação é o edifício do Tribunal Superior Eleitoral TSE, projetado por Oscar Niemeyer, localizado em Brasília-DF no Setor de Administração Federal Sul (SAFS). O edifício do TSE foi modelado no software Revit para verificação da capacidade de simulação da luz natural em um sistema BIM com integração das funções dos simuladores ambientais em sua interface. Por meio dos resultados obtidos no estudo de caso verificou-se que é possível simular grade parte dos componentes da luz natural por meio do sistema BIM sem a necessidade de exportar o projeto para um software de análise ambiental individual. Contudo verificamos também que a simulação da luz natural no Revit está em processo de transição e ainda não foram integradas todas as funcionalidades do software tomando como referência (Ecotect Analysis), em sua interface.

Palavras-Chave: Simulação da Luz Natural, Sistemas BIM ("Building Information Modeling”), Simuladores Ambientais Individuais. 


\begin{abstract}
The present investigation is supported by the fact that some software that uses Building Information Modeling (BIM), like Revit, are connecting the functionality of computer individual environmental simulation programs into their own structure and interface. This enables the analysis of environmental performance and results viewing directly in the BIM systems. Considering the context, we hereby would like, through this Master's Dissertation, to verify and assess the contribution of BIM software to serve as a tool for study and evaluation of daylighting in the architectural design process without the need for exporting project to individual environmental simulation programs. The case study used as research goal is the seat of the Brazilian Superior Electoral Court (TSE), a building designed by Oscar Niemeyer, situated in Brasilia-DF, at South Sector of Federal Administration (SAFS). The TSE Building was shaped in the Revit software in order to realize the capacity of daylighting simulation into a BIM model with the integration of the environmental simulators functions in its interface. By means of the results obtained with the case study, it has proved possible the simulation of large share of the daylighting components through BIM software programs with no need of exportation the project to individual environmental analysis software. However, we also note that daylighting simulation using Revit is undergoing transition and it has not yet been integrated all Ecotect features in its interface.
\end{abstract}

Keywords: Daylighting simulation, BIM (Building Information Modeling), individual environmental simulation programs. 


\section{SUMÁRIO}

$\begin{array}{ll}1.0 \text { Introdução } & 1\end{array}$

1.1 Relevância do Tema 5

$\begin{array}{ll}1.2 \text { Problemática } & 7\end{array}$

1.3 Objetivo/Hipótese 9

2. Revisão Bibliográfica

2.1 Desenho Sustentável 13

2.2 A Sustentabilidade nos Espaços Urbanos 15

2.3 O Uso da Luz Natural na Arquitetura 17

2.4 Exemplos de Uso Inadequado da Luz Natural em Edificações 23

2.5 Aspectos da Luz Natural 26

2.6 Avaliação da Luz Natural em Projetos Arquitetônicos 28

3.0 Contexto da Arquitetura Digital 30

3.1 Geometrias Não-Euclidianas

3.2 Boas Práticas de Uso e Aplicação da Luz Natural 38

3.2.1 Prefeitura de Londres "City Hall” 38

3.2.2 30 St. Mary Axe 43

3.2.3 Instituto do Mundo Árabe 45

3.2.4 Quadracci Pavillion 45

3.2.5 João Filgueiras Lima (Lelé) /Rede Sarah 46

4.0 Evolução da Representação de Projetos de Arquitetura 50

4.1 Evolução dos Sistemas CAD 54

4.2 Modelagem Paramétrica 59

4.3 Os Sistemas BIM 62

4.4 Benefícios da Utilização dos Sistemas BIM 64

4.5 REVIT 66

$\begin{array}{ll}4.6 \text { ArchiCAD } & 67\end{array}$

4.7 Digital Project da Gehry Technology $\quad 68$

$\begin{array}{ll}4.8 \text { Bentley Systems } & 68\end{array}$

$\begin{array}{ll}4.9 \text { Interoperabilidade } & 69\end{array}$

5.0 Aplicação dos Simuladores Ambientais Individuais 71

5.1 Softwares de Simulação Ambiental Individual /Ecotect Analysis 74

5.2 Integração das Funções dos Simuladores Ambientais Ind.na Plataforma BIM 75 
5.2.2 Estudo do Caminho do Sol e Sombra 78

5.2.3 Desempenho Térmico $\quad 79$

5.2.4 Análise Energética do Edifício $\quad 79$

5.2.5 Visualização de Dados Metereológicos $\quad 80$

6.0 Veículo de Experimentação $\quad 81$

6.1 Procedimentos Metodológicos $\quad 85$

6.2 Levantamento das Informações para Modelagem no Sistema BIM 86

6.3 Levantamento das Informações Referentes as Especificações dos Materiais 91

6.4 Elaboração do Modelo Geométrico Trid. do Edifício do TSE no Sistema BIM 92

6.5 Realização da Simulação da LN no sistema BIM 98

6.5.1 Localização Geográfica do Projeto 98

6.5.2 Configuração do Norte Verdadeiro no Revit 99

6.5.3 Estudos do Caminho do Sol e Sombra 100

6.5.4 Simulação da Iluminância 106

6.5.5 Simulação do Fator de Luz do Dia- FLD 113

6.5.6 Simulação da Luminância 116

6.5.7 Plug-in para Simulação da Luz Natural no Revit 116

6.6 Avaliação dos Resultados Obtidos 119

$\begin{array}{ll}7.0 \text { Conclusão } & 127\end{array}$

8.0 Referências Bibliográficas 131 


\section{ÍNDICE DE ILUSTRAÇÕES}

Figura 1- Processo de Projetação no BIM 3

Figura 2 - Árvore e radiação solar $\quad 6$

Figura 3- Panteão /Roma iluminação zenital 18

Figura 4- Edifício do MEC e Lever House 21

Figura 5- Edificio "Walkie Talkie" 23

Figura 6- Instalação de Tela no Edifício "Walkie Talkie" 24

Figura 7- Hotel Vdara 25

Figura 8- Palácio de Cristal 31

Figura 9- Museu Guggenheim, Frank Gehry (1992) 34

Figura 10- Quinto postulado de Euclides 36

Figura 11- Prefeitura de Londres 38

Figura 12- Simulação acústica do City Hall 39

Figura 13- Rampa sala de reunião do City Hall $\quad 40$

Figura 14- Maquetes com estudos e alterações no projeto 40

Figura 15- Estudo Solar do Edifício $\quad 41$

Figura 16- Diagrama da iluminação solar $\quad 42$

Figura 17- Edifício Swiss Re e Simulação dos ventos 43

Figura 18- Aberturas na fachada e cúpula $\quad 44$

Figura 19- Instituto Mundo Árabe $\quad 45$

Figura 20- Quadracci Pavillion 46

Figura 21- Sheds do Sarah do Rio de Janeiro $\quad 47$

Figura 22- Sheds do Sarah Brasília 48

Figura 23- Rede Sarah de Hospitais 49

Figura 24- Desenho da fachada do Palácio Sansedoni (1340) 51

Figura 25- Utilização do Sketchpad 55

Figura 26- Fluxograma de fatores envolvidos em uma simulação computacional $\quad 72$

Figura 27- Caminho solar no Revit $\quad 79$

Figura 28- Dados climáticos e localização do Autodesk Climate Server em um mapa $\begin{array}{lr}\text { global } & 80\end{array}$

Figura 29- Localização do Tribunal Superior Eleitoral 81

Figura 30- TSE- Fachada Sul/ Edifício Sede $\quad 82$

Figura 31- Tribunal Superior Eleitoral/ Localização $\quad 82$ 
Figura 32- Brises da fachada norte e vista interna /persianas

Figura 33- Brises da fachada norte

Figura 34- Locação e Implantação $\quad 87$

Figura 35- Planta Baixa Térreo -Edifício Sede $\quad 88$

Figura 36- Planta Baixa Primeiro Pavimento -Edifício Sede 89

Figura 37- Planta Baixa Pavimento tipo -Edifício Sede $\quad 90$

Figura 38- Planta Baixa 10 Pavimento -Edifício Sede 91

Figura 39- Planta Baixa do Térreo inserida no Revit 92

Figura 40- Planta Baixa do Primeiro Pavimento inserida no Revit 93

Figura 41- Planta Baixa do Segundo Pavimento inserida no Revit 93

Figura 42- Planta Baixa do Décimo Pavimento inserida no Revit 94

Figura 43- Modelo geométrico tridimensional do edifício do TSE/ Fachada Sul 96

Figura 44- Modelo geométrico tridimensional do edifício do TSE/ Fachada Norte 96

Figura 45- Imagem Renderizada do TSE/ Fachada Sul e Norte 97

Figura 46- Localização geográfica do projeto no Revit 99

Figura 47- Norte de Projeto 99

$\begin{array}{ll}\text { Figura 48- Norte Verdadeiro } & 100\end{array}$

Figura 49- Caixa de Diálogo "Sun Setting” 101

Figura 50- Caminho Solar e Sombras às 8, 10, 12,15 17 horas respectivamente solstício $\begin{array}{ll}\text { de inverno } & 102\end{array}$

Figura 51- Caminho Solar e Sombras às 8, 10, 12,15 17 horas respectivamente solstício de verão

Figura 52- Caminho Solar e Sombras às 8, 10, 12,15 17 horas respectivamente equinócio /outono

104

Figura 53- Caminho Solar / Sombras às 8, 10, 12,15 e 17 horas respectivamente equinócio/primavera 105

Figura 54- Vista utilizada para simulação da iluminância 107

$\begin{array}{ll}\text { Figura 55- Caixa de Diálogo } & 108\end{array}$

Figura 56- Simulação da iluminância solstício de inverno (21/06/2016) ás 8 horas 109

Figura 57- Simulação da iluminância solstício de inverno (21/06/2016) às 10 horas 109

Figura 58- Simulação da iluminância solstício de inverno (21/06/2016) às 12 horas 109

Figura 59- Simulação da iluminância solstício de inverno (21/06/2016) às 15 horas 110

Figura 60- Simulação da iluminância solstício de inverno (21/06/2016) às 17 horas 110

Figura 61- Simulação da iluminância solstício de verão (21/06/2016) às 8 horas 110 
Figura 62- Simulação da iluminância solstício de verão (21/06/2016) às 10 horas 111

Figura 63- Simulação da iluminância solstício de verão (21/06/2016) às 12 horas 111

Figura 64- Simulação da iluminância solstício de verão (21/06/2016) às 15 horas 111

Figura 65- Simulação da iluminância solstício de verão (21/06/2016) às 17 horas 112

Figura 66- Simulação no Ecotect do FLD 114

Figura 67- Caixa de dialogo para selecionar simulação do FLD 115

Figura 68- Simulação do FLD na data de 21 de junho às 8 horas 116

Figura 69- Simulação da LN por meio do LA/R 117

Figura 70- Simulação da iluminância no "Insight 360" 118

Figura 71- Legenda Simulação Iluminância 118 


\section{LISTA DE TABELAS}

Tabela 1- Iluminância por Classe de Tarefa Visual

106

Tabela 2- Quadro Geral de Resultados da Avaliação do Revit Utilizando como Benchmark o Ecotect 


\title{
1.0 INTRODUÇÃO
}

\begin{abstract}
"O início da arquitetura é o espaço vazio, caracterizado por Platão em Timeu como "a mãe e receptáculo de todas as coisas criadas e visíveis e de certa forma sensíveis". A arquitetura é a arte das distinções no espaço contínuo, por exemplo, entre o cheio e o vazio, o interior e o exterior, a luz e a escuridão, o calor e o frio" (MITCHELL, 2008, p. 15).
\end{abstract}

$\mathrm{O}$ arquiteto procura representar e ordenar o espaço a ser construído. Segundo Mitchell (2008), a arquitetura é determinada basicamente por nossa capacidade de criar e sentir diferenciações físicas do espaço. Frequentemente utilizamos desenhos e fotografias para observar um edifício, ao invés de experimentar o objeto real, contudo este tipo de observação pode ser enganosa. As sensações de calor e frio, iluminação, ar parado e a brisa, odores, sons, sensação de movimento podem ser igualmente importantes para experimentação e compreensão da arquitetura. Neste contexto o uso de ferramentas que possibilitam "experimentar" o objeto antes de sua construção é algo fundamental no processo de planejamento do espaço. Atualmente, acreditamos que a possibilidade de estudos mais aprofundados dos objetos e espaços a serem construídos está se tornando uma realidade por meio do uso dos sistemas BIM (Building Information Modeling) (MITCHELL, 2008, p. 15).

As falhas na metodologia tradicional de projeto e o aumento da complexidade das edificações criaram o ambiente propício para o surgimento de diversos especialistas. Desta forma os projetos foram subdivididos, desenvolvidos separadamente e unidos somente no final do processo. Estes procedimentos geraram diversas falhas de compatibilização de projetos e falta de detalhamentos. Assim o gerenciamento e compatibilização de informações se tornou fundamental para o sucesso da tarefa de projetar e construir.

O processo projetual assim como o sistema $\mathrm{CAD}$, que significa projeto assistido por computador (Computer Aided Design), tem passado nas últimas décadas por contínuas transformações. Todos os sistemas CAD geram arquivos digitais, cujos mais antigos produzem desenhos bidimensionais de documentação do projeto para plotagem que substituíram as pranchetas. Esses desenhos consistem principalmente em vetores, tipos de linhas associadas e identificação de camadas. Devido ao desenvolvimento destes sistemas, informações adicionais foram sendo acrescentadas a esses arquivos para permitir que dados e textos sejam associados ao projeto. Com o advento da 
modelagem tridimensional foram adicionadas definições avançadas e ferramentas complexas de geração de superfície (EASTMAN et al, 2008, p.12).

Eastman 2008 afirma que "Ao passo que os sistemas CAD se tornaram mais inteligentes e mais usuários desejam compartilhar dados associados ao projeto (em desenvolvimento), o foco transferiu-se dos desenhos e das imagens tridimensionais para os próprios dados". Os avanços da tecnologia permitiu que os projetos fossem desenvolvidos em plataformas tridimensionais nas quais todas as informações do projeto são integradas, paramétricas, e passíveis de simulações.

Os sistemas BIM podem ser traduzidos como Modelagem de Informação da Construção e constituem um processo de desenvolvimento de projetos de arquitetura e engenharia que modificou o conceito de representação de ideias através do desenho geométrico. MITCHELL em 1994 antecipava a provável evolução da tecnologia computacional ao afirmar que:

\begin{abstract}
"Com o desenvolvimento da tecnologia, os modelos digitais serão executados com controles centrais na prática do processo de projetação. Serão utilizados softwares sofisticados de edição e gerenciamento, que receberão "inputs" de arquitetos, construtores, e agentes de softwares inteligentes e informações extraídas de bancos de dados online. Produzirão "outputs" para visualização de sistemas, desenhos e geração de relatórios, grandes tipo de analise crítica do software, sistemas de prototipagem rápida e sistema CAD/CAM"(MITCHEL E MCCULLOUGH,1994. apud MARTINS, 2011, p.40).
\end{abstract}

A citação acima vem sendo concretizada por meio das mudanças e evolução ocorridas nos sistemas CAD. Os sistemas BIM que constituem uma evolução do CAD, são capazes de modelar não somente a geometria dos elementos construtivos, mas também suas propriedades, comportamento e relação com outros componentes. $\mathrm{O}$ modelo nos sistemas BIM possui todas as informações necessárias durante o ciclo de vida da edificação. Estas características possibilitam realização de uma série de funções tais como: análise ambiental, estudo da iluminação solar, estimativa de custo, fabricação digital, detecção de interferências com sistemas estruturais, compatibilização de projeto, etc.

Os sistemas BIM são classificados entre os mais promissores desenvolvimentos da tecnologia voltada para Arquitetura, Engenharia e Construção (AEC). Nos sistemas BIM o modelo virtual de uma edificação é construído de forma digital contendo a geometria exata e os dados relevantes para dar suporte à construção, à fabricação e ao fornecimento de insumos necessários para execução da construção (EASTMAN et al, 2008, p.1). 
O uso dos sistemas BIM permite que a geometria do modelo seja representada pela combinação de vetores e superfícies sólidas e como resultado temos uma imagem realística bidimensional ou tridimensional do edifício. Neste modelo os objetos representam os componentes da edificação, tais como porta, janela, parede, vigas, pilares, telhado, contendo o reconhecimento de suas propriedades e comportamento de seus materiais, ao invés de linhas, pontos e outras primitivas geométricas. Assim estes componentes podem ser entendidos como tais pelos sistemas, permitindo que sejam extraídas dos modelos digitais as mais variadas informações, inclusive tabelas de quantitativos.

Os sistemas BIM possuem parâmetros que tornam o projeto um modelo virtual único contendo todas as informações do edifício que podem ser compartilhadas por todos os envolvidos em sua construção. Esses dados podem ser utilizados para verificações, análises estruturais, quantificação de materiais e serviços, e planejamento de obra, conforme ilustrado na figura abaixo.

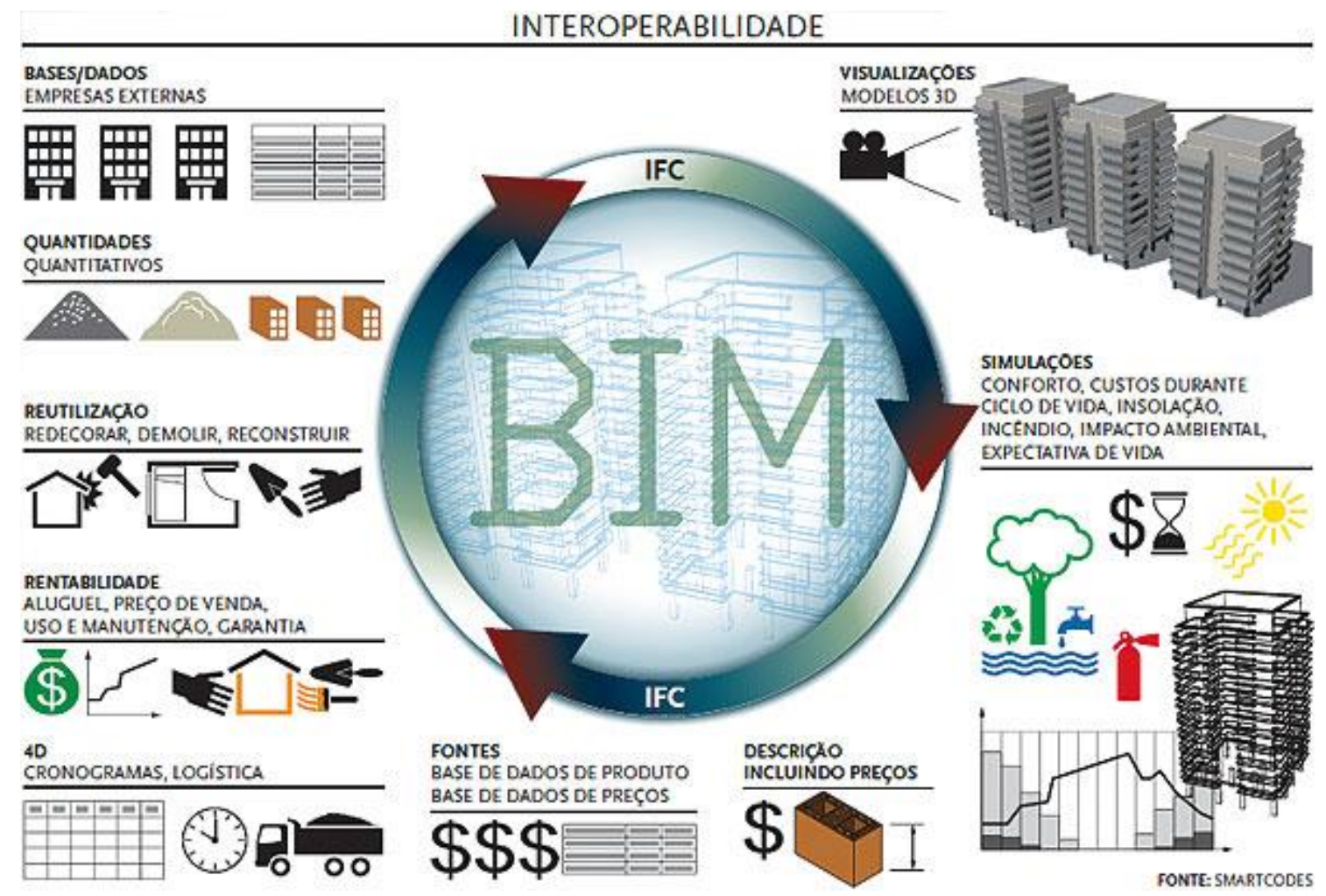

Figura 1: Processo de Projetação no BIM

Fonte: http://au.pini.com.br/arquitetura-urbanismo/208/bim-quem-e-quem-224333-1.aspx

Contudo, na Arquitetura, Engenharia e Construção (AEC) equivocadamente algumas pessoas que acreditam que os sistemas BIM são apenas o uso de um software. Apesar do software ser uma parte necessaria do processo, o conceito dos sistemas BIM vai além de sua aplicação. Quando nos referimos aos sistemas BIM, estamos discutindo 
a metodologia ou processo criado pelos mesmos. Um modelo BIM, por outro lado, é um termo gramaticalmente incorreto que se tornou de alguma forma comum para se referir especificamente ao modelo digital criado em um software que utiliza o sistema BIM (KRYGIEL e NIES, 2008, p. 27).

Os sistemas BIM promovem um método avançado de trabalho colaborativo usando um modelo criado a partir de informações coordenadas e consistentes. Possibilitam obter informações sobre todo o edifício em um conjunto completo de documentação armazenada em uma base de dados integrada. Todas as informações são paramétricas e interconectadas.

O processo viabiliza a tomada de decisões nas etapas iniciais do projeto, o desenvolvimento de documentação de melhor qualidade e a avaliação de alternativas para projeto sustentável com menor gasto de energia, usando a análise antes do início da construção. Consequentemente possibilita o estudo de novas alternativas de projeto e aumenta a possibilidade de experimentação e avaliação do comportamento da edificação.

Os meios computacionais desde a concepção projetual até sua fabricação desempenham o papel agregador de todas as informações de projeto em um mesmo contexto permitindo maior clareza e controle das soluções representadas. A tecnologia computacional digital, quando bem utilizada, pode deixar de ser simples representação e se transformar em um meio de estudo, exploração e testes das soluções propostas.

A tecnologia da informação e comunicação está modificando o comportamento da sociedade e estabelecendo novos paradigmas de conceituação, desenvolvimento e execução dos objetos arquitetônicos. A evolução do projeto concebido digitalmente e seu impacto crescente na prática arquitetônica criam a necessidade de repensar as teorias e metodologias da atual concepção arquitetônica.

A nova metodologia de simulação utilizada por meio do computador está sendo desenvolvida tanto no ambiente acadêmico como comercialmente. Compreende uma ampla gama de parâmetros incluindo iluminação natural e artificial, suprimento energético, ventilação, temperatura, circulação de pedestres nos ambientes, entre outras. Consequentemente resulta em construções mais avançadas e sustentáveis.

As ferramentas de avaliação ambiental, quando utilizadas desde o início do projeto, contribuem para evitar desperdícios de materiais, energia, tempo, mão-de-obra. Reduzem os custos decorrentes de reconstrução tornando o ambiente mais saudável para os seus usuários. São ferramentas importantes que podem auxiliar o arquiteto na tomada 
de decisão no processo de projetação, no sentido de obter uma melhor solução de conforto ambiental. Esses instrumentos de simulação constituem em avanço, pois permitem realizar análises que só seriam possíveis por meio de cálculos complexos ou da construção de protótipos em escala reduzida e medição in loco (AMORIM, 2006, p. $1)$.

\subsection{RELEVÂNCIA DO TEMA}

O desenvolvimento de novas tecnologias na área de sistemas estruturais, produção de vidro, elevadores, sistemas de iluminação e de climatização artificial contribuíram para que as edificações passassem a ser projetadas sem considerar a adequação ao clima local. $\mathrm{O}$ arquiteto se viu liberado para busca de novos paradigmas que não fossem resultantes da consideração de elementos naturais. Contudo, a crise energética da década de 1970 e seu consequente aumento de preço forçou todos os setores a reavaliar suas práticas. Além disto, o consumo energético dos edifícios pode resultar em consideráveis desperdícios, poluição, redução da camada de ozônio e aquecimento global. Atualmente a crescente busca pelo uso racional de energia é uma realidade nas principais nações do mundo.

A radiação solar é tanto fonte de calor quanto fonte de luz natural. O sol é de extrema importância no estudo da eficiência energética na arquitetura. É possível tirar partido do mesmo ou evitar sua luz e calor em um espaço projetado. O critério mais sábio para definir o que fazer é utilizar como premissas básicas o conforto térmico e visual dos ocupantes e a economia energética (LAMBERTS et al, 1997, p. 29).

\footnotetext{
"A radiação solar é um dos mais importantes contribuintes para o ganho térmico em edifícios. Na escala da edificação, a transferência de calor por radiação pode ser dividida em cinco partes principais: radiação solar direta (onda curta)(1), radiação solar difusa (onda curta)(2), radiação solar refletida pelo solo e pelo entorno(onda curta)(3), radiação térmica emitida pelo solo aquecido e pelo céu (onda longa)(4) e radiação térmica emitida pelo edifício(onda longa)(5). As duas primeiras (1 e 2$)$ são variáveis macroclimáticas. A radiação de onda curta refletida pelo solo e pelo entorno (3) depende das características da superfície refletora (albedo). O albedo é uma variável adimensional, relativa a cada tipo de superfície refletora. Quanto maior o albedo, maior a capacidade da superfície de refletir a radiação - uma superfície gramada, por exemplo, tem albedo de 0,2, que significa que apenas $20 \%$ da radiação solar incidente é refletida" (LAMBERTS et al, 1997, p.36).
}

A formação de "ilhas de calor" dentro dos limites da cidade ocorre em função não somente da produção de calor gerada pelas atividades dos seres humanos, mas também pela abundância de materiais, como o asfalto, cimento, edificações e veículos. Além do aumento de temperatura durante o dia, há uma redução do resfriamento durante a noite, 
por causa da grande inércia térmica dos edifícios. Esses fatores são provenientes da urbanização, em contraste com o terreno natural.

O conforto térmico e visual dos espaços é fortemente dependente do projeto de urbanismo. $\mathrm{O}$ arquiteto, a partir de seu desenho, vem a ser responsável, não só pelas condições internas do edifício, como também pelo entorno climático. Nesse contexto, o clima local será determinante nas decisões de projeto (CORBELLA e YANNAS, 2003, p. 25).

No planejamento de espaços urbanos a radiação solar pode ser interceptada pelos elementos vegetais e topográficos do local. A vegetação é diferente de outras obstruções no bloqueio da radiação solar. As árvores com folhas caducas, por exemplo, podem sombrear a edificação no verão, enquanto no inverno permitem a passagem do sol. Em locais arborizados, a vegetação pode interceptar entre $60 \%$ a $90 \%$ da radiação solar, causando uma redução da temperatura da superfície do solo. Isto acontece, pois a vegetação absorve parte da radiação solar para seu metabolismo (fotossíntese). Assim, é essencial a escolha correta da vegetação que será utilizada em espaços urbanos de acordo com as características do clima e do local (LAMBERTS et al, 1997, p.35).

A Figura 2 representa a absorção e reflexão da radiação solar por uma árvore. As árvores absorvem grande quantidade de radiação solar que é utilizada no seu processo metabólico e refletem uma quantidade menor quando comparada a superfícies edificadas. A capacidade de filtragem da vegetação aumenta quanto maior for o número de folhas.

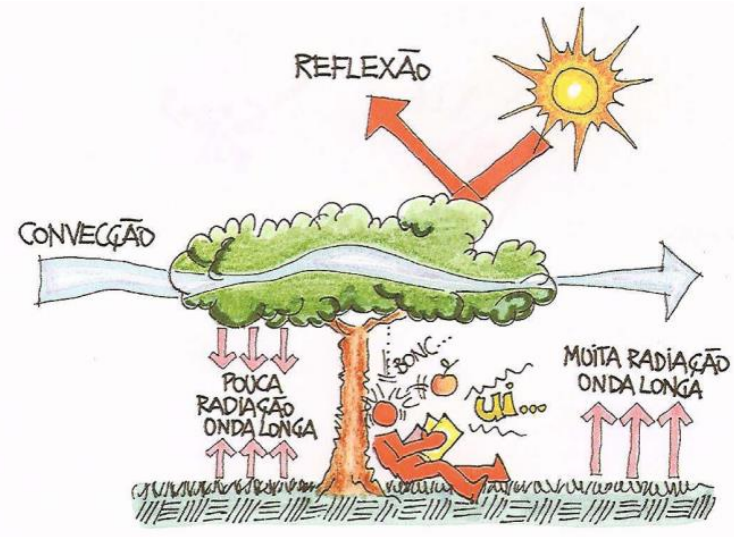

Figura 2 - Árvore e radiação solar Fonte: Lamberts et al, 1997.

O desenho do espaço deve ser condicionado e adaptado às características do meio, tais como topografia, revestimento do solo, ecologia, latitude, clima e princípios históricos. Contudo, a prática do desenho urbano não tem considerado os impactos 
provocados no ambiente, repercutindo não apenas no desequilíbrio do meio como também no conforto e salubridade das populações urbanas. No sentido de fazer uma correta transformação do meio físico é necessária uma organização das informações sobre elementos físicos e ambientais, principalmente sobre o clima: temperatura, umidade, precipitação, velocidade de direção do vento e insolação (ROMERO, 2001, p. 9).

O conceito de espaço sustentável, seja ele uma área urbana ou edificação, implica em atender uma série de requisitos que envolvem adequação do espaço construído ao meio climático; minimizar perdas e produção de resíduos; racionalização do consumo de energia; aproveitamento racional dos recursos da natureza; e o uso otimizado de recursos renováveis (AMORIM, 2007, p. 7).

Neste contexto, o estudo prévio dos aspectos ambientais que envolvem o projeto é de suma importância para a criação de uma arquitetura sustentável com responsabilidade ambiental que contribui para uma melhor qualidade de vida e conforto dos usuários e menor consumo de energia.

Partindo da necessidade de contribuir para minimizar a degradação ambiental, por meio da utilização de técnicas disponíveis de simulação, o presente estudo teve como objetivo verificar as funções realizadas por meio de um sistema BIM para o estudo e cálculo da Luz Natural feitos por um software (REVIT Arquitetura), incluindo a integração das funções de um simulador ambiental individual (Ecotect Analysis) em sua interfase. A transição desta tecnologia é recente sendo de grande importância para estudos e elaboração de projetos sustentáveis.

\subsection{PROBLEMÁTICA}

As técnicas computacionais estão cada vez mais integradas ao processo de projetação. Os projetos de arquitetura e urbanismo podem ser beneficiados por meio das técnicas de simulação da luz natural. Estas permitem avaliar previamente as condições de conforto visual, computar os diversos níveis de iluminação em diferentes pontos do ambiente possibilitando ajustes necessários antes da execução do projeto. Apesar disso, não há uma avaliação da abrangência da utilização dessas técnicas como parte integrante do processo de projetação.

O uso da simulação computacional ambiental no processo projetual está crescendo principalmente nos grandes escritórios internacionais como: Foster + Partners, T.R.Hamzah \& Yeang e Mario Cucinella Architects. Contudo no Brasil está 
prática encontra-se mais concentra em meios acadêmicos (SARAMAGO e BORTOLI, 2012, p. 348). Os arquitetos e urbanistas muitas vezes encontram dificuldades para a utilização destes instrumentos devido a sua complexidade, interfaces não amigáveis, manuais de usuários incompletos e falta de conhecimento (CHRISTAKOU, 2004, p.03).

Verifica-se que em grande parte dos projetos de arquitetura e espaços públicos de Brasília não há preocupação com o controle da luz natural. Em consequência disto, são criados ambientes inadequados devido à falta de incidência da luz solar ou excesso da mesma, causando, portanto, desconforto visual e consequentemente térmico. Assim como em edificações fechadas, em espaços abertos pode-se avaliar também a qualidade do desempenho ambiental, por meio de programas de computação específicos para essa tarefa.

O estudo da iluminação nos projetos de arquitetura precisa ser desenvolvido ainda na fase de concepção da proposta projetual. Isto é necessário porque grande parte das variáveis relacionadas ao uso da luz natural nos ambientes, tais como orientação e posicionamento do projeto como um todo, e especificamente do tamanho e orientação das aberturas são definidas ainda nessa fase (SILVA e CHRISTAKOU, 2007, p. 50).

Embora seja cada vez mais complexa, eficiente e sofisticada, a simulação ambiental computacional tem suas limitações e desvantagens. A elaboração e preparação dos dados de entrada são complexas e demandam tempo maior, de forma geral, do que aquelas relacionadas à simulação propriamente dita. A qualidade da saída depende da precisão dos dados de entrada no que se refere ao preparo e edição dos dados relativos à geometria, às propriedades físicas da luz, do clima e dos materiais. Desta forma, o tempo gasto na execução dos cálculos depende da complexidade do modelo, da implementação do algoritmo a ser executado e da capacidade de processamento do equipamento utilizado (SILVA, CRISTAKOU, 2007, p.51).

Os simuladores ambientais devem ser capazes de modelar ou reconhecer o modelo quando este é importado de outro software. No entanto, não existem estudos detalhados sobre os tipos de dados que podem ser transferidos para um software de simulação ambiental, mas apenas relatos sobre os formatos que podem ser exportados entre os diversos sistemas. Especificamente não tratam da questão sobre quais informações podem ser transportadas e reconhecidas (MARTINS, 2011, p. 211).

Por isso, acredita-se que um dos motivos da baixa utilização destes softwares no início do processo de projetação é decorrente das dificuldades de modelar o projeto diretamente nos simuladores existentes. Devido às suas limitações representacionais, 
estes utilizam recursos de simplificação da realidade para diminuir a quantidade de cálculos a serem feitos nas simulações. Outra dificuldade encontrada é com relação aos recursos de importação e exportação de dados entre os modeladores e simuladores ambientais, pois, muitas vezes, nestas transferências algumas informações são perdidas requerendo do arquiteto o retrabalho de inseri-las novamente ao projeto.

Diante deste contexto, observa-se, muitas vezes que a interoperabilidade entre os softwares não é integral resultando na necessidade do projetista re-modelar o projeto em um software de simulação ambiental, desta forma desestimulando o uso do mesmo. Contudo está ocorrendo um processo de integração das funções dos simuladores ambientais individuais nos sistemas BIM. A título de exemplo podemos citar a integração das funcionalidades do Ecotect Analysis na família de produtos do Revit. Desde 20 de março de 2015 as licenças do Autodesk Ecotect Analysis não estão mais disponíveis para compra. Este pode ser utilizado apenas por aqueles que já possuem a licença.

O presente estudo se baseia nas seguintes questões: Qual a contribuição dos sistemas BIM como ferramenta de simulação, estudo e avaliação da luz natural nos projetos de arquitetura? Os recursos de simulação e avaliação da luz natural que já foram integrados ao sistema BIM estudado nesta pesquisa correspondem àqueles disponíveis nos simuladores individuais? Esta integração permite simular a luz natural em formas arquitetônicas diferentes do ângulo reto ou existem limitações? Ao utilizar a simulação integrada é necessário acrescentar algum "plug-in" ao software?

\subsection{OBJETIVO/ HIPÓTESE}

A presente investigação pressupõe que os sistemas BIM estão integrando os recursos dos simuladores ambientais individuais (standalone), em sua própria estrutura e interface, possibilitando a análise do desempenho ambiental e visualização dos resultados diretamente no ambiente de projeto. Este processo de integração dos simuladores ambientais aos sistemas BIM pode permitir que a exportação do projeto deixe de ser uma necessidade para o cálculo da luz natural.

A Autodesk afirma que integrou os recursos contidos no Ecotect Analysis à familia de produtos do Revit. Esta mudança permitiria que a Autodesk transferisse recursos, maximizando os esforços de desenvolvimento nos sistemas BIM e soluções baseadas em nuvem para a construção de análise de desempenho ambiental e visualização dos resultados no processo de projetação. 
A solução baseada em nuvem refere-se à utilização da memória e capacidade de armazenamento, simulação, renderização e cálculo do projeto em computadores e servidores compartilhados e interligados por meio da internet. Viabiliza a simulação ambiental do projeto de forma rápida eliminando o longo tempo de espera nos laboratórios de informática. Os dados do modelo são enviados para a nuvem de processamento, o que permite continuar trabalhando enquanto a análise está sendo realizada. Isto significa que os dados do projeto serão enviados para um computador remoto operado pela Autodesk com objetivo de aumentar a capacidade de processamento e flexibilidade. (KRYGIEL, 2014, p. 346)

O objetivo do trabalho é verificar e avaliar qual a contribuição dos sistemas BIM como ferramentas de estudo e avaliação da luz natural nos processos de projetação arquitetônica e verificar quais os parâmetros referentes à luz natural é possível simular e visualizar no sistema BIM.

Neste contexto a hipótese desta dissertação é que os sistemas BIM podem contribuir como ferramenta de estudo e avaliação da luz natural no processo de projetação arquitetônica sem a necessidade de exportação do projeto para um simulador ambiental individual. 


\subsection{REVISÃO BIBLIOGRÁFICA}

O uso do computador no processo de elaboração de projeto arquitetônico está evoluindo e amadurecendo, transformando a forma de concepção e execução da arquitetura. A arquitetura dos tempos modernos é caracterizada pela possibilidade pioneira de obter vantagens das inovações oferecidas pelas ciências e tecnologias atuais. A relação entre esta nova tecnologia e a arquitetura caracteriza um marco fundamental do que hoje constitui os projetos de vanguarda. A ortogonalidade da geometria Euclidiana é ampliada possibilitando a concepção de formas diferenciadas e únicas com maior liberdade.

Atualmente (2016) contamos com tecnologias digitais avançadas para projetação e construção tais como os programas de computação gráfica tridimensional e simuladores que preveem o comportamento ambiental das edificações e espaços urbanos. A arquitetura contemporânea pode fazer uso destas ferramentas computacionais para viabilizar um projeto ambientalmente sustentável com o menor impacto ambiental possível, redução de custos energéticos, e uso de energia renovável.

A introdução de software de modelagem digital tridimensional e novas técnicas de construção viabilizaram uma série de possibilidades e desafios de projetação e construção de formas ousadas e complexas, as quais, por meio dos recursos tradicionais, seriam inviáveis ou muito onerosas para serem executadas. Podemos citar como exemplo o Museu Guggenheim em Bilbao do arquiteto Frank Gehry que explorou de maneira aprofundada as curvas complexas, mostrando que é possível através da tecnologia atual e novos métodos de projetação elaborar e produzir formas diferenciadas na arquitetura.

\footnotetext{
"As tecnologias digitais estão modificando a prática da arquitetura de forma que poucos foram capazes de antecipar. Na realidade conceitual a arquitetura computacional e digital de espaços topológicos usa geometrias não-euclidianas, sistemas cinéticos e dinâmicos, algoritmos genéticos que estão substituindo a tecnologia do passado. Os processos de projetação digitalmente conduzidos, caracterizados pela dinâmica aberta e transformações consistentes mais imprevisíveis da estrutura tridimensionais que estão dando subsídio para novas possibilidades arquitetônicas" (KOLAREVIC, 2003, p. 3).
}

A liberdade criativa e volumétrica do arquiteto fica limitada quando se utilizava apenas ambientes bidimensionais para projetação. As representações bidimensionais de largura, altura e profundidade não permitem compreender o espaço a ser construído de forma global. Neste sentido, em 1948, mesmo antes da criação dos computadores e 
software de representação tridimensional, Zevi criticou a projetação bidimensional como forma de compreensão do espaço arquitetônico projetado.

\begin{abstract}
“...o caráter essencial da arquitetura - o que a distingue das outras atividades artísticas - está no fato de agir com um vocabulário tridimensional que inclui o homem. A pintura atua sobre duas dimensões, a despeito de poder sugerir três ou quatro delas. A escultura atua sobre três dimensões, mas o homem fica de fora, desligado, olhando do exterior as três dimensões. Por sua vez, a arquitetura é como uma grande escultura escavada, em cujo interior o homem penetra e caminha" (ZEVI, 1996, p. 17).
\end{abstract}

A citação acima evidencia a importância de pensar a arquitetura de forma holística na qual devemos incluir todos os aspectos que influenciam o espaço a ser projetado. Esta abordagem facilita a tomada de decisão do projetista, pois possibilita visualizar as formas, texturas, contrastes, o contexto do espaço projetado e permite percorrê-lo interna e externamente. Por meio das tecnologias computacionais, formas inovadoras e livres vêm sendo desenvolvidas, introduzindo um novo tipo de arquitetura, isto é, a "arquitetura digital". Neste sentido, atendendo a necessidade de representação tridimensional apresentada por Zevi, autores mais recentes como Kolarevic, apresentam uma gama de possibilidades oferecidas pelas ferramentas computacionais digitais.

\begin{abstract}
"A capacidade generativa e criativa juntamente com os avanços da manufatura já adquiridas na área automotiva, aeroespacial e construção naval oferecem novas oportunidades para o projeto arquitetônico. As implicações são vastas no processo de reestruturação já que a arquitetura se transforma em parte na pesquisa experimental de geometrias topológicas, e em parte da orquestração computacional de produção de materiais robóticos e outra parte numa escultura, geradora cinemática do espaço, como observado por Peter Zellner” (KOLAREVIC, 2003, p. 3).
\end{abstract}

Os avanços da tecnologia de softwares de simulação ambiental têm por objetivo a construção de espaços confortáveis do ponto de vista bioclimático. No caso estudado nesta dissertação, o foco é o estudo da luz natural em projetos de arquitetura. A presente revisão bibliográfica consiste na apresentação dos seguintes assuntos: a importância e evolução histórica do uso da luz natural e a sustentabilidade nos projetos de arquitetura e espaço urbano; conceitos importantes sobre aspectos da luz natural como: luminância, iluminância, brilho e ofuscamento; sustentabilidade na arquitetura, exemplos de edifícios em cujos projetos novas tecnologias foram utilizadas no cálculo da luz natural, uso inadequado de cortinas de vidro em edificações e o contexto da arquitetura digital.

Posteriormente iremos discorrer os seguintes assuntos: a evolução da representação de projetos de arquitetura, novas tecnologias no processo de projetação por meio do projeto assistido por computador (Computer Aided Design- CAD), Modelagem da Informação da Construção (Building Information Modeling - BIM), 
modelagem paramétrica, softwares BIM, simulação computacional ambiental, integração e interoperabilidade dos softwares de simulação ambiental individual com os sistemas BIM e análise na luz natural no Revit.

\subsection{DESENHO SUSTENTÁVEL}

Antes de iniciar as discussões devemos esclarecer e formalizar os conceitos de verde ("Green") e sustentável. A palavra verde pode significar ideias diferentes de acordo com a formação de cada individuo. Este conceito se tornou popular nos últimos anos, fora do grupo de ambientalistas. Em 2005 quando alguém afirmava que estava projetando uma edificação verde era necessário acrescentar que a mesma seria ambientalmente amigável. Em resumo, um edifício verde (“Green Building”) ocasionaria menor impacto ao meio ambiente que aqueles tradicionais construídos nas últimas três décadas. No entanto, apenas recentemente é possível quantificar este impacto (KRYGIEL e NIES, 2008, p. 9).

A linguagem industrial tem tradicionalmente usado o termo verde para designar sustentável. Isto tem tornado a definição de desenho sustentável mais complexa e o resultado é um grande progresso na forma de pensar as construções. Um projeto sustentável é melhor que o "verde", porque o conceito de sustentabilidade é mais amplo e inclui considerações além dos relacionados com ambiente natural. A título de exemplo, a construção verde de 1990 incluía apenas alguns materiais reciclados. No entanto, as construções de hoje que enfatizam a sustentabilidade consideram todo o ciclo de vida do produto minimizando o impacto negativo sobre o meio ambiente. Os projetistas, empreiteiros e empreendedores em geral consideram a extração do material primário, localização, natureza do processo, durabilidade e possibilidade de reciclagem dos produtos utilizados na construção (KRYGIEL e NIES, 2008, p. 10).

A comissão internacional sobre meio ambiente e desenvolvimento, também conhecida como Comissão Brundtland elaborou em 1987 o melhor conceito de sustentabilidade no relatório das Nações Unidas por meio do seguinte texto: "O desenvolvimento sustentável satisfaz as necessidades do presente sem comprometer a capacidade das gerações futuras para satisfazer suas próprias necessidades.” (KRYGIEL e NIES, 2008, p. 10).

Segundo Corbella e Yannas (2003), a arquitetura sustentável consiste em projetar edifícios visando o aumento da qualidade de vida do ser humano no ambiente construído e no seu entorno. Integrando-o com as características da vida e do clima local, de forma a 
consumir a menor quantidade de energia compatível para resultar em um mundo menos poluído para as futuras gerações.

A sustentabilidade das cidades passa a ser uma exigência dos núcleos urbanos contemporâneos, assim ações que significam baixo gasto de energia e aplicação de energias alternativas, reciclagem, baixo impacto ambiental e não retirada da vegetação nativa são importante para o ambiente urbano. As cidades muitas vezes apresentam temperaturas mais elevadas que áreas com vegetação nativa e áreas rurais. Este aquecimento das áreas urbanas chamado de ilha de calor é resultado dos variados padrões de refletância dos diferentes matérias usados na construção civil. Neste contexto a vegetação é de grande importância na regulação do clima, pois o crescimento das plantas está ligado a absorção de $\mathrm{CO} 2$ atmosférico e ao controle dos gases do efeito estufa. A absorção de água e a transpiração das plantas são fundamentais para manter o ciclo hidrológico. Além disto, reduzem a temperatura e amplitude térmica local.

\footnotetext{
"A alteração das características térmicas das superfícies das cidades, decorrente da presença de edificações e materiais de construção quando comparada as áreas verdes, é uma das maiores modificações associadas a urbanização. Estas superfícies impermeáveis têm uma alta capacidade de absorver e re-irradiar calor, aumentando a temperatura ambiental e permitindo a formação de ilhas de calor nas cidades" (ROMERO e BURGOS, 2010, p.78).
}

O conceito de sustentabilidade está relacionado a todas as atividades urbanas. Portanto, devemos pensar de maneira ampla evitando os rótulos de muitos empreendimentos que consideram uma construção "verde" ou "ecológica", baseando-se apenas na adoção de algumas medidas isoladas. No sentido de verificar a qualidade do espaço urbano devemos avaliar os aspectos de acessibilidade, mobilidade, verde urbano, saneamento básico, conforto ambiental e a presença de áreas livres. Outro aspecto importante é a escolha adequada dos materiais e as técnicas adotadas que devem ser utilizadas conforme o clima do local para não importar soluções inadequadas. Neste contexto deve ser considerada a correta orientação solar no momento de elaboração do projeto, além de adaptar o projeto a topografia natural do terreno, preservar as árvores de espécies nativas, otimizar as condições de ventilação e iluminação natural e garantir o máximo de áreas permeáveis.

As ações necessárias para o alcance do desenvolvimento sustentável estão cada vez mais em evidencia no cenário nacional e internacional. No Brasil, a publicação da Lei $\mathrm{n}^{\circ} 6.938$ de agosto de 1981, constituiu um marco para as ações de conservação ambiental e incorporação do tema em atividades de diversos setores da sociedade. Esta 
lei tem como objetivo a preservação, melhoria e recuperação da qualidade ambiental propícia à vida atendendo os seguintes princípios:

\footnotetext{
"I - ação governamental na manutenção do equilíbrio ecológico, considerando o meio ambiente como um patrimônio público a ser necessariamente assegurado e protegido, tendo em vista o uso coletivo; II - racionalização do uso do solo, do subsolo, da água e do ar; Ill - planejamento e fiscalização do uso dos recursos ambientais; IV - proteção dos ecossistemas, com a preservação de áreas representativas; $\mathrm{V}$ - controle e zoneamento das atividades potencial ou efetivamente poluidoras;

VI - incentivos ao estudo e à pesquisa de tecnologias orientadas para o uso racional e a proteção dos recursos ambientais;

VII - acompanhamento do estado da qualidade ambiental;[...]" (LEI N ${ }^{\circ} 6.938$ de 31 de Agosto de 1981 p. 1)
}

Destacamos a Lei $n^{\circ} 10.257$ de 10 de julho de 2001, denominada Estatuto das Cidades, que estabeleceu diretrizes gerais para política urbana com vistas ao ordenamento para o desenvolvimento das funções sociais da cidade e da propriedade urbana, tendo como premissa o bem-estar dos cidadãos e equilíbrio ambiental. Neste cenário é fundamental aplicar e difundir o conhecimento de tecnologias disponíveis para o estudo e elaboração de projetos sustentáveis, com baixo consumo energético e confortável aos usuários.

\subsection{A SUSTENTABILIDADE NOS ESPAÇOS URBANOS}

Definir precisamente a arquitetura é algo difícil devido à amplitude e complexidade do tema. Para COSTA (1995), a arquitetura é a construção concebida com o propósito de ordenar e organizar o espaço para determinada finalidade e intenção (COSTA, 1995, p.246). Os espaços são dinâmicos e se transformam ao longo do tempo em virtude de necessidades econômicas e sociais do lugar.

MALARD (2005), descreve a arquitetura como o espaço de existência humana e está ligada a história, filosofia, arte e tecnologia. Afirma ainda que a arquitetura possui uma interface tecnológica que a edifica e torna habitável. Portanto, não podemos limitar a sua representação a apenas duas dimensões ortogonais das plantas baixas, cortes e fachadas. Os espaços devem ser planejados com ferramentas que possibilitem sua visualização holística ( MALARD,2005, p.77).

"Mas o espaço em si - a essência da arquitetura - transcende a quarta dimensão... A experiência espacial própria da arquitetura prolonga-se na cidade, nas ruas e praças, nos becos e parques, nos estádios e jardins, onde quer que a obra do homem haja limitado "vazios", isto é, tenha criado espaços fechados. Se no interior de um edifício o espaço é limitado por seis planos (por um soalho, um teto e quatro paredes), isto não significa que não seja igualmente espaço um vazio encerrado por cinco planos em vez de seis, como 
acontece num pátio ou numa praça. ...todo o espaço urbanístico, tudo o que é visualmente limitado por cortinas, quer seja muros, fileiras de árvores ou cenários, é caracterizado pelos mesmos elementos que distinguem o espaço arquitetônico" (Zevi, 1996, p. 25).

A arquitetura não se concentra apenas no edifício, ela ultrapassa os limites de suas paredes. O edifício possui uma pluralidade de valores e está inserido em um determinado contexto histórico, econômico cultural e social. A arquitetura inclui o conjunto de edifícios, ruas, praças, parques, o espaço de circulação que formam a malha urbana e o espaço de convivência, circulação, habitação, trabalho, lazer, em que passamos a maior parte de nossas vidas.

\footnotetext{
"Se pensarmos um pouco a respeito do fato do espaço, o vazio, ser o protagonista da arquitetura é, no fundo, natural, porque a arquitetura não é apenas arte nem só imagem de vida histórica ou de vida vivida por nós e pelos outros; é também, e sobretudo, o ambiente, a cena onde vivemos a nossa vida" (Zevi, 1996, p. 28).
}

Os espaços públicos urbanos podem ser definidos como aqueles espaços que são fundamentais e que frequentemente condicionam as edificações, e que às vezes lhes conferem suas formas, relevos e características. Esses locais são essenciais à paisagem urbana que constituem os espaços de vida, que "percebem" a cidade (ROMERO, 2001, p. 29).

O microclima dos espaços abertos é influenciado diretamente pela geometria urbana, vegetação, corpo d'água e propriedades térmicas dos materiais de construção. Os usos inadequados dessas variáveis contribuem para um ambiente desfavorável com temperaturas superiores ao ambiente interno, criando as chamadas "ilhas de calor". Em regiões tropicais onde predominam altas temperaturas quase o ano todo, os espaços públicos abertos devem ser sombreados possibilitando temperaturas amenas. $\mathrm{O}$ planejamento adequado do ambiente externo influencia diretamente no ambiente interno, sendo necessária também a realização de estudos de conforto térmico nos espaços urbanos.

Assim a concepção do espaço público deve ser atribuída uma forma definida que cria uma experiência de ambiente envolvente, articulado entre si e apto para o uso comum a que se destina. Deve ser um espaço pensado e construído com tanto planejamento e cuidado quanto a projeção de um edifício.

A qualidade ambiental dos espaços abertos depende do projeto urbano. $\mathrm{O}$ arquiteto-urbanista pode transformar uma área urbana em um espaço agradável ou desfavorável, resultando em um ambiente utilizado ou não pelas pessoas. Por essa 
razão, o clima local é determinante nas decisões de projeto. Assim, uma praça confortável em Paris provavelmente não o será no clima do Rio de Janeiro. Isto é devido ao fato de que em zonas tropicais não devemos expor as pessoas por um período prolongado de tempo à radiação solar, o que poderá causar desconforto térmico e visual (CORBELLA e YANNAS, 2003, p. 130 a 137).

O controle da luz natural nos espaços exige que se leve em consideração o efeito das edificações circunvizinhas. Essas edificações atingem sua maior influencia climática nas áreas densamente urbanizadas. No entanto, mesmo em áreas rurais as árvores podem provocar uma obstrução considerável que se traduz em uma redução na quantidade de luz natural disponível. As árvores de folhas caducas têm a vantagem de deixar cair suas folhas no inverno, permitindo um melhor acesso da luz natural durante os meses em que ela é mais escassa. Por outro lado, durante o verão, as folhas atuam como proteção em relação aos raios solares, tornando o ambiente mais agradável (HOPKINSON et al, 1966, p. 503).

Em projetos de áreas urbanizadas têm sido feitos esforços para evitar que os edifícios causem sérias obstruções uns aos outros durante o dia. Quando se projeta um conjunto novo de edifícios para um local pouco desenvolvido, a disposição de um edifício em relação a outro deve ser planejada para que todos recebam boa iluminação natural. Todavia, numa situação em que um edifício novo tenha que ser enquadrado em um conjunto já existente, ele deve ser planejado de modo que não cause obstruções que comprometa a iluminação dos edifícios vizinhos. (HOPKINSON et al, 1966, p. 503).

Podemos destacar o fato de que o uso de materiais que refletem a radiação em vez de absorvê-la, rapidamente devolvem ao exterior a parte que não foi absorvida, e permitem manter a temperatura baixa dentro do edifício. Contudo, essa utilização tornase um elemento pouco benéfico para o espaço externo circundante, uma vez que, além do calor incidente direto, o espaço retém a soma das emissões causando desconforto térmico e visual (ROMERO, 2001, p.83).

\subsection{O USO DA LUZ NATURAL NA ARQUITETURA}

O uso da luz natural (LN) sempre fez parte dos projetos arquitetônicos ao longo dos tempos. Segundo HOPKINSON (1966, p. 11) a luz é uma manifestação visual da energia radiante e, consequentemente, está intimamente relacionada com as sensações humanas. 


\begin{abstract}
"O homem é um ser totalmente dependente da luz, pois cerca de $70 \%$ da percepção humana é visual. Ela faz parte de sua vida do seu dia-a-dia, do seu modo de habitar. Desde que nasce, o homem está sendo submetido ao ritmo da natureza, da existência da noite e do dia, elementos que são condições necessárias para que ele se sinta pertencente ao próprio tempo"(VIANNA e GONÇALVES, 2001,p. 27).
\end{abstract}

A arquitetura clássica tratava a luz como se fosse algo precioso e ao mesmo tempo perigoso. O clima de altas temperaturas e com excesso de claridade proveniente do céu exigia uma arquitetura maciça e com pequenas aberturas. Assim, favorece um intermédio entre exterior extremamente luminoso e seu interior agradável com a luz controlada pela própria construção, nem quente nem frio. $\mathrm{O}$ urbanismo das cidades gregas, por meio de seu plano ortogonal, permitia o acesso da luz solar ao interior das casas para sua iluminação e calefação (VIANA, GONÇALVES , 2007).

As cidades do Império Romano foram herdeiras das características bioclimáticas das cidades gregas. Quanto aos edifícios, segundo CREMONINE (1962) antes do Panteão de Roma (118-125 d.C) não existia espaço interno criativo. O Panteão possui seu interior completamente fechado e iluminado no topo por uma cúpula. A abertura circular no topo é a única conexão com o mundo exterior. Vindo de ruas e ruelas vizinhas, ao entrar no Panteão sentimos uma perfeita expressão de paz e harmonia. A luz do sol que penetra na cúpula é difusa. Seus raios de luz provêm de uma altura muito elevada na mesma direção, pois provem de uma única fonte (o sol). O piso em mármore recebe grande quantidade de luz e boa parte dela é refletida, fazendo brilhar até os pontos mais escuros. O conceito arquitetônico da Rotunda do Panteão foi copiado várias vezes, porém com outras dimensões físicas (RASMUSSEN, 1986, p.10 ).
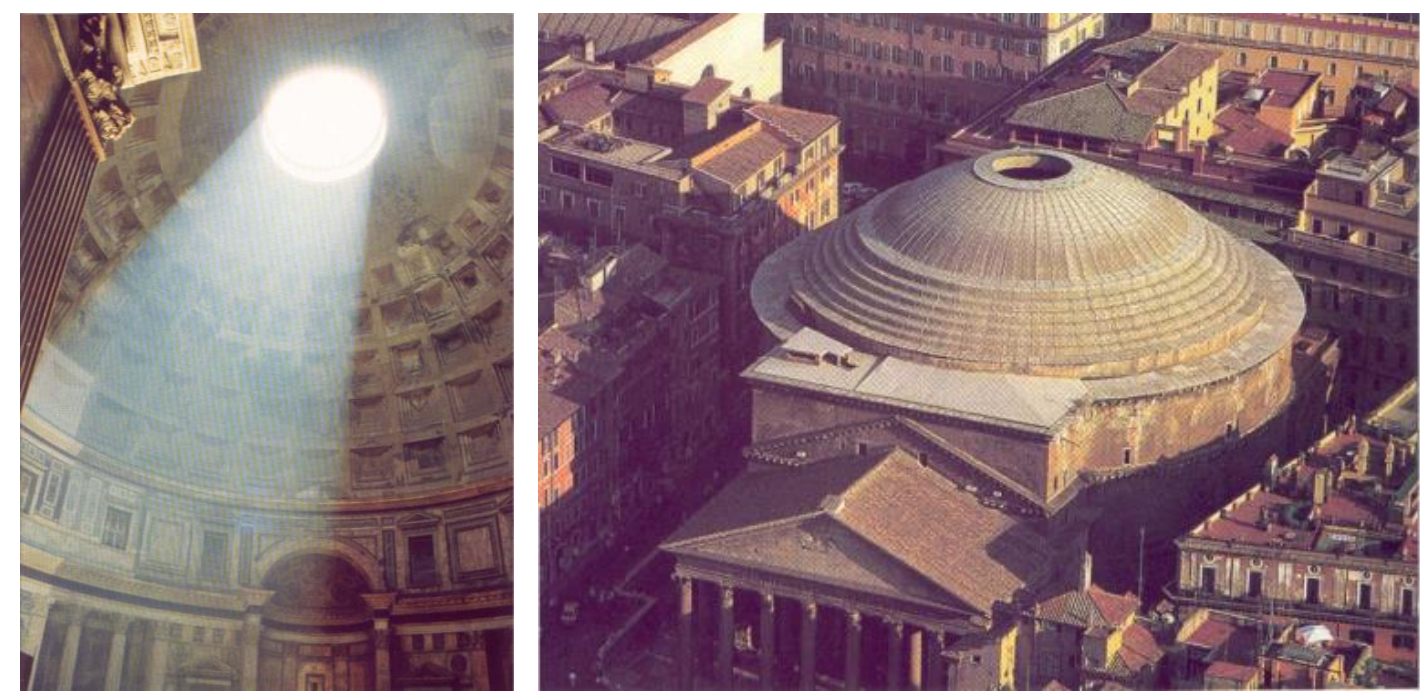

Figura 3: Panteão /Roma iluminação zenital Fonte: USP, 2008 
A prática da construção sustentável é de certa forma antiga. Se considerarmos as edificações de algumas culturas indígenas norte americanas, podemos perceber que eram adaptadas às condições locais, ao clima e à disponibilidade de materiais e recursos naturais do lugar onde foram inseridas. Poderíamos citar também os iglus construídos na Groelândia e no Ártico Central do Canadá, os quais foram feitos de materiais encontrados no sítio e construídos de forma a criar uma massa térmica e resistente aos ventos. As chamadas "teepee" foram construídas por povos nativos americanos e consistiam em uma tenda cônica usada pelos índios americanos como abrigo. Este tipo de tenda foi projetado para reter o calor no inverno, manter temperatura amena no verão e também para permanecer seca quando expostas à chuva. Sua construção era leve e, portanto fácil de ser transportada e reutilizada, feita de material de origem animal e vegetal encontrado na região (KRYGIEL e NIES, 2008, p. 6).

As aldeias dos índios brasileiros também eram construídas com uma relação de equilíbrio com o meio ambiente. Os aspectos naturais tinham grande importância nestas construções, pois todos os materiais utilizados na construção de aldeias e os utensílios eram retirados diretamente da natureza. O local era estrategicamente escolhido próximo à fonte de água potável e em áreas de caça e pesca abundante não sujeito a inundações. No Centro-Oeste, como na Amazônia as ocas geralmente não possuíam janelas, tal fato a principio pode causar estranheza, contudo ao observar o comportamento indígena podemos perceber que os índios não possuíam roupas nem cobertores para proteger do frio da madrugada com temperaturas entre 18 e 15 graus. Durante o dia o calor não ocasionava maiores problemas visto que grande parte das atividades aconteciam ao ar livre, além disto, estas ocas normalmente estavam perto de grandes florestas e cursos d'águas que amenizavam as temperaturas (GOUVÊA, 2002, p. 14).

Posteriormente nas áreas rurais e nas periferias do Brasil foram construídas as casas do caboclo que, como a oca indígena, eram adaptadas ao meio ambiente local. As casas eram construídas com barro e madeira/fibra técnica denominada "taipa de sopapo" e sempre tendo no seu entorno vegetação amenizando o clima seco do cerrado. Contudo os materiais variavam de acordo com a flora local, por exemplo, no Centro-Oeste as coberturas eram de folhas de buritis e outras palmeiras locais. Diferente das ocas estas casas possuíam janelas e portas assim como elemento de acesso, iluminação e ventilação, pois o caboclo desenvolvia uma serie de atividades domésticas no interior das casas (GOUVÊA, 2002, p. 20). 
A Revolução Industrial gerou a habilidade de produção em massa de peças desmontáveis que podem ser aproveitadas de forma mais rápidas e mais baratas do que as alternativas da mão de obra utilizadas no passado. Um dos benefícios da Revolução Industrial foi permitir o aumento da escala de produção de objetos necessários a sociedade. Naquele contexto ocorreu o início da pré-fabricação e da criação de componentes desmontáveis. Os recursos naturais utilizados para construir os modelos industriais foram raramente contabilizados no valor real. A maior parte dos recursos naturais foram tratados como produtos abundantes, sem limites e baratos (KRYGIEL e NIES, 2008, p. 03).

\begin{abstract}
"No início do século XX, a indústria da construção começou a dominar a fabricação de materiais e componentes pré-fabricados transportando esses materiais para vários países. Neste estágio, os edifícios ainda utilizavam a luz natural e a ventilação natural contendo janelas estreitas altas e controláveis. No entanto a invenção de tecnologias avançadas de iluminação elétrica, elevadores e outros sistemas mecânicos mudou a forma de construir os ambientes urbanos nas próximas décadas" (KRYGIEL e NIES, 2008, p. 05).
\end{abstract}

Devido ao desenvolvimento das tecnologias de aquecimento, ventilação e sistemas de ar a indústria da construção ao invés de projetar para um determinado clima, cultura e lugar começou a projetar de forma uniforme e padronizada para todos os tipos de situações. Como consequência desta evolução grande parte do aquecimento e resfriamento das edificações tornou-se mecânico e a maior parte da iluminação era artificial. Além disto, adquirimos materiais para construção, de qualquer parte do globo. Começando em meados do século XX até os dias atuais a humanidade está projetando sem considerar o clima e características locais (KRYGIEL e NIES, 2008, p. $05)$.

O uso da cortina de vidro foi introduzido pela Escola Bauhaus fundada na Alemanha na década de 30 . O uso das fachadas inteiramente envidraçadas criando a ideia de espaço aberto transparente tornou-se possível graças ao avanço da indústria do vidro e outras tecnologias como a luz fluorescente e os sistemas de ar condicionado. Esta nova tecnologia surgiu após o término da Segunda Guerra Mundial e tem como exemplo os trabalhos de Mies van de Rohe.

Mies utilizou as fachadas de vidro em vários trabalhos, de torres de escritórios e edifícios de residências, galerias de artes e pavilhões de exibição. Dentre os trabalhos deste arquiteto destaca-se o Seagram Building em Chicago, concluído em 1958. Este é um dos primeiros edifícios de torre de escritório a utilizar a cortina de vidro e a estrutura em esqueleto de ferro. O Seagram Building com 38 andares, é visto como a 
concretização da filosofia de Mies, de economia moderna, funcionalidade e pureza da forma, representando um ícone do século XX (VIANNA E GONÇALVES, 2001, p. 43).

O Lever House em Nova Iorque foi concluído em 1952. Projetado pelo escritório S.O.M - Skidmore Owings e Merrill, sendo um dos primeiro da linha de caixa de vidro que revolucionou a arquitetura dos edifícios altos.

Podemos citar ainda outro exemplo desta tipologia anterior ao próprio Seagram Building e Lever House na tecnologia da fachada envidraçada: o edifício do MEC no Rio de Janeiro de 1929. O projeto do edifício do MEC foi elaborado com a coordenação do arquiteto suíço Le Corbusier e projetado por Lúcio Costa com a participação de Oscar Niemeyer. Neste projeto foi executado o primeiro ensaio mundial de uma fachada não estrutural, inteiramente em vidro. Na fachada do edifício utilizou-se o brise-soleil como instrumento de proteção e controle da radiação e iluminação.
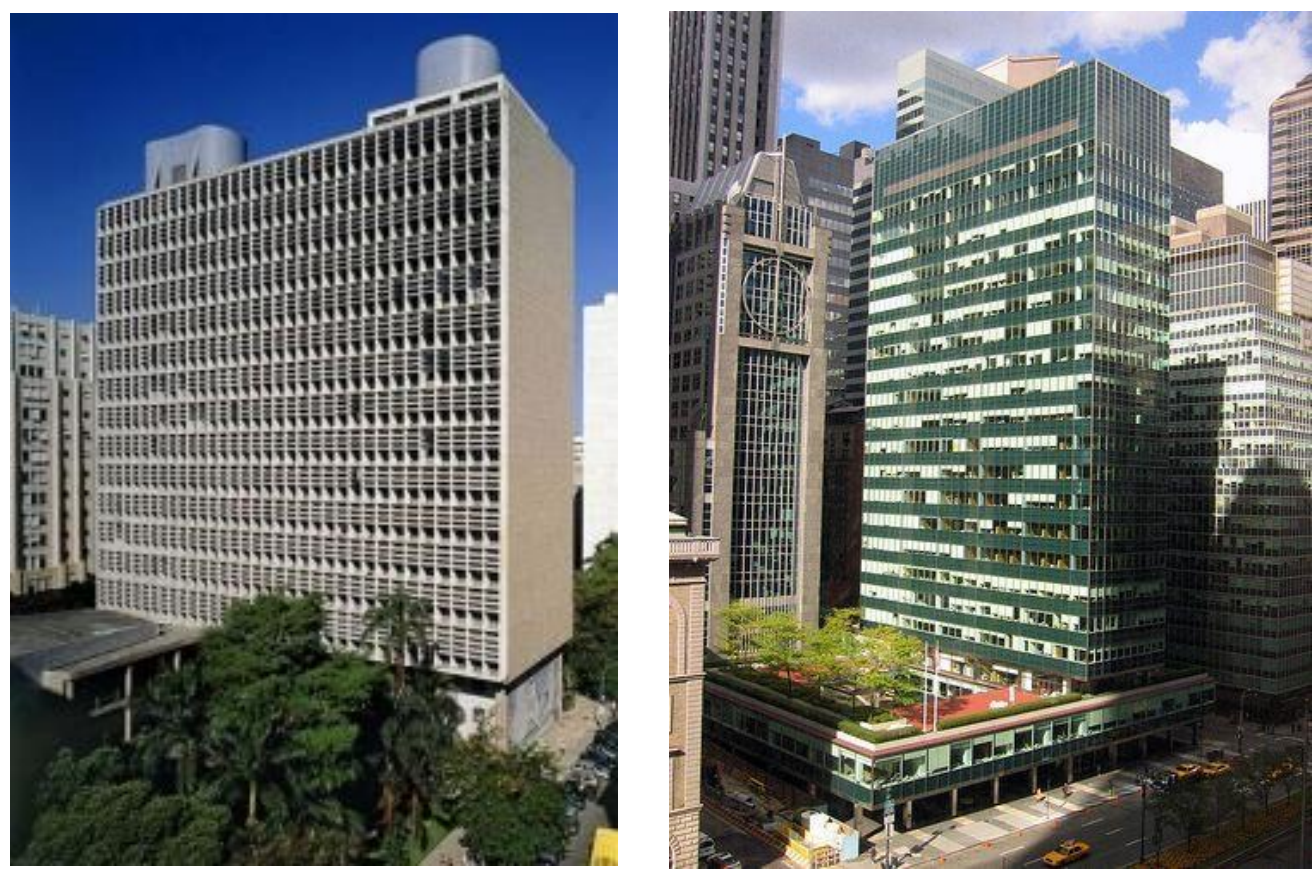

Figura 4: Edifício do MEC e Lever House

Fonte: http://www.vitruvius.com.br/revistas/read/minhacidade/08.086/1917

http://www.archdaily.com/61162/ad-classics-lever-house-skidmore-owings-merrill

Durante a história surgiram os mais distintos estilos arquitetônicos e tendências de acordo com a tecnologia da época. Na década de 50, difunde-se por vários países, o conceito de "pele de vidro" através do "estilo internacional" lançado pelo Movimento Moderno. As edificações nas cidades passaram a serem produzidas por uma arquitetura das caixas de vidro, indiferente ao meio externo e climatizadas por sistemas eletromecânicos (VIANNA E GONÇALVES, 2001, p. 45.). 
O uso e conhecimento da luz natural foram deixados em segundo plano devido à disponibilidade da energia elétrica e introdução de sistemas de iluminação mais eficientes como lâmpadas fluorescentes. Ao mesmo tempo em que as novas tecnologias atendiam a uma demanda por níveis maiores de iluminância, a qualidade da luz recebia menos atenção.

No entanto, nos últimos anos em virtude da crise energética e mudanças climáticas, tem havido uma procura por uma arquitetura sustentável que se baseia no conceito de qualidade ambiental através do aproveitamento racional dos recursos da natureza. Desta forma este conceito tornou-se requisito indispensável no processo construtivo contemporâneo. O uso adequado da luz natural representa uma grande vantagem na qualidade ambiental, pois interfere tanto no conforto visual como térmico. A arquitetura de grandes panos de vidro começou a ser questionada principalmente em países com clima tropical, pois produz problemas de ofuscamento e ganhos térmicos.

\footnotetext{
“Ao projetar o espaço arquitetônico considerando a LN temos que considerar também outros aspectos relacionados a ela, como a carga térmica recebida nos ambientes. A disponibilidade da LN nas regiões tropicais é grande, e esta deve ser usada de forma criteriosa, equilibrando sabiamente o ingresso da luz difusa, bloqueando o calor gerado pela luz solar direta, que pode criar problemas de conforto térmico e luminoso. A eficiência luminosa da LN é maior que quase todas as (outras) fontes; isto significa que mesmo a luz natural direta, se bem distribuída, é mais eficiente, e gera menos calor que a luz artificial" (AMORIM, 2002 apud. CHRISTAKOU, 2004, p. 4).
}

O progresso tecnológico com a afirmação do High-tec surgido na década de 60 evoluiu para uma abordagem e preocupações com aspectos de entorno, consciência social, economia de energia, urbanidade e consciência ecológica, sendo chamado de movimento Eco-tec. Neste cenário destacam-se os nomes de Richard Roger, Nicholas Grimshaw, Michael Hopkins, Norman Foster, entre outros (VIANNA E GONÇALVES, 2001, p. 46).

A simulação computacional ambiental é realizada com o objetivo de minimizar os impactos das construções sobre o meio ambiente. As transformações que ocorreram nas cidades vinculadas à degradação ambiental nos mostram necessidades de criar meios adequados para a construção e projetação consciente quanto aos impactos ambientais ocasionados. Neste contexto, os softwares de simulação ambiental foram criados com o objetivo facilitar a análise e tomada de decisão no processo de projetação, além de possibilitar os estudos do impacto ambiental em edificações existentes. 


\subsection{EXEMPLOS DE USO INADEQUADOS DA LUZ NATURAL EM EDIFICAÇÕES}

O edifício localizado em Londres na 20 Fenchurch Street, apelidado de "Walkie Talkie" devido ao seu formato, foi concebido pelo escritório do arquiteto uruguaio Rafael Viñoly. Tornou-se conhecido não por sua arquitetura, mas pelo reflexo de luz solar da sua fachada no espaço circundante. A fachada de vidro espelhado e côncavo do edifício reflete os raios solares que convergem em alguns pontos da cidade concentrando a luz solar e ocasionando grande aumento de temperatura. Uma temperatura de $91.3^{\circ} \mathrm{C}$ foi constatada ao nível da rua em Eastcheap.

A edificação de 37 andares e 160 metros de altura, ao refletir a luz natural aquece pontos do entorno do edifício de tal forma que derreteu a carroçaria de um automóvel, incendiou tapetes, danificou fachadas de edifícios vizinhos e ocasionou grande desconforto aos pedestres em virtude do aquecimento e ofuscamento causado.

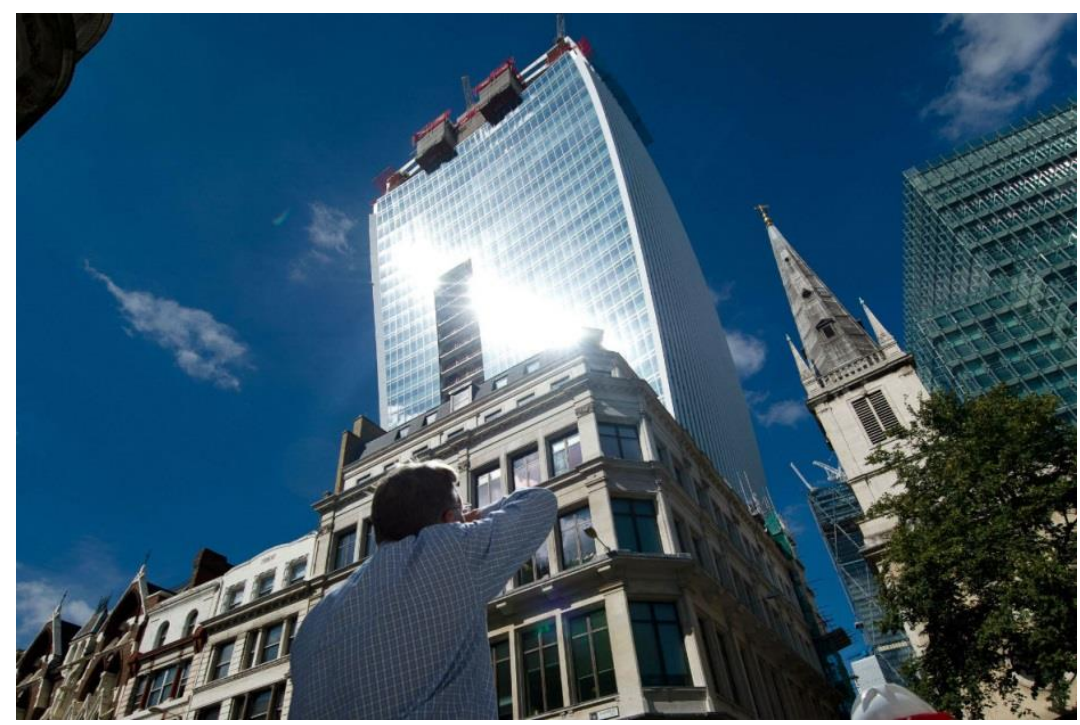

Figura 5: Edificio "Walkie Talkie" Fonte: http://www.archdaily.com.br/br/tag/walkie-talkie

$\mathrm{O}$ arquiteto responsável pela elaboração do projeto em uma entrevista ao Guardian informou que: "sabia que isto podia acontecer, mas contrapôs que não contou com as ferramentas ou com o software necessários para analisar com precisão o problema e a localização do edificio...”. (http://www.publico.pt/mundo/noticia/ arquitecto-nao-pensou-que-luz-reflectida-em-predio-de-londres-derretesse-coisas1605184 acessado em 28/09/2015).

Antes de solucionar o problema foi montada uma estrutura de andaimes que proibiu o estacionamento em três zonas da área circundante ao projeto. A construtora Land Securities, responsável pela construção do arranha-céu se comprometeu a ressarcir 
os consertos necessários, assim como a avaliar seu projeto arquitetônico para solucionar estes problemas. Como solução paliativa foi instalada uma tela de lona para cobrir o arranha-céu de Londres evitando a refletância dos raios solares de suas vidraças.

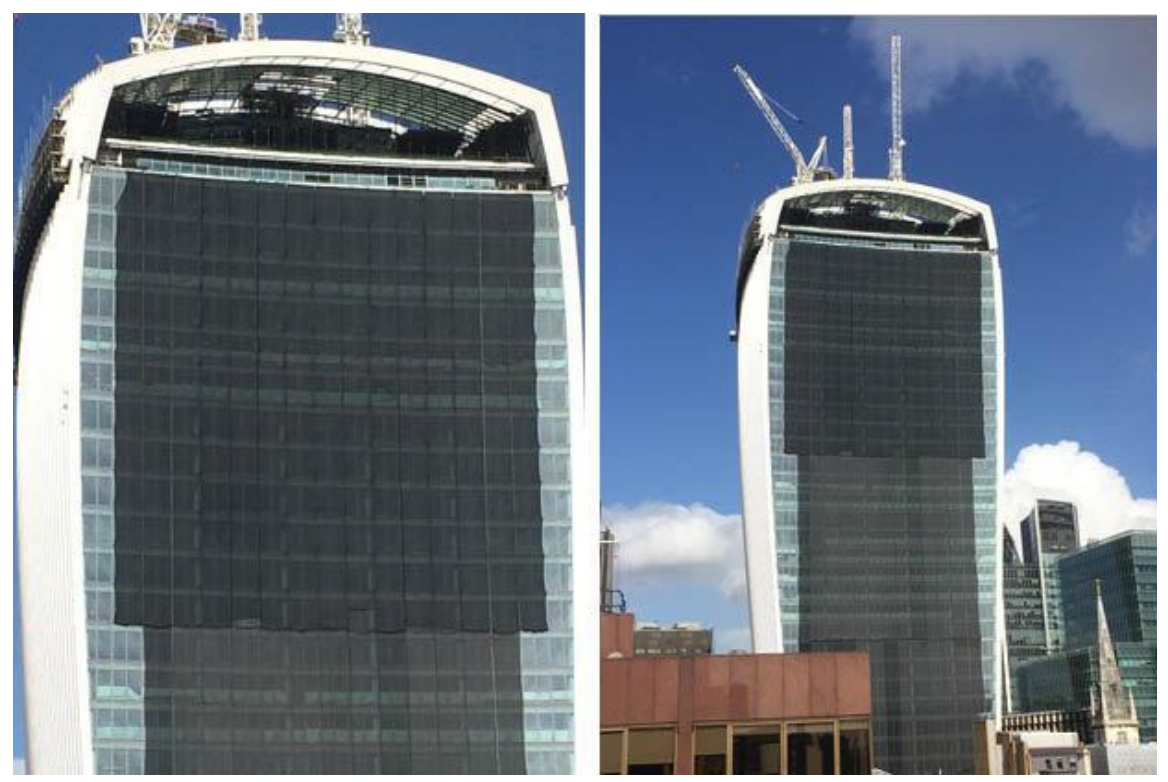

Figura 6: Instalação de tela no edificio "Walkie Talkie" Fonte: http://www.archdaily.com.br/br/tag/walkie-talkie

O arquiteto Rafael Vinoly é responsável também pelo projeto do Hotel Vdara em Las Vegas que enfrentou o mesmo problema devido ao seu formato côncavo e fachada espelhada. Este edifício é responsável por elevadas temperaturas e ofuscamento em áreas circundantes, chegando inclusive a derreter copos e mobiliário de plástico e queimar hospedes na área de lazer do hotel. 


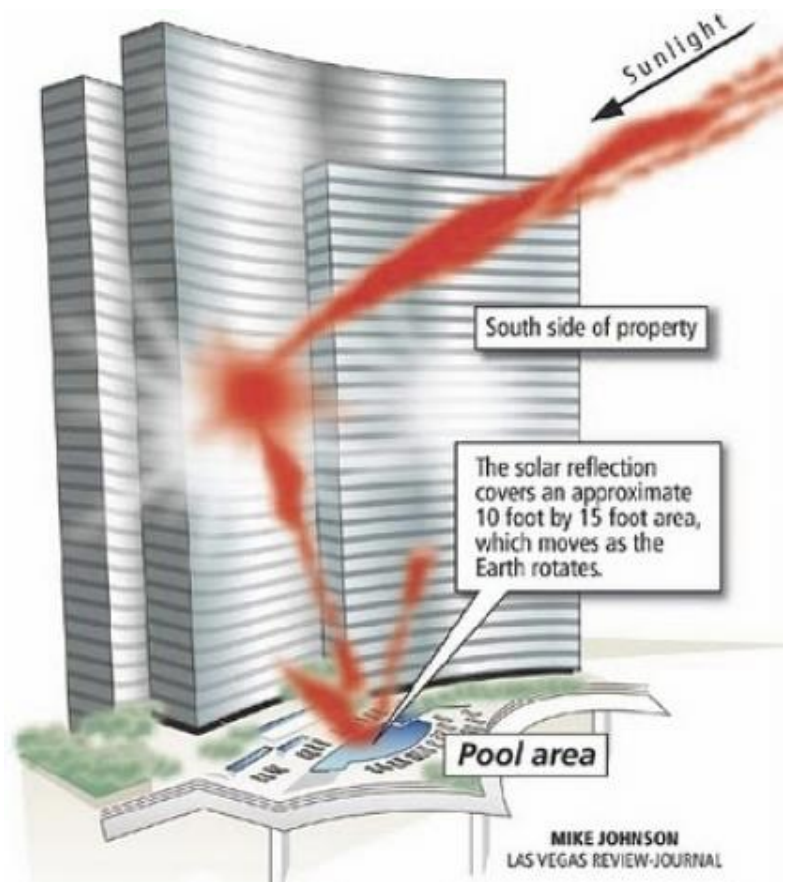

Figura 7: Hotel Vdara

Fonte:http://economia.estadao.com.br/noticias/geral,arquiteto-do-predio-que-dispara-raios-decalor-e-reincidente, $163805 \mathrm{e}$

O Walt Disney Concert Hall, localizado na cidade de Los Angeles nos Estados Unidos, projetado por Frank Gehry, enfrentou problema similar de refletância devido ao formato e revestimento externo das fachadas em aço. O edifício é coberto por painéis de aço que refletem os raios solares nas calçadas e entorno ocasionando aumento de temperatura, além de brilho ofuscante que afeta motoristas e pedestres.

O ofuscamento urbano das edificações pode ser provocado pela forma, localização, material utilizado no revestimento da fachada e pela orientação do edifício. Isto implica em desconforto e comprometimento da segurança no ambiente externo além de aumento da carga térmica e consumo de energia de edifícios afetados. A luz natural refletida por meio de pele envoltória de uma edificação pode diminuir os ganhos térmicos internos, porém pode gerar aquecimento da superfície urbana e em alguns casos ofuscamento no espaço externo ao edifício. Portanto, o impacto das superfícies refletivas deve ser avaliado no planejamento do espaço urbano e no projeto de edifícios com objetivo de permitir o conforto visual e consequentemente térmico interno e externo a edificação.

Devemos considerar que um dos papéis do arquiteto(a) é enriquecer o cotidiano da vida urbana, construindo espaços com qualidade ambiental, revelado por meio da luz. Ao desenvolver projetos de edificações podemos elaborar uma arquitetura inovadora com interações entre relações espaciais e tecnologia de ponta, consciente das 
paredes de vidro, comunicando interior e exterior com maior sutileza. Devemos também considerar o uso adequado da luz natural em todo o projeto inclusive áreas centrais e externas ao edifício.

Os citados erros de projeto poderiam ter sido evitados se tivesse sido feita a análise da luz natural no processo de projetação, por meio do uso de softwares específicos para o cálculo da luz natural.

\subsection{ASPECTOS DA LUZ NATURAL}

A radiação solar para chegar até a superfície da terra tem que passar pela atmosfera. Ao chegar até ela, a intensidade dessa energia se vê diluída, devido a larga distancia percorrida e também pela influência de fatores como umidade, ozônio, poluição e poeira no ar, que são uma espécie de obstáculo na atmosfera para a chegada da radiação até a superfície. Portanto a porcentagem da radiação que chega até a superfície de um determinado lugar varia segundo a localização geográfica (latitude), a altitude e o clima (HERTZ, 1998, p.13).

A LN que ilumina os ambientes é constituída basicamente por três componentes: a luz direta do sol, luz difusa do céu e a luz refletida pelo solo e outras superfícies do entorno. (VIANA e GONÇALVES, 2004 apud. CHRISTAKOU, 2004, p. 26).

Todos estes elementos se somam constituindo a iluminação diurna ou natural, característica de cada região. Essa luz diurna varia em quantidade - visto que a iluminação natural pode oscilar entre algumas centenas de lux à sombra e até cem mil lux em pleno sol - e varia também em qualidade, sendo a reprodução da cor um bom aspecto para exemplificar o tema (MASCARÓ, 1979, p. 35).

"A energia radiante visível mede-se pelo ritmo de transferência de energia avaliada em termos do seu efeito sobre o sentido visual humano médio. Este fluxo luminoso exprime-se em lumens. A distribuição de luz sobre uma superfície exprime-se em termo de lúmens por unidade de área e dá-se a designação de iluminação" ( Hopkinson et al, 1966, p.11).

É importante lembrar que os raios luminosos não são visíveis, a sensação de luminosidade é decorrente da reflexão desses raios por uma superfície. Essa luminosidade vista é chamada de luminância. Os objetos possuem diferentes capacidades de reflexão da luz, portanto, uma certa iluminância pode gerar diferentes luminâncias .

O coeficiente de reflexão é a relação entre o fluxo luminoso incidente e o refletido pela superfície. Esse coeficiente varia de acordo com as características 
refletoras da superfície. Se uma luz incidir sobre uma superfície negra com um poder de reflexão nulo, nada se verá dessa superfície. Já o brilho máximo, isto é, o máximo efeito visual, resultará da reflexão a partir de uma superfície com um poder de reflexão máximo. Neste sentido se faz necessário apresentar os seguintes conceitos:

Iluminância - luz incidente, não visível (lúmen por metro quadrado =1 lux);

Luminância - luz refletida, visível (candela por metro quadrado = 1 nit);

Candela - "unidade de intensidade luminosa" (Hopkinson et al, 1966, p.705);

Lúmen - "fluxo luminoso emitido por uma fonte pontual com intensidade luminosa uniforme de 1 candela sob um ângulo sólido unitário" (Hopkinson et al, 1966, p.705).

O brilho físico de um objeto, medido por um fotômetro, não é o mesmo que o brilho subjetivo desse mesmo objeto visto pelos olhos adaptados ao ambiente. A palavra luminância emprega-se para especificar a quantidade física do brilho.

Apesar de um brilho intenso ser um dos fatores que mais aperfeiçoe a visão, um brilho intenso indesejável pode igualmente ser a causa de diminuição, tanto da acuidade visual como da sensibilidade ao contraste. Os olhos veem melhor um objeto quando o mesmo é mais brilhante que o campo visual, sendo pior a visão quando os objetos estranhos são mais brilhantes do que a tarefa visual essencial.

\footnotetext{
"Contraste é definido como a diferença entre a luminância (brilho) de um objeto e a luminância do entorno imediato desse objeto. Em pleno dia podemos perceber diferenças de luminâncias de até $1 \%$, mas sob condições precárias de iluminação até diferenças de $10 \%$ podem passar despercebidas. A sensibilidade ao contrate melhora com o aumento da luminância, que por sua vez é função da iluminação, até certos limites (possibilidade de ocorrer ofuscamento) "(LAMBERTS et al, 1997 p.46).
}

Segundo CHRISTAKOU apud SERRA (2004, p.28), a ausência de sensações de dor, irritação e distração dependem dos níveis de contraste e das variações das luminâncias no interior do edifício. Assim, o ofuscamento é o maior responsável pelo desconforto visual. Este parâmetro de desconforto é o efeito desagradável causado por excessivo contraste das luminâncias no campo visual.

Existem dois tipos de ofuscamento, o velamento e o adaptativo. $\mathrm{O}$ velamento é produzido por um foco brilhante em um fundo mais escuro; assim os raios de luz entram na retina causando um grau de difusão que nos faz ver o foco brilhante como se estivesse envolvido em um véu, ou produzindo raios em forma de estrela. Já o ofuscamento adaptativo tem sua causa na incapacidade de adaptação do olho humano de 
não admitir variações extremas de luminâncias no campo visual e é o mais importante para arquitetura.

Dois aspectos da LN são igualmente importantes. O primeiro consiste em garantir uma iluminação suficiente para que se possa trabalhar com eficiência rapidez e precisão. O segundo consiste em proporcionar um ambiente visual agradável, o que depende da distribuição equilibrada da LN no ambiente. Estes aspectos não são incompatíveis, mas muitas vezes quando tentamos satisfazer um deles, o outro, que é freqüientemente o aspecto qualitativo, é ignorado.

O estabelecimento de uma luz adequada para um trabalho visualmente eficiente é o primeiro requisito para um projeto de iluminação. Quando o critério quantitativo é assegurado apenas pelo encadeamento excessivo luz, o resultado não será considerado satisfatório ocasionando o desconforto visual (HOPKINSON et al, 1966, p. 4).

A Luz Natural (LN) oferece inúmeras vantagens, entre as quais podemos citar:

-A qualidade da iluminação obtida é melhor, pois a visão humana desenvolveuse com a LN;

-A constante mudança da quantidade de LN é favorável, pois proporciona efeitos estimulantes nos ambientes;

-A LN é fornecida por fonte de energia renovável, é o uso mais evidente da energia solar.

Considerando que um dos principais focos da arquitetura é proporcionar conforto aos usuários, é fundamental o uso adequado da LN em projetos arquitetônicos e urbanísticos (MAJOROS,1998 apud AMORIM, 2002, p.2).

\section{6 - AVALIAÇÃO DA LUZ NATURAL EM PROJETOS ARQUITETÔNICOS}

A avaliação ambiental de espaços arquitetônicos é considerada uma necessidade de projeto porque permite o controle de suas variáveis climáticas tais como temperatura, iluminação, ventilação. Antes do advento da simulação computacional ambiental a avaliação da Luz Natural em projetos arquitetônicos poderia ser estudada de duas maneiras distintas através de ferramentas de cálculo simplificado e simulação com modelo em escala reduzida.

As ferramentas utilizadas na avaliação ambiental de cálculos simplificados podem ser subdivididas de acordo com o método: matemático, tabular, e gráfico (AMORIM, 2006, p. 2). 
Os métodos matemáticos são procedimentos de cálculo desenvolvidos através de equações baseadas nas hipóteses físicas, parâmetros geométricos e procedimentos analíticos. São úteis e relativamente simples para um único ponto, porém são lentos e trabalhosos para vários pontos de análise.

O método tabular consiste na avaliação comparativa do fator de luz natural ou do componente de céu através de uma série de parâmetros geométricos (AMORIM, 2006, p. 2).

Por sua vez, os métodos gráficos, bastante utilizados nas fases iniciais do projeto, são baseados no uso de gráficos como os diagramas de ponto, carta solar, os transferidores, os diagramas Waldram, entre outros. São de fácil aplicação e exibição do efeito relativo de diversas variáveis de projeto, porém esse método analisa um único ponto de cada vez (BAKER e STEEMERS ,1998 apud SILVA e CHRISTAKOU 2007, p. 50).

Existem duas formas de simular a iluminação natural em Modelos Físicos de Escala Reduzida (maquete): o uso do céu real, que é mais barato e fácil, essa avaliação implica em condições de estudo de muitas variáveis e de pouco controle; e o uso de céu artificial, onde as condições são estáveis, tendo a limitação de ser usado somente para estudo sob céu encoberto e de tamanho finito (MOORE, 1985 apud SILVA, CHRISTAKOU, 2007, p. 49).

A escala da maquete deve ser coerente com o tamanho da fotocélula de medição. Modelos muito reduzidos não são aconselháveis para este tipo de avaliação, normalmente é utilizada a escala de 1:25.

As limitações desse tipo de simulação são: o fato de que a construção de maquetes de forma manual demanda muito tempo, requer precisão na geometria das obstruções e a possibilidade de haver interferências causadas pelo observador ou câmara no nível luminoso resultante. Outras limitações ocorrem em relação aos estudos paramétricos comparativos e a necessidade de boa instrumentação fotométrica. (MOORE, 1985 apud SILVA e CHRISTAKOU, 2007, p. 50).

O termo "simulação computacional" é referente a qualquer algoritmo que mimetiza um processo físico. Quando o ambiente projetado é simulado no computador pode-se obter dados da temperatura, iluminação natural, ventilação, entre outros, através de imagens e gráficos que permitem analisar a interação entre os aspectos de projeto, o conforto ambiental e a eficiência energética. 
Segundo SILVA e CRISTAKOU o estudo da iluminação nos projetos de arquitetura e urbanismo deve ser desenvolvido ainda na fase de concepção da proposta projetual, visto que, grande parte das variáveis relacionadas ao uso da luz natural nos ambientes, tais como, orientação, posicionamento, tamanho e orientação das aberturas são definidas ainda nessa fase (SILVA e CRISTAKOU, 2007, p. 48).

A garantia da correta avaliação ambiental do espaço a ser projetado depende da capacidade de modelagem destes simuladores e da interoperabilidade entre os softwares. Com o surgimento e evolução de novas tecnologias a arquitetura contemporânea tem sido produzida com recursos computacionais que permitem construir formas ousadas e complexas compostas por geometrias não- Euclidianas. Portanto é fundamental que os simuladores ambientais acompanhem esta nova tecnologia de modelagem de formas não lineares com o objetivo de avaliar aspectos ambientais das edificações e espaços urbanos para auxiliar a tomada de decisões do partido arquitetônico.

É necessário que haja maior divulgação e estudo desta tecnologia para o conhecimento de suas especificidades visto os benefícios que podem ser agregados aos projetos. Estes estudos possibilitam a construção com menor impacto ambiental e utilização de recursos disponíveis como a luz natural, de forma adequada e com diminuição do consumo energético.

\subsection{CONTEXTO DA ARQUITETURA DIGITAL}

"O Palácio de Cristal de Joseph Paxton era uma construção audaciosa para seu tempo incorporando o espírito tecnológico da revolução industrial e constituindo-se um sinal de um futuro das construções em aço e vidro. A Torre Eiffel manifestou as alturas elevadas que os novos edifícios poderiam alcançar. Contudo, demorou mais cem anos para que os prédios altos e brilhosos de vidro e aço se tornassem uma presença frequente no mundo inteiro e dominassem o horizonte de cada metrópole urbana" (KOLAREVIC, 2003, p.03).

O Palácio de Cristal construído em 1851 na cidade de Londres para a primeira exposição mundial tinha como módulo base uma chapa de vidro da maior dimensão que era permitido produzir com a tecnologia disponível. Todos os elementos construtivos eram normatizados e pré-fabricados industrialmente, o edifício de $70.000 \mathrm{~m}^{2}$ foi montado em menos de cinco meses sendo um grande avanço para época. O Palácio de Cristal teve inúmeros sucessores e constituiu um início para uma nova forma de construir sem ornamento e com ferro e vidro. 

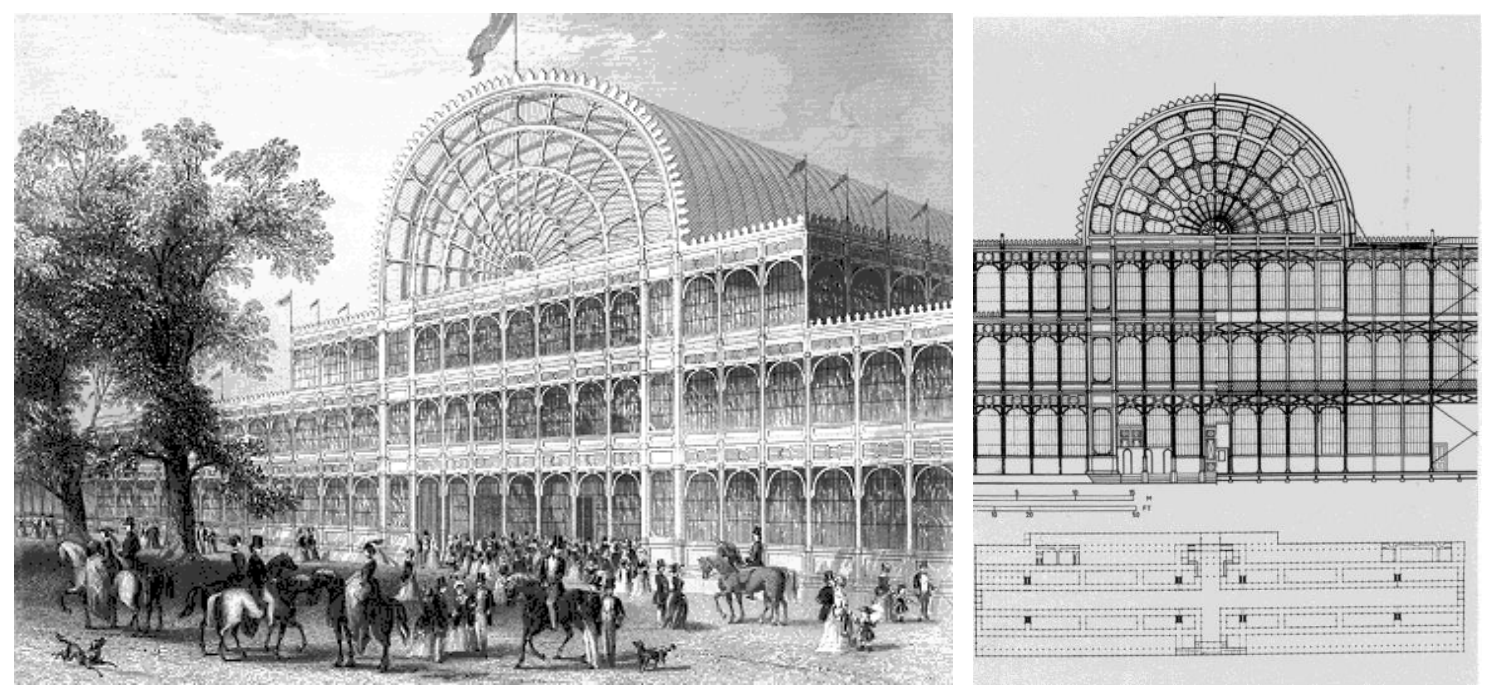

Figura 8: Palácio de Cristal

Fonte: https://en.wikipedia.org/wiki/The_Crystal_Palace acessado em 02/10/2015

Posterior ao Palácio de Cristal, a Torre Eiffel é considerada outro paradigma de modernidade que foi construída em Paris no ano de 1889 e considerada o símbolo da arquitetura de ferro e mais tarde o marco da cidade de Paris. Durante quarenta anos foi a estrutura mais alta do mundo com trezentos metros de altura. Aquela altura foi atingida com auxílio de treliças de ferro pré-fabricadas que oferecem uma resistência máxima com peso mínimo e sua forma expõe a distribuição dos esforços.

A tecnologia utilizada para a construção do Palácio de Cristal e Torre Eiffel pode ser comparada ao CAD/CAM- Projeto Assistido por Computador/ Fabricação Assistida por Computador (Computer Aided Design/ Computer Aided Manufacturing). Hoje com as construções de arranha-céus em vidro é muito difícil imaginar o significado revolucionário atribuído pelos seus contemporâneos a estes edifícios totalmente inovadores. A construção destes edifícios para exposições, em ferro e vidro antevia a evolução que conduziria a arquitetura posterior.

"Apenas nos últimos anos as tecnologias de projeto assistido por computador
(CAD) assim como fabricação assistida por computador (CAM) começaram
a mostrar resultados no desenho arquitetônico e na construção. Estas
tecnologias abriram novas oportunidades para produção e construção de
formas complexas que até pouco tempo eram muito difíceis e caras de serem
executadas utilizando metodologia e experiências tradicionais"
(KOLAREVIC, 2003, p. 3).

A arquitetura contemporânea a partir da década de 1990 é influenciada por essa nova forma de projetação e construção. A tecnologia CAD/CAM foi utilizada primeiramente nas indústrias naval, aeronáutica e automobilística. Na construção, a relação direta da tecnologia CAD e a fabricação digital com o uso de CAM associado a tecnologia $\mathrm{CNC}$ permite ampliar as possibilidades projetuais e construtivas. $\mathrm{O}$ resultado 
é a facilidade de construção de geometrias não-Euclidianas a partir de um modelo tridimensional criado digitalmente que é enviado diretamente para a maquina de CNC para fabricação dos componentes construtivos. Assim os componentes irregulares das edificações podem ser fabricados com custos semelhantes ou até inferiores aos produzidos em série (MORAIS, 2010, p.29).

Esta tecnologia é uma nova opção construtiva que possibilita a liberdade criativa e introdução de um novo vocabulário de formas na arquitetura facilitando a precisão, rapidez e eficiência do projeto.

Os recursos da tecnologia CAD/CAM têm contribuído para que o arquiteto ultrapasse as limitações impostas pela padronização que ainda domina a indústria da construção. As tecnologias disponíveis resultantes da revolução digital, como softwares de modelagem tridimensionais, afetam diretamente a produção arquitetônica, pois possibilitaram a construção de formas curvas de alta complexidade que estão sendo incorporadas como principal tendência da arquitetura digital.

\begin{abstract}
"Uma mudança dramática que ninguém poderia supor a apenas uma década atrás: em termos conceituais, a arquitetura concebida digitalmente a partir de um espaço geométrico não Euclidiano, sistemas cinéticos e dinâmicos e algoritmos gerativos de formas está superando os padrões arquitetônicos tradicionais, auxiliada pela incorporação dos avanços já ocorridos na indústria automobilística, aeroespacial e navegação. Em especial, a possibilidade de integração dos sistemas CAD com os sistemas CAM, que têm permitindo a produção e construção de formas altamente complexas que até pouco tempo atrás eram praticamente inviáveis, em termos de custo e produção" (NARDELLI, 2007, p.30).
\end{abstract}

Os primeiros softwares desenvolvidos para o projeto de arquitetura privilegiavam formas convencionais. Mas com o avanço de softwares utilizados na indústria automobilística, naval e aeroespacial na elaboração de formas complexas, viabilizou a construção de superfícies curvas também na arquitetura. A fabricação dessas formas para ser realizada com sucesso requer máquinas que consigam traduzir eficientemente a representação digital do objeto projetado, ampliando as possibilidades formais o que torna possível grande liberdade criativa. Os benefícios para a projetação e construção de formas ousadas são provenientes do uso das ferramentas como a modelagem computacional tridimensional a prototipagem rápida (RP- Rapid Prototyping) e o uso da tecnologia de controle numérico por computador- CNC (Computer Numerical Control) para a fabricação digital em ambiente industrial por meio das tecnologias CAM (Computer-Aided Manufacturing).

“ O computador abriu novos horizontes que não são forçosamente aqueles que imaginávamos originalmente. Usando, como partida, por alguns como 
uma forma de visualização de estruturas cada vez mais extravagantes, a tecnologia digital aproxima-se rapidamente de uma espécie de maturidade que tem um efeito muito mais profundo e duradouro na arquitetura(...). A nova liberdade sugerida pelo computador é capaz de desembaraçar a arquitetura da sua caixa Euclidiana" (JODIDIO,2008 apud MORAIS,2010, p.15)

As construções de formas ousadas que utilizam a tecnologia CAD/CAM para sua execução podem ser consideradas um novo paradigma da arquitetura contemporânea. A era digital mudou radicalmente a relação entre concepção e produção, os projetos atualmente não são apenas concebidos digitalmente, mas também construídos digitalmente. A maioria dos arquitetos que tiveram destaque internacionalmente utilizou essa tecnologia em seus projetos que é considerada a nova tendência da arquitetura internacional.

"Diante dessa evolução contínua e inevitável e dos programas que surgem, criados pela vida e pelo progresso, o arquiteto vem concebendo, através dos tempos, o seu projeto: frio e monótono ou belo e criador, conforme seu temperamento e sensibilidade" (Niemeyer, 2005, p.18).

O desenvolvimento de geometrias diferenciadas está diretamente ligado aos avanços da matemática, da computação e dos programas CAD. Devido a introdução das curvas NURBS (Non Uniform Rational B-Splines), tornou-se possível manipular os pontos destas curvas, dessa forma ajustando a forma global das mesmas. As curvas NURBS são definidas através de fórmulas matemáticas, o que significa que quando se altera um parâmetro da curva a forma geral é recalculada e re-configurada.

"Esta nova arquitetura digital está emergindo como resultado da revolução digital. Projetos que encontram sua expressão em formas altamente complexas e curvilíneas estão gradualmente se inserindo na prática da arquitetura. Contudo não existe uma forma dominante e monolítica entre os "avant-garde" da arquitetura digital. A força unificadora entre os desenhistas e pensadores na área digital não é o desejo de projetar formas amebóides ("blobify"), mas de usar a tecnologia digital como um aparelho capaz de integrar concepção e produção de modo que não existem antecedentes desde os tempos medievais dos mestres construtores" (KOLAREVIC, 2003, p. 4).

Estes avanços tecnológicos e a possibilidade de criação de formas ousadas vêm alterando o processo e as ferramentas disponíveis na arquitetura e construção, constituindo-se, assim, um novo paradigma. A evolução dos Sistemas CAD na direção da modelagem e manipulação de superfícies complexas, associada às novas exigências funcionais e estéticas, impulsionou a inserção cada vez maior da representação de superfícies complexas na arquitetura.

"O primeiro Palácio de Cristal e Torre Eiffel da nova revolução da informação foram construídos durante os últimos anos. $O$ Museu Guggenheim de Bilbao de Frank Gehry é provavelmente o melhor exemplo 
de representação do espírito da época da revolução digital da informação, cujas consequências para indústria da construção representa escala semelhante àquela da revolução industrial. A revolução da informação assim como a revolução industrial está desafiando não apenas como nós projetamos as edificações mas também como os fabricamos e construímos" (KOLAREVIC, 2003, p.03).

O Museu Guggenheim de Frank Gehry, em Bilbao, é considerado a síntese evidente e reconhecida de uma nova maneira de pensar a forma, buscando novos métodos de projetar, por meio da tecnologia digital. As tecnologias digitais libertaram a imagem dos tradicionais conceitos de representação, as formas não estão mais sendo representadas de um modo convencional baseado nos parâmetros de um espaço estático. Novos conceitos de espaço baseados em formas dinâmicas e interativas que produzem novas categorias de projetos que se viabilizam através das Tecnologias da Informação e Comunicação.

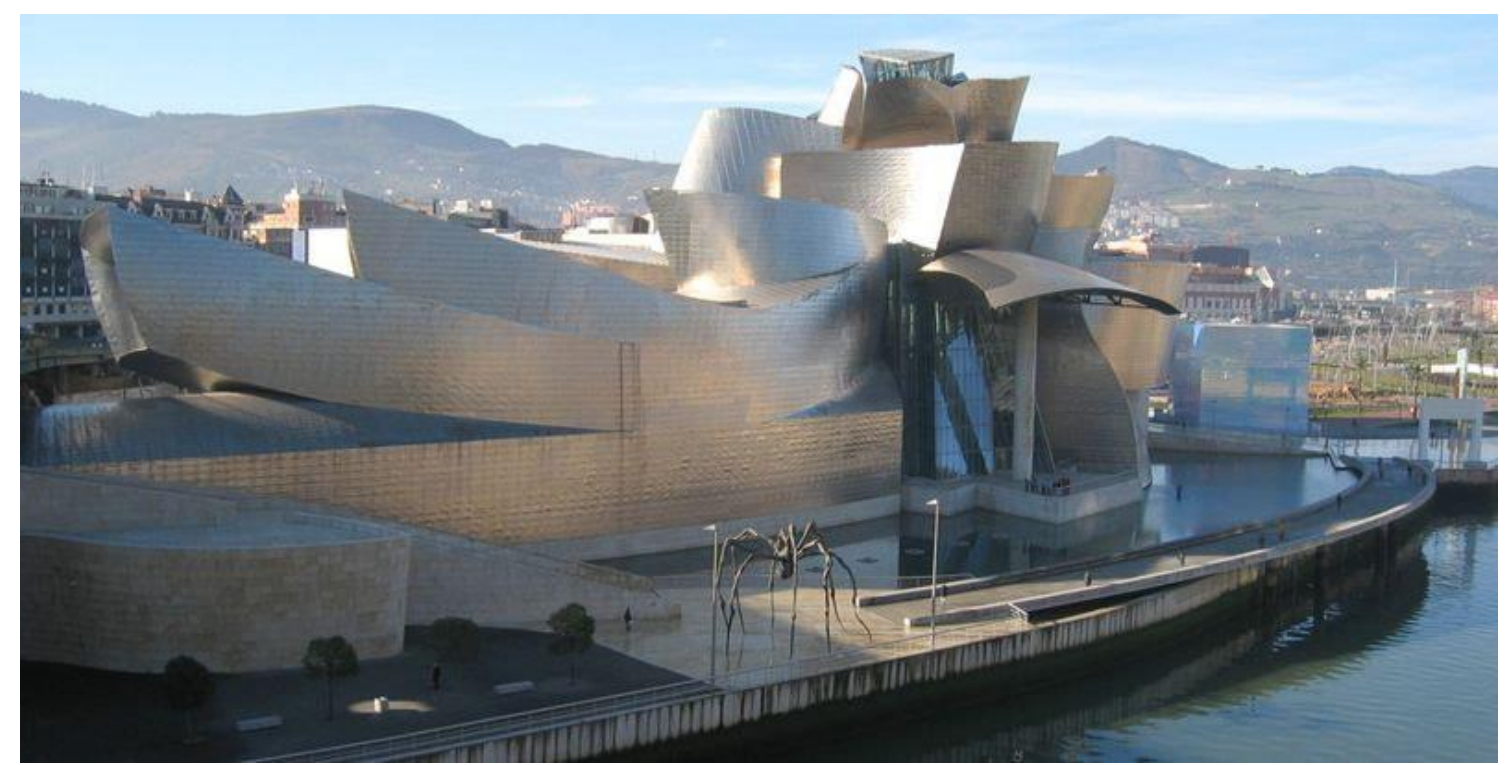

Figura 9: Museu Guggenheim, Frank Gehry (1992)

Fonte: NARDELLI, 2007

\begin{abstract}
"Para muitos arquitetos treinados pela segurança de geometrias Euclidianas o surgimento de formas curvilíneas criam grandes dificuldades. A ausência de uma teoria estética apropriada para hiper-superficies "hypersurface" parece esotérica e de difícil compreensão espacial e muitas vezes pensadas como outro modismo arquitetônico" (KOLAREVIC, 2003, p.06).
\end{abstract}

As ferramentas de geração digital eliminaram diversas restrições geométricas impostas pelos sistemas tradicionais de desenho, cuja construção sem o suporte digital seria quase impossível ou muito trabalhosa e onerosa para ser viabilizada. Estas ferramentas facilitaram a produção e construção de edifícios cada vez mais complexos e singulares. 


\begin{abstract}
"Após ter abandonado o discurso do estilo, a arquitetura dos tempos modernos é caracterizada por sua capacidade pioneira de obter vantagens desta mesma modernidade: inovações oferecidas pela ciências e tecnologia atual. A relação entre a nova tecnologia e a nova arquitetura caracteriza um marco fundamental do que hoje constitui a arquitetura de vanguarda" (KOLAREVIC, 2003, p.03).
\end{abstract}

A revolução industrial é caracteriza pela produção em massa de componentes padronizados produzidos e classificados de acordo com a forma e tamanho. Já a arquitetura de vanguarda possibilitou que os recursos digitais fossem incorporados no processo de produção através da customização em massa que permite produzir elementos construtivos específicos e únicos para o espaço edificado. A inserção dos recursos digitais modificou os paradigmas da arquitetura e possibilitou a introdução de formas complexas com elementos únicos que dificilmente poderiam ser construídas com as técnicas tradicionais.

"Uma nova sequiência digital baseada na ligação direta entre projetar e construir foi estabelecida através da tecnologia digital. As consequiência deste processo são profundas pois a tecnologia digital de projetação, fabricação e construção então desafiando a relação histórica entre arquitetura e a forma de construir" (KOLAREVIC, 2003, p. 4).

Portanto como exemplo desta tecnologia digital podemos citar os sistemas BIM, que permitiu que o arquiteto retornasse ao modelo de produção dos mestresconstrutores, perdido na alta Idade Média. Neste processo, o projetista participa das etapas da elaboração e construção das edificações. Naquela época o mestre-construtor coordenava e controlava a execução do projeto do inicio ao fim.

A tecnologia digital é um fato atual que permite confecção de objetos e construções diferenciadas de formas não Euclidianas e complexas com custos muitas vezes não superiores a construção de formas ortogonais.

\title{
3.1 GEOMETRIAS NÃO- EUCLIDIANAS
}

O pensamento arquitetônico durante séculos estava baseado no pensamento Euclidiano retratado nos esboços de Le Corbusier no livro "Vers une archtecture". O cilindro, a pirâmide, o cubo, o prisma e a esfera não eram apenas formas essenciais da arquitetura egípcia, grega e romana como observado por Le Corbusier, mas também geometrias universais primitivas dos softwares modeladores de sólidos do século XX.

Niemeyer afirma que: "Os últimos projetos de Le Corbusier denunciavam, como disse Ozenfant, um alheamento ostensivo ao ângulo reto que sempre defendera." (Niemeyer, p.40, 2005). 
Quando percebeu-se a possibilidades de construção de outras geometrias diferentes dos postulados de Euclides criou-se a nomenclatura de geometrias nãoeuclidianas. A geometria Euclidiana tem como origem os cinco postulados de Euclides que são a base para o desenvolvimento de uma geometria axiomática que serve como referência para o estudo da geometria plana. Os cinco postulados são:

1-[É possível] traçar uma linha entre dois pontos quaisquer.

2- [É possível] prolongar uma reta finita continuamente em uma reta.

3- [É possível] traçar-se uma circunferência com qualquer centro e qualquer raio.

4- Todos os ângulos retos são iguais entre si.

5- Se uma linha reta que corta duas outras linhas retas forma ângulos interiores do mesmo lado cuja soma é menor que dois ângulos retos, as duas linhas retas, se prolongadas indefinidamente, se encontrarão no lado em que a soma dos ângulos é menor do que dois ângulos retos (SILVA, 2006, p.02).

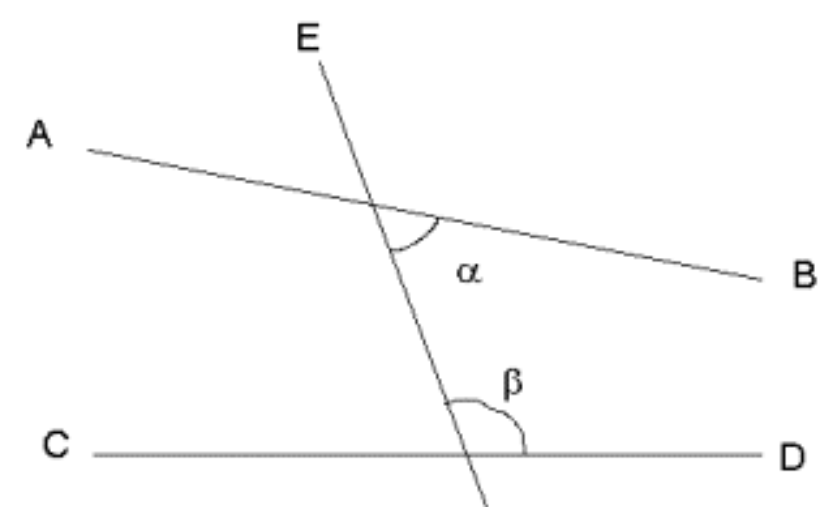

Figura 10: Quinto postulado de Euclides

Fonte: Silva, 2006

Segundo o quinto postulado de Euclides, caso as retas $\mathrm{AB}$ e $\mathrm{CD}$ se encontram do lado em que os ângulos interiores somam menos que $180^{\circ}$, então as duas retas $\mathrm{AB}$ e CD irão se encontrar quando prolongadas para esse lado. Os estudos de Euclides são formados por 13 livros que formam as bases da geometria e da aritmética. Tanto a história dos livros, como a do próprio Euclides (325 a.C. até 265 a.C.) é cheia de contradições e especulações.

Antes do século XIX não se acreditava existir uma geometria fora da delimitada por Euclides. Foi o quinto postulado que viabilizou a investigação da existência de geometrias não-Euclidianas. Giovanni Saccheri questionou pela primeira vez a existência geometrias diferentes das de Euclides (MORAIS, 2010, p.31).

Johann Carl Friederich Gauss (1777-1855) foi um brilhante matemático contemporâneo de Saccheri, considerado um dos fundadores da geometria nãoeuclidiana, pois a partir de várias de suas cartas pode-se inferir que realizava pesquisas nessa área, contudo não publicou nenhum de seus trabalhos. Mas foi Bernhard Reimann 
quem demonstrou primeiro a existência de geometria não-Euclidiana ao constatar a não aplicação do quinto postulado. Riemann não escreveu uma grande quantidade de trabalhos, mas os que produziu influenciaram tanto a matemática, física $\mathrm{e}$ principalmente a teoria da relatividade de Einstein. (SILVA, 2007, p. 39)

"O trabalho de Gauss, Labochevsky, Raimann, Von Helmholtz e outros matemáticos e físicos, mais tarde, mostraram que o espaço não é apenas curvo, mas também é multidimensional.”( KOLAREVIC, 2003, p.14.) Através de demonstração que a geometria pode ser baseada em relações não-Euclidianas, abriu-se novas possibilidades e potencialidades também para arquitetura. KOLAREVIC afirma que a concepção arquitetônica se move a partir da terceira dimensão do espaço cartesiano para a quarta dimensão que é o tempo. A quarta dimensão, o tempo, proporciona experiências diferentes de acordo com o "passeio" ou ponto de vista do observador.

\footnotetext{
“ $\mathrm{O}$ que muitas vezes encontra-se omitido é que está nova arquitetura "smooth" suave, arredondada, sem ângulos, encontra-se intrinsecamente agregada aos princípios amplos do design. Os contornos arredondados estão excessivamente presentes na nossa vida em boa parte de décadas passadas deste a escova de dentes, torradeiras e computadores até carros e aviões, porém provavelmente por falta de uma metodologia convincente as curvas foram ignoradas pela arquitetura há alguns anos atrás. Esta ignorância formal de tendências dominantes tem origina em outra ignorância ou negligencia a tecnologia relacionada com os softwares de modelagem em três dimensões que facilitam a construção de curvas suaves que estão disponíveis no desenho industrial. Historicamente a indústria da construção foi a última a se adaptar as novas tecnologias; CATIA (Computer Aided Tree-dimensional Interactive Aplication) foi usada há 20 anos antes de ser descoberta pelo escritório de Gehry e atualmente é utilizada por poucos escritórios." (KOLAREVIC, 2003, p. 6.)
}

A introdução de softwares de modelagem digital no projeto de arquitetura permitiu uma nova abordagem de formas arquitetônicas. A geometria Euclidiana dos volumes discretos representados no plano cartesiano abre espaço ao uso de curvas contínuas e superfícies que são características da arquitetura contemporânea. As superfícies altamente curvilíneas na arquitetura digital são descritas matematicamente como NURBS, Non-Uniform Rational B-Spline, ou curva racional não- uniforme (KOLAREVIC, 2003, p.15).

Os NURBS são funções paramétricas que podem representar qualquer tipo de curva. São usadas para representar objetos com curvas complexas na computação gráfica, indústria de CAD/CAM, automobilística, aviação e naval.

Os softwares de modelagem mais sofisticados fornecem interface para elaborar as curvas NURBS, que são flexíveis o suficiente para projetar grande variedade de 
formas. Os NURBS trabalham bem em modelagem tridimensional, pois possuem recursos para manipulação e controle dos vértices. O número de pontos de controle de uma superfície define o seu grau de precisão da forma. Quanto maior for o número de pontos, maior será a precisão e controle do modelo.

"NURBS provêm de uma base matemática, unificada para representar ambas as formas analíticas como seções cônicas e superfícies quadráticas, além de entidades de formas livres, como formas de carros, navios e aviões" (MINETTO, 2003, p.12.).

Um dos motivos de usar NURBS é devido a sua capacidade de proporcionar grande domínio sobre a forma, permitindo definir curvas sem torcer ou mudar subitamente de direção ou com controle preciso acima de onde se torce e a curva acontece. O domínio das curvas NURBS é através de um conjunto de pontos de controles e nós e podem ser manipulados para controlar a suavidade e curvatura. Esta curva pode representar formas complexas, através de poucos dados. Como exemplo, poderíamos afirmar que um círculo é composto por dezenas de milhares de segmentos para fazer parecer que é um círculo, ao invés de um polígono. O mesmo círculo com uma representação NURBS comporta somente sete pontos de controle. " O projeto com NURBS é intuitivo, quase toda ferramenta e algoritmo tem um fácil entendimento de interpretação geométrica” (MINETTO,2003, p.12.).

\subsection{BOAS PRÁTICAS DE USO E APLICAÇÃO DA LUZ NATURAL 3.21 PREFEITURA DE LONDRES “CITY HALL"}

A Sede da Prefeitura de Londres na Inglaterra está localizada no South Bank em terreno às margens do rio Thames. O projeto com área de $19.814 \mathrm{~m}^{2} \mathrm{e}$ altura de 45 metros foi elaborado pelo escritório de arquitetura Fosters and Partners, sendo concluído em 2002. Faz parte do programa de estímulo ao crescimento econômico de áreas próximas ao rio.
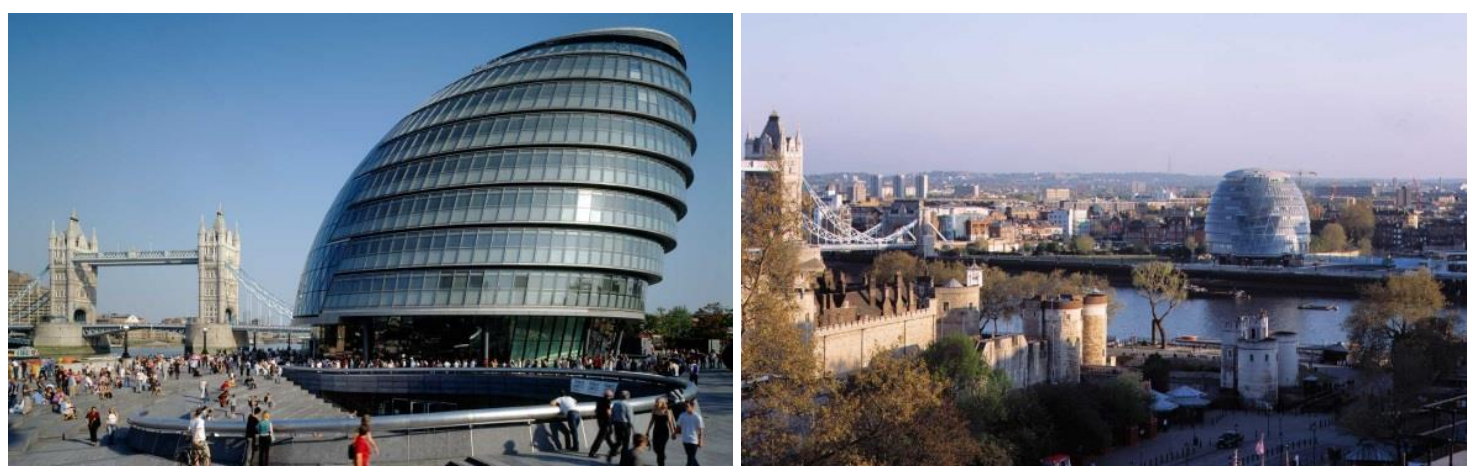

Figura 11: Prefeitura de Londres

Fonte: http://www.fosterandpartners.com/projects/city-hall/ 
O acesso público ao edifício é feito através de um amplo anfiteatro abaixo do nível da rua que conduz a um café e espaço destinado a exposições. Possui uma rampa em espiral que conduz a todos os pavimentos, inclusive a cobertura e permite a visualização de diferentes ângulos da cidade de Londres, através da fachada formada por panos de vidro triangulares. A cada passo na rampa é possível vislumbrar novas vistas da cidade além de algum movimento de dentro dos escritórios.

O City Hall foi projetado para poupar energia e aproveitar a luz natural. O processo de projetação foi todo assistido por computador, inclusive a análise de conforto ambiental como exemplo pode ser citado o estudo de incidência solar no edifício, e a análise acústica para a assembleia.

A simulação computacional permitiu estudos de ordem acústica e reprovou a solução inicial do projeto em virtude da emissão de ondas sonoras no recinto. A proposta inicial para a sala de reunião era baseada em uma forma muito suave. Especialistas em acústica explicaram que a sala de reunião seria excessivamente reverberante e era necessário a tomada de algumas medidas para garantir a absorção o que provocou alterações no projeto. Assim o projeto foi alterado em função da grande quantidade de reverberação. O escritório Arup desenvolveu um processo para visualizar o som sendo refletido e absorvido em superfícies diferentes, e, depois de várias iterações, uma solução surgiu que era aceitável arquitetonicamente e acusticamente. A solução adotada foi a introdução de rampa em formato helicoidal e material com alto coeficiente de absorção sonora.

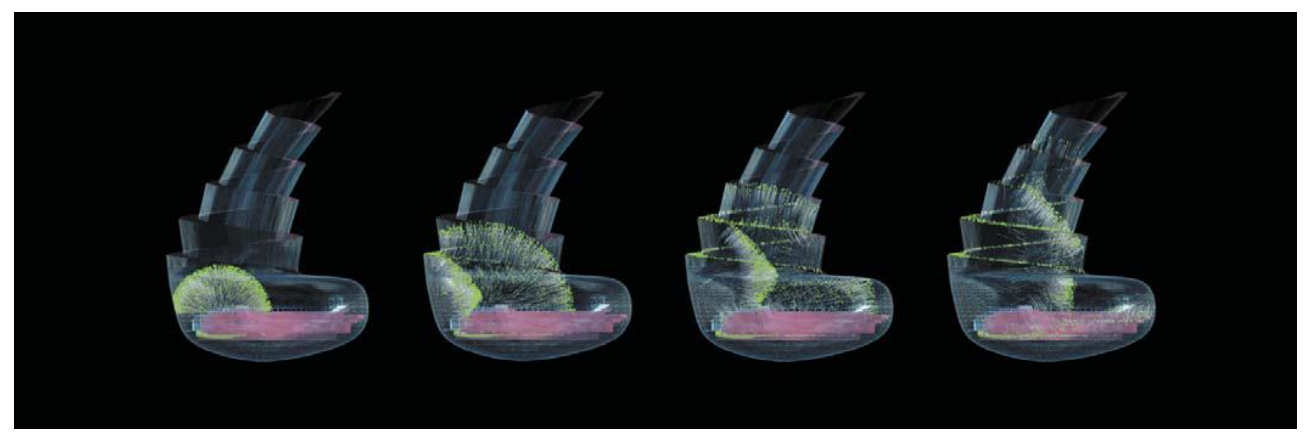

Figura 12: Simulação acústica do City Hall Fonte: Kolarevic e Malkawi, 2005, p.49 


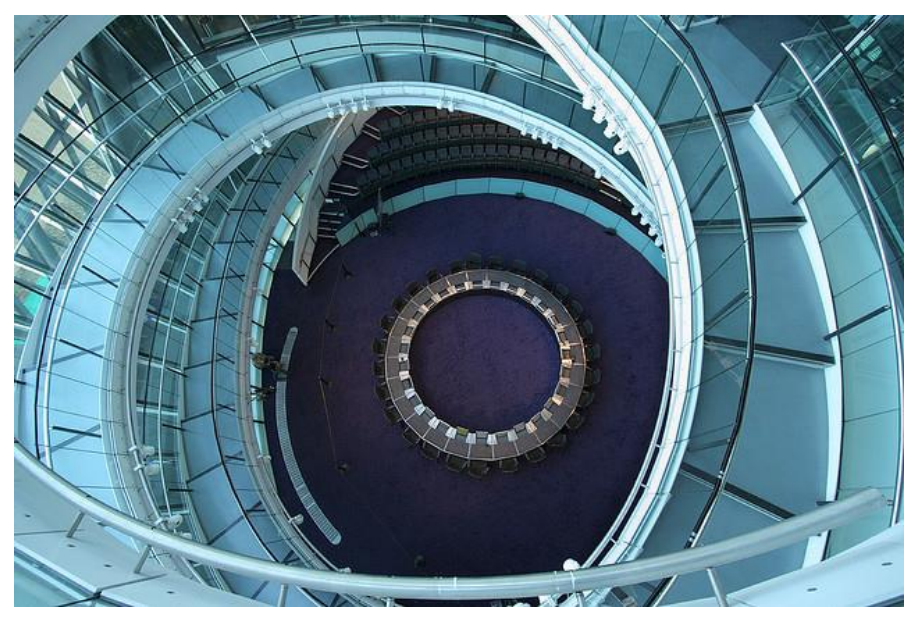

Figura 13: Rampa sala de reunião

Fonte: http://arktetonix.com.br/2011/12/ark-inspiration-157-\%E2\%80\%93-city-hall/

Para o estudo da volumetria do projeto foi utilizada a modelagem paramétrica através do software Macrostation da Bentley e foram elaboradas maquetes através de prototipagem rápida para estudo comparativo de melhor solução para o projeto. Os modelos 3D (figura 14) mostram as modificações na geometria esférica até atingir um formato elipsoide inclinado correspondente ao projeto (ABEL, 2004, p. 154).

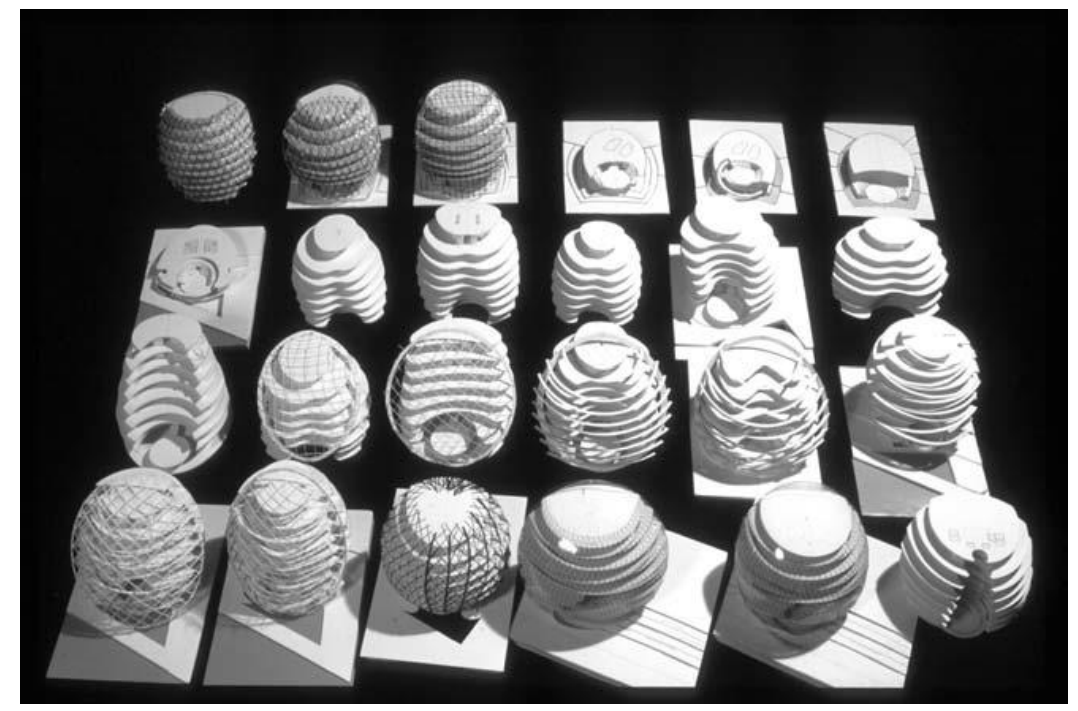

Figura 14: Maquetes com estudos e alterações no projeto Fonte: ABEL, 2004, p. 155.

A implantação e a forma do edifício foram desenvolvidas visando à economia de energia. Ao usar a esfera, buscou-se minimizar a área de superfície do edifício exposta diretamente à luz solar. A análise dos estudos energéticos teve um impacto importante sobre o desenvolvimento do projeto. Desde o inicio pretendeu-se projetar um edifício 
que fosse eficiente do ponto de vista energético e que a sua forma tivesse propriedades especiais para tanto (KOLAREVIC, 2003, p.86).

Norman Foster adepto ao uso das cortinas de vidro idealizado por Mies van de Rohe fez uma releitura desta tipologia através do uso de fachadas curvas de vidro acompanhando a dinâmica dos raios solares.

Os engenheiros da Arup foram contratados para fazer o estudo solares do projeto proposto, e produziu imagens codificadas com superfícies coloridas de acordo com a quantidade total de energia que cada painel de revestimento receberia durante um ano. Forneceram também valores de irradiância em planilhas para que distribuição pudesse ser analisada detalhadamente.

Através de estudos foi constatado que a fachada sul estava atuando conforme esperado, ela estava auto sombreada como mostra a figura 15 nas áreas coloridas de azul. As fachadas leste e oeste na cor verde indica que os ângulos oblíquos de incidência limitam os ganhos solares. Mas na fachada norte onde o átrio glazing estaria localizado, havia apenas uma fina faixa azul. A área protegida não era o suficiente para o que havia sido planejado existia um conflito entre o projeto e os resultados da análise solar. $\mathrm{O}$ estudo solar mostrou que o sistema glazing deveria ser alterado então neste caso o diagrama de cores levou a solução da fachada. O mesmo estudo também mostrou um ponto de incidência solar localizada no topo do edifício, ideal para o posicionamento dos painéis solares (KOLAREVIC, 2003, p.87).
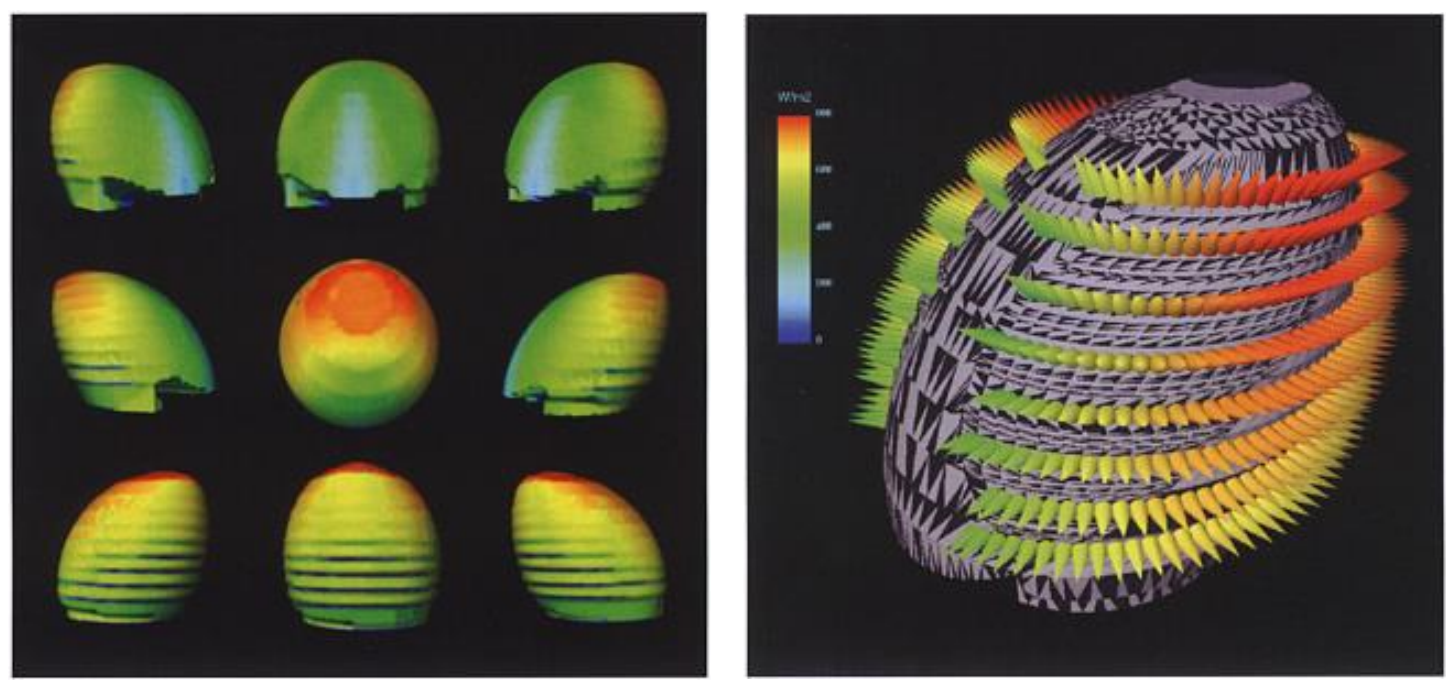

Figura 15: Estudo Solar do Edifício Fonte: KOLAREVIC, 2003, p.86 e 87

A fachada envidraçada da Prefeitura está voltada para o Norte, onde há menor insolação direta, o que evita aquecimento excessivo enquanto permite utilização da luz 
natural. Essa solução permitiu a utilização de uma cortina de vidro nesse local (Figura 16), sem ocasionar aumento dos níveis térmicos no interior imediato à cortina. Esta cortina de vidro é dividida em painéis triangulares e planos, que se encaixam permitindo a reprodução da curvatura elipsoide. Na fachada Sul que é mais suscetível ao sol no hemisfério Norte, foi criada uma volumetria em forma de escada invertida que permite áreas sombreadas na fachada. A inclinação do edifício para o sul serve também para a otimização do sistema fotovoltaico de captação de energia solar.

\section{Building form is developed to respond to the sun-path}

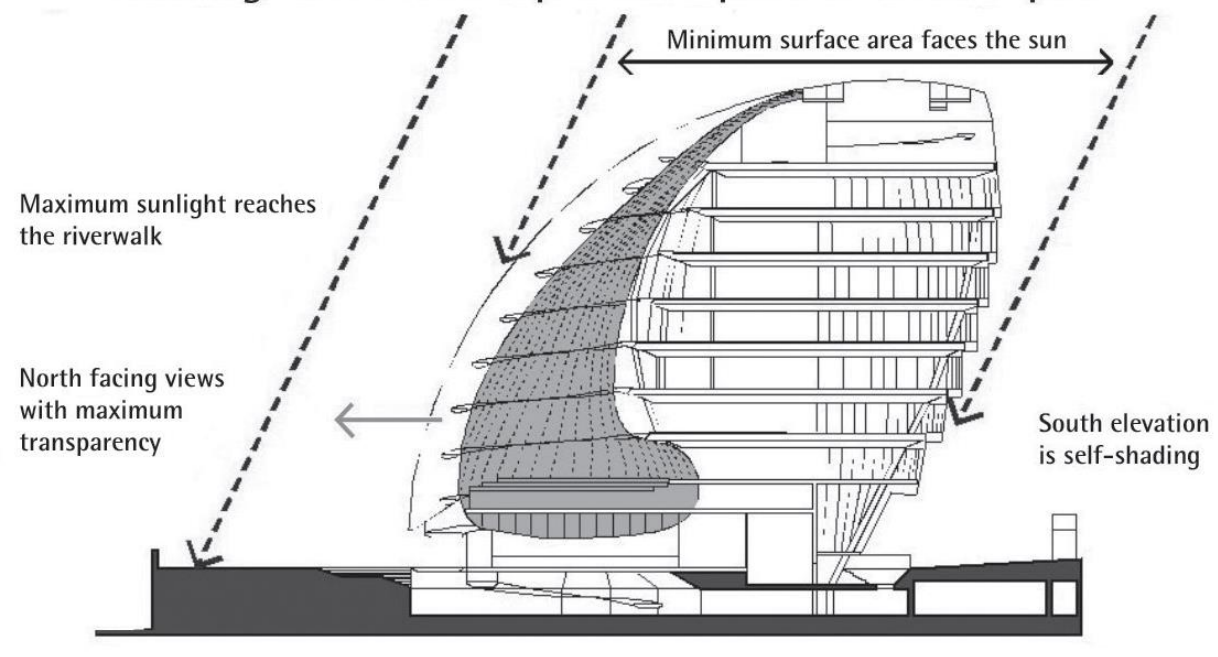

Figura 16: Diagrama da iluminação solar Fonte: KOLAREVIC, 2003, p.85

Visto que cada painel teria um dimensionamento único foi utilizado para construção a fabricação digital onde os painéis do átrio e fachada foram cortados através de maquinas CNC que garantem alto grau de precisão. Cada componente de revestimento foi fabricado com código de barras, para permitir um acompanhamento preciso durante a produção e o processo de montagem.

Um sistema integrado de controle ambiental consegue minimizar o uso de energia. Através de Dinâmicas Computacionais de Fluidos (Computacional Fluid Dynamics - CFD) o efeito do edifício sobre as direção dos ventos foi simulado. Os escritórios recebem ventilação natural por dutos de ar posicionados sob as janelas. $\mathrm{O}$ sistema mecânico de refrigeração utiliza água fria bombeada do térreo até dutos instalados no forro, evitando a necessidade de sistemas complexos de refrigeração. A previsão é que o consumo de energia deve ser reduzido em um quarto, se comparado ao de um edifício similar climatizado com um sistema convencional. 


\subsection{ST. MARY AXE}

Nesta mesma linha de pensamentos que a forma foi planejada considerando aspectos bioclimáticos podemos citar o edifício 30 St. Mary Axe (1997-2004), localizado no centro financeiro de Londres. O edifício de escritórios também projetado por Norman Foster possui 41 pavimentos com área de 46.400 metros quadrados. O prédio pertencia à empresa de seguros Swiss Re e por isso anteriormente o edifício levava o nome da corporação. Atualmente, seu nome oficial é originário de seu endereço. O projeto teve como premissa a otimização do uso da luz e ventilação natural, reduzindo os gastos energéticos do edifício (Disponível em: http://www.fosterandpartners.com/projects/30st-mary-axe/. Acessado em 01/02/2016).
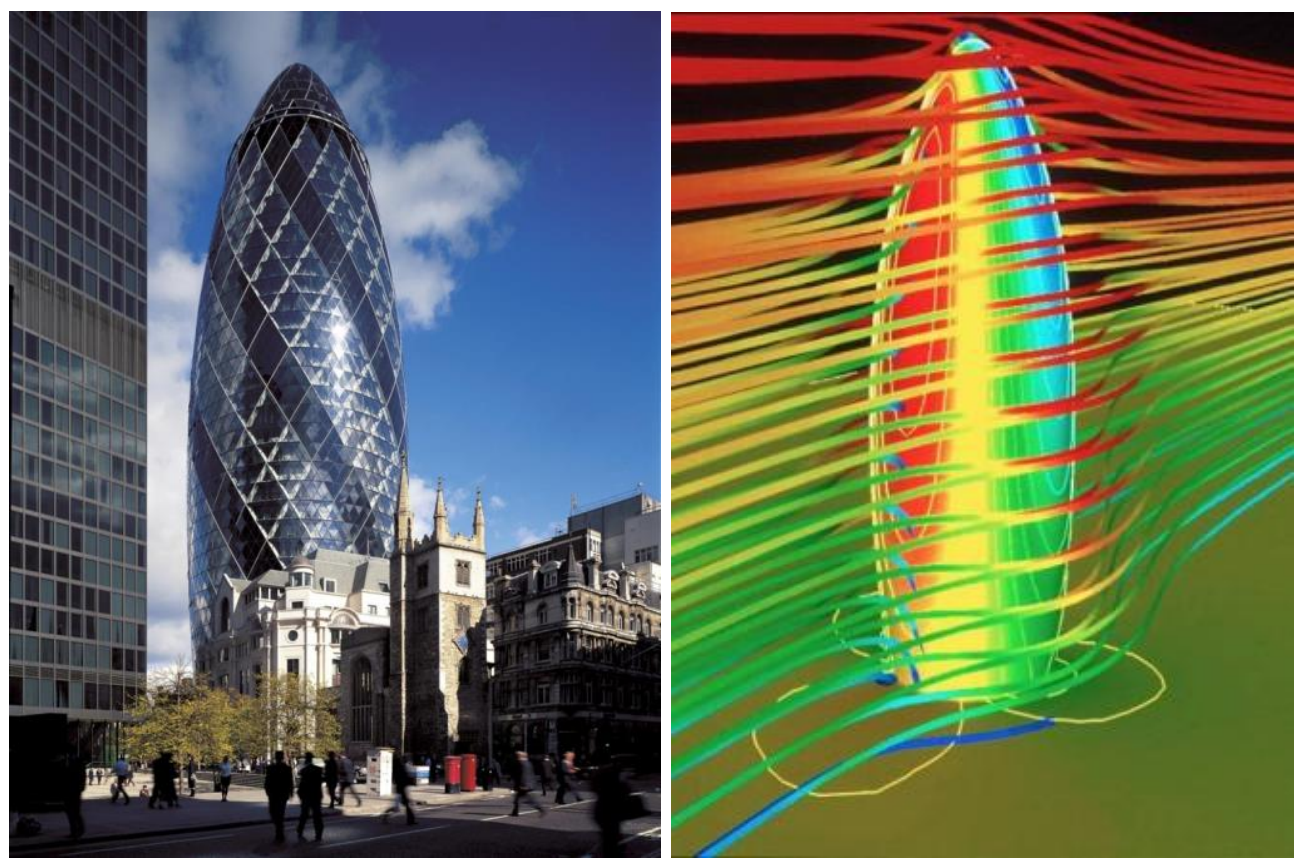

Figura 17: Edifício Swiss Re e Simulação dos ventos

Fonte: http://www.fosterandpartners.com/projects/30-st-mary-axe/ e GARCIA, 2014, p.73

As decisões estruturais e arquitetônicas foram baseadas no uso de técnicas de projeto auxiliadas por computador com modelagem paramétrica usada pelo programa Generative Components da Bentley. No processo de projeto foram analisadas questões ambientais através de ferramentas de simulação computacional. Entre elas podemos citar a análise através da Dinâmica Computacional de Fluidos (CFD) que permite mensurar a velocidade dos ventos, a pressão atmosférica, os efeitos ambientais do edifício no entorno e temperatura em certos pontos do projeto. Os estudos ambientais e urbanísticos foram determinantes na concepção da morfologia do edifício.

A forma ogival com 180 metros de altura, foi definida não só por suas características aerodinâmicas para minimizar os esforços causados pela ação dos ventos, 
mas também por maximizar a entrada de luz natural e da ventilação. Esta forma permite dimensões maiores no diâmetro da planta baixa em andares superiores e redução do diâmetro ao nível do solo respondendo à demanda do pequeno terreno no qual a obra foi construída.

A fachada é composta por painéis de vidro duplo ancorados em treliças de aço estrutural que permite a ventilação e a captação de luz natural. Os vidros duplos da fachada externa possuem tons de cores diferentes combinado a uma película de proteção solar que reduz a incidência de luz natural direta.

O prédio possui sistema de gerenciamento predial onde as janelas são controladas por computadores. Existem pontos de entrada de ar na envoltória externa da fachada e espaço para troca de ar dentro das câmaras e persianas motorizadas na pele interna. Quando o sistema está desativado as persianas podem ser controladas pelos usuários a partir da área de trabalho.

"Conceitualmente, a camada de ar conformada pela cavidade de uma fachada dupla ventilada vai se aquecendo com a incidência de radiação solar através da segunda pele de vidro e, por diferença de pressão, tende a subir, conformando um fluxo de ar. Dependendo de cada contexto especifico, tal fluxo pode reduzir a temperatura superficial da primeira pele, reduzindo, como consequência, a transferência de calor para o ambiente interno" (MARCONDES, 2010, p.74).
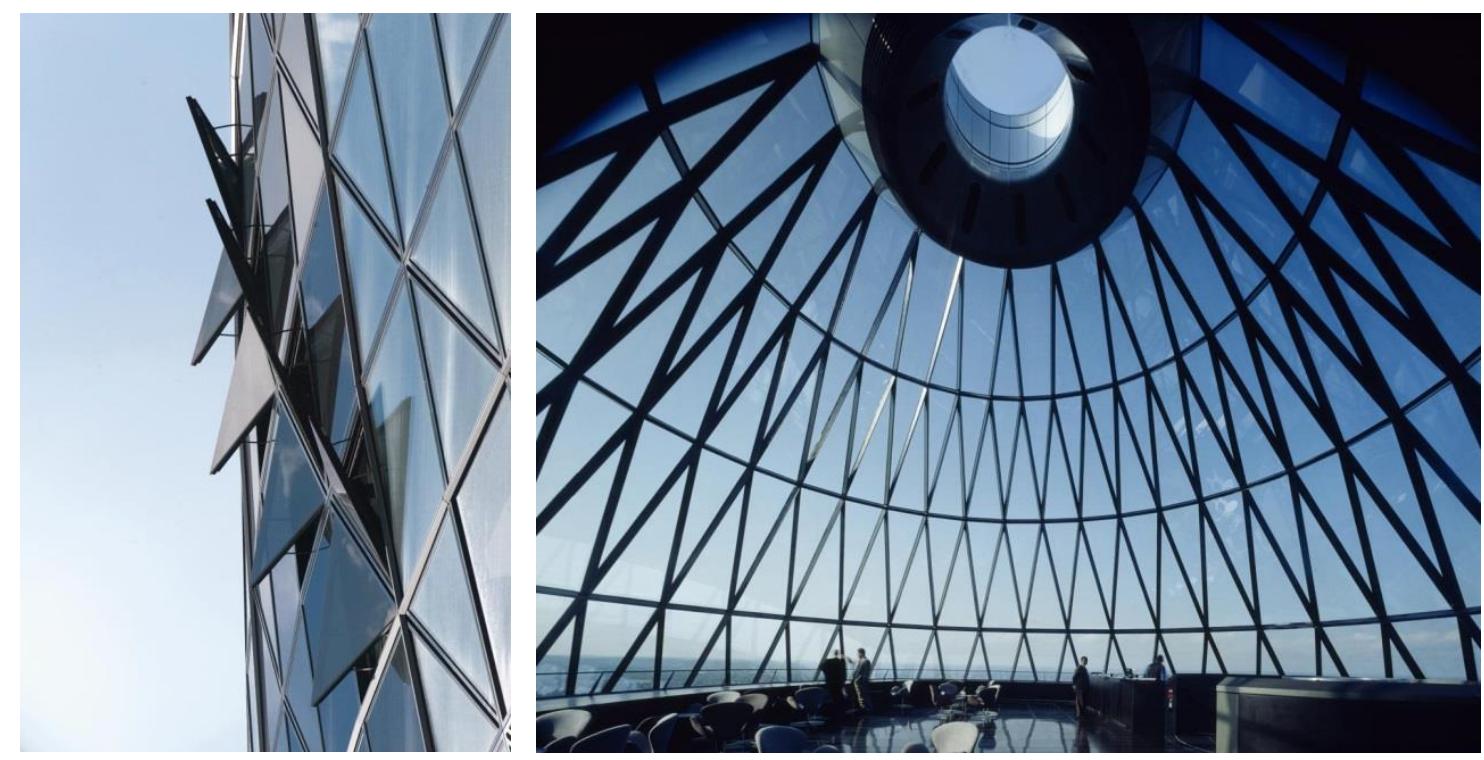

Figura 18: Aberturas na fachada e cúpula

Fonte: http://www.fosterandpartners.com/projects/30-st-mary-axe/

O projeto estrutural foi desenvolvido pelo escritório Arup, com um sistema de ventilação natural que, através de poços de luz distribuídos da base ao topo do edifício, permitem a troca de ar nos ambientes internos. A estrutura metálica periférica, em 
espiral, resiste às cargas horizontais, enquanto a estrutura do núcleo sustenta as cargas verticais. O projeto teve redução do consumo energético em $50 \%$ em comparação com construções tradicionais.

\subsection{INSTITUTO DO MUNDO ÁRABE}

O Instituto do Mundo Árabe (IMA) em Paris projetado por Jean Nouvel, faz uma releitura de elementos da cultura árabe como os muxarabis. Os muxarabis estão localizados na fachada sul do edifício sendo utilizado para filtrar a luz natural excessiva. Estes em forma de mosaico criam elementos que abre e fecha de acordo com a intensidade luminosa do exterior, tudo isso controlado mecanicamente com o auxílio de sensores fotossensíveis. O efeito no interior do prédio é o controle da entrada de luz natural.

A fachada norte, voltada para o Rio Sena, é revestida em vidro espelhado. O edifício construído na década de 80 utiliza-se de uma tecnologia inovadora para filtrar a luz natural criando também uma fachada dinâmica, que muda de acordo com o fechamento ou abertura dos diafragmas (http://www.archdaily.com/162101/ad-classics-institut-dumonde-arabe-jean-nouvel).
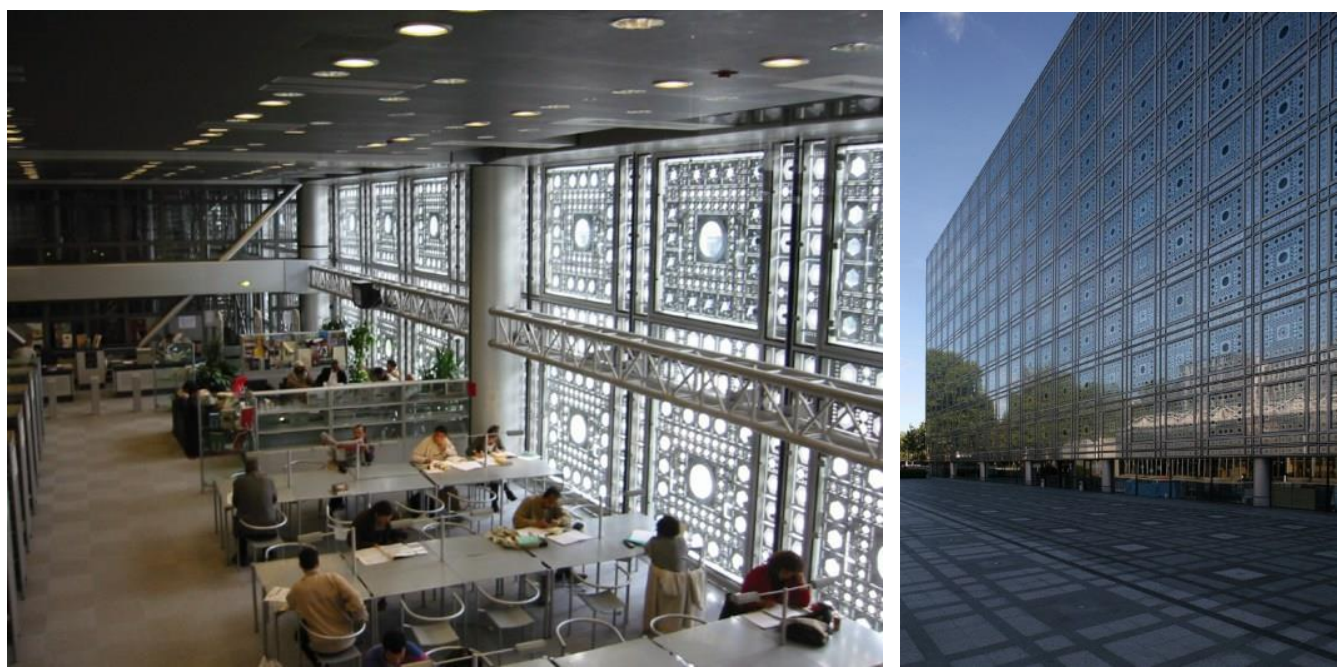

Figura 19: Instituto Mundo Árabe

Fonte: https://architetour.wordpress.com/2009/10/13/instituto-do-mundo-arabe/

\subsection{QUADRACCI PAVILLION}

O Quadracci Pavilion localizado na cidade de Milkwaukee nos Estados Unidos as margens do lago Michigan, é uma expansão do Museu de Arte de Milwaukee. Projetado pelo arquiteto Santiago Calatrava (1994- 2001) que propôs uma forma 
singular inspirada na natureza que mistura formas orgânicas e tecnologia de ponta da época. O projeto tornou-se logomarca do museu e um dos principais ícones da cidade.

O elemento visual mais marcante do projeto possui o formato de um paraboloide hiperbólico similar a asas de um pássaro que funciona como um brise-soleil. $\mathrm{O}$ brisesoleil é composto por braços móveis em tubos retangulares de aço com uma envergadura de aproximadamente 66 metros que se moverem para controlar a incidência de luz natural e temperatura sobre a entrada principal do museu. Internamente o Museu abriga um átrio em formato oval onde está localizada a área de exposição (POLONINI, 2014, p.149).

$\mathrm{O}$ projeto integra o museu à cidade através de uma praça de lazer e eventos culturais onde estão localizadas duas fontes com cerca de doze metros de diâmetro. Outro elemento importante do projeto é a passarela de pedestres que conecta a entrada principal do museu à faixa que margeia o lago ao centro da cidade.

O sistema construtivo do edifício é em concreto armado e o brise-soleil e o átrio são de aço (THE PHAIDON..., 2004, p. 721 apud POLONINI, 2014, p.150 ).

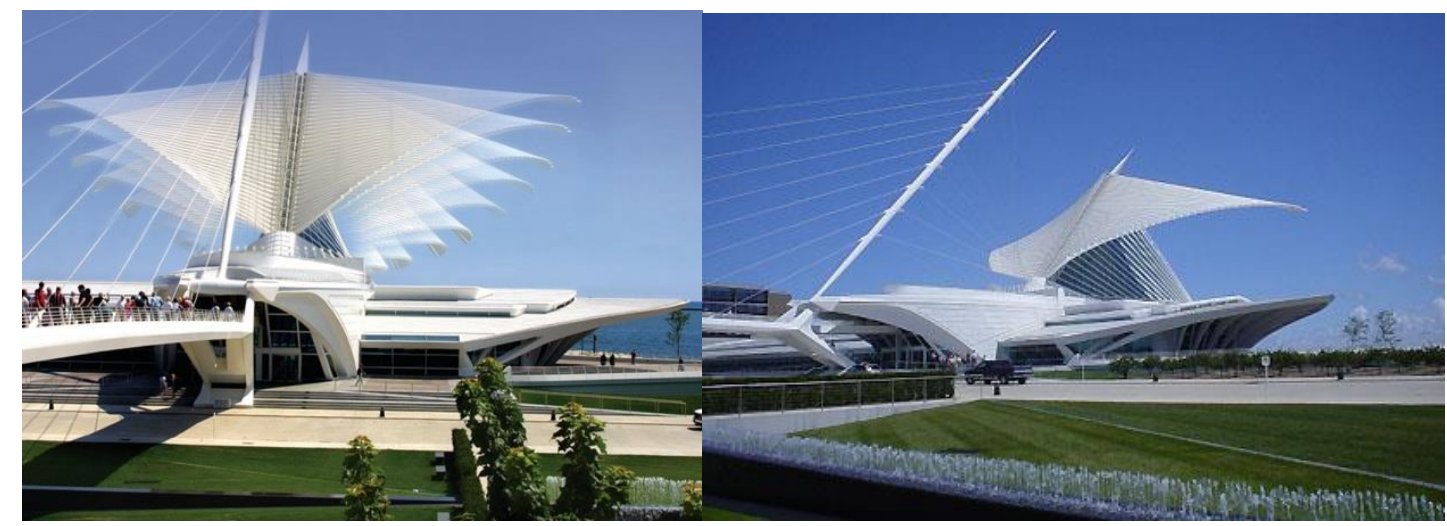

Figura 20: Quadracci Pavillion

Fonte: http://arcoweb.com.br/projetodesign/arquitetura/santiago-calatrava-museu-de-19-05-2002

\subsection{JOÃO FILGUEIRAS LIMA (LELÉ) / REDE SARAH}

No Brasil podemos citar como grande destaque de arquitetura, baseada no desempenho climático, os edifícios projetados pelo arquiteto João Filgueiras Lima (Lelé). Os melhores exemplos de soluções arquitetônicas que incorporam a luz natural e os ventos aos ambientes internos estão na Rede SARAH de Hospitais de Reabilitação.

Lelé desde suas primeiras obras incluía sistemas construtivos pré-fabricados como os Sheds orientados de forma a otimizar o uso da luz natural e ventilação visando o conforto ambiental e eficiência energética. Nas clínicas, quartos, consultórios e 
corredores, a luz natural é utilizada de forma ampla através da combinação de grandes janelas de vidro, aberturas e sheds.

"Os Sheds são elementos arquitetônicos que têm uma presença marcante em todos os hospitais da Rede Sarah; além do valor estético, eles dão unidade ao conjunto e caracterizam a linguagem arquitetônica de toda a Rede. Sua principal função e razão de ser é permitir a entrada de luz natural e favorecer a ventilação vertical, através do efeito sucção. Sua forma é consequência, principalmente, da eficiência do efeito sucção, fazendo parte também das suas diretrizes evitar a insolação direta e favorecer a iluminação natural" (MONTEIRO, 2006, p.162).

Vale acrescentar que Lelé projetou sheds com volumetrias diferentes para cada hospital da Rede Sarah. Os fatores que influenciaram esta diversificação foi o clima de cada cidade e sua localização. Os sheds do Hospital Sarah Brasília- Lago Norte são formados por treliças com função de testeiras e brises para controle da luz natural. Como o Hospital encontra-se próximo ao Lago Paranoá são aproveitadas as brisas do lago para ventilação.

No Centro de Reabilitação Sarah do Rio de Janeiro observa-se um desenho mais evoluído. A treliça é uma peça única com seção variável que serve para economizar material. Sob a superfície convexa aparece outra superfície com formato invertido que serve como duto do sistema de ar condicionado. O eixo central do shed possui um pé direito maior, cujo o vão superior serve para entrada de luz natural. Na altura menor do shed estão localizados os difusores por onde o ar frio é insuflado.

"Considera-se que, o design das aberturas ou janelas atende a variáveis além de uma simples preocupação com a estética e a linguagem arquitetônica. Seu design deverá conter arranjos e dispositivos que atendam às condicionantes climáticas e favorecem o conforto dos ambientes internos. A dimensão e a posição de uma abertura determinará uma eficiente ventilação e iluminação natural" (MONTEIRO, 2006, p.117).

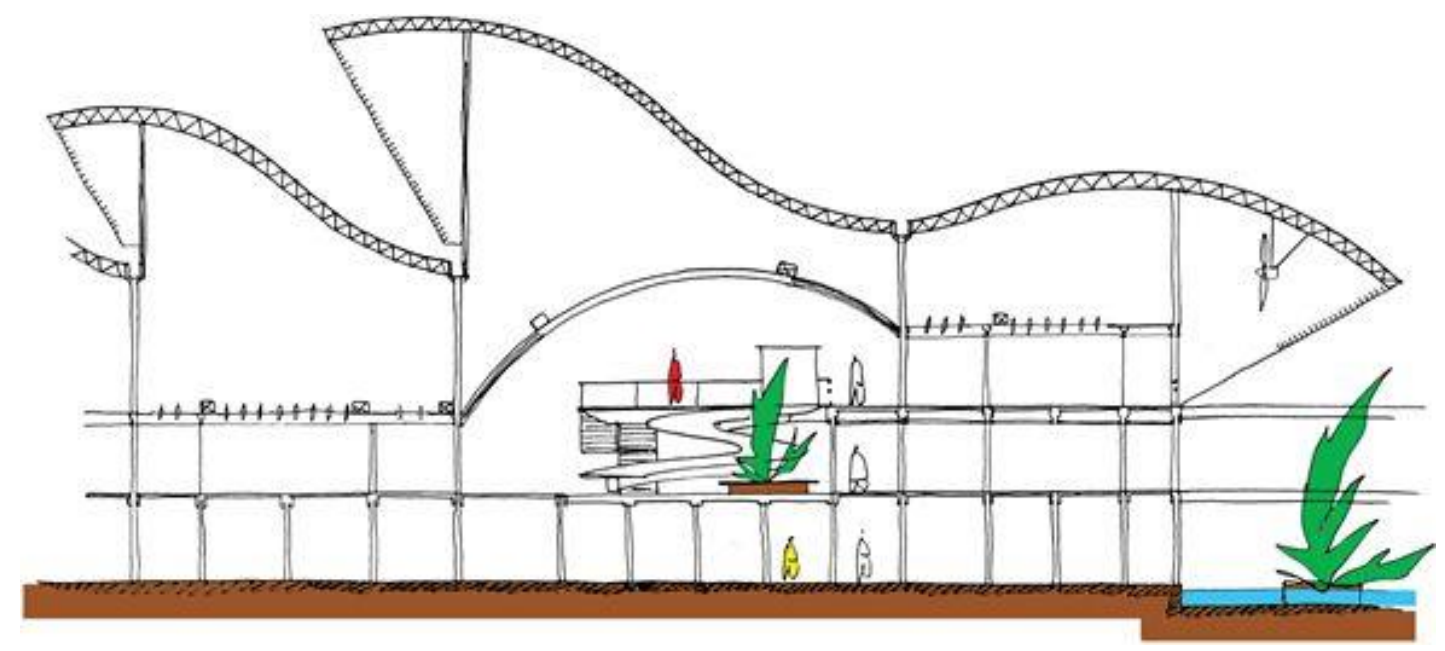

Figura 21: Sheds do Sarah do Rio de Janeiro

Fonte: http://au.pini.com.br/arquitetura-urbanismo/243/artigo313008-4.aspx 


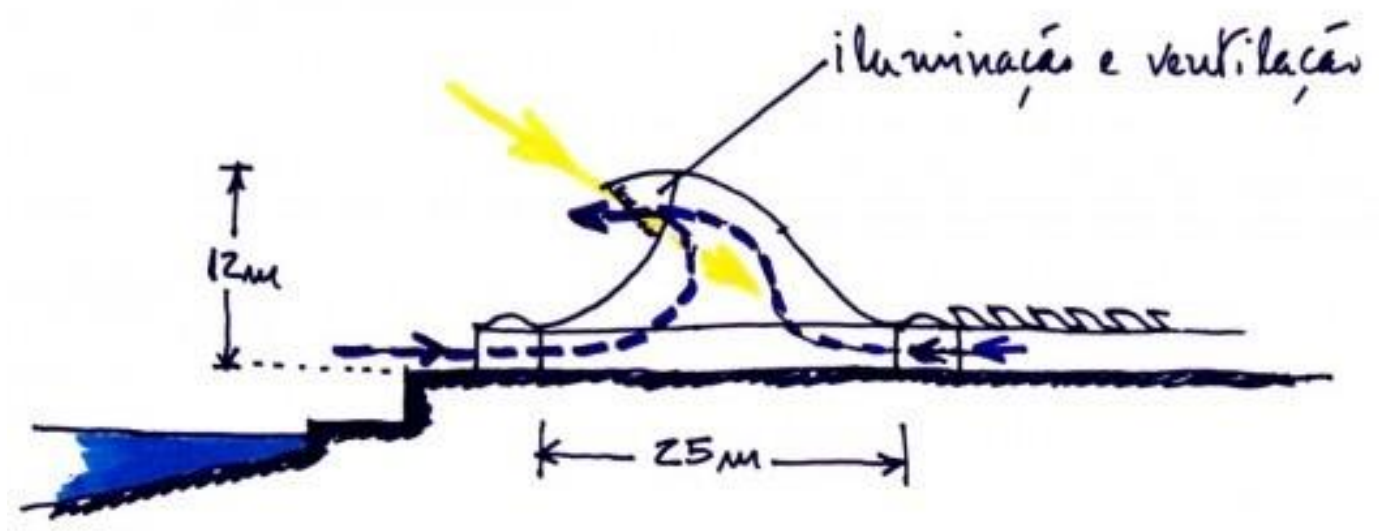

Figura 22: Sheds do Sarah Brasília

Fonte: http://www.vitruvius.com.br/revistas/read/projetos/13.153/4865

Segundo Lelé é a luz natural o aspecto primordial na arquitetura. No desenvolvimento de seus projetos sempre houve a preocupação com o uso da luz natural que segundo ele é mais agradável e quando difusa não deixa sombras sobre a mesa de trabalho, como a luz artificial. Afirma ainda que houve um longo período após a Segunda Guerra Mundial onde se preconizava uma arquitetura feita com base nas tecnologias disponíveis com a luz artificial e ar-condicionado (MENEZES, 2004, p.67).

A característica marcante de seus trabalhos é o uso de sistemas naturais de iluminação e ventilação. Em quase todos os ambientes da Rede Sarah usa-se como principal fonte de iluminação a luz natural e não existe a necessidade de ligar a luz artificial durante o dia. A exceção está nas salas de cirurgias visto que têm muitas cirurgias longas e muitas vezes durante a noite é necessário o uso da luz artificial (MENEZES, 2004, p.68).

Outra questão importante que deve ser considerada é a infecção hospitalar ocasionada por bactérias que adquiriram resistência aos antibióticos. Quanto mais hermético o projeto de hospital mais propicio ao fortalecimento de bactérias. Neste contexto o ar-condicionado favorece manter o ambiente fechado. Na maioria dos projetos os dutos de ar-condicionado por onde passa a ventilação são inacessíveis dificultando sua limpeza. Assim defender o uso de luz e ventilação natural não é apenas uma questão de economia de energia é também tornar o ambiente mais saudável e humano para proteger contra infecções hospitalares.

Em ambientes como o Rio de Janeiro e Bahia, com temperaturas muito elevadas, muitas vezes não é possível resolver o conforto térmico apenas por ventilação natural. Em áreas onde é preciso ter ar-condicionado foi projetado um sistema que permite sua 
limpeza. No sistema proposto para o Rio de Janeiro existem três alternativas em momento de pouco calor a ventilação é forçada usando ventiladores; em momentos mais frescos a ventilação é natural através de aberturas dos sheds no teto e janelas; e em períodos com temperatura muito elevada é utilizado um sistema água gelada circulante que estão produz o ar condicionado. Com isto no mesmo dia pode ser utilizado os três sistemas que são automáticos (MENEZES, 2004, p.70).

Os sistemas de pré-fabricação são utilizados em todas as etapas dos projetos da Rede Sarah, desde a estrutura, até objetos hospitalares, como a cama-maca. Graças ao desenvolvimento tecnológico e profundo conhecimento das técnicas de ventilação e iluminação natural, Lelé criou um repertorio formal próprio com espaços agradáveis, econômicos e funcionais. O arquiteto consegue em suas obras integrar a forma com a infraestrutura através de soluções formais harmoniosas. As soluções adotadas são decorrentes das exigências do programa arquitetônico, clima, sistema construtivo e dos aspectos do conforto ambiental. Lucio Costa remete ao Lelé como o arquiteto onde arte e tecnologia se encontram e se entrosam.

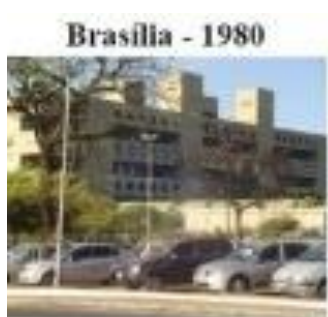

Rio de Janeiro - 2002

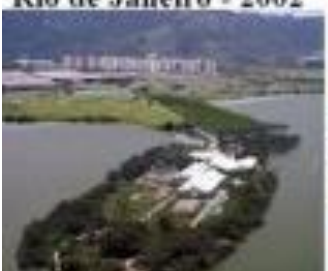

Sằo Luis - 1993

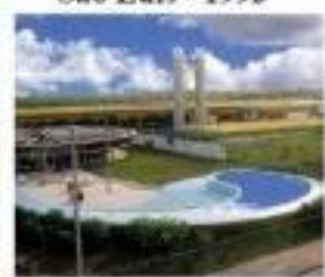

Brasilia - 2003

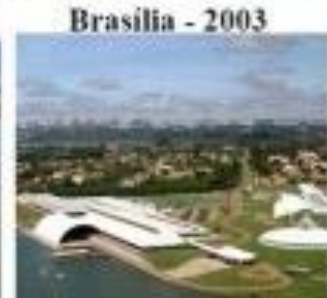

Salvador - 1994

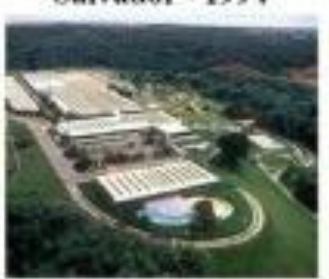

Macaná $=2005$

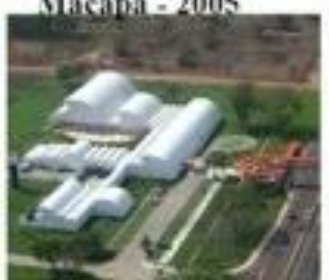

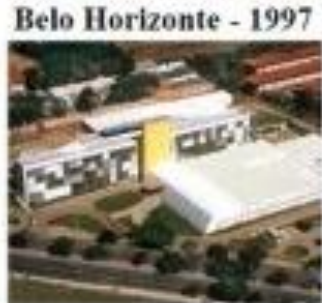

Belém - 2007

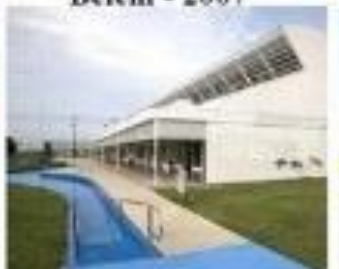

Fortaleza - 2001

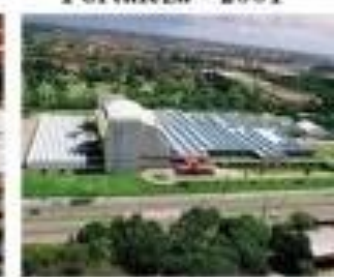

Rlo de Janeiro - 2009

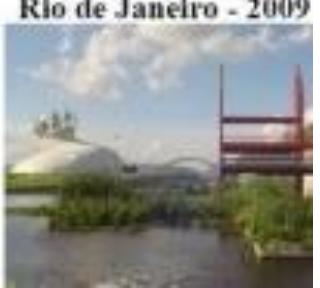

Imagem 23: Rede Sarah de Hospitais

Fonte: http://www.vitruvius.com.br/revistas/read/arquitextos/12.134/3975 


\subsection{A EVOLUÇÃO DA REPRESENTAÇÃO DE PROJETOS DE ARQUITETURA}

O tema abordado nesta dissertação resulta da evolução de técnicas que auxiliam os arquitetos e urbanistas a representar e estudar o projeto a ser construído. Portanto é importante entender como aconteceu a evolução das primeiras técnicas de estudo e representação do projeto de arquitetura e urbanismo até os dias atuais para que sejam elucidadas as questões relacionadas à simulação computacional ambiental e ao sistema BIM.

Antes de examinar o uso do desenho arquitetônico nos dias atuais, temos que acompanhar as transformações e a evolução da representação de projeto na perspectiva histórica. Podemos observar que o uso do desenho no contexto histórico está associado às transformações culturais e sociais da prática da profissão de arquiteto. Desde a Alta Idade Média, mudanças de representações gráficas de projeto através da introdução do desenho de plantas baixas, cortes e fachadas resultaram subsequentemente em mudanças na forma que a arquitetura é produzida.

No Egito podemos encontrar os primeiros vestígios do desenho na construção. Estes povos desenhavam sobre grelhas (grids) e incrustavam em lâminas de rochas os croquis com suas ideias. Os desenhos eram rudimentares. Com o objetivo de orientar as construções foram feitas diversas projeções em escala 1:1, no próprio canteiro de obras, com cordas e estacas. Os desenhos não possuíam as informações necessárias para a construção visto que não informavam a volumetria do projeto. $\mathrm{O}$ mestre de obras desempenhava a função de arquiteto e de construtor. Ele era responsável por planejar, organizar, coordenar e executar as obras (ROBBINS, 1997, p.10).

Existem vários debates sobre as técnicas de desenho usadas pelos antigos arquitetos gregos e romanos. Lothar Haselberger descobriu uma série de esboços de gravuras em pedras para a construção do templo grego em Didyma. Estes desenhos foram usados para elaborar as partes que compunham o templo. Foram desenterrados do templo não apenas desenhos em tamanho real, mas também croquis em escalas reduzidas de elementos como o frontão. Estas técnicas de desenho passaram a serem utilizadas para representar os elementos das fachadas como o frontão triangular, as quais foram desenvolvidas regras de projetação e o uso da geometria para a representação das fachadas mais rebuscadas (ROBBINS, 1997, p.10). 


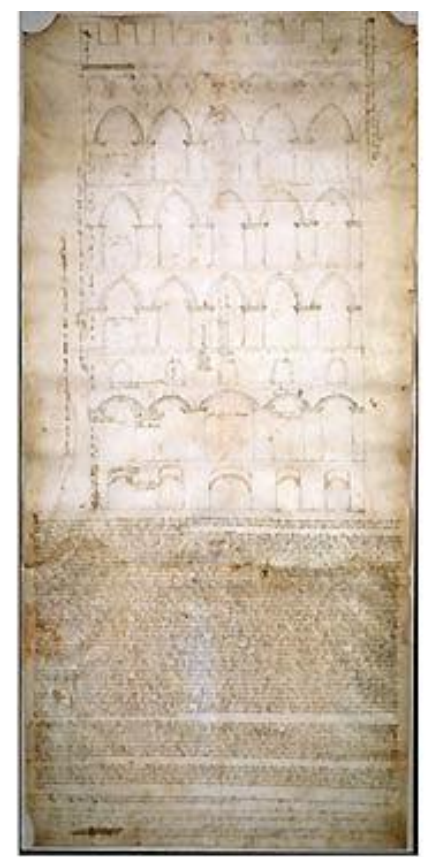

Figura 24: Desenho da fachada do Palácio Sansedoni (1340)

Fonte: MORAIS, 2010

O Renascimento representa um período importante para a arquitetura. Até então os mestres construtores não planejavam todo o edifício previamente. O planejamento de uma edificação era finalizado juntamente com o término da obra, pois as instruções eram transmitidas verbalmente. Assim, a presença do arquiteto era essencial durante todo o período de execução da obra. No Renascimento, o trabalho do mestre construtor sofreu uma grande transformação, pois graças às técnicas de desenho desenvolvidas, os detalhes dos edifícios eram definidos anteriormente à sua execução. Este fato teve grande importância, pois possibilitou maior precisão do projeto que as orientações verbais no canteiro de obras resultando no reconhecimento da profissão de arquiteto.

A transformação do arquiteto de um artesão para um artista foi possível pela nova centralização e importância do desenho como um instrumento crítico de criação e produção da arquitetura. Antes não havia a separação clara entre o ato de projetar e construir. As atribuições do construtor e planejador eram desenvolvidas por um único profissional que permanecia no canteiro de obra durante todo o período da construção (ROBBINS, 1997, p.10-12).

\footnotetext{
"A transformação do papel e status dos arquitetos que começamos a testemunhar nos finais da idade média e que floresceu na Renascença seria associada com maior ênfase ao desenho. Nos séculos seguintes, os arquitetos tornaram-se profissionais distintos com status próprio e papel particular. Devido às mudanças na prática arquitetônica, primeiro empreendidas na Renascença, o desenho fixouse como instrumento dominante do projeto" (ROBBINS, 1997 apud MORAIS, 2010, p.13).
} 
As técnicas que permitiram a representação do projeto são a planta baixa, cortes, fachadas e perspectivas (ROBBINS, 1997, p. 18). O conjunto de desenhos e documentações passaram a ser a principal forma de comunicação entre o arquiteto e o construtor. Estas formas de desenho possibilitaram representar formas tridimensionais em uma superfície bidimensional. A partir da descoberta da perspectiva foi possível representar os ambientes interiores e as vistas exteriores da arquitetura. No entanto essas representações ortogonais apresentam limitações para a compreensão do projeto, cujas razões são claramente explicitadas por Zevi na citação abaixo:

\begin{abstract}
"Na verdade, a planta de um edifício nada mais é que uma projeção abstrata no plano horizontal de todas as suas paredes, uma realidade que ninguém vê a não ser no papel, cuja única justificativa depende da necessidade de medir as distâncias entre os vários elementos da construção, para os operários que devem executar materialmente o trabalho [...]" (Zevi, 1996, p. 18).
\end{abstract}

Apesar de sua contribuição para a arquitetura, essas técnicas de representação bidimensionais não são completas, pois informam principalmente as dimensões e não representam todas as formas e os espaços internos do projeto, e particularmente os seus elementos tais como luzes, sombras, texturas, etc. No entanto a revolução dimensional cubista, sua necessidade de compreender profundamente a realidade dos objetos, conduziu o homem à descoberta da quarta dimensão.

\footnotetext{
“O pintor parisiense de 1912 fez o seguinte raciocínio: eu vejo e represento um objeto, por exemplo... uma mesa; vejo-o de um ponto de vista e faço o seu retrato nas suas três dimensões a partir desse ponto de vista. Mas se... caminhar ao redor da mesa, a cada passo mudo o meu ponto de vista, e para representar o objeto desse ponto devo fazer uma nova perspectiva. Consequentemente, a realidade do objeto não se esgota nas três dimensões da perspectiva; para possuí-la integralmente eu deveria fazer um número infinito de perspectivas dos infinitos pontos de vista. Existe, pois, outro elemento além das três dimensões tradicionais, e é precisamente o deslocamento sucessivo do ângulo visual. Assim designou-se o tempo, 'quarta dimensão'.” (Zevi, 1996, p. 20-22)
}

As técnicas ortogonais de desenho existentes na época de Zevi e até hoje são incapazes de suprir todas as necessidades de informações do projeto. Visto que a arquitetura não é apenas o resultado de um conjunto de largura, comprimento e altura, mais sim do contraste entre cheios e vazios, espaços internos e externos, é o espaço que vivenciamos e percorremos proporcionando inúmeros pontos de vista.

Vivemos e trabalhamos em um mundo tridimensional, mas grande parte dos softwares utilizados em arquitetura ainda utiliza as representações bidimensionais, ou o chamado "Sistema CAD 2.1/2 D". Estes foram os primeiros sistemas bidimensionais a evoluir para incorporar alguns recursos tridimencionais que consistem na extrusão de superficies bidimensionais, sem usufruir de todas as vantagens que a representação 
tridimensional oferece. Estes softwares não modelam geometrias complexas, pois não possuem recursos para modelar superfícies curvas em duas direções o que impõe restrições formais ao projeto. Além de não suportarem rederização (que é o processo de gerar uma imagem de um modelo digital) de alta qualidade e não calcularem com precisão a iluminação natural e artificial ocasionando redução da realidade (RAMIREZ et al, 2009, p. 4).

Devido ao avanço tecnológico computacional das últimas décadas, tem início a elaboração de imagens geradas em softwares de modelagem tridimensional, permitindo a construção de perspectivas virtuais, simulando a realidade, sem a necessidade de um modelo em tamanho natural. O que tornou possível a execução do "deslocamento sucessivo do ângulo visual" através das animações de percursos computacionais.

A modelagem tridimensional, descritas por ZEVI (1996), além de representar as quatro dimensões que são largura, altura, profundidade e tempo possibilitam a novas técnicas e recursos. Entre estas novas técnicas podemos citar os passeios virtuais internos, a animação de objetos, a animação solar, o cálculo de iluminação global, a projetação de geometrias complexas não-euclidianas (como por exemplos, malhas, "nurbs", etc.), a fabricação digital e customização em massa (RAMIREZ et al, 2009, p. $4)$.

A introdução de ferramentas digitais voltadas para projetação tridimensional ajudou o arquiteto na tomada de decisão, pois permite uma visão holística. Nesse ambiente é possível visualizar forma e espaço, assim como texturas, contrastes e cores, enquanto são explorados os movimentos espaciais e temporais. Utilizando esta nova tecnologia o arquiteto passa a contar com uma ferramenta para experimentação e busca de melhores soluções para o projeto. Como consequência dessa prática, surgiram formas mais inovadoras, mais complexas e livres (KALISPERIS, 1996, p. 3). Essa tecnologia libertou a arquitetura das formas confinadas e das estruturas rígidas.

A utilização da tridimensionalidade permite um maior entendimento do espaço, da altura, profundidade, massa, os quais resultam na forma do objeto. É preciso utilizar ferramentas que possibilitam explorar as diferentes formas e descobrir qual a mais apropriada para cada projeto. Segundo KALISPERIS (2007), os computadores deveriam ser utilizados para esboços, exploração e geração de formas e não para simples representação e documentação final do objeto a ser construido.

É necessário que os laboratórios de projetação sejam compostos de ambientes com uma associação e entendimento entre o homem e a máquina. KALISPERIS ironiza 
a percepção de que "os laboratórios de computação gráfica são um mal necessário". O projeto deve ser desenvolvido em ambientes que possam acomodar computador (meio digital), papel (meio tradicional) e maquetes físicas. Além disto, é preciso também, que, qualquer que seja o software utilizado para projeto de arquitetura, seja capaz de lidar com a estabilidade estrutural e sistemas construtivos: Modelagem x Esboço / Físico x Virtual (http://www.vitruvius.com.br/revistas/read/arquitextos/07.084/247 Acessado em maio de 2012).

\subsection{EVOLUÇÃO DO SISTEMA CAD}

O CAD (Computer-Aided Design) significa projeto auxiliado por computador, que consiste em uma nova tecnologia que utiliza o computador como mídia no processo de projetação. O sistema CAD modificou significativamente a forma de projetar. Antes do $\mathrm{CAD}$, todo desenho produzido era feito com lápis ou nanquim no papel. Modificações pequenas no projeto significavam apagar o desenho e redesenhar, contudo quando ocorriam mudanças mais significativas era necessário fazer outro desenho. Caso a modificação em um desenho afetasse outros documentos, todos os desenhos teriam que ser manualmente desenhados novamente.

Os sistemas CAD surgiram nos anos 60, quando Ivan Sutherland, do Instituto de Tecnologia de Massachusetts (MIT), desenvolveu o sistema SKETCHPAD durante o seu curso de Doutorado (PhD). O Sketchpad foi desenvolvido no laboratório MIT's Lincoln em um computador TX-2 que era muito avançado para época. Utilizava o desenho como meio de comunicação onde projetista poderia interagir graficamente com o computador.

O software possuía entradas e saídas e programa que permitia interpretações de informações obtidas diretamente da tela do computador através de uma caneta específica, ou seja, operação em tempo real, cuja resposta era simultânea aos comandos do operador. Aquela caneta especial "light pen" era usada para desenhar diretamente no monitor do computador e incorporava técnicas de interfaces gráficas como unir linhas, a ferramenta "zoom" e o desenho com precisão vetorial. Também permitia que fosse definido um desenho mestre ("master drawing") a partir do qual seriam criados outros desenhos. Cada um dos desenhos secundários seria semelhante ao desenho mestre e caso este fosse alterado, todos os outros seriam alteradas da mesma forma. As idéias implementadas no Sketchpad foram o ponto de partida para a tecnologia dos sistemas CAD. O Sketchpad foi utilizado em desenhos elétrico, mecânico, científico, matemático e animações (Sutherland, 2003, p.9). 


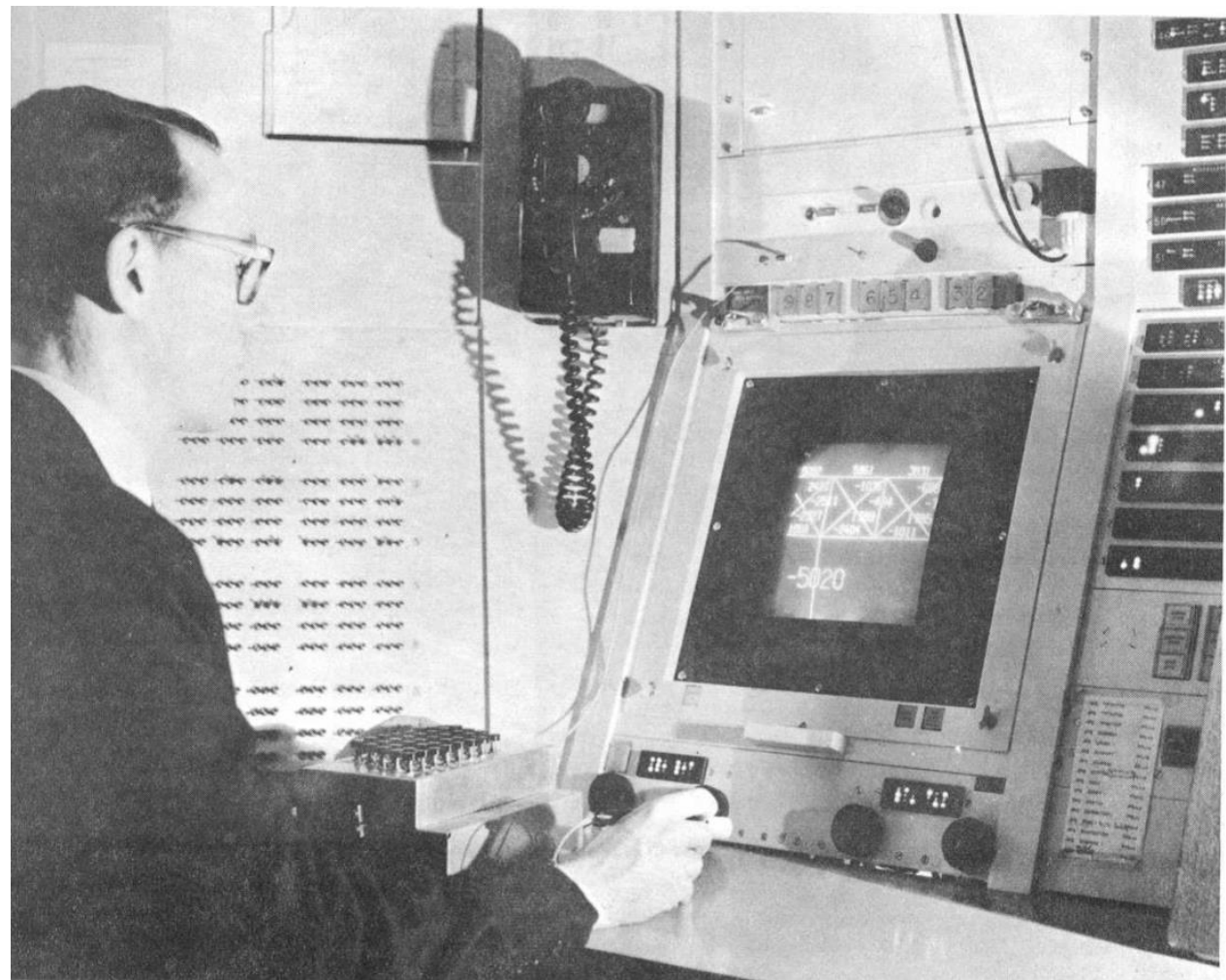

Figura 25: Utilização do Sketchpad Fonte: Sutherland, 2003

Na mesma época foram desenvolvidos projetos paralelos similares ao Sketchpad na ITEK e General Motors. O projeto da ITEK era chamado "The Electronic Drafting Machine" (máquina eletrônica de desenho) e usava o computador PDP-1 da Digital Equipment Corporation, um vetor de exibição renovado e um disco de memória amplo utilizado para atualizar a exibição gráfica. Os comandos de entrada eram operacionalizados pela caneta eletrônica (“electronic light pen”). Enquanto isso no laboratório de pesquisa da General Motors em 1960, o Dr. Hanratty foi o co-autor do DAC (Design Automated by Computer), o primeira sistema de manufatura de produção de gráficos interativos. (Disponível em: http://www.mbdesign.net/mbinfo/CAD1960.htm Acessado em 18/04/2014).

$\mathrm{Na}$ transição de um sistema a outro é necessário um período de adaptação e maturidade, para que alcance uma prestação de serviço ótima ou aceitável. Não podemos pensar que da noite para o dia um sistema funcionará com toda sua capacidade. Portanto as transformações do desenho assistido por computação foram acontecendo de forma gradual juntamente com a evolução da computação. 
Em 1960 foi fundada a companhia McDonnell Douglas Automation CompanyMcAuto que teve papel importante no desenvolvimento do CAD com a introdução do programa CADD desenho auxiliado por concepção e elaboração (Computer Aided Design and Drafting). (Disponível em: http://www.mbdesign.net/mbinfo/CAD1960.htm Acessado em 18/04/2014).

As aplicações iniciais do CAD produzidas pelo professor Charles Eastman na Universidade Carnegie-Mellon, utilizava algoritmos simplificados em duas dimensões, depois em três dimensões. O sistema de construção descritiva dos edifícios e um acervo de várias centenas de milhares de elementos arquitetônicos que podem ser montados e desenhados na tela do computador em uma concepção de desenho detalhado (Disponível em: http://www.mbdesign.net/mbinfo/CAD-History.htm Acessado em 18/04/2014).

A tentativa mais significativa de criar um sistema CAD comercial foi feita pela Control Data Corporation's Digigraphics, que era sucessora da ITEK anteriormente mencionada . O sistema custou meio milhão de dólares e foram vendidas poucas unidades.

Em 1968 Donald Welbourn Diretor da Cooperação Industrial na Universidade de Cambridge, teve a ideia de usar o computador com o objetivo de simular padrões para solucionar problemas de modelagens complexas tridimensionais. Os trabalhos iniciais foram financiados pela Ford, mas a mobilização de recursos para investimento era uma preocupação contínua para Donald Welbourn. Apenas seis anos depois ele conseguiu obter patrocínio do Control Data na Alemanha, e Delta Engineering Group. (Disponível em: http://www.mbdesign.net/mbinfo/CAD-History.htm Acessado em 18/04/2014).

Em 1969 a companhia MAGI foi fundada e lançou o Syntha Vision considerado, por muitos, como o primeiro programa sólido comercializado.

No início da década de 70 várias outras companhias começaram a oferecer sistemas informatizados de concepção e elaboração de desenho. Em 1970 M\&S Computing foi fundada e mais tarde transformada em Intergraph. No início era uma companhia de consultoria que apoiava agências públicas na utilização de tecnologia digital. Entre estas tecnologias estavam incluídas uma orientada para aplicação que tinha interface de comunicação com usuário usando linguagem de aplicação em vez de terminologia de programação. O primeiro sistema de computação gráfica da empresa Intergraph foi usado pelo governo federal dos EUA para desenho de placas de circuito impresso (printed circuit boards). (Disponível em: http://www.mbdesign.net/mbinfo/CAD-History.htm Acessado em 18/04/2014). 
Provavelmente a característica mais forte dos anos 70 é a consolidação do CAD tanto em termos teóricos como metodológicos. A disponibilidade de textos introdutórios e aumento de pesquisas nesta área atraiu maior atenção e atividades. A consequência mais importante disso foi desenvolvimento de enfoques diferentes e automação do desenho. Através da convergência de diferentes enfoques, as técnicas e ambições do CAD aparecem de forma coerente e compreensiva, abrangendo todos os componentes, etapas e aspectos do desenho e construção arquitetônica (KOUTAMANIS, 2005, p.632).

Em 1977 foi criado o CATIA (Computer-Aided Three-Dimensional Interactive Application) por Avions Marcel Dassault. Foi o primeiro software de modelagem tridimensional para a indústria aeronáutica. Posteriormente outros sistemas CAD surgiram como o RUCAPS, TriCad, CALMA e GDS contudo era difícil aplicar a tecnologia tridimensional, pois os computadores eram muito lentos e os custos muito elevados (EASTMAN et al, 2008, p.27).

$\mathrm{Na}$ década de 80, o CAD tornou-se uma área reconhecida, contudo seus softwares eram utilizados apenas para substituir a produção manual de desenhos bidimensionais por processos informatizados.

A Autodesk criou o software Autocad em 1982, que inicialmente foi escrito para vários sistemas operacionais, sobretudo para a arquitetura $\mathrm{CP} / \mathrm{M}$, mas também para o $\mathrm{MS}$ DOS e Unix. O objetivo da companhia era usar a plataforma dos PCs, lançados quase simultaneamente pela IBM, para tornar o AutoCAD conhecido e acessível aos usuários. Posteriormente a Autodesk desenvolveu novas versões do Autocad e outros softwares de modelagem tridimensional para os mercados globais (HTTP://usa.autodesk.com acessado em 05/05/2012).

Nos anos 90, com o surgimento de computadores mais potentes e acessíveis, os sistemas passaram a permitir novos avanços como a modelagem de superfícies, modelagem de sólidos e comunicação entre os softwares.

A modelagem de superfície pode ser definida como um invólucro que não tem massa ou volume, ou seja, não representa sólidos verdadeiros, mas apenas espaço vazio delimitado por superfícies. A maioria dos primeiros sistemas CAD pertenceu a esta categoria (RAMIREZ et al, 2009, p. 4).

O modelador de superfície é formado a partir de pontos, linhas, bordas e faces localizadas por coordenadas em um sistema cartesiano tridimensional. Podem ser visualizadas através de estrutura de arame ("wireframe") ou por renderização (KELOW, 2000 apud MARTINS, 2011, p. 31). 
A renderização gera superfícies que representam imagens realísticas com efeito de luz, sombras, cores e texturas. No entanto, os modelos em "wireframe" representam os objetos tridimensionais apenas com vértices e linhas de bordas que podem ser retas ou curvas. Estes modelos proporcionam a criação de documentação que pode servir de dados iniciais para análise do projeto estudado. Contudo, eles possuem limitações significativas quanto a representações de geometrias complexas.

O Sistema de CAD que utiliza volumes sólidos como suas primitivas são conhecidos como modeladores de sólidos. A estrutura de dados de um modelador de solido é mais complexa que sistemas que trabalham com linhas ou pontos em virtude da necessidade de acompanhar as sucessivas associações das diferentes formas primitivas entre si. As relações não são apenas entre arestas e suas extremidades, ou entre superfície e sua aresta, mas também entre os sólidos e as superfícies que os define (MITCHELL, 2008, p. 62).

Os modeladores de sólidos modelam entidades tridimensionais como sólidos reais com volume e massa. Possibilitam a representação de qualquer tipo de curva cujo modelo pode ser enviado para qualquer máquina do tipo $\mathrm{CNC}$ (computer numerical controled) para fabricação digital. Estes sistemas recorrem a representações facetadas e curvas reais para modelar geometrias não-Euclidianas. Proporcionam renderizações precisas e mais realistas que os modeladores de superfície. Os modeladores de sólidos demanda maior coordenação de informações, que, por sua vez, demandam mais memória e mais capacidade computacional (RAMIREZ et all, 2009, p. 4).

\footnotetext{
"Os modelos sólidos possuem nível mais elevado de completude de representação geométrica do que as correspondentes imagens "bitmapped" (matriciais), desenhos vetoriais bidimensionais, modelos em arame e modelos de superfície" (MITCHELL, 1994, p. 268).
}

Mitchell discorre a superioridade da modelagem de sólidos sobre a modelagem de superfície e os desenhos vetoriais bidimensionais. O modelo sólido é mais completo que os outros tipos, pois, por possuir centro de gravidade e massa possibilita quaisquer tipos de geometria. Além disso, representa curvas reais e não somente facetadas, que é ideal para a modelagem de formas complexas e têm trazido novas soluções arquitetônicas. Podemos dizer que a maioria dos modeladores de sólidos também permite modelar superfície, no entanto, os modeladores de superfície não modelam sólidos e frequentemente só representam curvas facetadas (RAMIREZ et al, 2009, p. 4).

O desenvolvimento de softwares e computadores mais sofisticados possibilitou modelar tridimensionalmente por meio do computador e, consequentemente, surgiu a 
Arquitetura Digital. Segundo a citação abaixo, a nova arquitetura foi marcada pelo surgimento de projetos com formas ousadas e complexas, que antes eram difíceis de serem representadas e projetadas.

\footnotetext{
"Uma nova arquitetura está emergindo da Revolução Digital, uma arquitetura que encontrou sua expressão em formas curvilíneas de alta complexidade que, pouco a pouco, vão se incorporando às principais tendências" (KOLAREVIC, 2003, p. 4).
}

O modelo virtual interativo tridimensional não é apenas o equivalente a um modelo físico, ele é um modelo em escala real (1:1) que representa as quatro dimensões: largura, altura, profundidade e tempo, cuja ausência e necessidade foi detectada por Zevi ainda em 1948, data da publicação original de seu livro em italiano, posteriormente traduzido para outras línguas inclusive a portuguesa.

Esta modelagem permite muitas possibilidades que não são proporcionadas por maquetes ou qualquer outra representação tradicional, entre elas podemos citar os passeios virtuais internos e interativos em tempo real, a animação de objetos, a animação solar, o cálculo de iluminação global, o projeto de geometrias complexas nãoeuclidianas, a fabricação digital e customização em massa.

O modelo virtual interativo, animação solar e cálculo da iluminação global foram fundamentais para tornar possíveis as simulações computacionais ambientais. Através do modelo virtual interativo é possível visualizar a trajetória do sol durante o dia e meses do ano. Os softwares de simulação ambiental individual também fazem o cálculo do ofuscamento das edificações vizinhas, análise do acesso solar, fluxo dos ventos para melhor orientar a forma e posicionamento das edificações.

Apesar de todo o avanço tecnológico, atualmente no Brasil os sistemas CAD bidimensionais ainda são muito utilizados para representação e documentação. Uma possível explicação para isto é a falta de uma revisão curricular nas universidades, atualização dos profissionais da área ou a resistência natural a mudanças, que podem constituir temas de pesquisas futuras (MARTINS, 2011, p. 39).

\section{2- MODELAGEM PARAMÉTRICA}

A definição de modelagem paramétrica é central para o entendimento dos sistemas BIM. A ideia de parametrização é que instâncias de formas e outras propriedades podem ser definidas e controladas conforme uma hierarquia de parâmetros pré-definidos. Está instância de um elemento pode variar conforme os valores de seus parâmetros e relações contextuais. (EASTMAN et al, 2008, p.29). 
A parametrização permite que a arquitetura seja definida por meio de especificações e regras de posicionamento, proporções dos seus elementos e interações entre os mesmos. Contudo, grande parte dos projetistas continua utilizando métodos tradicionais para a geração de forma e utilizando o computador apenas como suporte, não aproveitando o grande potencial para gerar tarefas repetidas. (MICHEL, 2008, p.8)

A utilização ferramentas paramétricas computacionais teve inicio na indústria automobilística, naval e aeroespacial para coordenar e conectar projeto e construção. $\mathrm{O}$ emprego desta tecnologia nas indústrias consistiu na reinvenção da forma de conceber os produtos. Assim, a parametrização permitiu que o objeto fosse desenvolvido e avaliado em um ambiente virtual, onde a partir do modelo digital computacional é possível extrair todas as informações necessárias para fabricação dos componentes dos objetos (ANDRADE, 2012 apud KOLAREVIC, 2001, p. 8).

Esta experiência na indústria contribuiu no avanço do processo de projetação, fabricação e construção na arquitetura. Permitiu o desenvolvimento de novos conhecimentos no processo de projetação, análise, fabricação e montagem do edifício. Assim os componentes da edificação podem ser confeccionados fora do canteiro de obra. O Museu Guggenheim de Frank Gehry jamais poderia ser construído sem o aço local e a indústria naval (ANDRADE, 2012 apud KOLAREVIC 2001, p.8).

A modelagem paramétrica computacional baseada em objetos surgiu originalmente em 1980. Possuía como característica a representação de objetos por parâmetros e regras que determinava a geometria, algumas propriedades e características não geométricas. Os parâmetros e as regras permitem que os objetos sejam atualizados automaticamente de acordo com o controle do usuário ou mudanças de contexto. As empresas responsáveis por softwares com o sistema BIM predefiniram um conjunto base de famílias de objetos para os usuários que podem ser modificadas ou acrescidas. Além disto, estas empresas devem fornecer ao usuário a capacidade de desenvolver objetos paramétricos de acordo com sua necessidade de projeto (EASTMAN et al, 2008, p.25).

\footnotetext{
"As ferramentas BIM atuais variam de muitas maneiras: na sofisticação de seus objetos base predefinidos; na facilidade com que usuários podem definir novas famílias de objetos; nos métodos para atualizar os objetos; na facilidade de uso; nos tipos de superfícies que podem ser utilizados; nas capacidades de geração de desenhos; na habilidade de manipular um grande número de objetos e em suas interfaces com outros softwares" (EASTMAN et al, 2008, p.25).
} 
Os sistemas BIM modificaram a forma por meio da qual os projetistas e construtoras visualizam o processo de projetação desde o estudo preliminar até a documentação da construção e a gestão do edifício após a construção. Com o uso do sistema BIM é criado um modelo sólido tridimensional paramétrico que gera automaticamente as tradicionais representações abstratas como planta baixa, cortes, fachadas e plantas de detalhamentos.

Nestes sistemas o desenho não é a coletânea de linhas coordenadas manualmente, mas a representação interativa do modelo computacional. Trabalhar em uma estrutura baseada em um modelo único garante que modificações em uma vista ou um elemento do projeto significam consequentemente alterações automáticas em todo o modelo. Os sistemas BIM adotam modelos paramétricos de elementos construtivos de uma edificação e permite o desenvolvimento de alterações dinâmicas no modelo gráfico que refletem em todas as pranchas e tabelas do projeto. Assim diminui os erros por falta de compatibilização entre os desenhos bidimensionais e o projeto modelado (KRYGIEL e NIES, 2008, p. 27).

\begin{abstract}
"No projeto paramétrico, ao invés de se projetar uma representação de um elemento construtivo como uma parede e uma porta, o projetista define uma família de modelos ou uma classe de elemento, que é um conjunto de relações e regras para controlar os parâmetros, através das quais cada elemento informado pode ser gerado, variando de acordo com seu contexto. Os objetos são definidos usando parâmetros envolvendo distancias, ângulos e regras do tipo: unido a, paralelo a, distante de. Estas relações permitem que cada instância de uma classe de elementos varie de acordo com a configuração de seus próprios parâmetros e ralações contextuais" (EASTMAN et al, 2008, p.29).
\end{abstract}

Portanto, a exemplo da citação acima sobre os recursos de parametrização, o banco de dados nos sistemas BIM vai além do modelo único tridimensional, são informações que incluem os atributos, comportamentos e inter-relação dos elementos arquitetônicos.

A modelagem paramétrica desempenha outro papel importante que é o suporte à concepção e desenvolvimento do projeto de formas não convencionais. Permite o emprego de recursos que facilitaram o controle matemático das representações, transformações e análises de geometrias complexas. Essas particularidades têm causado impacto na produção arquitetônica, que vem despontando novas formas através do estudo de superfícies curvas e capacidade de explorar diferentes configurações geométricas cada vez mais complexas (FLORIO, 2009, p. 572). 


\section{3- OS SISTEMAS BIM}

A Modelagem da Informação da Construção é um conceito em desenvolvimento e se transforma de acordo com as novas potencialidades da tecnologia e habilidade dos usuários de manipulação e exploração e uso da mesma. Por isto é difícil vincular o sistema BIM a uma única e simples definição (EASTMAN et al, 2008, p.13).

Segundo a definição fornecida pela M.A. Mortenson Company os sistemas BIM tem suas origens nas pesquisas sobre projeto assistido por computador de décadas atrás, mas não possui uma definição única e amplamente aceita. Consideram que os sistemas BIM são uma simulação inteligente da arquitetura e possuem seis características principais:

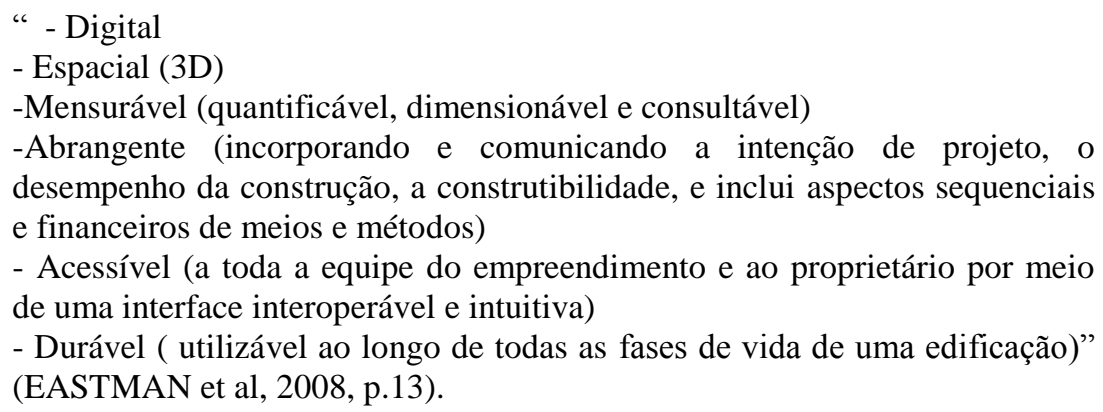

Para EASTMAN et al (2008), os sistemas BIM são definidos como uma tecnologia de modelagem e um conjunto associado de processos para produzir, comunicar e analisar modelos de construção. Estes modelos de construção são caracterizados como:

\footnotetext{
"Componentes de construção, que são representados com representações digitais inteligentes (objetos) que "sabem" o que eles são, e que podem ser associados com atributos (gráficos e de dados) computáveis e regras paramétricas.

Componentes que incluem dados que descrevem como eles se comportam, conforme são necessários, para análises e processos de trabalho, por exemplo, quantificação, especificações e análise energética.

Dados consistentes e não redundantes de forma que as modificações nos dados das componentes sejam representadas em todas as visualizações dos componentes.

Dados coordenados de forma que todas as visualizações de um modelo sejam representadas de maneira coordenada" (EASTMAN et al, 2008, p.13).
}

Ao modelar um projeto em sistemas BIM trabalhamos com componentes da construção e seus atributos e não apenas com formas geométricas e linhas. Todos os componentes da construção estão associados por meio de regras paramétricas com gerenciamento de informações além dos dados geométricos. Modificações em atributos do projeto são automaticamente refletidas em todo o projeto, como vistas, fachadas, cortes e plantas. Sendo possível gerar dados qualitativos e quantificar materiais da 
construção visto que no processo de projetação são inseridas as informações dos materiais utilizados para a construção da edificação. Além disto, permite antecipar o comportamento da edificação por meio de simulações.

KRYGIEL \& NIES (2008) afirmam que se trata da informação sobre toda a edificação além de um conjunto completo de documentos referentes ao projeto armazenados em uma base de dados totalmente integrada. Todas as informações são paramétricas e por isso inter-relacionadas. Assim, os modelos idealizados em sistemas BIM vêm sendo chamados de modelos inteligentes ou "building smarter".

Existe uma falta de entendimento por parte de profissionais e empresas da AEC do sistema BIM. Este sistema envolve comunicação e a colaboração entre os diferentes profissionais e empresas ligadas à AEC. Com esta definição podemos argumentar que atualmente poucas equipes da AEC estão utilizando o sistema BIM de forma adequada. Esta afirmação é comprovada por KIVINIEMI et al. (2008) que demonstram que muitos dos profissionais utilizam softwares BIM como ferramentas de CAD melhoradas, sem alterações no processos de projetação (ANDRADE e RUSCHEL, 2009, p. 77).

A inserção destas ferramentas paramétricas nos escritórios de arquitetura demanda um tempo despendido para treinamento da equipe visto que ocasiona uma mudança de postura no pensamento e prática do projeto de arquitetura, o que naturalmente gera mudança de paradigma. Os profissionais AEC precisam estar envolvidos com essa nova tecnologia e inteirados da mudança.

A implementação do sistema BIM requer ainda a implantação e atualização de hardwares, redes e software. Para o bom aproveitamento dos softwares, é necessário hardware compatível, considerando a dimensão do projeto e seus usos. O investimento em hardware tem o mesmo grau de importância da aquisição do software, portanto devem acontecer simultaneamente.

Outra questão importante na utilização do sistema BIM é que seus modelos são uma construção, ainda que virtual, do objeto arquitetônico. Com essas construções, nos diversos estágios do projeto, podemos quantificar, planejar, coordenar e recuperar informações a qualquer momento da vida do empreendimento. Podemos ainda, verificar interferências, testar alternativas de projeto, ensaiar o comportamento do modelo sob ação de diversos agentes internos e externos.

No sistema BIM a modelagem de um objeto requer que todos os materiais utilizados na construção sejam informados. Ao modelar uma parede no BIM, deve ser informado desde o início que tipo de alvenaria será utilizado, se terá reboco, emboço ou 
pintura. Caso estas informações não sejam apresentadas pelo usuário o sistema irá assumir valores default à revelia do mesmo, todavia estas informações podem ser alteradas ao longo do processo de projetação. Outro diferencial neste sistema é que quando é alterado por alguma razão o pé-direito do projeto a escada que interliga os pavimentos automaticamente se readequara sem necessidade de ajustes manuais.

\subsection{BENEFÍCIOS DE UTILIZAÇÃO DOS SISTEMAS BIM}

Podemos citar como benefícios no uso dos sistemas BIM :

- Visualização antecipada e mais precisa de um projeto;

- Correções automáticas de baixo nível quando mudanças são feitas no projeto;

- Geração de desenhos 2D precisos e consistentes em qualquer etapa do projeto;

- Colaboração antecipada entre as múltiplas disciplinas de projeto como consequência melhoria da cooperação interdisciplinar;

- Extração de estimativa de custo confiável e precisa durante as etapas de projeto;

- Possibilidade de estudo da eficiência energética e sustentabilidade no espaço planejado;

- Redução de esforços redundantes relacionados com a repetição de tarefas de projeto e com as verificações das especificações elaboradas e

- Integração de processos de produção e de gestão documental que resultam numa economia de esforços ao nível administrativo. (EASTMAN et al, 2008, p.13)

Constituem benefícios destes sistemas a visualização tridimensional precisa e principalmente o controle das informações relacionadas aos componentes e suas interrelações. Podemos destacar a integração entre o modelo tridimensional e as representações ortogonais que permitem a geração de múltiplas vistas bidimensionais do projeto. As modificações feitas no projeto são automáticas, pois os objetos são controlados por regras paramétricas que asseguram o alinhamento, posição, linearidade, proporções, com isto não há necessidade do usuário controlar as alterações do projeto nas projeções ortogonais.

"A parametrização permite que o projeto seja desenvolvido e avaliado em
um ambiente virtual, onde a partir do mesmo sejam extraídas todas as 
informações necessárias para fabricação dos componentes" (KOLAREVIC, 2001, p 08).

A precisão das informações permitem a articulação entre todos os componentes da edificação. Desta forma, a compatibilização e o desenvolvimento dos projetos das diversas disciplinas é feita em um único modelo tridimensional. Consequentemente, os sistemas BIM contribuem para diminuir os erros que seriam detectados somente na fase de execução da obra. Reduzem também o prazo da construção do projeto.

Estes sistemas integram desde a representação visual do objeto, sua geometria até as relações entre os atributos ocasionando mudanças no processo de criação do projeto, onde o conhecimento construtivo passa a ser essencial. O processo possibilita a verificação da exequibilidade construtiva das soluções, evitando erros e desperdícios.

No método CAD bidimensional os arquivos são criados individualmente e não existem conexões inteligentes. Os desenhos representam um pedaço separado do projeto que precisa ser atualizado ao longo do processo de projeto podendo gerar erros devido à necessidade de correções manuais do projeto.

Os sistemas BIM fornecem uma abordagem diferenciada, em que, ao invés de vários arquivos, o trabalho é feito através de um único arquivo onde todas as informações são consolidadas e transmitidas em rede a todos os usuários do sistema. As informações são armazenadas em um banco de dados único garantido um modelo consistente. A construção de informações enquanto se modela o projeto consiste em uma nova abordagem no processo de projetação, estudo e análise do projeto que tira proveito da tecnologia computacional disponível. (RIBEIRO, 2010, p. 113)

Os softwares que se baseiam nos sistemas BIM apresentam diferentes características: na sofisticação de seus objetos predefinidos; na facilidade com que usuários podem definir novas famílias de objetos; nos métodos para atualizar e modificar as famílias de objetos; na facilidade de uso; nos tipos de superfícies que podem ser utilizados; nas capacidades de geração de desenhos; na habilidade de manipular um grande número de objetos, na facilidade de extrair desenhos técnicos e em suas interfaces com outros softwares. (EASTMAN et al, 2008, p.26)

\footnotetext{
"A maioria das ferramentas BIM de projeto de arquitetura permitem que o usuário mescle objetos modelados em 3D com seções desenhadas em 2D possibilitando aos mesmos determinar o nível de detalhamento em 3D, mais ainda produzir desenhos completos. Objetos desenhados em $2 \mathrm{D}$ não são automaticamente incluídos em listas de materiais, em análises e outras aplicações possíveis ao BIM . Ferramentas BIM em nível de fabricação, por outro lado, representam tipicamente cada objeto completamente em 3D. O nível de modelagem 3D é uma variável importante entre as diferentes práticas BIM" (EASTMAN et al, 2008, p.26).
} 
Atualmente existem vários softwares que utilizam os sistemas BIM para o desenvolvimento de projetos de arquitetura: Autodesk Revit, a família Graphisoft ArchiCAD, o Bentley Architecture e seu conjunto de produtos associados, e o Digital Project da Gehry Technology, assim como ferramentas em nível de fabricação, como o Tekla Structures, o SDS/2 e o Structureworks.

\subsection{REVIT}

Consideramos a plataforma Revit a partir da perspectiva do Revit Arquitetura. $\mathrm{O}$ Revit é o software mais reconhecido no mercado em projetos de arquitetura que utiliza o sistema BIM. Em 2002 foi introduzido aos produtos Autodesk, após a Autodesk adquirir o Revit de uma empresa "startup". O Revit é uma plataforma separada do AutoCAD, com uma base de código e estrutura de arquivos diferentes. Ele constitui uma família de produtos integrados que atualmente inclui Revit Architecture, Revit Structure e Revit MEP. Podendo ser executado no sistema operacional Windows e instalado em ambos processadores 32 e 64 bits do sistema operacional. (EASTMAN et al, 2011, p.77)

O software Revit foi desenvolvido para trabalhos nos sistemas BIM com o objetivo de capacitar os profissionais de projeto e construção a trazerem as idéias deste conceito à construção com uma abordagem baseada em modelo coordenado e consistente. Ele inclui os recursos de todas as diciplinas da arquitetura em uma interface unificada. A última versão do Revit é a de 2017.

O Revit apoia o desenvolvimento de novos objetos paramétricos e customização de objetos predefinidos. Também suporta as relações hierárquicas entre parâmetros. As regras de definição de objetos tem melhorado a cada nova versão e inclui funções trigonométricas. Assim, um objeto pode ser definido por meio do uso de um grupo de sub-objetos com relações paramétricas. A inserção de API (Interface de Programação de Aplicativos) fornece um bom suporte para o desenvolvimento de aplicativo externo. (EASTMAN et al, 2011, p. 77)

O Revit possibilita também análises antecipadas da construção que auxilia a tomar decisões de melhor solução para o projeto e embasamento de informações desde as fases iniciais. Além da capacidade de realizar análises de luz natural, cálculo de energia e quantitativos de materiais.

O Revit possibilita a importação de modelos do SketchUp, AutoDesSys form•Z, 
McNeel Rhinoceros, Ecotect Analysis, Google Earth ferramenta de desenho conceitual, e outros sistemas que exportam arquivos DXF. (EASTMAN et al, 2011, p.79)

"O Revit Arquitetura suporta os seguintes formatos de arquivo: DWG, DXF, DGN, SAT, DWF/DWFx, ADSK (para componentes do edifício), html (para áreas de relatório), FBX (para vialização 3D), gbXML, IFC, e ODBC (“Open DataBase Connectivity")"(EASTMAN et al, 2011, p. 79).

Os pontos positivos do Revit são a facilidade de apredizagem, interface amigável e grande variedade de bibliotecas disponiveis. Seu suporte bidirecional permite geração e gerenciamento de informações com base em atualizações do desenho e vista do modelo. ((EASTMAN et al, 2008, p.58)

Podemos citar como ponto negativo seu sistema baseado em memória que o torna significantemente mais lento para projetos maiores que 220 megabytes. O REVIT possui limitações nas regras paramétricas que lidam com ângulos. (EASTMAN et al, 2008, p.58)

\subsection{ArchiCAD}

O ArchiCAD é a ferramenta mais antiga que utiliza o sistema BIM para arquitetura disponível no mercado. Começou a ser comercializado no inicio dos anos 1980. A Graphisoft foi adquirida pela empresa Nemetschek, uma companhia de CAD alemã popular na Europa, com enfoque na engenharia civil. O ArchiCAD pode ser utilizado na plataforma MAC e Windows, e posteriormente lançou uma versão Mac OS X (UNIX). (EASTMAN et al, 2008, p.59)

O ArchiCAD possui interface para análise ambiental em gbXML, Ecotect, Energy +, ARCHiPHISIK e RIUSKA.

Possui como pontos positivos uma interface intuitiva e relativamente simples de usar. A biblioteca de objetos possui grande variedade e possibilita a interoperabilidade com outros sistemas. Possui aplicações de apoio na gerência da compatibilização e construção do ciclo de vida do edifício.

Os pontos fracos são algumas limitações na capacidade de modelagem paramétrica, pois não suporta regras de atualizações entre objetos na modelagem ou aplicação automática de operações booleanas entre objetos. O ArchiCAD é um sistema baseado no uso da memória do computador e pode encontrar problemas de escalonamento de grande projetos. No entanto ele pode dividir os projetos em módulos a fim de gerencia-los. (EASTMAN et al, 2008, p.59) 


\subsection{DIGITAL PROJECT DA GEHRY TECHNOLOGY}

Frank Gehry, em 1992, montou uma equipe especializada em suporte tecnológico para suprir as necessidades de suas equipes de projeto. Em 2002, aquela equipe tornou-se uma empresa independente chamada Gehry Technology e presta serviços de modelagens em BIM tanto para atender ao próprio escritório de Frank Gehry como para atender ao mercado.

A customização feita pela Gehry Technologies possibilitou uma adaptação do CATIA da Dassault, que é muito utilizado na indústria aeroespacial e automobilística, para o uso na arquitetura e construção. O Digital Project requer uma estação de trabalho poderosa para elaboração de projeto sendo capaz de lidar com projetos complexos .Um de seus pontos fortes é a grande possibilidade de modelagem paramétrica. (EASTMAN et al, 2008, p.60)

Os pontos fracos são a dificuldade de aprendizado, pois possui uma interface complexa e um alto custo inicial. Além disto, a biblioteca externa é limitada e a capacidade de desenho em arquitetura não é bem desenvolvida. (EASTMAN et al, 2008, p.60)

\subsection{BENTLEY SYSTEMS}

O Bentley Architecture foi introduzido em 2004 sendo um descendente do Triforma. Integrado ao Bentley Architecture estão os módulos Bentley Structural , Bentley Building mechanical systems, Bentley Building Eletrical Systems, Bentley Facilities, Bentley PowerCivil e o Bentley Generative Components. O ponto forte da Bentley é a quantidade de ferramentas de modelagem da construção que lidam com quase todos os aspectos da indústria AEC. Suporta modelagem de superfícies curvas e complexas incluindo o NURBS. Inclui suporte para o desenvolvimento de objetos paramétricos personalizados. Possui plug-in de modelagem paramétrica, o Generative Components, que permite definição e montagem de geometrias paramétricas complexas, usada em vários projetos vencedores de prêmios. (EASTMAN et al, 2008, p.58)

O ponto fraco da Bentley Systems é sua interface não integrada e de difícil aprendizagem. A falta de integração de suas várias aplicações reduz o valor e amplitude de suporte que esses sistemas proporcionam individualmente. E sua biblioteca de objetos é inferior que os produtos similares. 
O Revit Architecture é um dos softwares BIM mais utilizado por escritórios de arquitetura. ANDRADE e RUSCHEL, apud Kiviniemi et al. (2008) descreve dados de uma pesquisa organizada pela Bentley Systems junto a um grupo de profissionais da AEC, em âmbito internacional. Esta pesquisa informa o percentual de arquitetos que usam ou já usaram softwares BIM para o desenvolvimento de projetos de arquitetura. $\mathrm{O}$ resultado indica o Revit Architeture em primeiro lugar com 67\%, o ArchiCAD em segundo lugar com 32\% e o terceiro lugar foi o Bentley BIM que aparece com 15\% (ANDRADE e RUSCHEL, 2009, p. 90).

Para verificação da hipótese proposta nesta dissertação o software utilizado é o Revit Architecture 2016, devido à integração das funcionalidades do simulador ambientais individuais - ECOTECT em sua plataforma. Além das vantagens já citadas no texto a Autodesk disponibiliza licença temporária (três anos) gratuita do Revit para estudantes, existe também a possibilidade de abrir arquivos apenas para visualização sem custos e permite assinatura de curto prazo com menor valor.

\subsection{INTEROPERABILIDADE}

A palavra interoperabilidade tem origem no verbo interoperar, que é a possibilidade de troca de informações entre softwares e sistemas. A interoperabilidade é a condição necessária para a transferência de dados do projeto entre os softwares. A troca de informações entre softwares vem sendo feita desde o final da década de 70 e início dos anos 80 no CAD bidimensional quando o sistema Intergraph era o mais utilizado.

\footnotetext{
“...nenhum programa computacional pode realizar de forma isolada todas as tarefas associadas com o projeto e construção da edificação. A interoperabilidade representa a necessidade de transferir dados entre softwares, permitindo que múltiplos tipos de especialistas e de aplicativos contribuam para o projeto em desenvolvimento"(EASTMAN et al, 2008, p. $65)$.
}

A interoperabilidade possibilita a troca de informações entre os aplicativos e elimina a necessidade de inserir novamente os dados gerados anteriormente e facilita $o$ fluxo de trabalho e automação. Assim como a arquitetura e a construção são atividades colaborativas, também devem ser as ferramentas que a suportam. (EASTMAN et al, 2008, p.66)

A evolução tecnológica permitiu que os softwares de AEC executem diferentes tarefas que envolvem várias fases de projetação. Estes muitas vezes necessitam de trocas de informações durante o ciclo de vida do projeto, da construção e do uso. Contudo, dificuldades na troca da informação, devido à baixa interoperabilidade, 
aparecem como fatores limitantes do uso do BIM no processo de projeto. Para a consolidação do BIM é de grande importância o desenvolvimento da interoperabilidade.

Segundo ANDRADE e RUSCHEL, para uma boa interoperabilidade é fundamental a implementação de um padrão de protocolo internacional de trocas de dados nos aplicativos e nos processos do projeto. Nesta passagem de dados entre aplicativos existem diferentes formatos de trocas, alguns com maior capacidade de interoperabilidade e outros com menor. (ANDRADE e RUSCHEL, 2009 ,p.80)

Eastman afirma que os dois principais modelos de dados de produto de construção são o Industry Foundation Classes (IFC) e o CIMsteel Integration Standart Version 2 (CIS/2). O IFC é voltado para planejamento, projeto, construção e gerenciamento de edificações enquanto que o CIS/2 é mais utilizado para engenharia e fabricação de aço estrutural. Ambos os formatos representam geometria, relações, materiais, desempenho, fabricação e outras propriedades necessárias para o projeto e construção. (EASTMAN et al, 2008, p.65)

O IFC atende a uma grande variedade de áreas da AEC e pode ser utilizado por uma quantidade significativa de aplicativos, contudo muitas vezes apresenta perdas de informações do modelo que podem acontecer tanto na importação quanto na exportação do arquivo no formato IFC. (ANDRADE e RUSCHEL,2009 ,p.88)

A dificuldade na consolidação de um modelo universal confiável para troca de dados está associada a competitividade entre empresas; não compreensão das consequências positivas de utilização de um modelo único, baixa qualidade da interface, e desinteresse dos integrantes da indústria AEC em mudanças no processo de projetação e construção. (EASTMAN et al, 2008, p.167)

Contudo as empresas de softwares desenvolvem seu produto em função da demanda dos usuários. Estes procuram ferramentas que viabilizem a realização de um número cada vez maior de operações diversificadas. Neste cenário e com o aumento na utilização do BIM, existe a perspectiva de uma maior interoperabilidade entre softwares ou a integração de varias funções em uma única ferramenta de análise e projetação.

Assim a interoperabilidade entre softwares do sistema BIM e softwares de simulação ambiental é fundamental. Quando exportamos um modelo tridimensional para um software de simulação ambiental, pode haver uma boa comunicação ou não entre softwares. Estes softwares muitas vezes pertencem a sistemas diferentes e nem sempre a interoperabilidade é integral. 
"Khemlani (2007) mostra, a partir de dados de uma pesquisa realizada pela AECbytes, que o mais importante critério na escolha do BIM é a habilidade de produzir documentos finais de construção, sem precisar de usar outras ferramentas complementares" (ANDRADE e RUSCHEL, 2009, p. 79).

Khemlani (2007) ainda relata que os arquitetos, muitas vezes, limitam suas atividades àquelas que podem ser executadas por um único aplicativo BIM. Tarefas colaborativas e capacidade de exportar e importar arquivos em formatos universais não são critérios significativos para a escolha de aplicativos BIM. (ANDRADE e RUSCHEL, 2009, p. 79). Diante deste contexto é de grande importância a integração das funções dos simuladores ambientais individuais a softwares com plataforma BIM, visto que muitas vezes a interoperabilidade não é integral entre estes aplicativos e o projetista tem o retrabalho de modelar e inserir dados da edificação novamente.

\subsection{APLICAÇÕES DOS SIMULADORES COMPUTACIONAIS AMBIENTAIS INDIVIDUAIS}

Atualmente, existe um número considerável de softwares de simulação da LN disponível como softwares livres, de código aberto ou não, ou como softwares comerciais. Essas simulações podem ser aplicadas em todas as fases do projeto, tendo como principal vantagem a possibilidade de estudos quantitativos e qualitativos, permitindo visualizar a aparência do ambiente e a produção de um modelo fotométrico para a estimativa de suas propriedades luminosas (LIMA,CHRISTAKOU, 2007, p.51).

\footnotetext{
"O projeto de arquitetura pode-se beneficiar com a técnica de simulação da LN, com a qual é possível perceber de forma preditiva e interativa, os espaços que ainda não foram construídos. Podem-se avaliar previamente as condições de conforto visual, computando os diversos níveis de iluminação em diferentes pontos do ambiente, possibilitando que se façam os ajustes necessários. Além disso, podese simular o projeto de iluminação artificial conjugado ao da LN, possibilitando melhora significativa na eficiência energética do edifício" (SILVA e CHRISTAKOU, 2007, p. 256).
}

O primeiro passo para avaliar o ambiente de um determinado espaço é elaborar um modelo geométrico tridimensional que o represente. Este modelo deve possuir informações geométricas em forma de coordenadas cartesianas x, y e z, além de conter informações sobre as propriedades ópticas dos materiais e sobre a fonte de iluminação da cena (SILVA e CHRISTAKOU, 2007, p. 51).

A partir desses dados, uma imagem é produzida como se fosse vista por uma câmera virtual. Existe uma relação direta entre a qualidade das informações 
provenientes da simulação e a qualidade da elaboração do modelo geométrico (CHRISTAKOU, 2004, p.11).

O simulador emprega modelos de iluminação (teorias ou "mecanismos") implementados em algoritmos adequados que devem calcular como a luminosidade está distribuída, como cada objeto é iluminado diretamente e indiretamente, segundo o comportamento físico da luz. Esses resultados são exibidos das mais variadas formas, inclusive como imagens e gráficos (SILVA e CHRISTAKOU, 2007, p. 52).

$\mathrm{Na}$ figura 26 segue um fluxograma apresentando os fatores envolvidos em uma simulação computacional da iluminação:

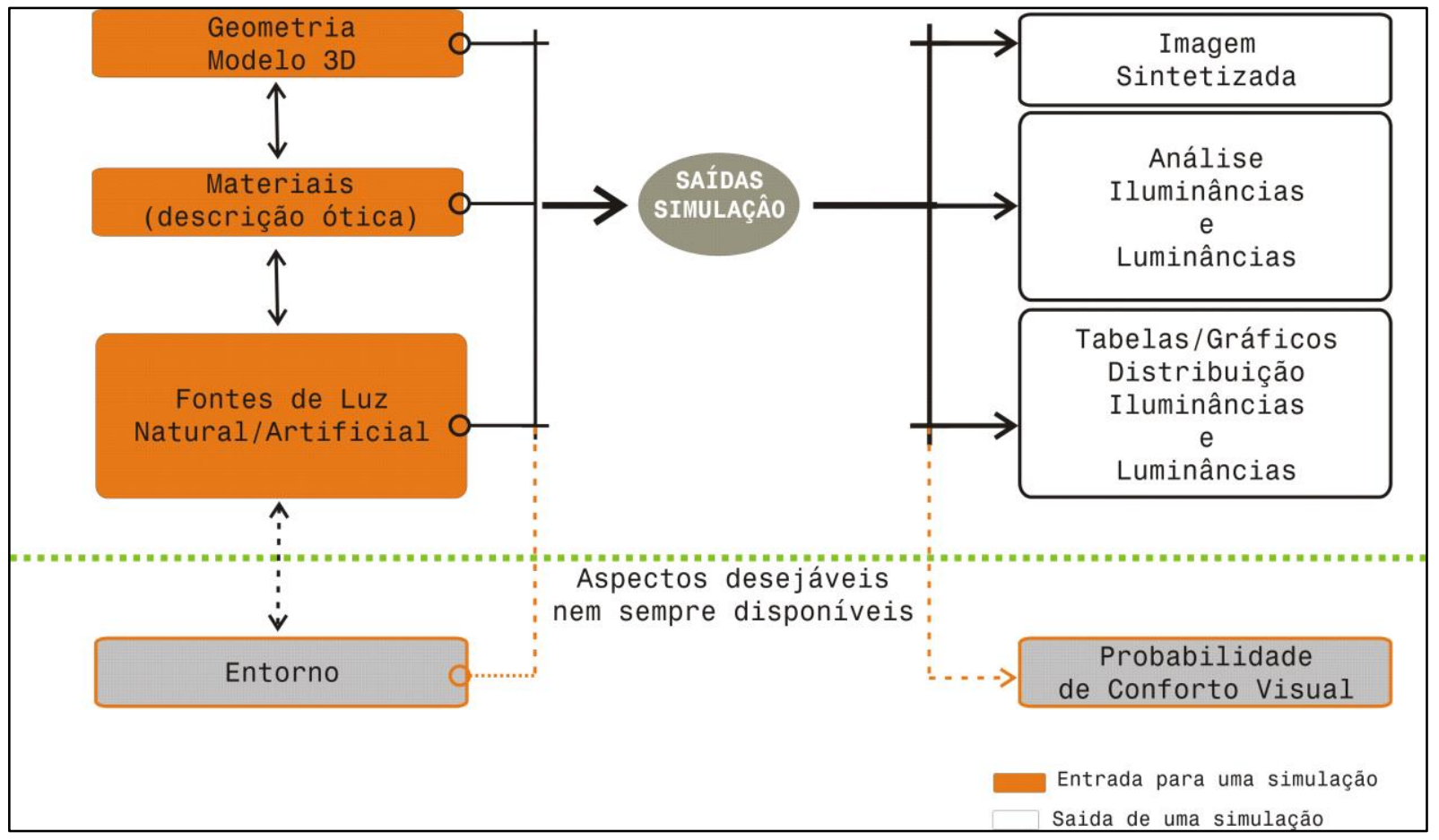

Figura 26- Fluxograma de fatores envolvidos em uma simulação computacional (Fonte: CHRISTAKOU, 2004, p.11)

A coluna da esquerda simboliza os dados de entrada para execução da simulação da iluminação natural, ou seja, os dados que o projetista deve elaborar/inserir no software para obter uma resposta. Os dados de entrada constituem o modelo geométrico tridimensional da edificação ou espaço urbano a ser estudado, as propriedades ópticas dos materiais que serão utilizados, fonte de luz natural e artificial e algumas vezes informações sobre as obstruções do entorno. E os dados de saída obtidos pela simulação que estão localizados na coluna da direita são imagens sintetizadas, análise da luminância e iluminancia, gráficos e tabelas que permitem a elaboração das diretrizes para o conforto visual e térmico. 
O projeto de arquitetura é um processo de sequências de tomadas de decisões. Assim, as decisões tomadas no início da elaboração do projeto, têm impactos decisivos no desempenho ambiental do espaço projetado. A simulação deve estar inserida paralelamente as etapas de projeto nas quais se definem o "partido". Após a definição dos dados geométricos, das informações de materiais, dos componentes da obra e dados geográficos para a construção do modelo em 3D, deve ser analisado se as soluções estão de acordo com os parâmetros estabelecidos. Caso contrário, alguns ajustes podem ser adotados com novas entradas de dados e então processado novamente, até que a solução satisfaça os objetivos pretendidos. Então, volta-se ao processo de elaboração do projeto já em fase do anteprojeto com um grau de certeza suficiente para seguir para a próxima fase. Acrescentamos que o processo de projetação não é linear, podendo retornar a qualquer etapa anterior, até mesmo a concepção (CHRISTAKOU, 2004, p.14).

Cabe ressalvar que existem diferenças entre os programas de "rendering" e programas de simulação. Os softwares de "rendering" têm por objetivo a obtenção de imagens realísticas e agradáveis visualmente, ignorando a precisão do resultado. Por outro lado, os programas de simulação são propostos para reproduzir o comportamento da luz e sua interação com os materiais através de cálculos complexos, fundamentados no fenômeno físico da luz da cena. A principal tarefa dos programas de simulações é permitir a avaliação da qualidade e adequação da solução proposta através de imagens sintéticas e informações numéricas (CHRISTAKOU, 2007, p. 52).

As ferramentas de iluminação utilizam algoritmos chamados de "iluminação global". Estas simulam as propriedades físicas e comportamentais da luz em escala macro (propagação da luz da fonte ao observador) e em escala micro (interação da luz com as características das superfícies) (EHRLICH, apud SILVA e CHRISTAKOU, 2007, p. 52).

\footnotetext{
"As principais aproximações algorítmicas de predição da luz baseiam-se nos modelos de iluminação global que existem basicamente em duas vertentes. Os métodos baseados na cena e que são independentes do ponto de vista do observador- ou simplesmente "scene-based" como o RADIOSITY. E os métodos baseados na imagem e que são dependentes do ponto de vista do observador, "image based", como o RAY TRACING. Ambos são capazes de produzir resultados numéricos além de imagem de alta qualidade, ou seja, avaliação quantitativa e qualitativa da luz natural no espaço arquitetônico" (SILVA e CHRISTAKOU, 2007, p. 52).
}

A tecnologia está tornando a relação custo-benefício mais fácil e acessível para os profissionais a incorporarem o desenho sustentável ao fluxo de trabalho. Estas 
ferramentas de análise ambiental oferecem uma visão antecipada do comportamento e uso da luz natural nos projetos de arquitetura. Planejar, projetar, construir e gerir infraestrutura mais sustentável ajuda a reduzir o impacto da construção tornando a tomada de decisão mais fundamentada para o planejamento do projeto. (Disponivel em: http://usa.autodesk.com/adsk/servlet/pc/index?siteID=123112\&id=17822259 acessado em: junho de 2012).

\subsection{SOFTWARE DE SIMULAÇÃO AMBIENTAL INDIVIDUAL / ECOTECT ANALYSIS}

O software denominado Autodesk Ecotect Analysis 2011 não é mais disponível para compra, em virtude da integração de suas funções ao REVIT. Porém é importante descrever as simulações ambientais realizadas pelo Ecotect inclusive para avaliar está integração.

O Ecotect foi desenvolvido em junho de 2001 pela "Square One Company", tendo sido mais tarde adquirido pela Autodesk, sendo incorporadas as ferramentas de projeto sustentável que compreendem a empresa. Este software permite análise do desempenho e comportamento do edifício no contexto ambiental, auxiliando projetistas na tomada de decisões sustentáveis a partir do conhecimento de fatores e efeitos climáticos como insolação, iluminação, temperatura e sombra.

O Ecotect possui sua própria interface de modelagem. É possível também, importar formas geométricas de outros sistemas CAD via arquivos DXF ou 3DS. Por meio de ligação direta entre o Revit e Ecotect através do arquivo gbXML é possível importar o projeto do Revit para simulação no Ecotect. É raro importar geometrias para o Ecotect e esperar que o programa entenda todas as formas e não necessite de trabalhos adicionais de modelagem. Diferentemente de muitos programas CAD, o Ecotect precisa entender a geometria como um edifício. É a única maneira para que as análises possam ser corretamente realizada. Portanto quando importamos um projeto para o Ecotect é importante verificar cuidadosamente as atribuições dos materiais e sua volumetria (Tutorial ECOTECT, AUTODESK, 2005).

O Ecotect também possibilita obter a distribuição e disponibilidade de radiação solar ao longo de um edifício, ou em um conjunto de edifícios. Isto pode ser útil quando se considera os requisitos de sombreamento ou para avaliar a melhor área para colocar energia fotovoltaica para sua coleta máxima. 
Segundo o manual do software pode-se calcular a distribuição de valores de insolação sobre superfície complexa, caso seja feita de triângulos ou polígonos menores. Normalmente cada superfície tem apenas um valor calculado (tendo em conta o sombreamento parcial). Caso seja necessário uma distribuição mais discreta, basta dividir grandes superfícies planas em múltiplos menores ou substituir a grande superfície com os resultados de um cálculo da subdivisão de superfície.

A execução da simulação ambiental pelo ECOTECT desenvolve a análise dos seguintes parâmetros da edificação:

O Consumo de energia é medido por meio do cálculo do uso total de energia e das emissões de carbono do modelo construído em uma base anual, mensal, diária e horária, utilizando um banco de dados global sobre informações do clima.

Comportamento térmico baseia-se no cálculo da carga de aquecimento e resfriamento e analisa o efeito da ocupação, ganhos internos e de equipamentos.

O consumo de água utiliza como base uma estimativa do uso da água dentro e fora da edificação.

A radiação Solar é feita por meio de cálculo da radiação solar incidente em superfícies e janelas durante qualquer período do ano.

O uso de Luz Natural tem por base o cálculo do fator de luz do dia e níveis de iluminância em qualquer ponto do modelo.

A análise das sombras e luz refletida têm por base o posicionamento do sol para fazer o cálculo das sombras e reflexos relativos ao modelo em qualquer data, hora e local. Mostra como a luz solar entra através das janelas e se movimenta ao longo do espaço (http://usa.autodesk.com/ecotect-analysis/ acessado em 30/03/2013).

\subsection{INTEGRAÇÃO DAS FUNÇÕES DOS SIMULADORES AMBIENTAIS INDIVIDUAIS NA PLATAFORMA BIM}

A construção de edifícios sustentáveis considerando a eficiência energética e menor impacto ambiental é uma realidade. Integrar uma estratégia de simulação ambiental, em um processo de desenvolvimento de projetos nos sistemas BIM é de grande importância na elaboração de projetos. Os sistemas BIM fornecem ao profissional as condições necessárias para analisar um edifício em termos de massa e forma visando otimizar a envoltória e balancear a radiação nos vidros.

Os projetos elaborados nos sistemas BIM podem ser utilizados para estudar formas de reduzir a demanda de energia usando o modelo para calcular a penetração e a 
refletância de luz. Projetos sustentáveis podem influenciar diretamente a produtividade no ambiente de trabalho. Estudos revelam que o uso adequado da luz natural pode aumentar a produtividade e influenciar diretamente no ciclo biológico e humor dos ocupantes. Os avanços dos sistemas BIM estão viabilizando o desenvolvimento de ferramentas necessárias para avaliar comportamento da luz natural e redução do ofuscamento e aquecimento ocasionado pelo sol, comparando custos e requisitos globais do projeto. (EASTMAN et al, 2008, p.104)

"As ferramentas de simulação de modo geral, e, em especial, as de análise da LN através dos softwares de simulação, devem estar integradas na prática de projetação do arquiteto, para que sejam efetivamente importantes. Na verdade, ainda se espera que haja uma transição da ferramenta básica de simulação "stand alone" para uma ferramenta integrada de projeto e simulação" (CHRISTAKOU, 2004, p.23).

Atualmente grande parte dos softwares semelhantemente aos sistemas BIM não incluem simuladores ambientais integrados em sua plataforma. Contudo algumas empresas como a Autodesk estão integrando as funcionalidades do simulador ambiental aos sistemas BIM. Caso o sistema BIM utilizado não disponibilize ferramentas de análise ambiental integrada em sua plataforma, isto pode ser feito exportando o modelo para um software de análise ambiental individual.

Os programas "complementares" são utilizados para aproveitar a informação gerada nos sistemas BIM e realizar os cálculos necessários aos projetos de edificações, como consumo energético, desempenho térmico, acústico e lumínico, cálculos estruturais, de circulação de pessoas e veículos, entre outros. A título de exemplos de softwares de simulação ambiental individual e cálculo energético podemos citar: Autodesk Ecotect Analysis, Autodesk Green Building Studio, IES Virtual Environment e EcoDesign.

O Autodesk Green Building Studio- GBS é um software, oferecido por meio de serviço web que utiliza a solução baseada em nuvem para simulação do desempenho energético e emissão de carbono dos edificios. A Análise Energética de projetos no software Revit utiliza o serviço oferecido pelo Green Building Studio, que viabiliza suporte para estudos e análise de projetos sustentáveis, otimizando a eficiência energética. O GBS pode ser usado como um serviço da Web independente e também possibilita a análise energética do edifício dentro da plataforma do Revit sem a necessidade de exportar o projeto. A análise energética do edifício pode ser realizada 
em qualquer etapa do projeto e construção por meio do $G B S$ (Disponível em: https://gbs.autodesk.com/GBS/. Acessado em 25/03/2016.).

Desde 20 de março de 2015, novas licenças do software de análise ambiental Autodesk Ecotect não estão mais disponíveis para compra. Segundo informações do site da Autodesk as simulações realizadas pelo Ecotect Analysis estão disponíveis no ambiente Revit. Esta mudança permite que a Autodesk transfira recursos, maximizando os esforços de desenvolvimento no sistema BIM e soluções baseadas em nuvem para a construção de análise de desempenho ambiental e visualização dos resultados. (Disponível em: http://usa.autodesk.com/ecotect-analysis/.Acessado em 25/10/2015.)

Todavia usuarios com contrato ativo do software Ecotect continuará a ter acesso aos seus benefícios de acordo com os termos de seu contrato de licenciamento. Isto inclui o suporte e uso de versões anteriores do software até o termino de seus contratos. Podemos destacar ainda que usuarios que compraram o software Ecotect Analysis com manutenção de subscrição continuará a usar sua licença perpétua mesmo após expirarem. (Disponível em: http://usa.autodesk.com/ecotect-analysis/. Acessado em 25/10/2015.)

Nos itens subsequentes estão listandos as principais tarefas realizadas pelo Ecotect e como elas estão sendo incluidas no Revit segundo informações da Autodesk (Disponível em: http://usa.autodesk.com/ecotect-analysis/. Acessado em 25/10/2015).

\subsubsection{ANÁLISE DA LUZ NATURAL}

O Revit agora possui um plug-in da Autodesk, baseado no serviço de nuvem para a análise solar que incorpora um algoritmo mais avançado do que aquele utilizado usado pelo Ecotect. Com este novo plug-in, a análise é totalmente integrada ao Revit. Possibilita visualizar e quantificar a distribuição da radiação solar para qualquer data e hora do ano e apresentar diretamente os resultados no modelo. (Disponível em: http://images.autodesk.com/adsk/files/Ecotect_Frequently_asked_questions.pdf

.Acessado em: 04/04/2016.)

Os plug-in são extensões de programas que podem ser instalados nos software. Podem ser produzidos pelo próprio fabricante do software ou por terceiros. Possibilitam a realização de funções específicas e complementares ao programa original como o cálculo e análises de desempenho da luz natural de edificações.

O Revit também pode executar o cálculo da iluminação natural e elétrica utilizando o plug-in de Análise de Iluminação para o Revit (Lighting Analysis for Revit) 
que foi atualizado em 1 Julho de 2016 para o Insight 360 . No item 6.4 .8 desta dissertação encontra-se maiores informações sobre o plug-in Insight 360. A análise utiliza o serviço de nuvem da Autodesk 360 de renderização para exibir os resultados da luz natural e elétrica diretamente no modelo do Revit. A análise de iluminação para o Revit permite fornecer os dados de entrada da localização, tempo, assim como o modelo de céu. Os resultados são validados em comparação ao Radiance, uma ferramenta de simulação, e exibidos rapidamente. O serviço também oferece uma análise da luz do dia (daylighting) automatizado para LEED (Disponível em: http://www.autodesk.com/products/lighting-analysis-revit/overview. Acessado em: 25/10/2015.).

O "Leadership in Energy and Environmental Design" - LEED é um sistema internacional certificação e orientação para construções sustentáveis em diferentes categorias. O LEED foi desenvolvido pela organização United States Green Building Council e envolve pré-requisitos obrigatórios e um sistema de pontuação que permite obter diferentes classificações para as edificações.

O Revit (2015-2016) disponibiliza recursos para simulação da iluminância. A iluminância é útil para determinar se o ambiente disponibiliza de luz suficiente para executar diferentes atividades. A iluminância é medida em lux ou footcandle (1 footcandle $=10.7$ lux $)$.

\subsubsection{ESTUDOS CAMINHO SOLAR E SOMBRAS}

As ferramentas interativas da trajetoria solar no Revit permitem visualizar os impactos da luz natural e sombras no interior e exterior do projeto em qualquer localização. Esta ferramenta está totalmente integrada com o Revit e pode ser utilizada para fazer um estudo solar a qualquer período do ano, em adição a qualquer horário específico.

Por meio de estudo solar e de sombra, é possível fazer a visualização analítica da luz natural com base na localização, orientação do seu projeto e período do ano. $\mathrm{O}$ caminho solar também pode ser exibido e editado tanto diretamente arrastando o sol ou através do ajuste do período do dia.

O Ecotect e o Revit possuem ferramentas similares para a simulação de caminho solar (Disponível em: http://sustainabilityworkshop.autodesk.com/buildings/ecotectshadows-sunlight-hours. Acessado em 28/03/2016.). 


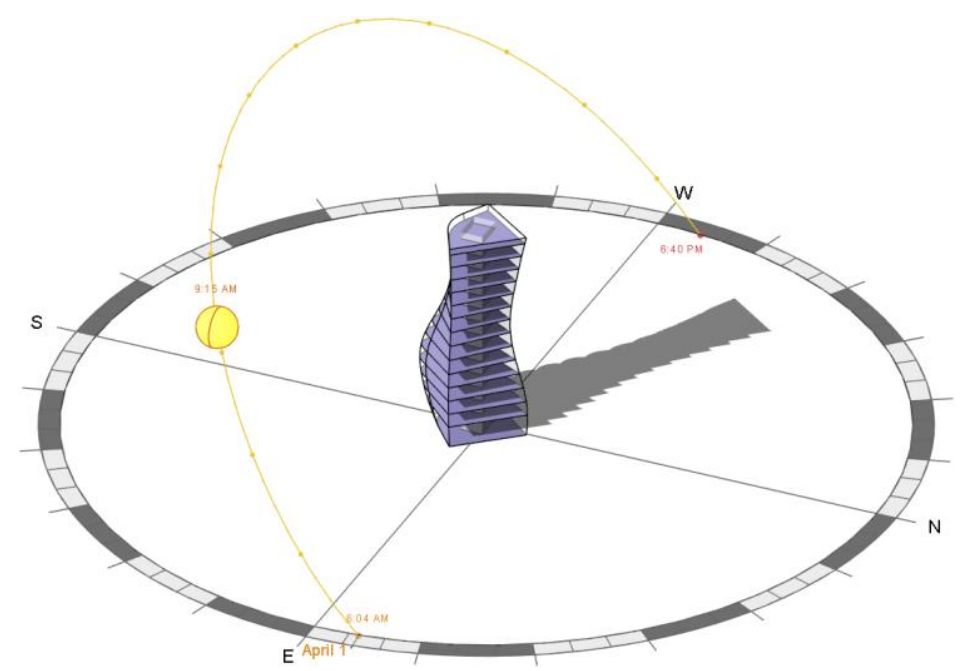

Figura 27: Caminho solar no Revit

Fonte: Krygiel e Vandezande, 2014, p. 441

\subsubsection{DESEMPENHO TÉRMICO}

O Revit inclui um recurso de carga de aquecimento e refrigeração e foi projetado seguindo as especificações da "ASHRAE Handbook of Fundamentals". O “ASHRAE Handbook of Fundamentals" é um manual com os principais fundamentos sobre aquecimento, ventilação, ar condicionado e refrigeração das edificações, elaborado pela sociedade americana de engenheiros.

Podem ser calculadas as cargas térmicas do projeto levando em consideração as cargas internas, "solar stress" e os efeitos da superfície envolvente do edifício. É possível então calcular as cargas de aquecimento e resfriamento para os modelos e analisar os efeitos da ocupação, ganhos internos, infiltração e equipamentos.

\subsubsection{ANÁLISE ENERGÉTICA DO EDIFÍCIO}

A análise de energia integrada no Revit foi aprimorada na versão 2014 para suportar elementos construtivos mais detalhados. O fluxo de trabalho aprimorado cria um modelo de análise de energia diretamente de um modelo Revit, e retorna os resultados dentro do próprio software. A análise é realizada utilizando "Green Building Studio", e permite calcular o uso total de energia e de custos em uma base anual, mensal, diária e por hora, usando um banco de dados global de informações sobre as condições meteorológicas. É possível personalizar a representação visual dos dados obtidos por meio do "Green Building Studio". 


\subsubsection{VISUALIZAÇÃO DE DADOS METEREOLÓGICOS}

A Visualização de dados metereológicos está disponível no Revit desde 2010, e mais recentemente em Formlt. O Autodesk Formlt é um aplicativo web movel que ajuda a capturar a concepção do edificio a qualquer hora e lugar. Utiliza as dados reais da local do edifício para suporte nas decisões do projeto. Importa imagem de satélite da área do projeto (Disponível em: https://autodeskinform.wordpress.com/about/. Acessado em 28/03/2016).

A visualização de dados metereológicos está disponível no Revit, Formlt e "Green Building Studio", além dos arquivos disponíveis para "download" no GBS. Os dados metereológicos são representados nessas ferramentas e fornecidos pela "Autodesk Climate Server", contém aproximadamente um milhão de estações meterológicas virtuais e são baseadas em ciência meteorológica do som e pesquisas (Disponível em: http://images.autodesk.com/adsk/files/Ecotect_Frequently_asked_questions.pdf Acessado em 25/03/2016) A Autodesk Climate Server é parte do serviço web Green Building Studio, tem um vasto banco de dados climáticos.

No Ecotect por meio da ferramenta "Weather Manager tool" é possivel obter dados climáticos do local do projeto. Estes dados também são obtidos pela "Autodesk Climate Server".

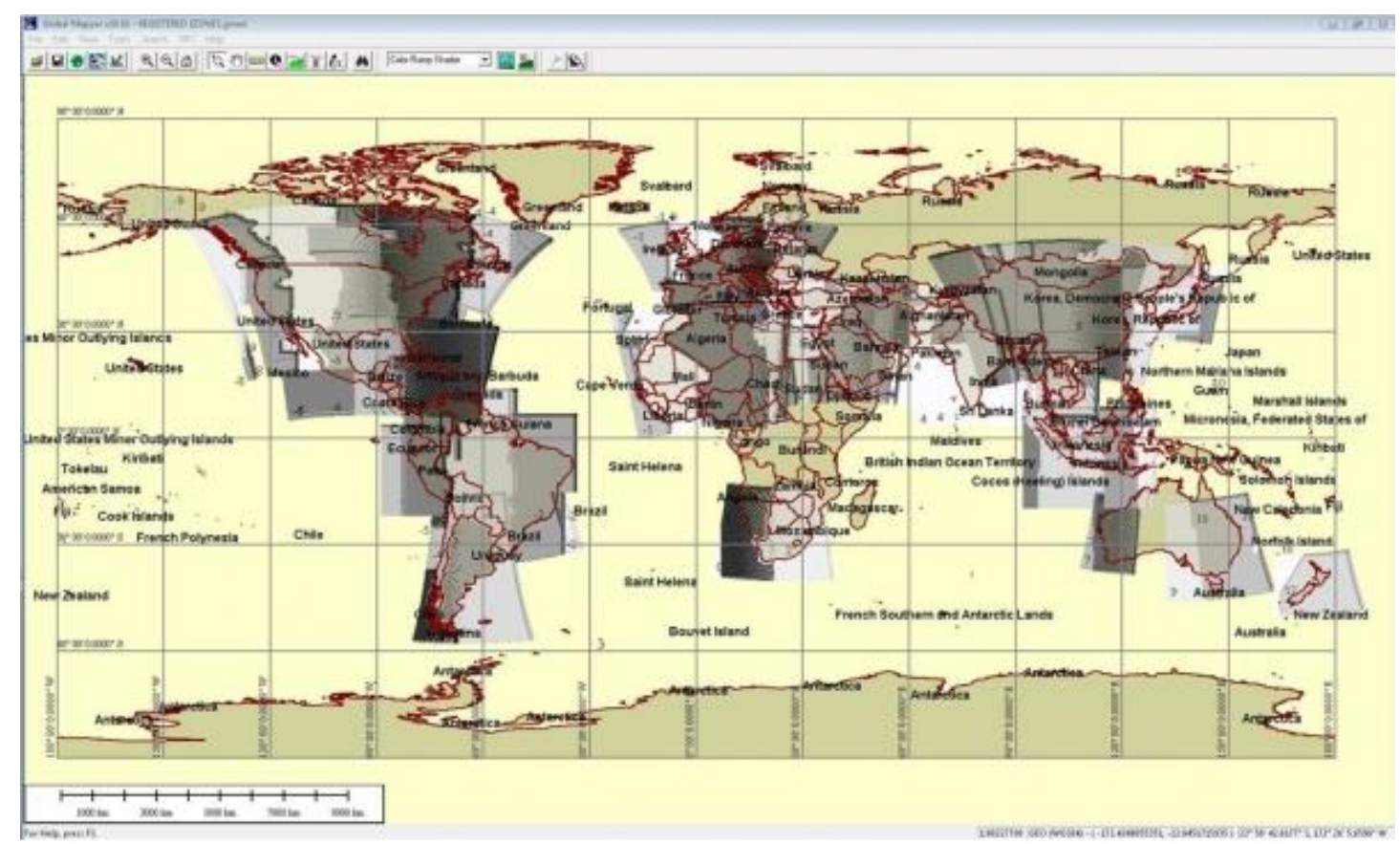

Figura 28: Dados climáticos e localização do Autodesk Climate Server em um mapa global Fonte: http://sustainabilityworkshop.autodesk.com/buildings/sources-climate-data 


\subsection{VEÍCULO DE EXPERIMENTAÇÃO}

No sentido de proceder à verificação da hipótese desta dissertação será utilizado como veículo de experimentação o edifício do Tribunal Superior Eleitoral - TSE, localizado em Brasília, no Setor de Administração Federal Sul (SAFS), Quadra 7, lote 1 e 2. O TSE encontra-se próximo ao Superior Tribunal de Justiça, Tribunal Superior do Trabalho, Tribunal Regional Federal e Avenida das Nações conforme ilustrado na figura 29.

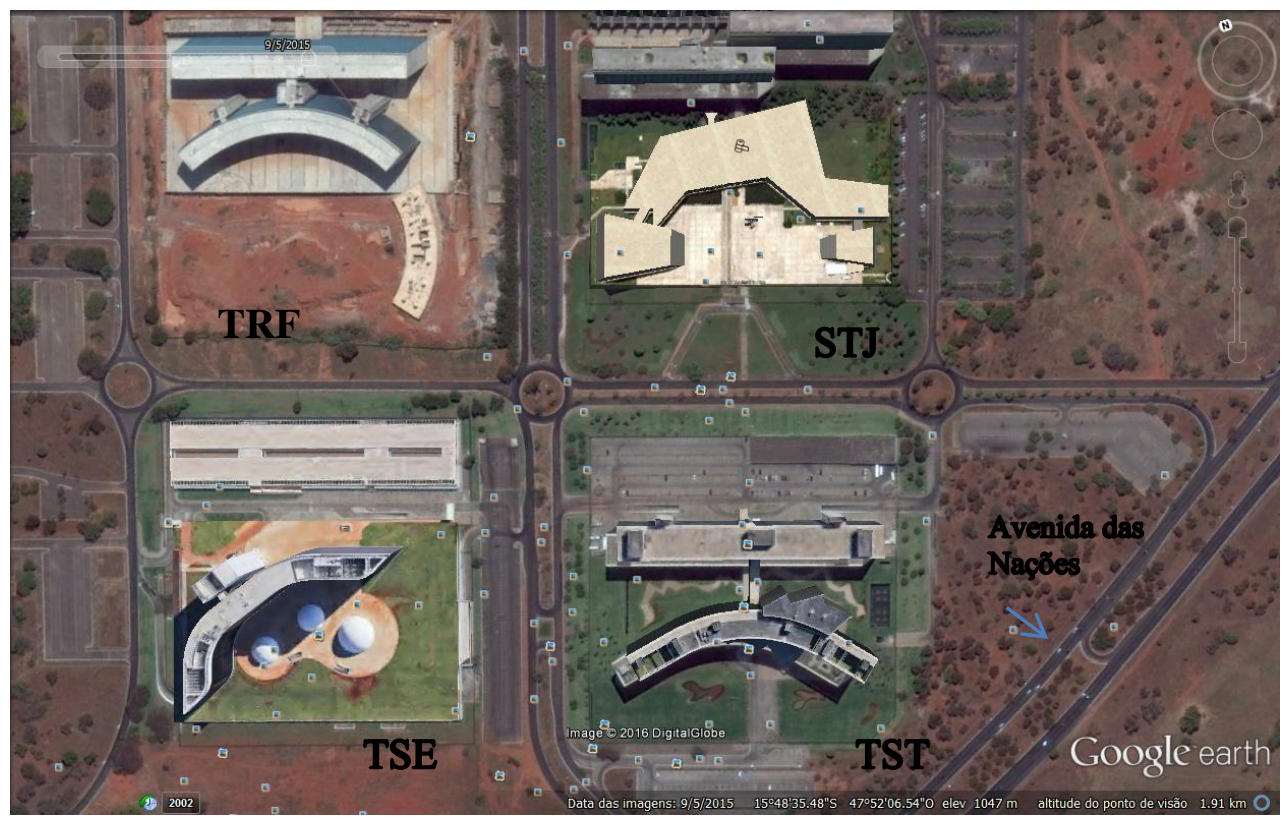

Figura 29: Localização do Tribunal Superior Eleitoral Fonte: Google Earth

A escolha do projeto do TSE como veículo de experimentação levou em consideração sua volumetria, que difere do ângulo reto, que será utilizada para verificar se existe limitação ou simplificação da forma no processo de simulação da luz natural no software Revit. Outro motivo que nos levou a escolher este edifício foi a localização do mesmo, na cidade de Brasília e a possibilidade de acesso à sua documentação para modelagem neste experimento.

A nova sede do Tribunal Superior Eleitoral foi projetada por Oscar Niemeyer, convidado para elaboração do projeto em 2004. O contrato foi assinado em setembro de 2005 e no primeiro semestre de 2006 o projeto foi concluído. A obra foi iniciada em 2007 por meio do consórcio formado pela OAS e Via Engenharia e inaugurada em 15 de dezembro de 2011. O valor aproximado da construção foi de R\$ 327 milhões. (Disponível em: http://www.tse.jus.br/imprensa/noticias-tse/2011/Dezembro/tseinaugura-nova-sede-no-dia-15-de-dezembro acessado em: 15/02/2016.) 
O edifício sede, objeto deste estudo, possui área de 92.172,57 metros quadrados e o edifício anexo área de $19.462,72$ metros quadrados. A área da construção perfaz o total de $111.635,29 \mathrm{~m}^{2}$. A fachada frontal (sul) é toda revestida em vidro e a fachada posterior (norte), também em vidro, conta com brises em toda sua extensão. A volumetria do projeto consiste em uma forma semicircular que acaba em pontas nas extremidades, aonde o vidro da fachada se encontra sendo envolvido por três cúpulas em forma circular que compõem o projeto. As cúpulas são destinadas ao plenário e auditórios e o acesso é feito por meio de uma galeria subterrânea. A fachada norte possui um volume retangular que funciona como circulação vertical e inclui também um estacionamento subterrâneo.

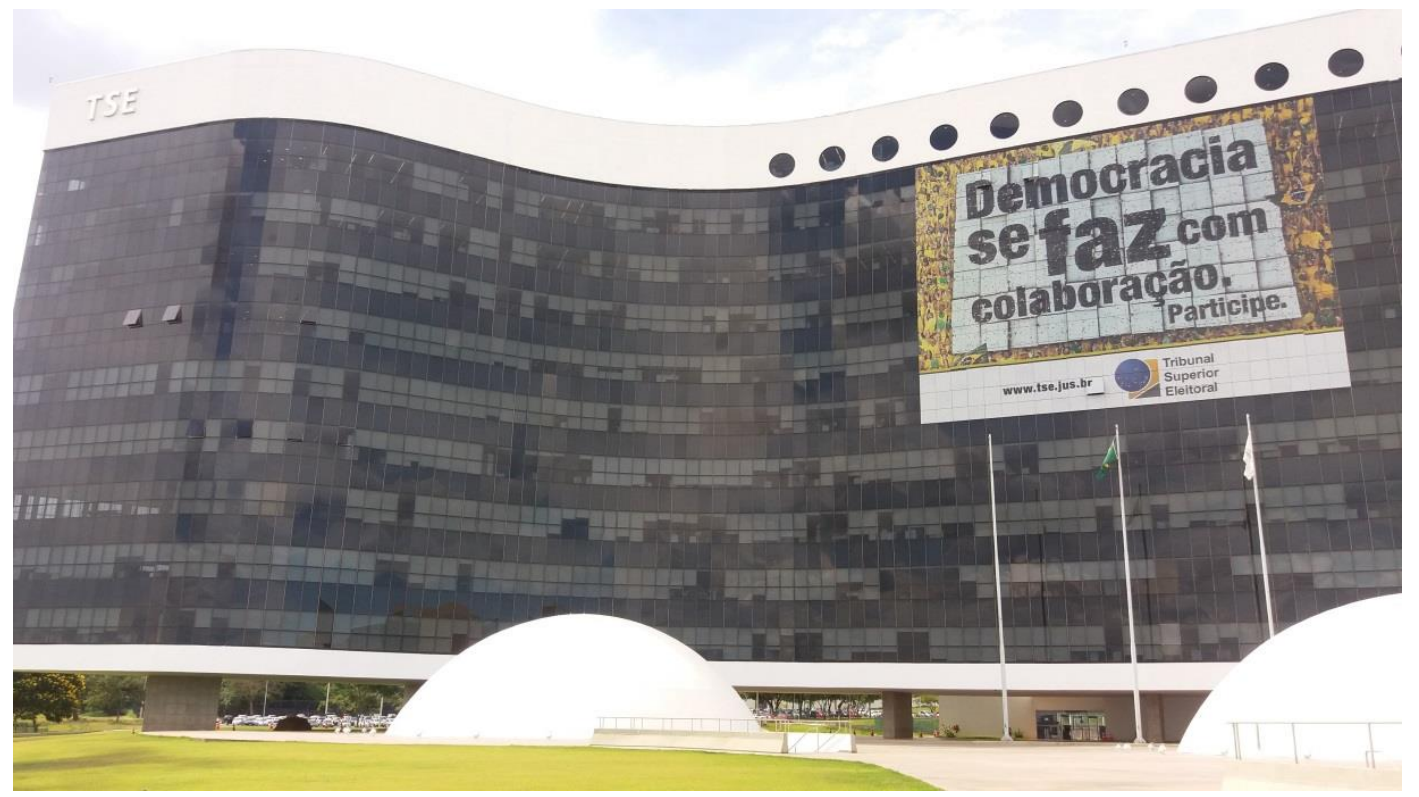

Figura 30: TSE- Fachada Sul/ Edifício Sede Fonte: Acervo pessoal
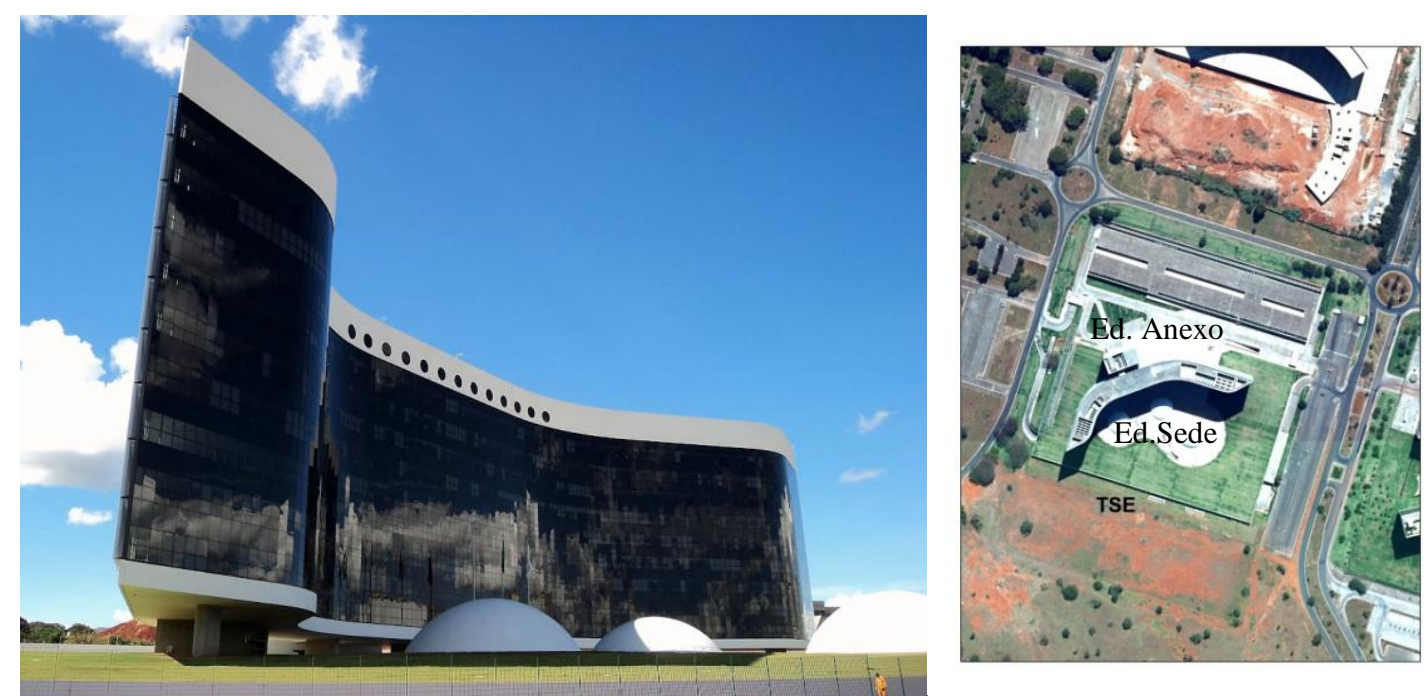

Figura 31: Tribunal Superior Eleitoral/ Localização Fonte: Google Earth e acervo SEGETH 
A forma curvilínea escolhida pelo autor do projeto é um reflexo de sua preferencia, claramente expressa quando afirma que:

\footnotetext{
"Não é o ângulo reto que me atrai; nem a linha reta, dura, inflexível, criada pelo homem. O que me atrai é a curva livre e sensual, a curva que encontro nas montanhas do meu país, no curso sinuoso dos seus rios, nas ondas do mar, no corpo da mulher preferida..." (NIEMEYER apud PEREIRA, 1997, p. 126).
}

O Tribunal Superior Eleitoral (TSE) é o órgão máximo da Justiça Eleitoral e possui ação conjunta com os Tribunais Regionais Eleitorais (TREs). Os TREs são os responsáveis diretos pela administração do processo eleitoral nos Estados e nos municípios. O TSE é composto por sete ministros, dos quais três são originários do Supremo Tribunal Federal-STF, dois do Superior Tribunal de Justiça-STJ e dois representantes da classe dos juristas - advogados com notável saber jurídico e idoneidade. Os ministros representantes STF e STJ são eleitos mediante votação secreta nos respectivos tribunais e os advogados candidatos para compor o TSE são nomeados pela Presidente da República dentre aqueles indicados pelo STF.

Na elaboração e construção do projeto do TSE houve preocupação com o impacto ambiental. Durante a construção, cerca de $90 \%$ dos resíduos gerados entre eles papel, metal e plástico, foram reciclados. Também deve-se observar que a madeira utilizada na construção e acabamento é de reflorestamento. Os elevadores acumulam energia durante o funcionamento para ser reutilizada depois. O sistema de coleta de esgoto é a vácuo para reduzir o consumo de água. Foi projetado um sistema de reutilização da água das torneiras, que é armazenada para uso na irrigação dos jardins e nos serviços gerais de limpeza. O ar condicionado foi projetado para utilizar sistema de redução de gasto energético e utiliza gás para refrigerar que não afeta a camada de ozônio e reduz o consumo de água. (Disponível em: http://www.tse.jus.br/institucional/otse/sede-atual/videos-nova-sede/sustntabilidade. Acessado em: 10 /11/2015.)

Segundo Frederico Vellenich, coordenador de Engenharia e Arquitetura do TSE, a fachada de vidro permite a incidência da luz natural nas áreas de trabalho reduzindo o consumo de iluminação artificial e consequentemente de energia. (Disponível em: http://www.tse.jus.br/institucional/o-tse/sede-atual/videos-nova-sede/sustntabilidade. acesso em: 10/11/2015.)

Vale destacar que conforme vistorias e conversa com a chefe da Seção de Obras e Projetos da Coordenadoria de Engenharia e Arquitetura do TSE, Ana Lucia Lopes 
Zeredo, foi identificado ofuscamento na área de trabalho e para resolver o problema foram instaladas persianas para bloquear a iluminação natural direta. Isto inviabilizou o uso adequado da luz natural, que em muitos casos foi substituída pela artificial.

As persianas localizadas na fachada sul tiveram que ser substituídas por outras visto que as anteriores não estavam resolvendo o problema do excesso de luz natural (ilustrados nas figuras 32). As persianas utilizadas na substituição foi o padrão 802 Eviro da Verosol com fator de abertura igual ou menor que 2\%, reflexão solar superior a $60 \%$, a reflexão luminosa superior a $60 \%$ e a transmissão UV inferior a $6 \%$.
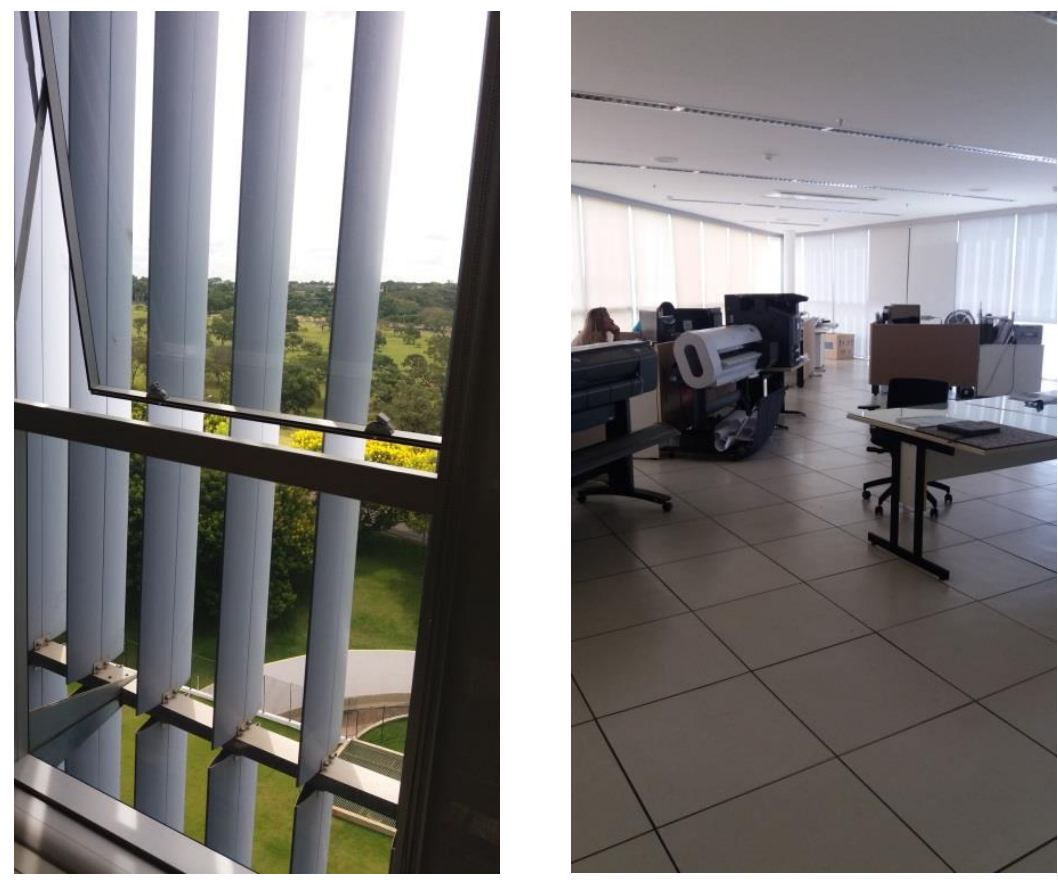

Figura 32: Brises da fachada norte e vista interna -persianas Fonte: acervo pessoal 


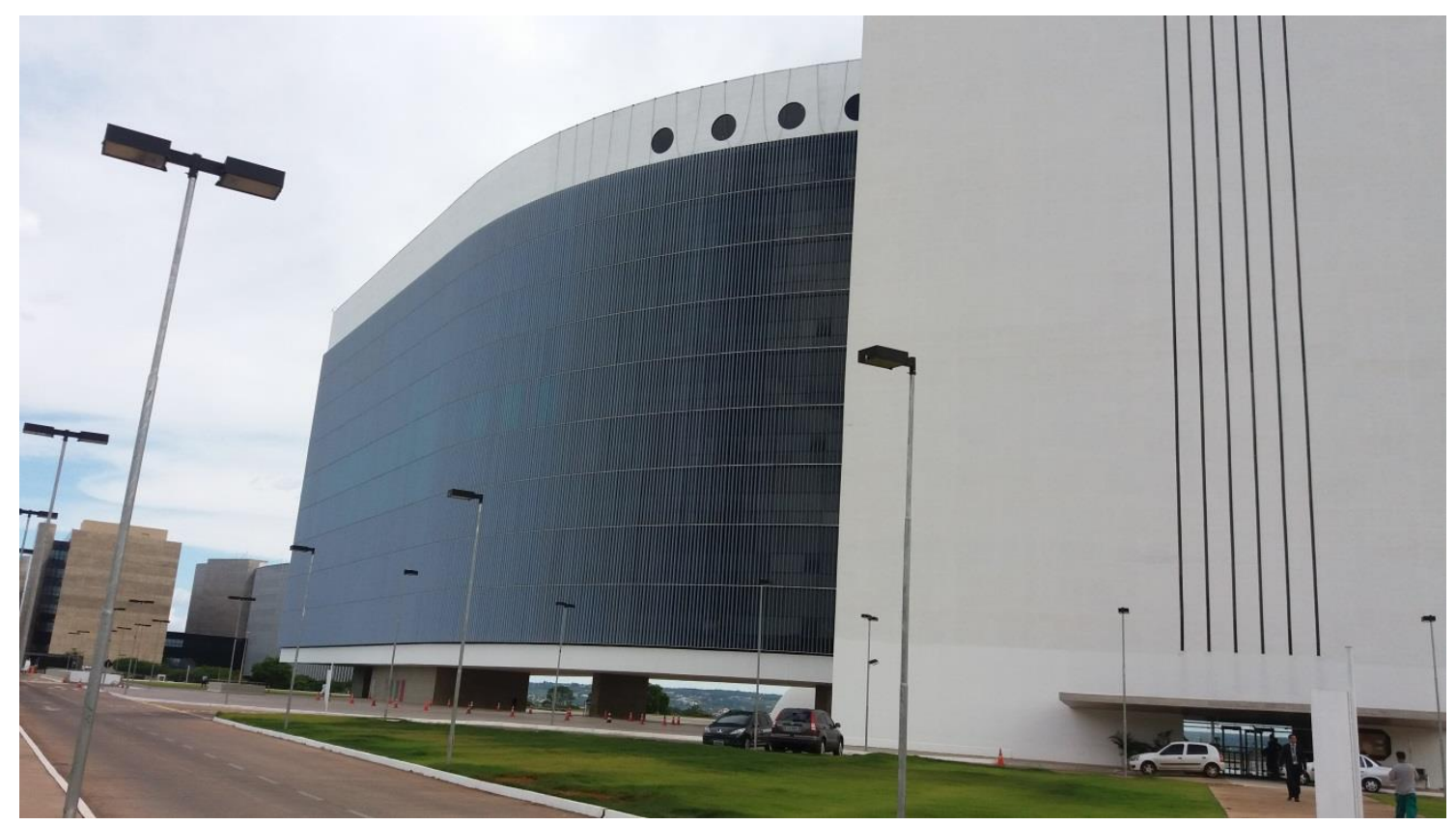

Figura 33: Brises da fachada norte Fonte: acervo pessoal

Conforme informações relatadas pela arquiteta Ana Lucia Zeredo, o sistema de reutilização de água das torneiras para o uso na irrigação dos jardins e nos serviços gerais de limpeza não esta sendo executado por falta de autorização da CAESB.

\subsection{PROCEDIMENTOS METODOLÓGICOS}

A hipótese apresentada no capítulo um desta dissertação consiste na seguinte pressuposição: os sistemas BIM podem contribuir como ferramenta de estudo e avaliação da luz natural no processo de projetação arquitetônica sem a necessidade de exportação do projeto para um simulador ambiental individual.

O recorte deste trabalho se circunscreve a avaliação de qual é o nível de integração atual dos recursos de simulação da LN com o sistema BIM escolhido. Neste experimento será utilizado o software Revit em virtude da integração das funções do simulador ambiental individual denominado Ecotect Analysis ao primeiro. Esta integração e as especificidades dos softwares Revit e Ecotect foram descritos de forma detalhada nos itens 4.5, 5.1 e 5.2 desta dissertação.

O critério para a escolha do sistema BIM utilizado nesta pesquisa, é decorrente do fato de que no Revit a integração de recursos de simulação da LN está mais avançada do que nos demais softwares do sistema BIM. 
Visando a verificação da hipótese e no sentido de alcançar os objetivos propostos nesta Dissertação foi adotada a sequência de procedimento explicitada nos itens 6.2 a 6.7 .

\subsection{LEVANTAMENTO DAS INFORMAÇÕES PARA MODELAGEM NO SISTEMA BIM}

O primeiro procedimento adotado foi o levantamento das informações necessárias do edifício do TSE para modelagem no sistema BIM (REVIT). A documentação do projeto teve como base desenhos elaborados no software AutoCAD como: planta baixa, cortes, fachadas, planta de locação e implantação. Estas informações foram fornecidas pela arquiteta Ana Lúcia Lopes Zeredo, que, conforme mencionado, trabalha como chefe da Seção de Obras e Projetos do TSE.

A figura 34, a seguir, é referente à planta de implantação do projeto onde as edificações estão dispostas da seguinte forma conforme legenda: 1- a volumetria em formato retangular conectada ao edifício sede é a torre de circulação vertical, onde estão localizados o hall dos andares, elevadores, escadas e sanitários coletivos 2- edifício sede, 3- auditório como 288 lugares de usos diversos, 4- auditórios com 120 e 54 lugares de usos diversos e sessões administrativas, 5- auditório 245 lugares e sessões plenárias, 6- edifício anexo da secretaria da informação e 7- guaritas. 


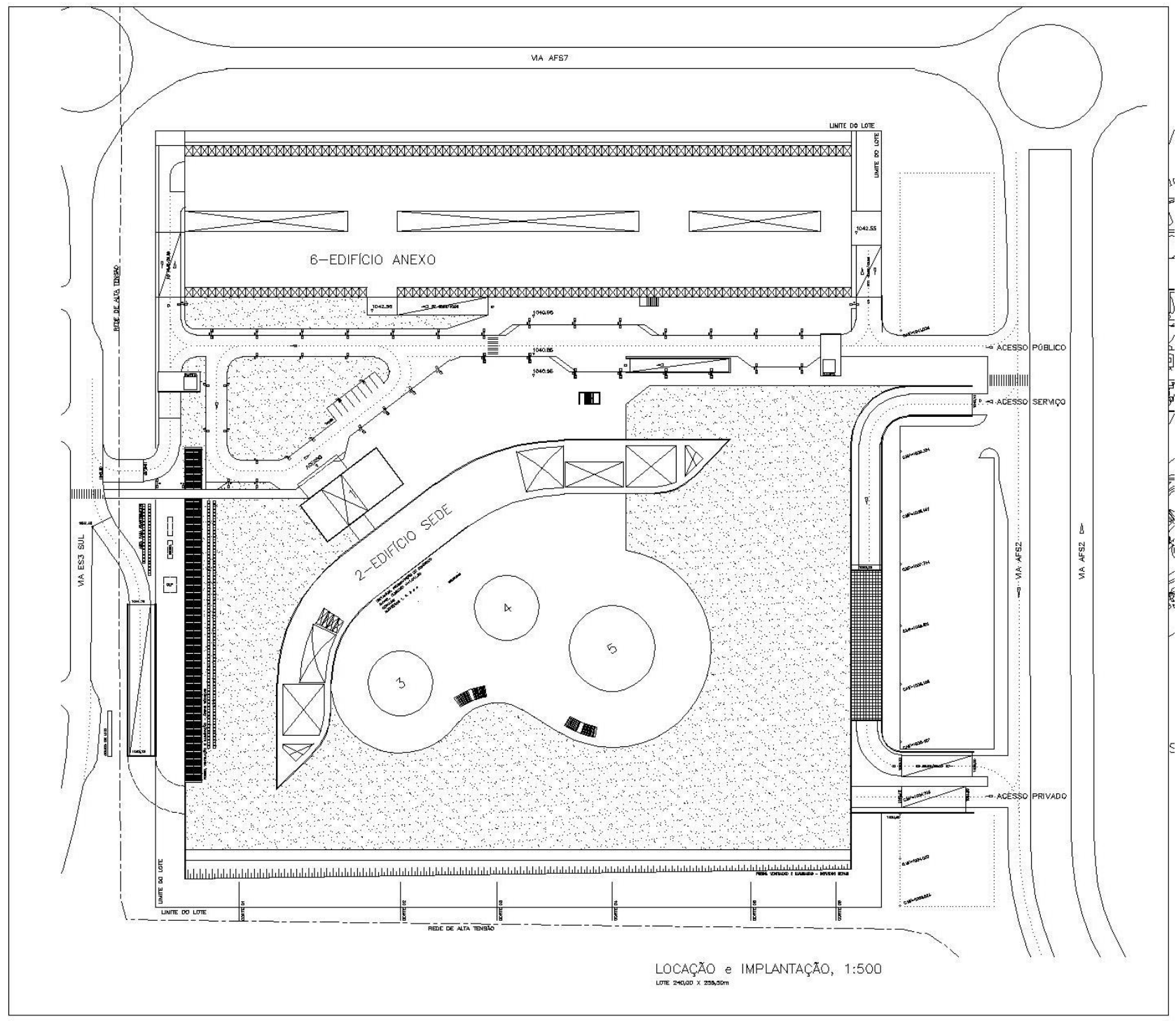

Figura 34: Locação e Implantação

Fonte: Documentação do projeto do TSE fornecida pela chefe da Seção de Obras e Projetos do TSE

O Edifício Sede é composto por pilotis, dez pavimentos e subsolo. Sendo que os nove primeiros pavimentos são destinados a área de expedientes com $31.068,00 \mathrm{~m}^{2}(9 \mathrm{x}$ $3.452,00 \mathrm{~m}^{2}$ ). No décimo pavimento encontra-se o restaurante, casas de máquinas, elevadores e climatização.

A planta baixa do pavimento térreo (ilustrada na figura 35), onde estão localizados os pilotis em concreto aparente, foi dividida em três partes. Neste pavimento localizam-se a torre de circulação vertical que é o acesso principal do público, hall de acesso dos ministros nas duas pontas, máquinas de pressurização, quadro elétrico, telefone público, protocolo e shafts. 


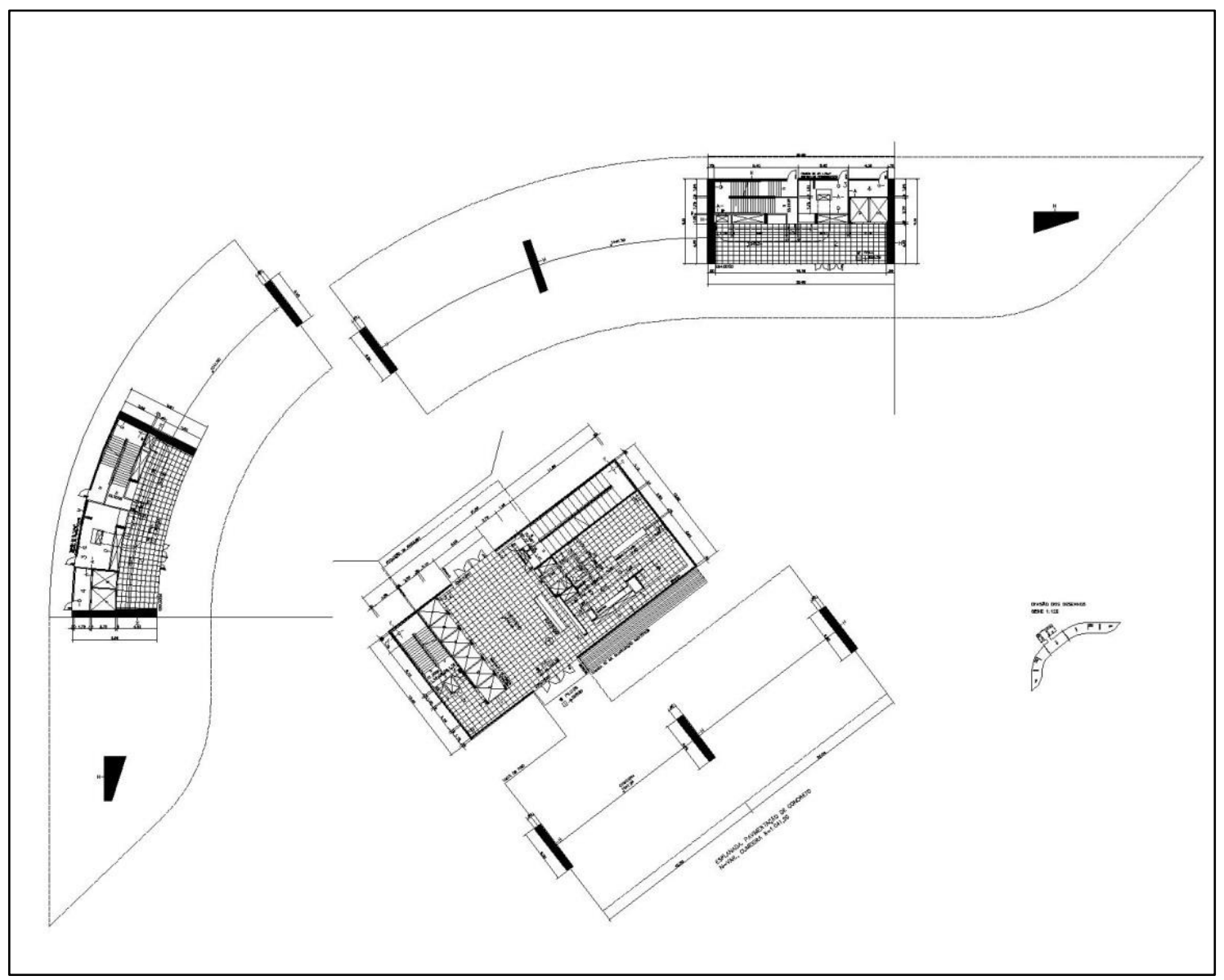

Figura 35: Planta Baixa Térreo -Edifício Sede Fonte: Documentação de projeto TSE

A figura 36 representa a planta baixa do primeiro pavimento onde estão localizadas salas de trabalho, sanitários, circulação, biblioteca, sala de ar condicionado e shafts. Foi utilizado piso de granito preto na circulação, escadas, copas e sanitários. O teto é em gesso cartonado, com pintura PVA branca. Possui ar condicionado central para todas as salas de trabalho e auditórios e ventilação mecânica com insuflação e exaustão para áreas da garagem. 


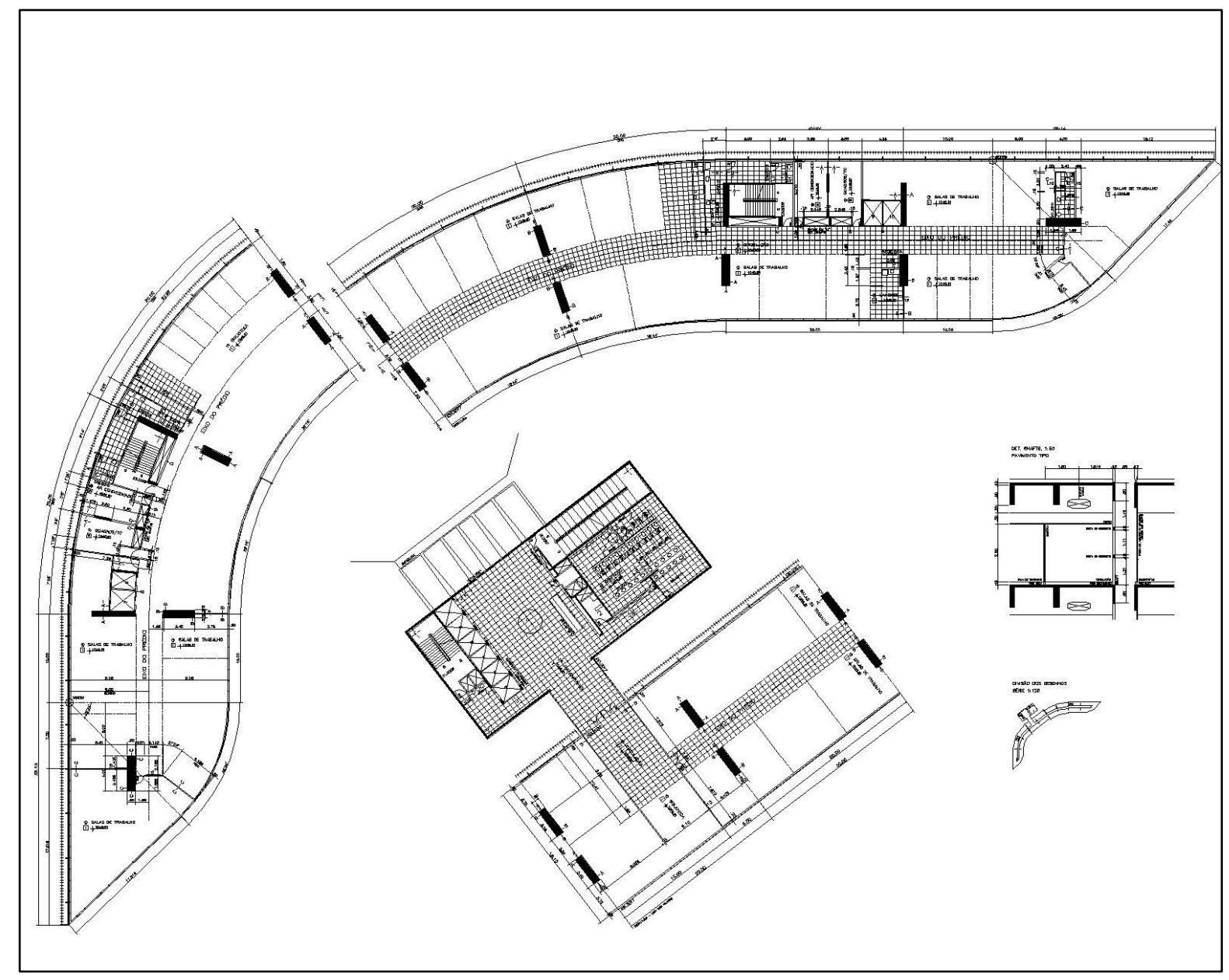

Figura 36: Planta Baixa Primeiro Pavimento -Edifício Sede Fonte: Documentação de projeto TSE

Os pavimentos dois a nove possuem plantas similares, conforme ilustrado na figura 37. Existem algumas divergências de layout nestes pavimentos devido a configurações internas de divisórias das salas conforme necessidade de cada setor do tribunal. A volumetria do projeto é a mesma para todos os pavimentos e não existe um estudo bioclimático para adequação de cada pavimento. O brise soleil da fachada norte é vertical e fixo e não pode ser ajustado conforme o período do dia e época do ano. 


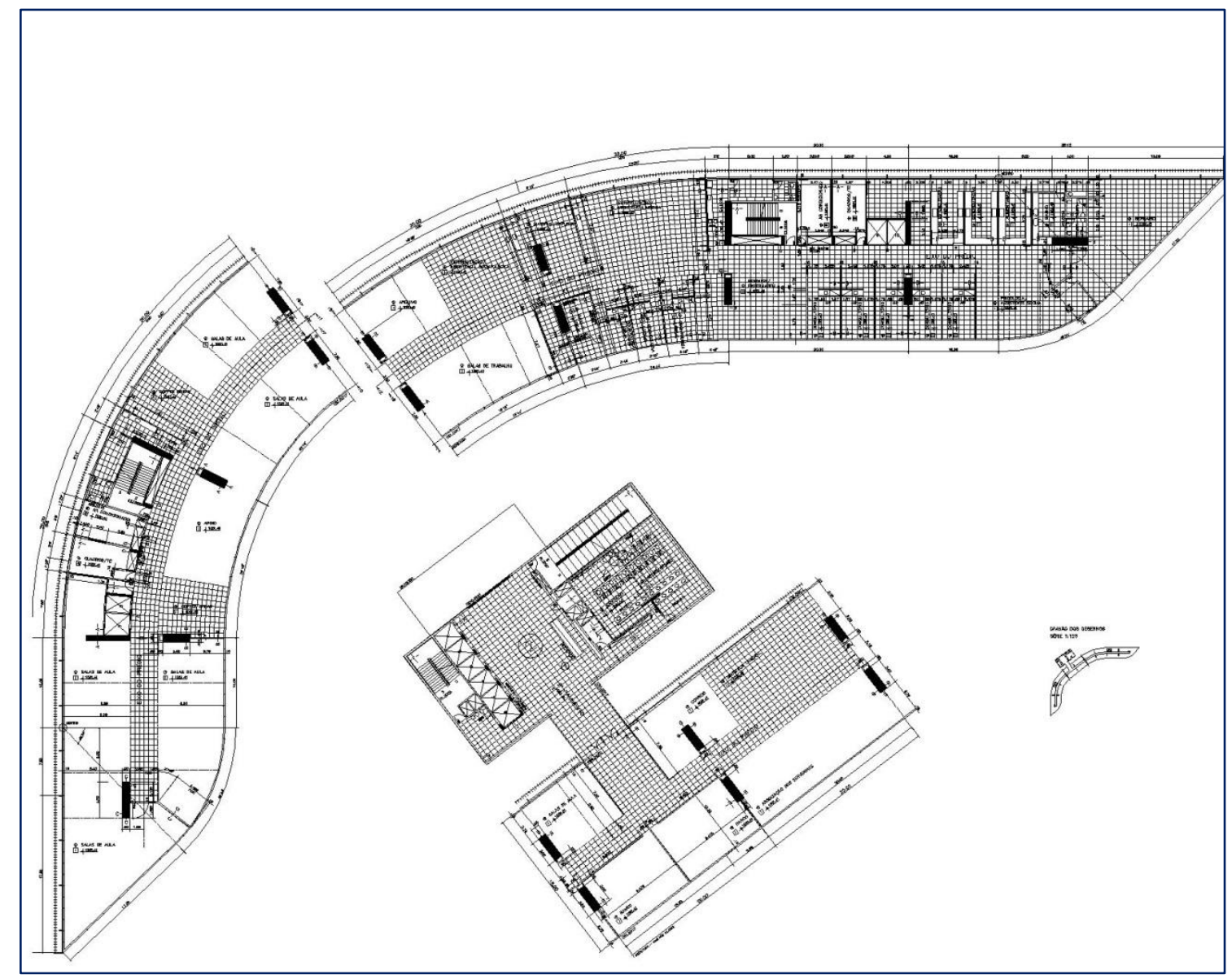

Figura 37: Planta Baixa Pavimento tipo -Edifício Sede Fonte: Documentação de projeto TSE

O décimo pavimento (figura 38) onde está localizado o restaurante é o que mais difere em termos de layout. Este pavimento possui uma cozinha industrial com câmaras frigoríficas, local para armazenagem do lixo, sala de lavagem de panelas, sala de lavagem de pratos, sala para nutricionista, rouparia, boxes de preparo dos alimentos, despensa, refeitório, jardim, depósito e sala de máquina dos elevadores e ar condicionado. 


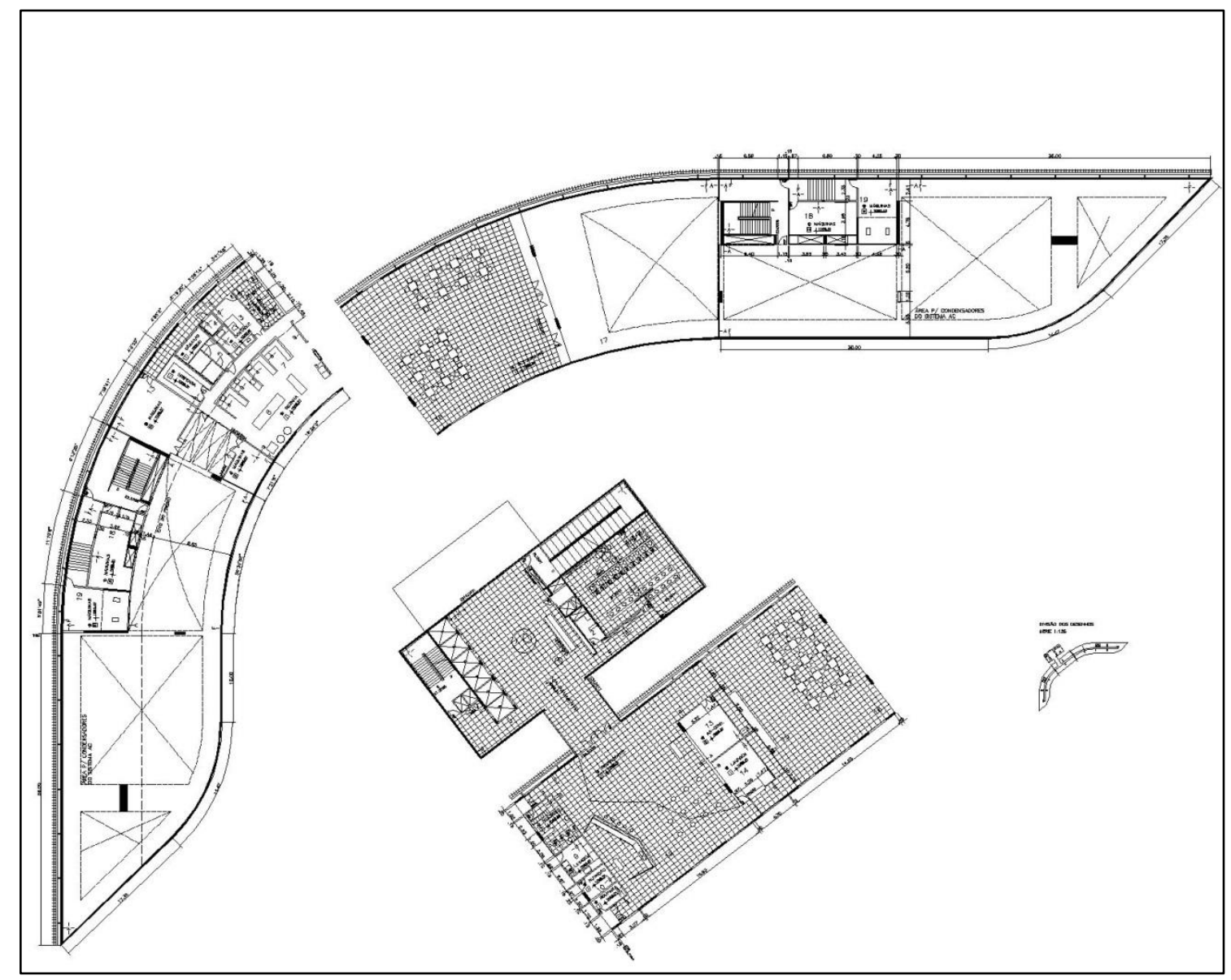

Figura 38: Planta Baixa 10 Pavimento -Edifício Sede

Fonte: Documentação de projeto TSE

\subsection{LEVANTAMENTO DE INFORMAÇÕES REFERENTES ÀS ESPECIFICAÇÕES DOS MATERIAIS}

As informações referentes às especificações de materiais, foram obtidas por meio de caderno de especificações de instalações básicas da obra, desenhos técnicos adquiridos na etapa 1, visita no local para levantamento de dados e informações fornecidas pela arquiteta Ana Lúcia Lopes Zeredo.

Os acabamentos gerais do edifício sede são: estrutura em concreto aparente, pintura acrílica branca sobre concreto, pilares cilíndricos em formas metálicas, esquadrias panorâmicas Structural Glazing nas duas fachadas com janelas maximum-ar, caixilharia em alumínio, vidros laminados $8 \mathrm{~mm}(4 \mathrm{~mm}+4 \mathrm{~mm})$ lisos e transparentes cor cinza com filme incolor e colagem com silicone estrutural Dow Corning 995, fachada norte com brise soleil vertical da Hunter Douglas - Itatiaia. 


\subsection{ELABORAÇÃO DO MODELO GEOMÉTRICO TRIDIMENSIONAL DO EDIFÍCIO DO TSE NO SISTEMA BIM}

Visto que a planta baixa do projeto encontra-se dividida em três partes, conforme visualizado nas figuras de 34 a 38, foi necessário antes da exportação do arquivo para o Revit, unir estas partes no software Autocad formando a volumetria do projeto e foi retirada as informações desnecessárias para modelagem.

No Revit por meio do comando "Insert / Import CAD" foram inseridas a Planta Baixa do Térreo, Primeiro Pavimento, Segundo Pavimento, Décimo Pavimento e Implantação. Nesta etapa também foram realizados o estudos da volumetria e alturas dos pavimentos do projeto através das plantas de cortes e vistas adquiridas na etapa de levantamento de dados. Para inserir a altura dos pavimentos foi utilizado o comando “Architecture / Level” com a vista de elevação selecionada ("Project Browser/ Elevations").

Os níveis ("level”) são planos horizontais infinitos que funcionam com referência para inserção de elementos como piso, paredes, lajes, portas entre outros. Os níveis normalmente são utilizados para definir altura vertical dos pavimentos da construção.

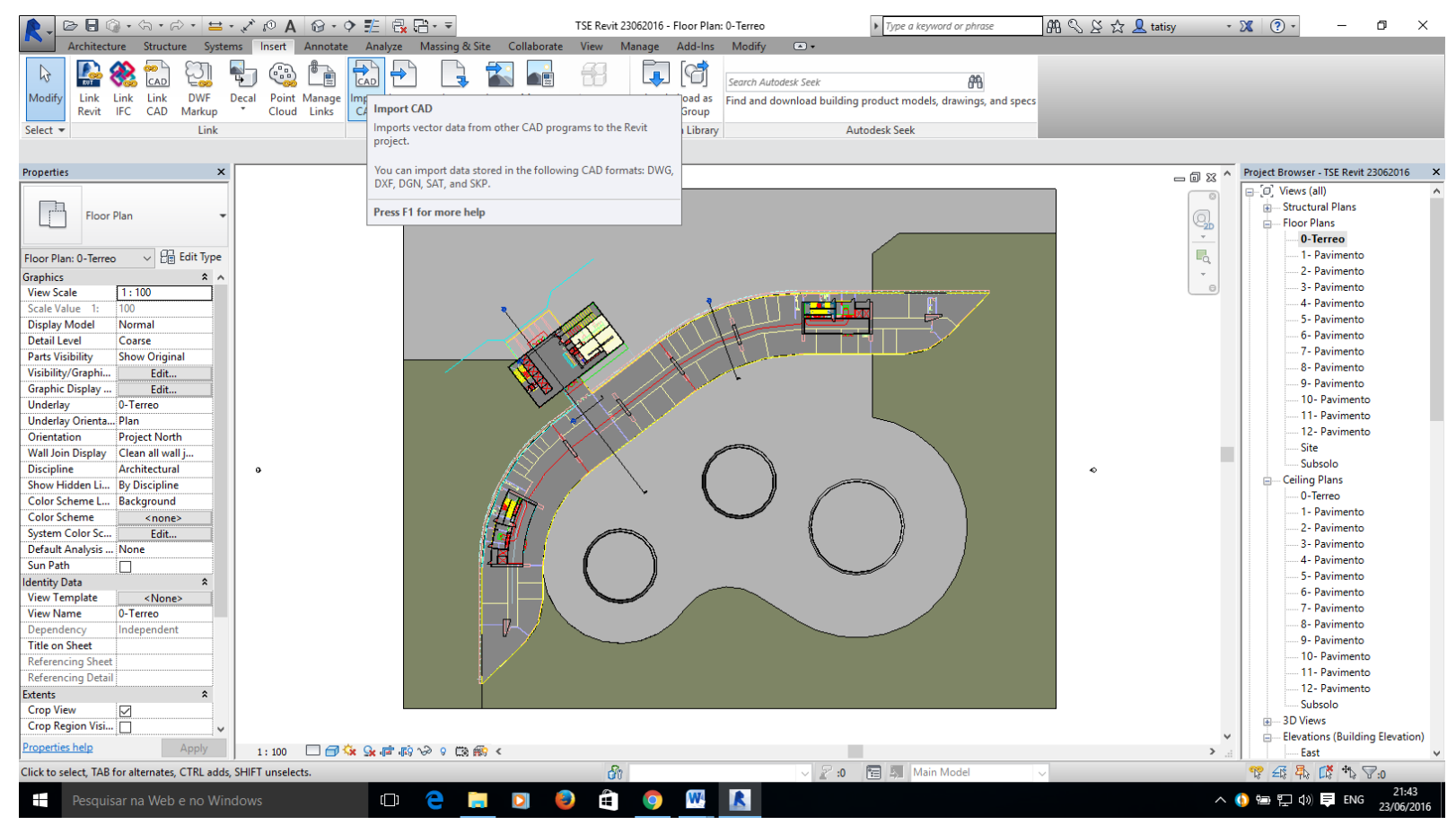

Figura 39: Planta Baixa do Térreo inserida no Revit. Fonte: autoria nossa 


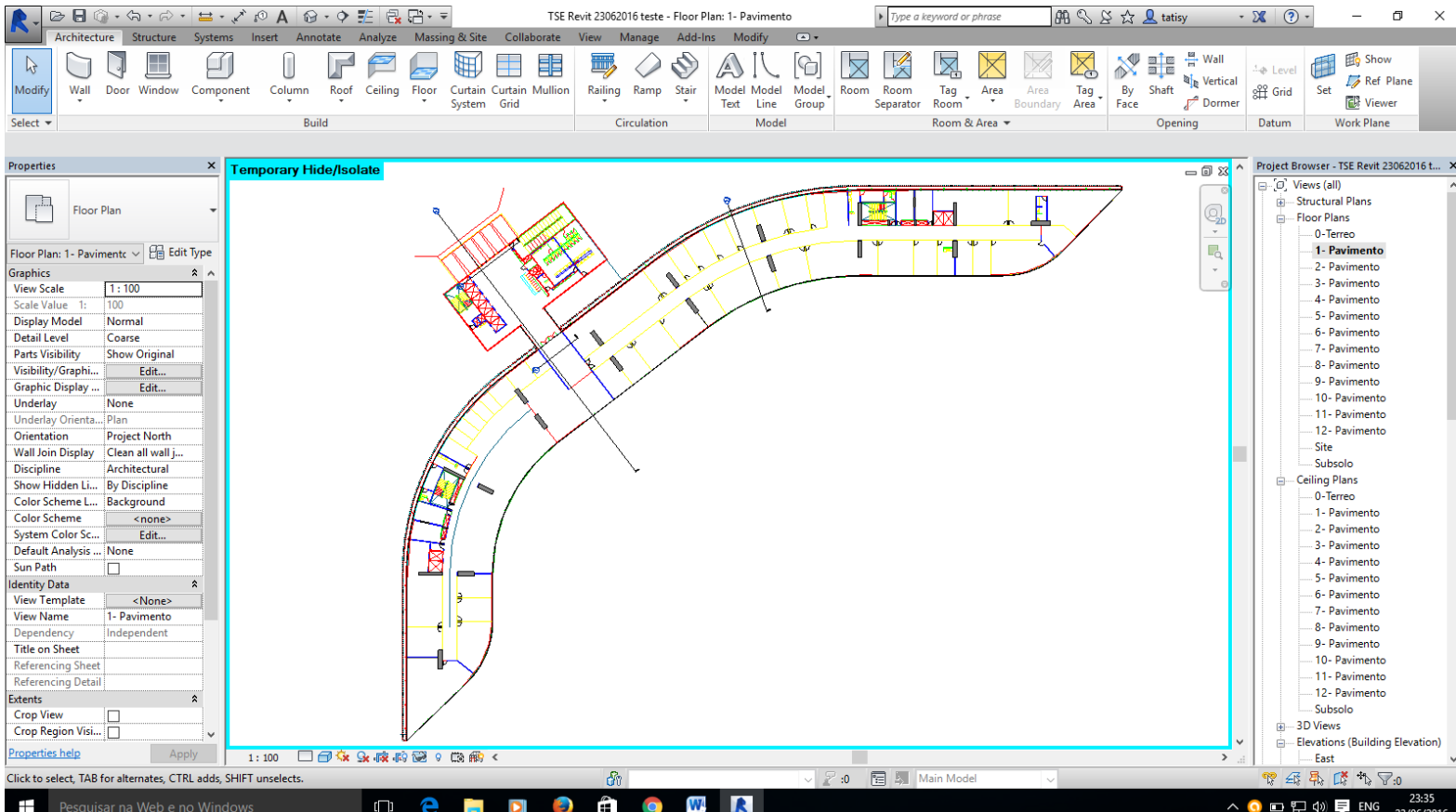

Figura 40: Planta Baixa do Primeiro Pavimento inserida no Revit. Fonte: autoria nossa

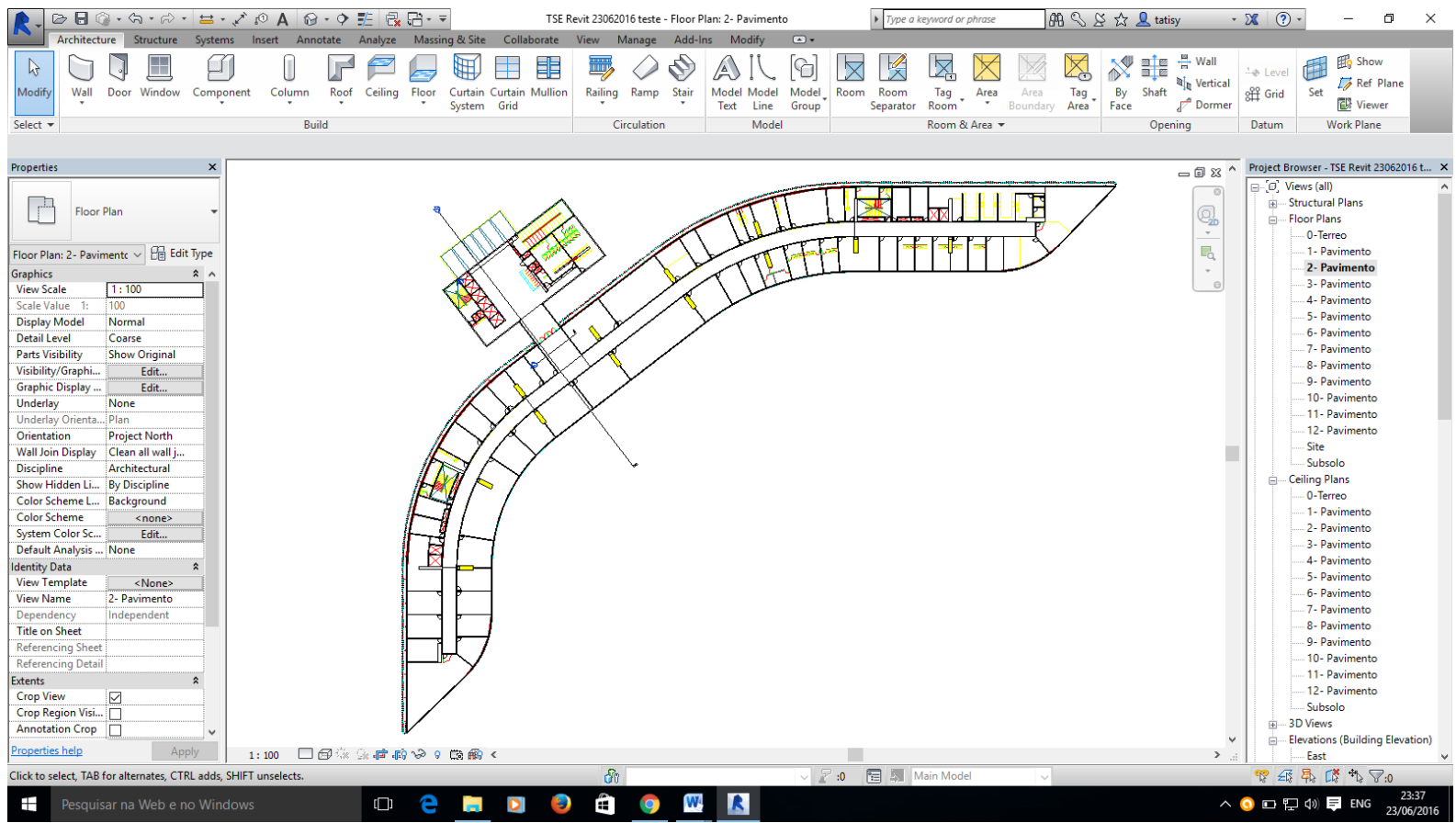

Figura 41: Planta Baixa do Segundo Pavimento inserida no Revit. Fonte: autoria nossa 


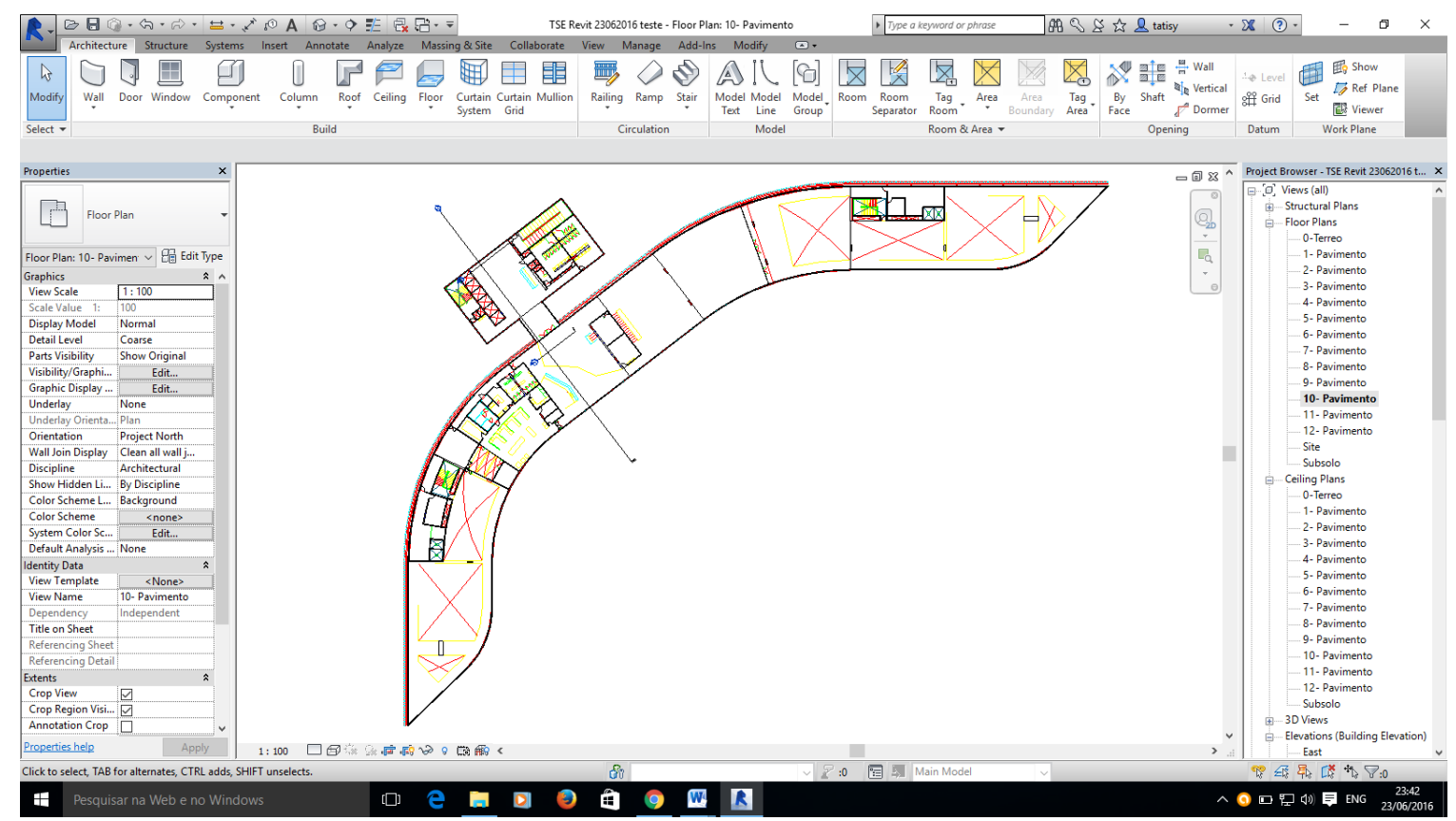

Figura 42: Planta Baixa do Décimo Pavimento inserida no Revit. Fonte: autoria nossa

Posteriormente foi iniciada a fase de modelagem do edifício do TSE no Revit. Para viabilizar esta construção foram utilizadas as famílias de elementos do Revit como paredes, lajes, pisos, pilares, portas, janelas e modeladas conforme especificações do projeto do TSE. As famílias são grupos de elementos com características semelhantes que se encontram pré-definidas no software e podem ser alteradas para atender requisitos do projeto. É possível também criação de novas famílias no Revit.

A construção do modelo foi executada em etapas: primeiro foi modelado o pavimento Térreo, depois o Primeiro Pavimento, o Segundo Pavimento e o Décimo Pavimento. Vale lembrar que do segundo ao nono pavimentos as configurações internas são similares, portanto o segundo pavimento foi copiado através do comando "copy to clipboard" > "aligned to selected leves" e selecionado do terceiro ao nono pavimentos.

Para modelagem do edifício do TSE no Revit foram utilizados os comandos listados abaixo:

“Architecture/ Floor" para a construção dos pisos com diferentes espessuras e revestimento;

"Foundation" para construção de Lajes;

"Structure/ Column" para construção dos pilares, alguns pilares do projeto tiveram que ser construídos através de criação de novas famílias visto que seu formato difere do retangular e quadrado que é o padrão do software; 
"Architecture/ Wall” para construção das paredes com diferentes espessuras e especificações dos materiais;

“Architecture/ Curtain Wall” para construção das paredes cortinas em vidro da fachada do projeto e parede de vidro dos ambientes internos;

"Architecture/ Curtain Grid" para construção das linhas auxiliares verticais e horizontais para inserir os montantes nas paredes de vidro;

"Architecture/ Mulion" para inserir montantes;

"Architecture/ Door" para inserir portas nas paredes, algumas famílias de portas tiveram que ser modificadas através do comando "Edit Family" para adequação das especificações do projeto.

“Architecture/ Window" para inserir as janelas nas paredes, antes de inserir as janelas foi necessário criar uma nova família de janela através dos comandos "new"> "family"> "metric window" para construção das janelas redondas localizadas no décimo pavimento;

"Architecture/ Ceiling" para inserir o forro de gesso nos pavimentos.

Todas as famílias de objetos possuem a guia de propriedades ("properties") para definição das especificidades de cada elemento da construção como espessura, especificações dos materiais, altura. O software permite personalizar as características dos elementos de acordo com as necessidades do projeto.

Verificou-se que na modelagem da fachada curva de vidro do TSE houve simplificações da forma. As fachadas de vidro foram construídas por meio do comando "Curtain Wall” (que é a família do Revit para projetar paredes de vidro). Em seguida foi selecionado na barra de "modify" a opção "pick lines", na qual utilizou-se a planta baixa de documentação do projeto inserida no Revit para construir a volumetrias da fachada. Contudo para definir a curva foi necessário definir uma largura do gride vertical ("vertical grid") no guia de propriedade do Revit. Caso não tivessem sido definidos a largura do gride vertical o software não entenderia a parede como curva, sendo projetada uma linha diagonal reta unindo as duas pontas da curva. A fachada curva foi facetada em linha retas de 1,25 metros que é espessura dos painéis e montantes do TSE.

Vale informar que a fachada curva pode também ser modelada selecionando o comando para parede (“Architecture / Wall”) onde não foi verificada simplificação da forma mas é necessário especificar o material utilizado e espessura do vidro na guia de 
propriedades. No guia de propriedades do comando parede não foi possível inserir os painéis e montantes do vidro.

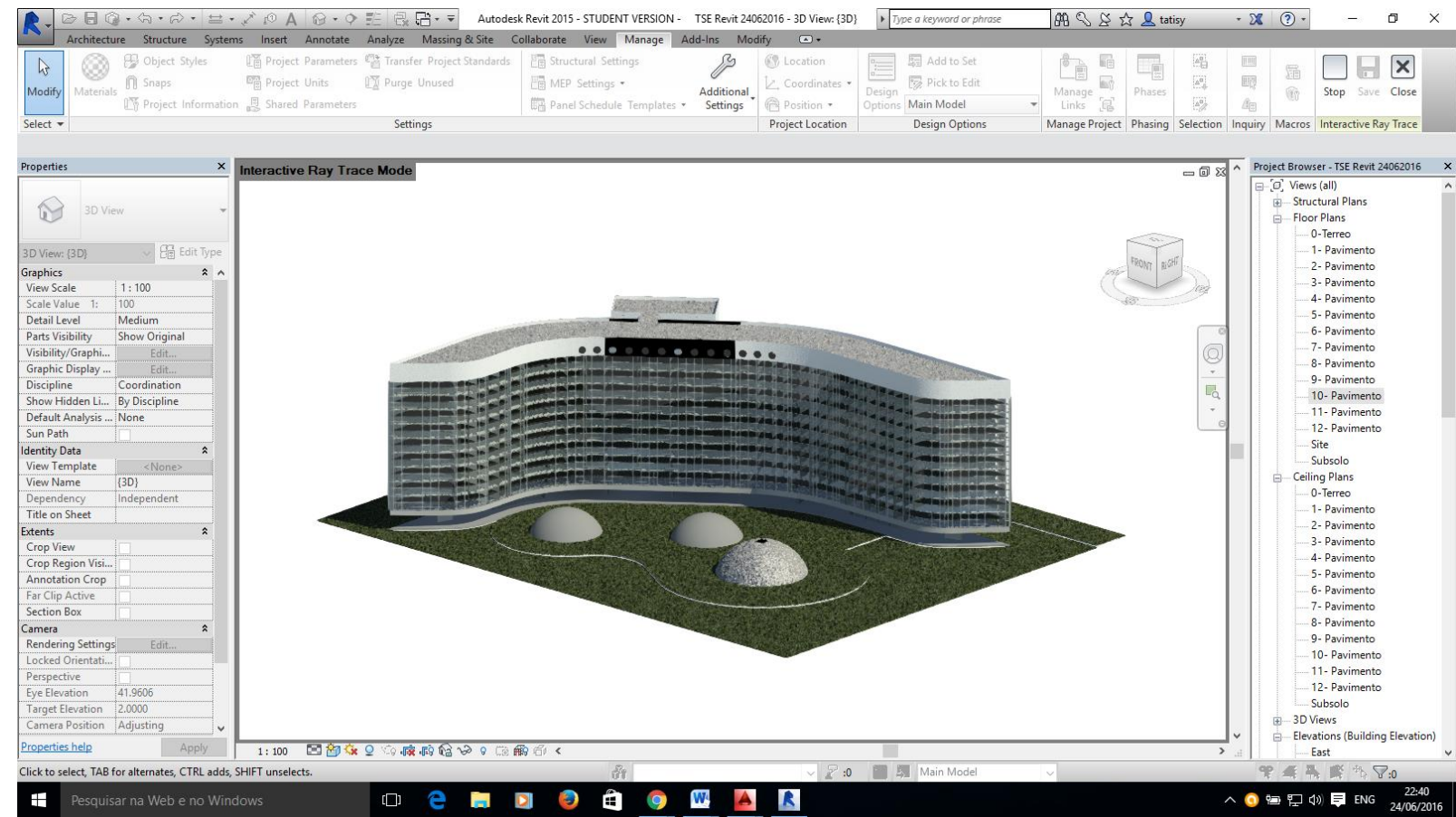

Figura 43: Modelo geométrico tridimensional do edifício do TSE/ Fachada Sul Fonte: autoria nossa

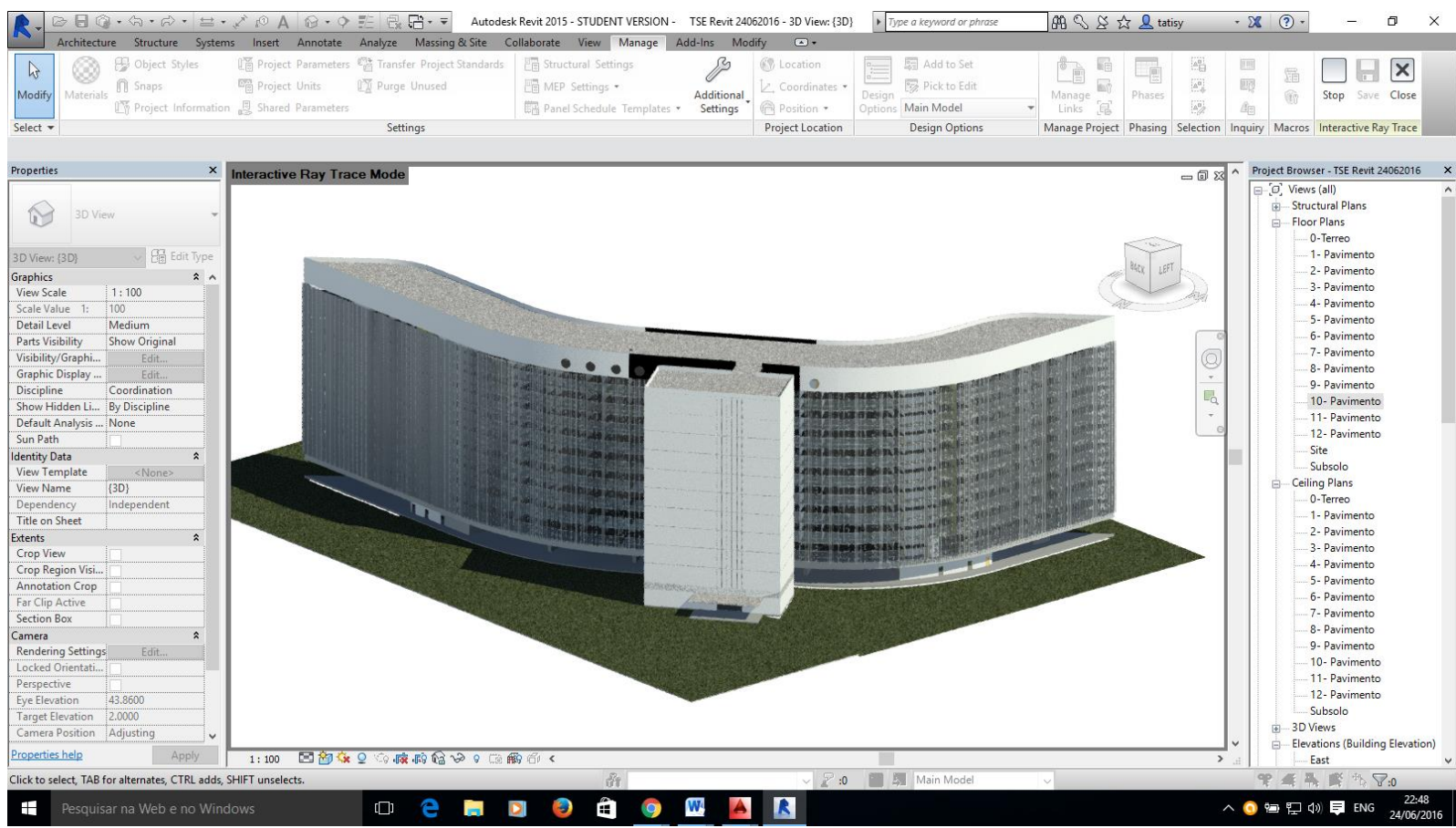

Figura 44: Modelo geométrico tridimensional do edifício do TSE/ Fachada Norte Fonte: autoria nossa 

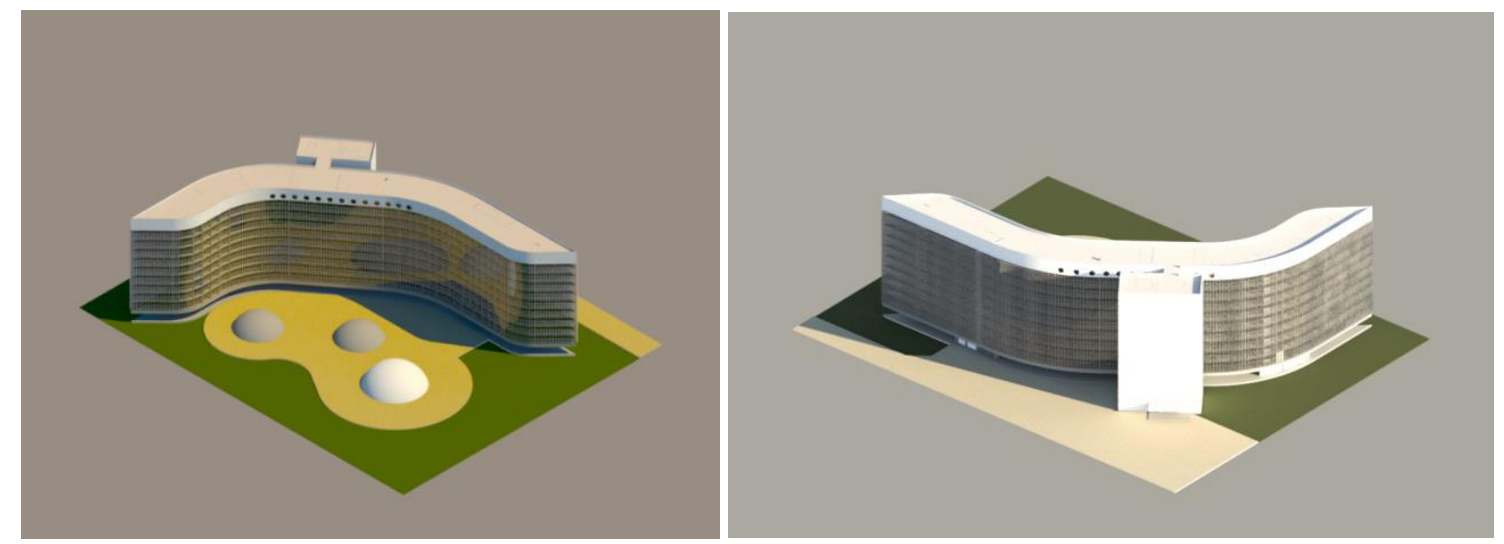

Figura 45: Imagem Renderizada do edifício do TSE/ Fachadas sul e norte Fonte: autoria nossa

A modelagem nos sistemas BIM difere em vários quesitos em relação aos sistemas CAD - não BIM. Entre essas diferenças podemos citar o fato de que nos sistemas BIM modela-se não apenas a visualização do projeto, mas, também, os componentes da construção com suas propriedades, quantificações e especificações de materiais que estão associados por meio de regras paramétricas que descrevem como se comportam conforme a realidade. Já os sistemas CAD - não BIM trabalham com linhas, vetores e formas que representam estes componentes da construção. Outra questão importante nos sistemas BIM é que os elementos do edifício possuem uma base de dados vinculada coordenada com uma relação direta entre as várias componentes da construção em modelo mestre que pode ser inserido todas as informações para a construção projeto.

No início a modelagem nos sistemas BIM demanda não apenas o aprendizado de novos comandos e uso de um software, mas exige, também, uma nova forma de pensar o projeto em que o modelo digital representa o objeto real e não apenas representações geométricas. Neste contexto, é necessário que o projetista tenha conhecimento de sistemas construtivos onde o modelo mestre concentra todas as informações necessárias entre as diferentes disciplinas (hidráulica, elétrica, sistemas estruturais) para construção do edifício. Os membros das equipes devem trabalhar de forma colaborativa com uma maior integração entre os diferentes agentes envolvidos no processo de elaboração e construção do projeto.

Ao elaborar o modelo tridimensional paramétrico do projeto nos sistemas BIM, as plantas de documentação (planta baixa, cortes, fachadas...) são geradas automaticamente. E modificações do modelo mestre como, por exemplo, alteração da altura da laje viabilizam ajustes automáticos nas alturas das paredes e atualizações no 
banco de dados da documentação do projeto de forma coordenada evitando possíveis erros e retrabalhos.

\subsection{REALIZAÇÃO DA SIMULAÇÃO DA LUZ NATURAL NO SISTEMA BIM}

Nesta etapa do experimento foram desenvolvidas simulações ambientais da luz natural no próprio sistema BIM (Revit) com o objetivo de evitar a necessidade de refazer o projeto ao exportar o modelo para um simulador ambiental individual. Do item 6.5.1 ao 6.5.8 foram descritas as operações executadas no Revit para realizar a análise da LN e verificou-se a necessidade da instalação de um plug-in no software para algumas simulações. Também foi verificada a procedência das informações relatadas pela Autodesk, descritas no item 5.2 desta Dissertação.

\subsubsection{LOCALIZAÇÃO GEOGRÁFICA DO PROJETO}

A localização geográfica do projeto no Revit pode ser definida através do endereço do projeto, cidade mais próxima ou latitude e longitude. Esta configuração é útil para a geração de localização específica de sombras nas vistas do projeto e estudos solares. A localização fornece a base para a informação do clima.

Os procedimentos adotados para localização geográfica do TSE no Revit foram:

- Selecionar os comandos "Manage"> "Location"> Internet Mapping Service.

O serviço de mapeamento pela internet só pode ser executado quando o computador estiver conectado a internet. Ao selecioná-lo é exibido um mapa interativo que funciona por meio do "Google Maps". Desta forma, são definidas a longitude e latitude da localização do projeto.

A localização do projeto pode ser definida também conforme a lista de cidades padrão, sem necessidade de conexão com a internet. 


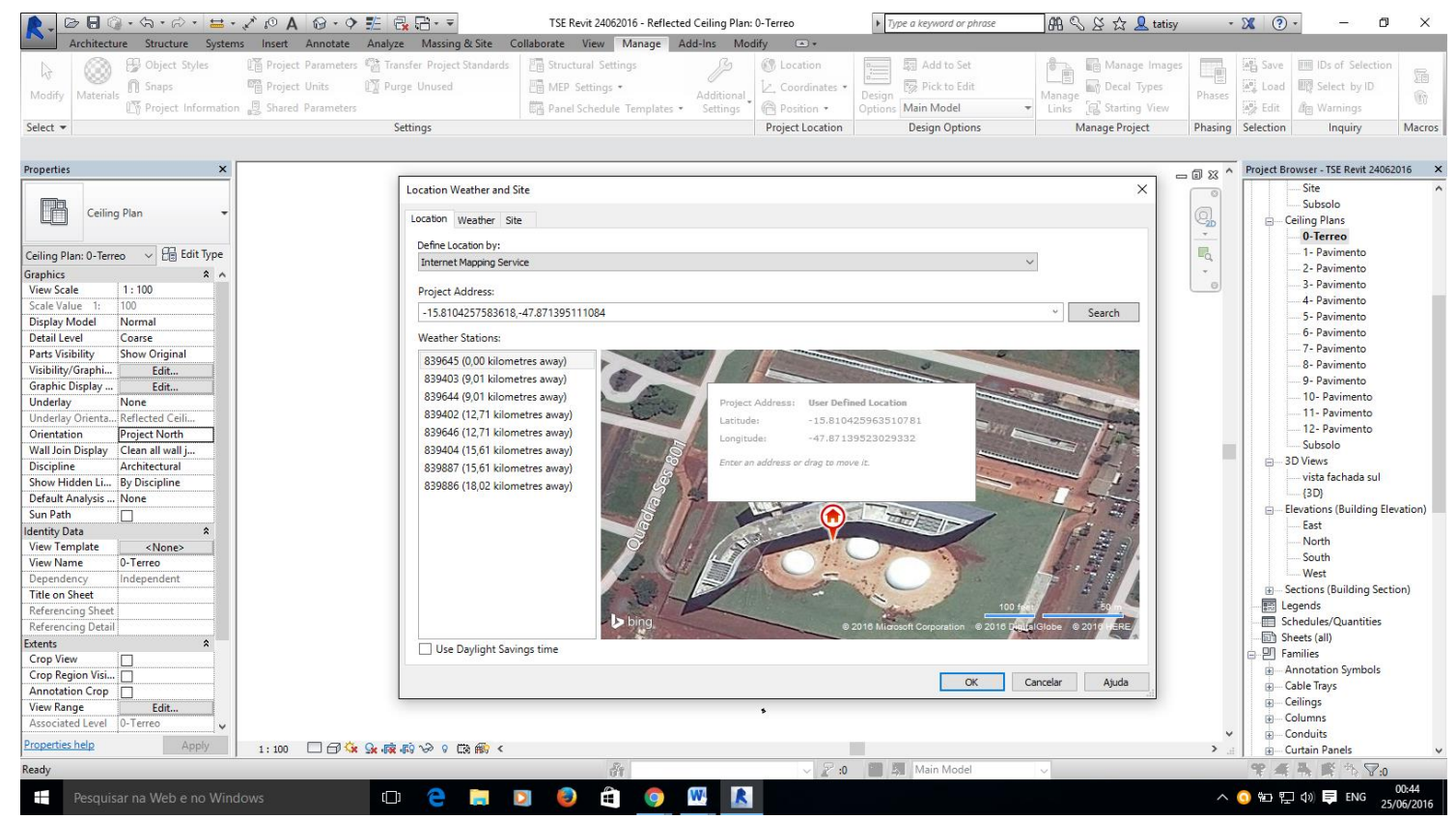

Figura 46: Localização geográfica do projeto no Revit Fonte: autoria nossa

\subsubsection{CONFIGURAÇÃO DO NORTE VERDADEIRO NO REVIT}

Os projetos no Revit possuem dois tipos de norte, o norte verdadeiro ("true north") e o norte de projeto ("project north"). O norte de projeto encontra-se a 90 graus e o norte verdadeiro do TSE encontra-se a 107 graus. O posicionamento do norte verdadeiro requer executar os seguintes comandos:

"Manage"> "Position"> "Rotate True North" e selecionar o ângulo de rotação em relação ao norte de projeto.

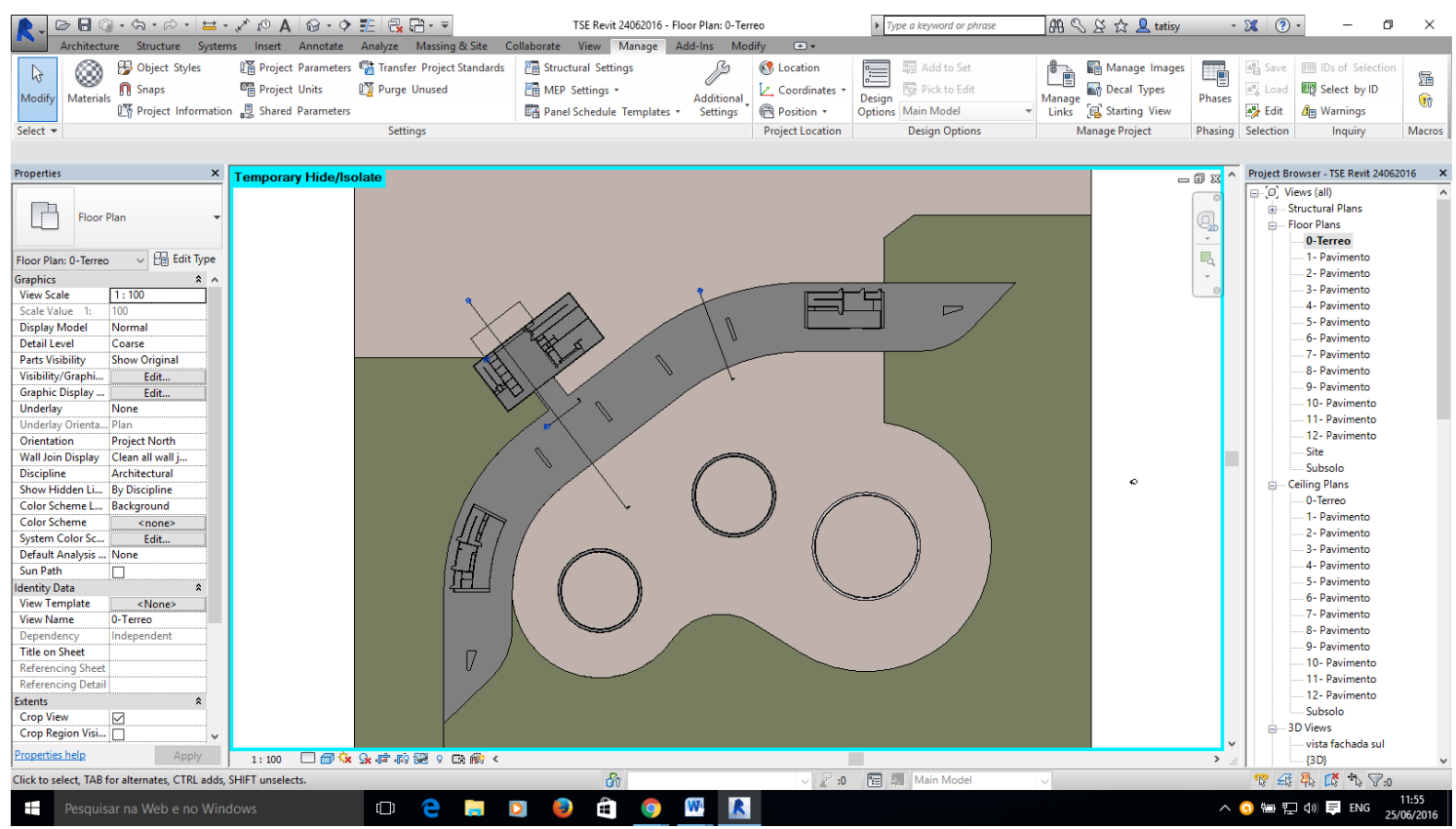

Figura 47: Norte de Projeto Fonte: autoria nossa 


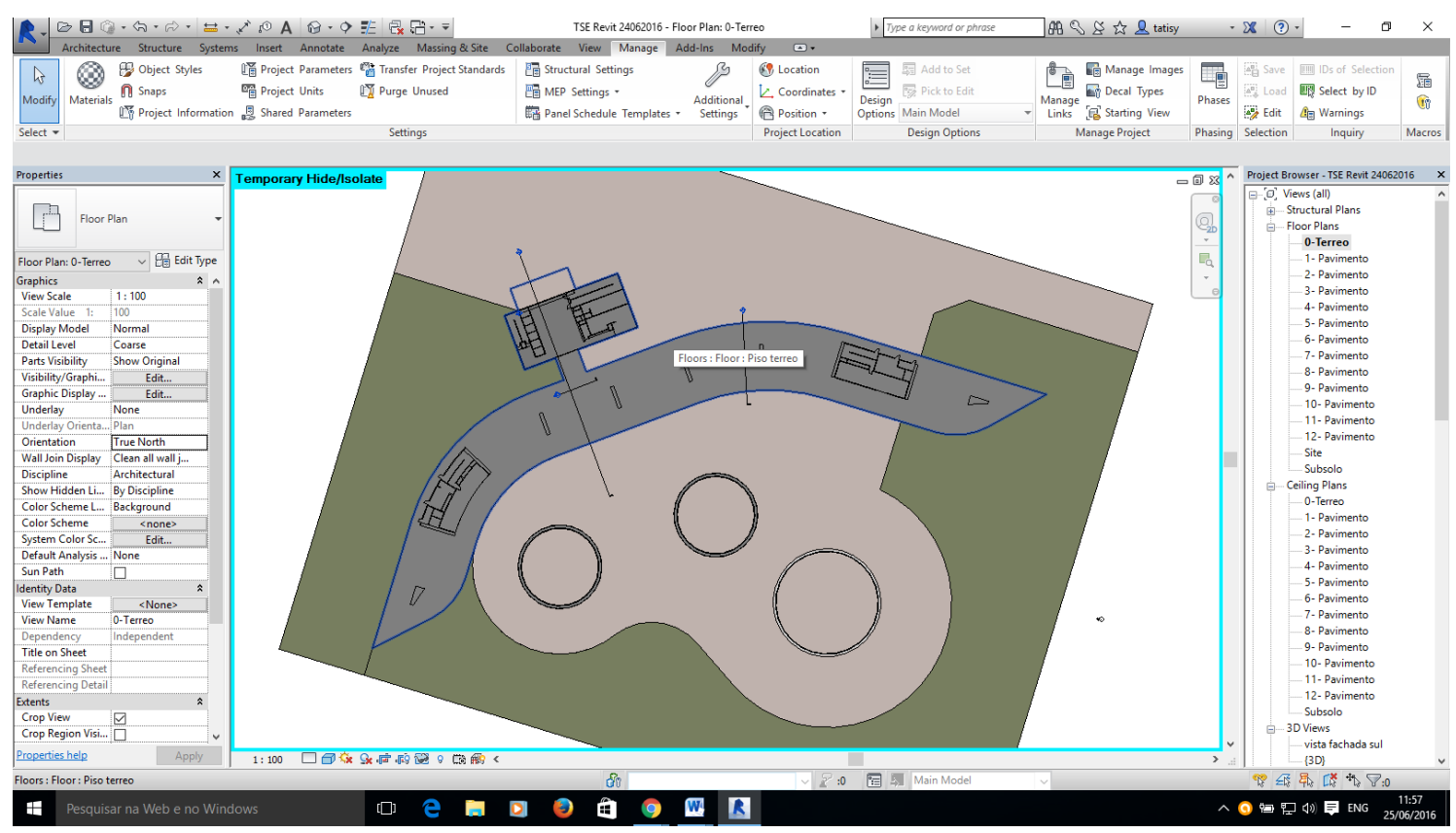

Figura 48: Norte Verdadeiro

Fonte: autoria nossa

\subsubsection{ESTUDOS DO CAMINHO DO SOL E SOMBRA}

O estudo do caminho do sol e sombras no Revit foram realizados no solstício de inverno (21 de junho), solstício de verão ( 21 de dezembro), equinócio de outono (21 de março) e equinócio de primavera (21 de setembro) no ano de 2016. Estes dados são para o hemisfério sul onde o Brasil está localizado, no hemisfério norte acontece situacão inversa. No equinócio o dia e a noite tem igual duração e marca o inicio da primavera ou outono. Os solstícios marcam o início do verão ou inverno. Vale informar que os dias dos solstícios e equinócios podem variar de acordo com o ano. Os horários utilizados para a simulação foram às 8 horas, 10 horas, 12 horas, 15 horas e 17 horas.

Os comandos no Revit utilizados para estudo do caminho solar e de sombras foram: Selecionar o "Sun Path On" > "Sun Setting"> "Still". O comando "Shadows On" deve ser ativado para visualização das sombras.

Ao selecionar o comando "Sun Setting" é aberta uma caixa de dialogo ilustrada na figura 47 onde foram inseridas as datas e horas. Acrescenta-se que através do comando "Sun Setting" é possível selecionar a opção "Single Day" onde é possível criar um vídeo para o caminho solar em um determinado dia ou a opção "Multi-Day" para simulação de vários dias. As figuras de 50 a 53 representam o estudo do caminho do sol e sombras executado no Revit. 


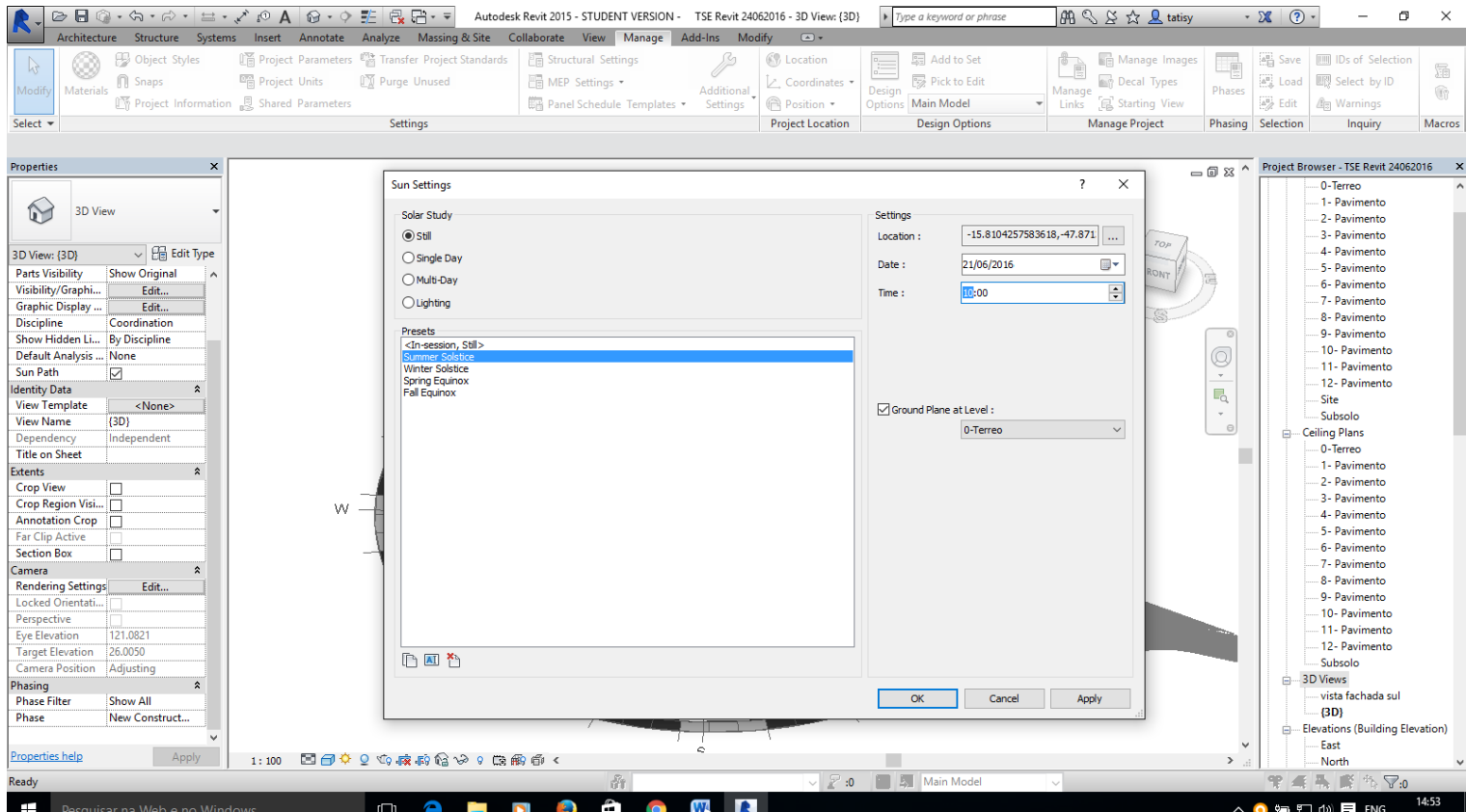

Figura 49: Caixa de Diálogo "Sun Setting".

Fonte: autoria nossa.
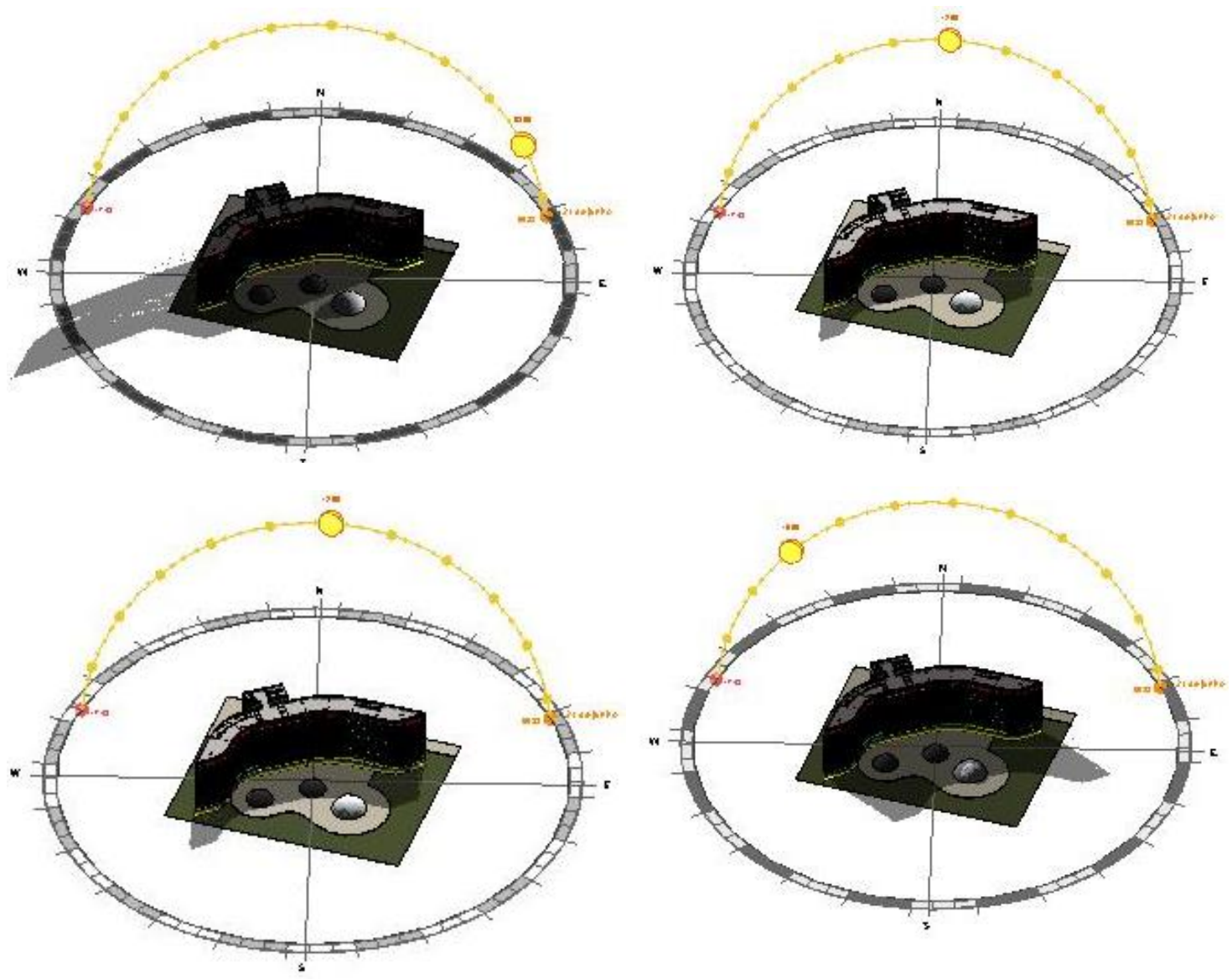


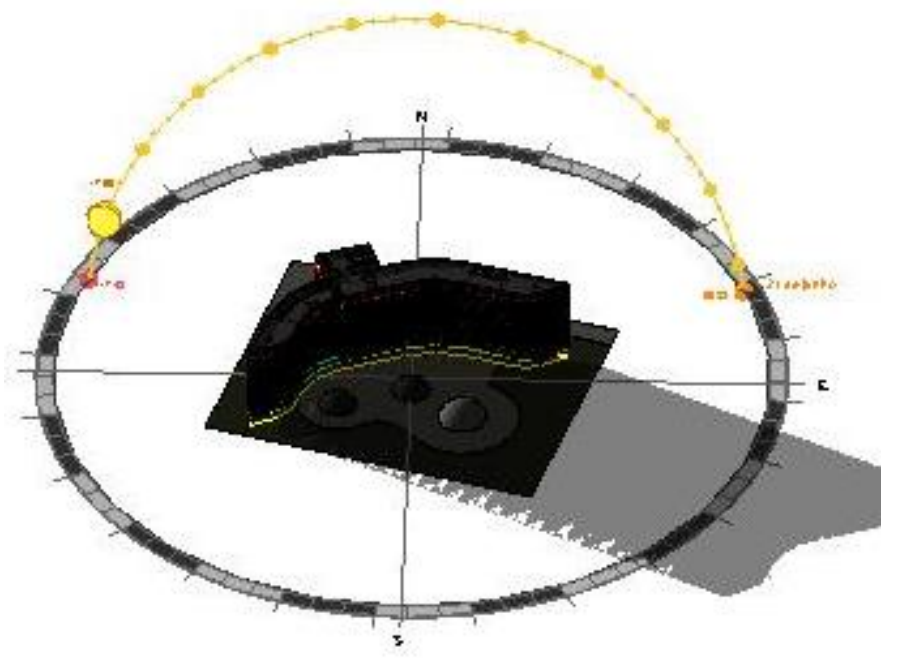

Figura 50: Caminho Solar e Sombras às 8, 10, 12,15 17 horas respectivamente solstício de inverno Fonte: autoria nossa

No solstício de inverno (21 de junho) de 2016 às oito horas a projeção de sombra está localizada maior parte na fachada sudoeste. Às dez, doze, quinze e dezessete horas a projeção de sombra encontra-se concentrada na fachada sul com uma projeção crescente. Constatamos que no solstício de inverno a fachada sul encontra-se mais protegida contra os raios solares diretos.
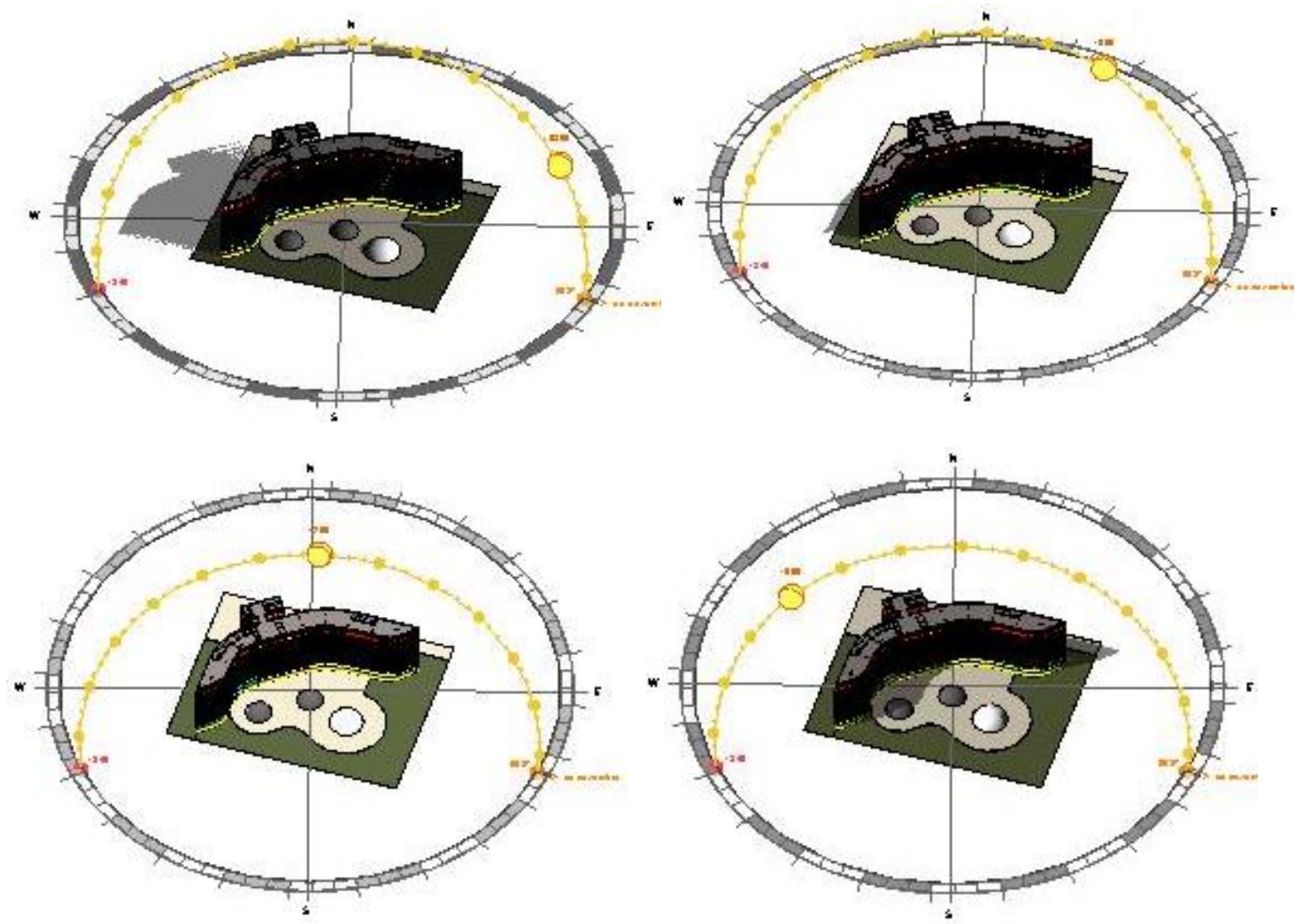


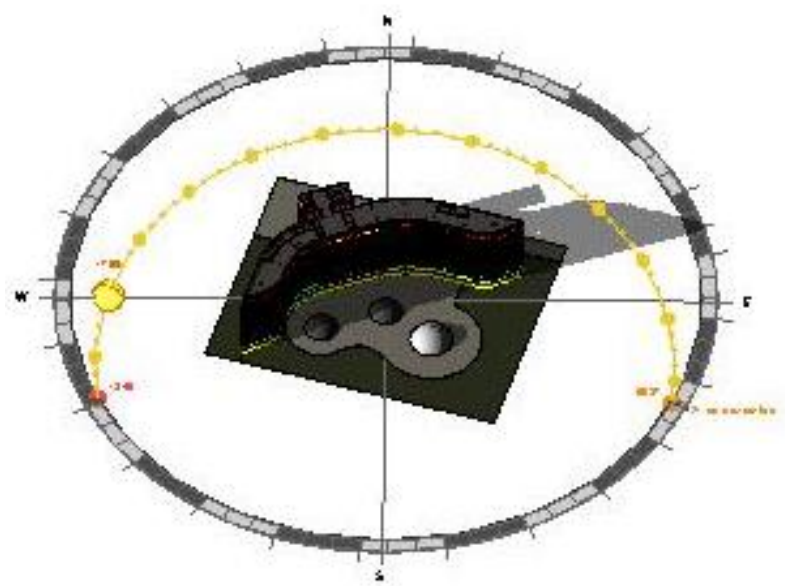

Figura 51: Caminho Solar e Sombras às 8, 10, 12,15 17 horas respectivamente solstício de verão. Fonte: autoria nossa.

No solstício de verão (21 de dezembro) de 2016 às oito horas a projeção de sombra está localizada na fachada noroeste. As dez horas a sombra continua voltada para fachada noroeste contudo com uma menor projeção. Ao meio dia quase não se verifica sombras nas fachadas. As quinze e dezessete horas a projeção de sombra encontra-se voltada para as fachadas leste e sul.
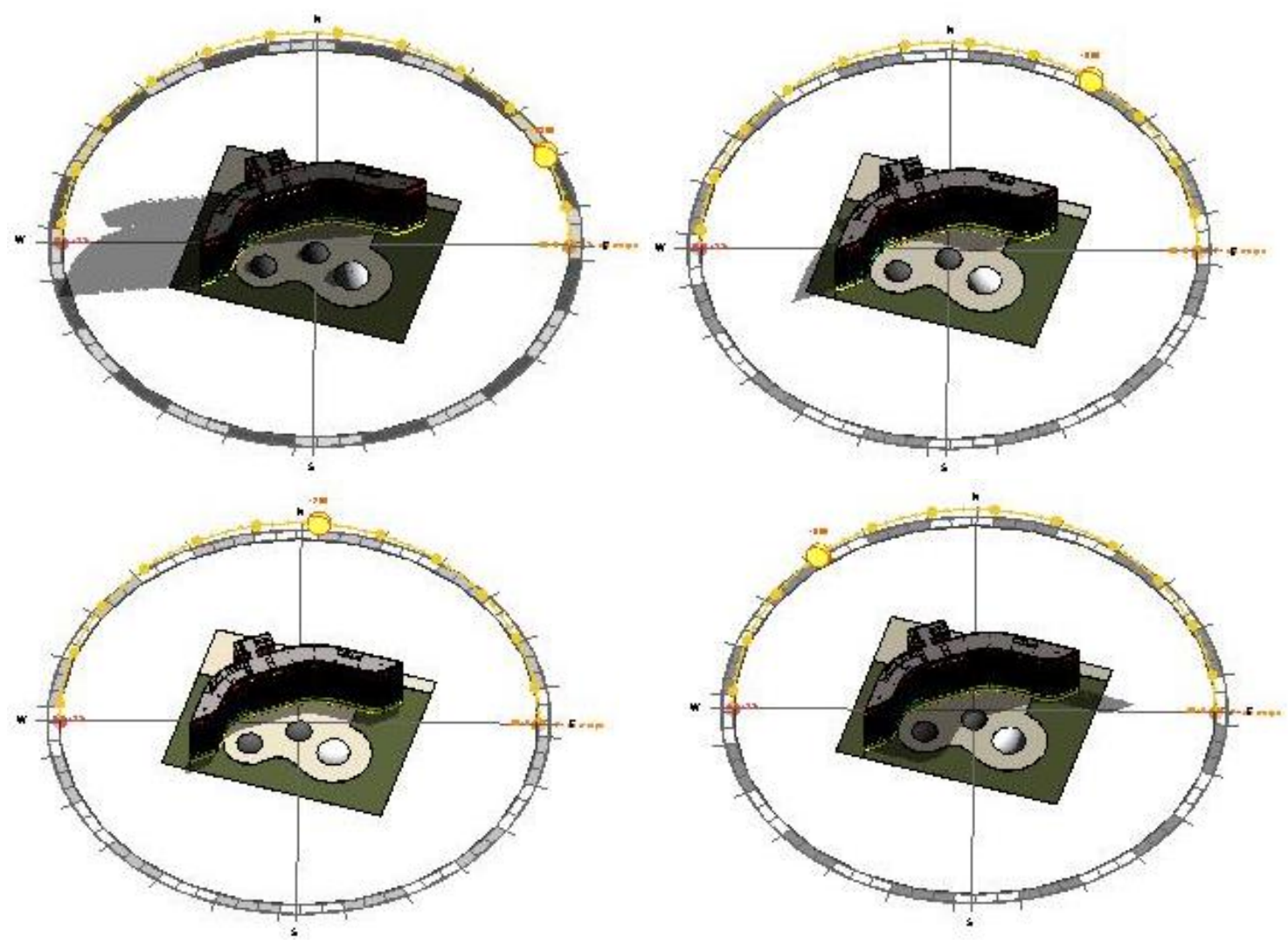


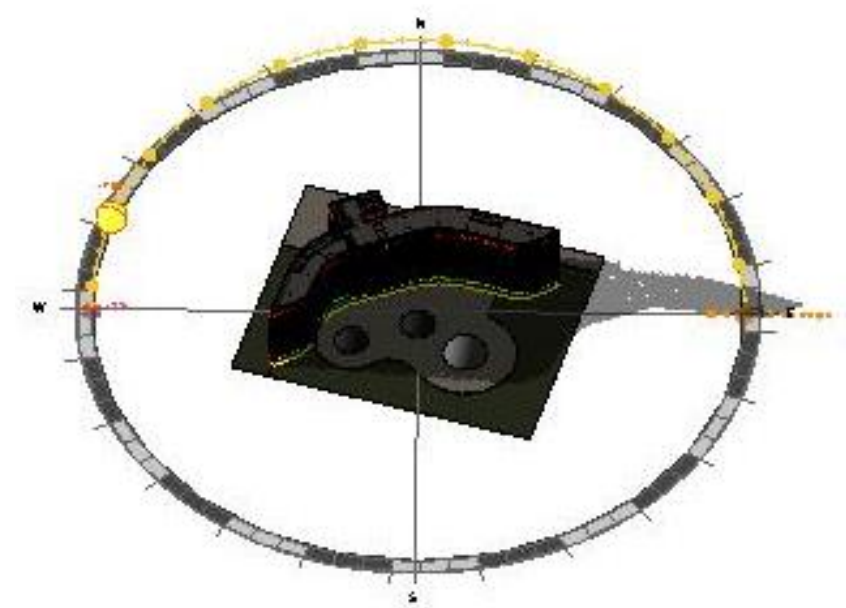

Figura 52: Caminho Solar e Sombras às 8, 10, 12,15 17 horas respectivamente equinócio /outono Fonte: autoria nossa

No equinócio de outono (21 de março) de 2016 às oito horas a projeção da sombra encontra-se voltada para fachada oeste. Às dez horas a sombra continua voltada para fachada oeste, mas em menor projeção. Ao meio dia quase não verifica-se sombra nas fachadas do TSE. Já às quinze e dezessete horas a sombra está voltada para as fachadas sul e leste. Portando pela manhã de oito às doze horas a fachada oeste é a mais protegida contra as luz solar direta e de doze às dezessete horas as fachadas sul e leste recebem maior projeção de sombra.
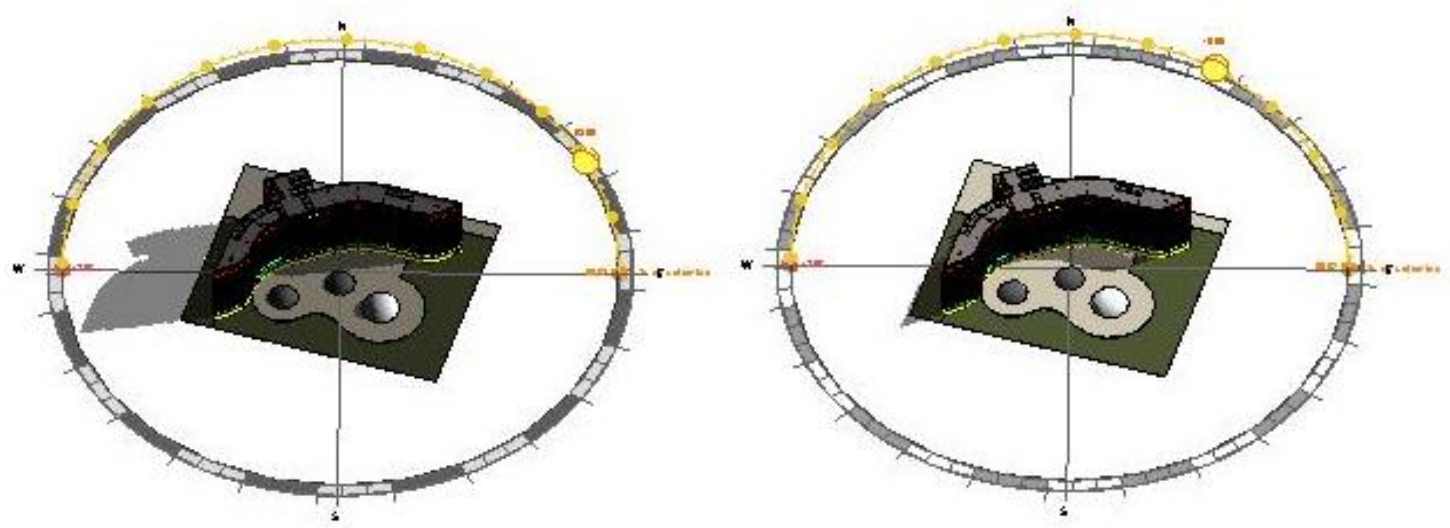

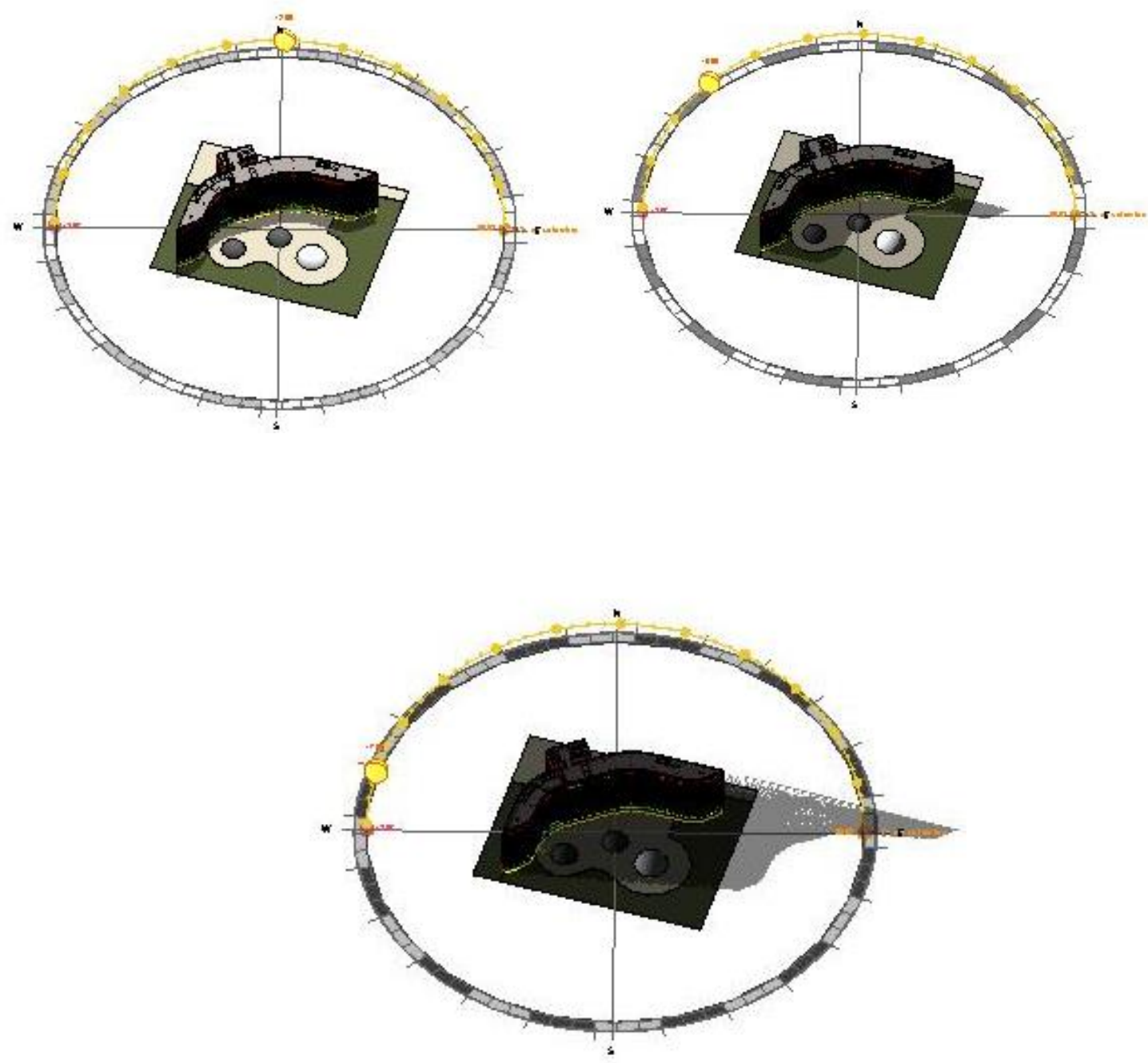

Figura 53: Caminho Solar / Sombras às 8, 10, 12,15 e 17 horas respectivamente equinócio /primavera. Fonte: autoria nossa.

No equinócio de primavera (21 de setembro) de 2016 às oito e dez horas a projeção da sombra encontra-se voltada para fachada oeste. Ao meio dia verifica-se uma pequena faixa de sombra voltada para fachada sul e às quinze e dezessete horas está sombra está localizada nas fachadas sul e leste.

Por meio do estudo do caminho solar e sombras conclui-se que a fachada que recebe maior incidência de sombra é a sul principalmente no período da tarde. E a fachada menos sombreada ao longo do ano é a norte.

A Simulação do caminho solar e projeção das sombras no Revit é muito semelhante ao realizado pelo software "standalone" Ecotect. Ambos os softwares disponibilizam destas simulações à qualquer horário do dia e data do ano. Está simulação é realizada de forma rápida em menos de 3 minutos e não é necessário instalação de plug-in no Revit. 


\subsubsection{SIMULAÇÃO DA ILUMINÂNCIA}

A norma NBR-5413/1992 - Iluminância de Interiores / Especificações da ABNT - Associação Brasileira de Normas Técnicas refere-se aos níveis de iluminância mínimos e médios para as diferentes tarefas visuais. Iluminância é a luz incidente, não visível, medida em lúmen por metro quadrado que corresponde a um lux. O conceito detalhado de iluminância encontra-se no item 2.5, página 26 desta Dissertação.

\begin{tabular}{|c|c|c|}
\hline \multicolumn{3}{|c|}{ Iluminância por classe de tarefa visual } \\
\hline Classe & Iluminância & Tipo de atividade \\
\hline \multirow{4}{*}{$\begin{array}{l}\text { A - lluminação geral para } \\
\text { área usadas } \\
\text { ininterruptamente ou com } \\
\text { tarefas visuais simples. }\end{array}$} & $20-30-50$ & Áreas públicas com arredores escuros. \\
\hline & $50-75-100$ & Orientaçăo simples para permanência curta. \\
\hline & $100-150-200$ & Recintos não usados para trabalhos contínuos: depósitos \\
\hline & $200-300-500$ & $\begin{array}{l}\text { Tarefas com requisitos visuais limitados trabalho bruto de } \\
\text { maquinário, auditórios. }\end{array}$ \\
\hline \multirow{2}{*}{$\begin{array}{l}\text { B-lluminaç̃óo geral para } \\
\text { área de trabalho }\end{array}$} & $500-750-1000$ & $\begin{array}{l}\text { Tarefas com requisitos visuais normais, trabalho média de } \\
\text { maquinário, escritórios. }\end{array}$ \\
\hline & $1000-1500-2000$ & $\begin{array}{l}\text { Tarefas com requisitos visuais especiais, gravação manual, } \\
\text { inspeçăo, indústria de roupas. }\end{array}$ \\
\hline \multirow{3}{*}{$\begin{array}{l}\text { C-lluminação adicional } \\
\text { para tarefas visuais dificeis. }\end{array}$} & $2000-3000-5000$ & $\begin{array}{l}\text { Tarefas visuais exatas e prolongadas, eletrônica de tamanho } \\
\text { pequeno. }\end{array}$ \\
\hline & $5000-7500-10000$ & Tarefas visuais muito exatas, montagem de microeletro̊nicos. \\
\hline & $10000-15000-20000$ & Tarefas visuais muito especiais, cirurgia. \\
\hline
\end{tabular}

Tabela 1: Iluminância por Classe de Tarefa Visual Fonte: NBR-5413/ 1992

Os cálculos da iluminância no Revit foram realizados no solstício de inverno (21 de junho) e solstício de verão (21 de dezembro) no ano de 2016. Os horários utilizados na simulação da iluminância foram às 8 horas, 10 horas, 12 horas, 15 horas e 17 horas.

Antes de iniciar o cálculo da iluminância é necessário salvar a vista na qual a simulação será realizada. Nesta tarefa foram utilizados os seguintes comandos do Revit: "View”> "3D View"> "Camera". Para salvar a vista é necessário acionar os comandos: "Unlocked 3D view"> "Save orientation and lock view". Então deve-se nomear a vista gerada no quadro de propriedades. 


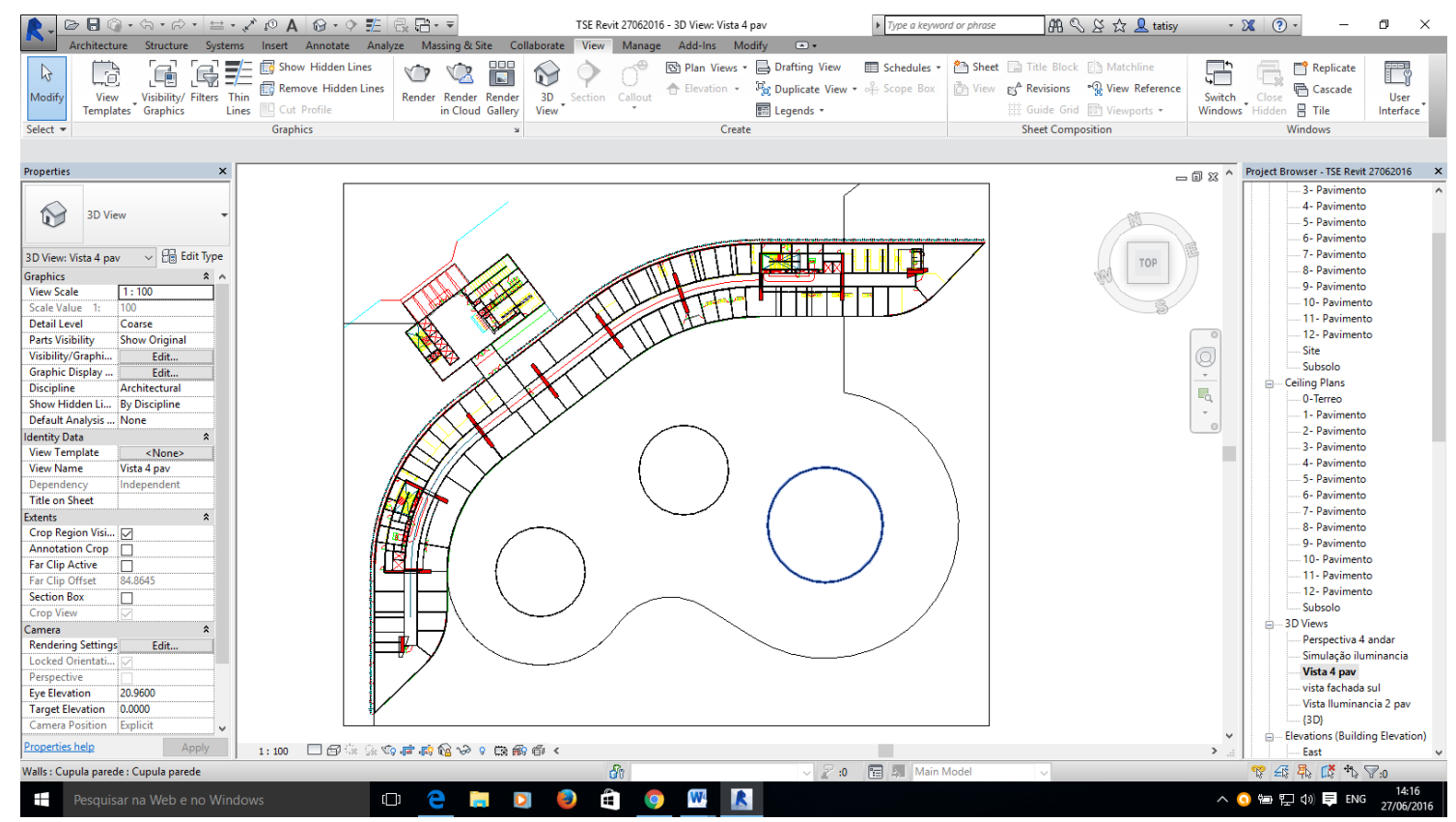

Figura 54: Vista utilizada para simulação da iluminância Fonte: autoria nossa

Posteriormente foi realizada a simulação da iluminância acionando os comandos: "View"> "Render in Cloud"< selecionar a opção "Iluminance". Depois disto, abre-se uma caixa de diálogo apresentada pela figura 53 em que é necessário acrescentar as informações de data e horário, modelo de céu (“Sky Model”) e legenda ("Legend"). Esta simulação foi realizada no serviço de nuvem da Autodesk 360 e durou menos de 10 minutos cada simulação.

O item "Sky Model" possui seis modelos diferentes do céu para simulação de iluminância, e também permite que especifique a intensidade do sol (irradiância). E o item "Legend" viabiliza determinar a unidade de medida entre Footcandles ou Lux. Neste item é necessário também fornecer os valores de Irradiância Direta Normal - DNI (Direct Normal Irradiance) e Irradiância Difusa Horizontal-DHI (Diffuse Horizontal Irradiance) da localização do projeto.

Irradiância Direta Normal - DNI é a quantidade de radiação solar perpendicular recebida por unidade de área em uma superfície, sem ocorrer distorções.

Irradiância Difusa Horizontal- DHI é a radiação solar dispersa e refletida incidente em uma superfície horizontal, excluindo a radiação solar direta (DNI). Também inclui radiação solar que é refletida pelo entorno, como topografia, cobertura do solo, edificações, etc.

Os valores de DNI e DHI devem estar na unidade W/m2. Estes valores podem ser encontrados em estudos sobre o clima ou por simulação realizada através do "Green 
Building Studio 360 rendering”. Para realização desta tarefa é necessário selecionar o comando "Run Energy Simulation" para análise energética do edifício. Vale informar que foram seguidos os comando para realização do cálculo enérgicos, contudo após um período de aproximadamente 10 minutos foi aberto uma caixa de dialogo informado que houve problemas com o serviço do "Energy Analysis" e não foi executada a simulação. Este procedimento foi repetido quatro vezes e não foi executada a simulação.

Um dos motivos pra a não realização da simulação energética é que a Autodesk lançou o plug-in "Insight 360" para simulação LN no Revit com integração do fluxos de trabalho do "Energy Analysis" e "Light Analysis Revit". Este assunto foi abordado de forma detalhada no item 6.5.7 desta dissertação.

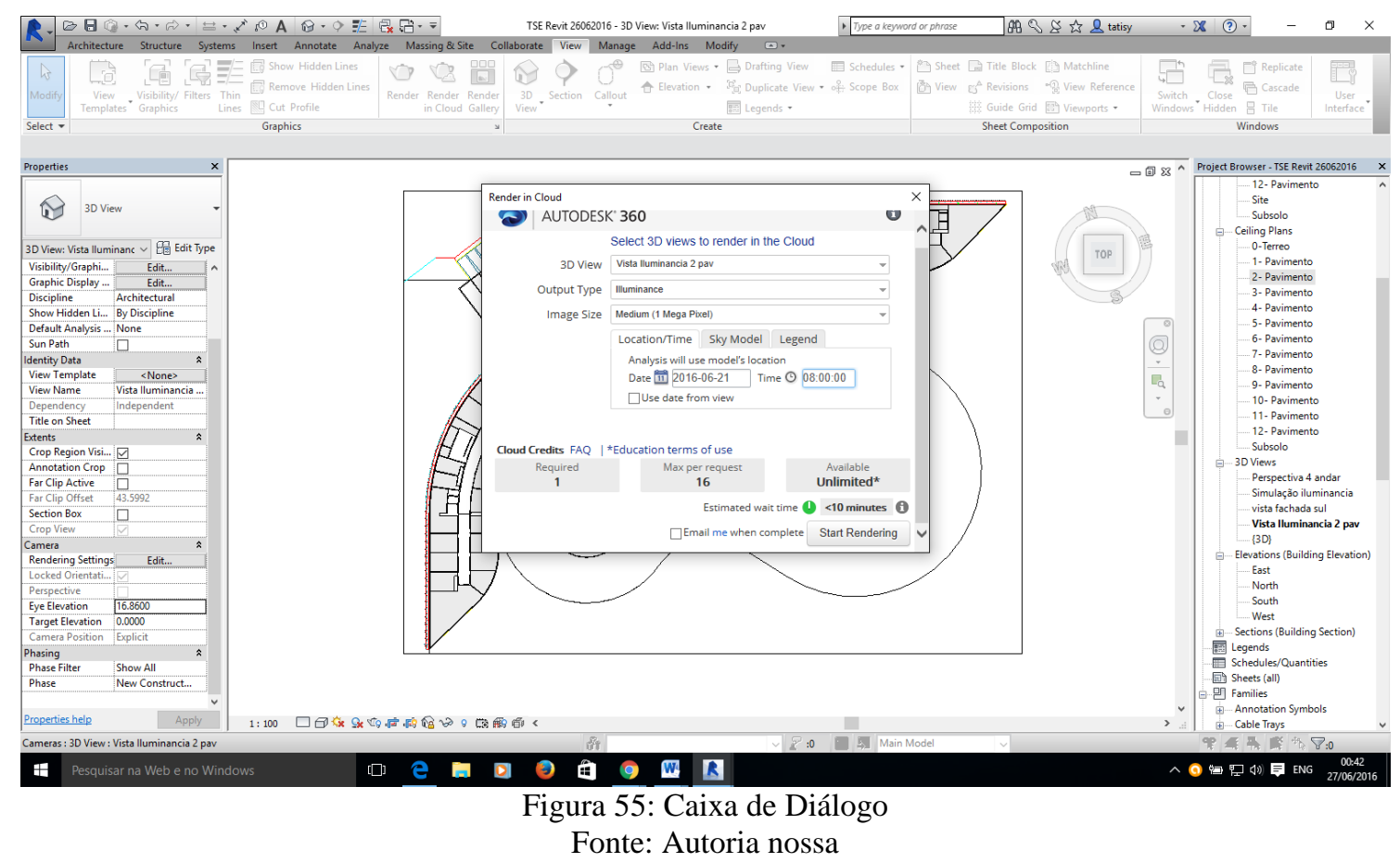

Caso não seja aberta uma caixa de dialogo informando que a simulação foi realizada é necessário acionar os comandos ("View" < "Render Gallery") para visualização dos resultados no "Autodesk A360 Rendering". As figuras 56 a 65 representam os resultados da iluminância em lux de diferentes horários e datas por meio do gráfico de cores ("false color") conforme legenda. 


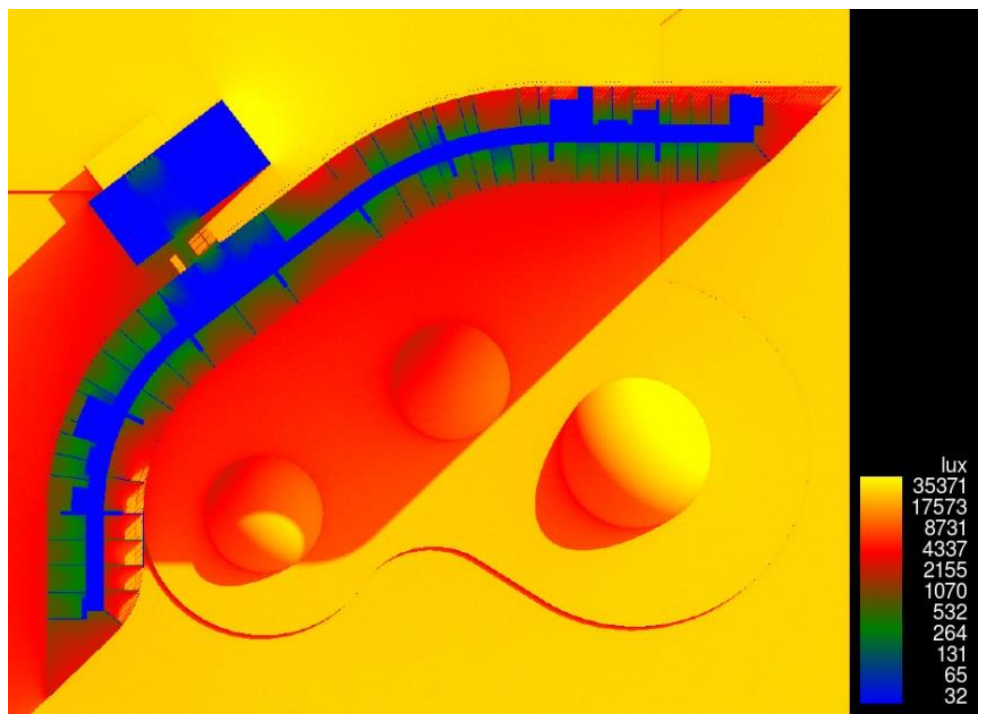

Figura 56: Simulação da iluminância solstício de inverno (21/06/2016) ás 8 horas Fonte: Autoria nossa

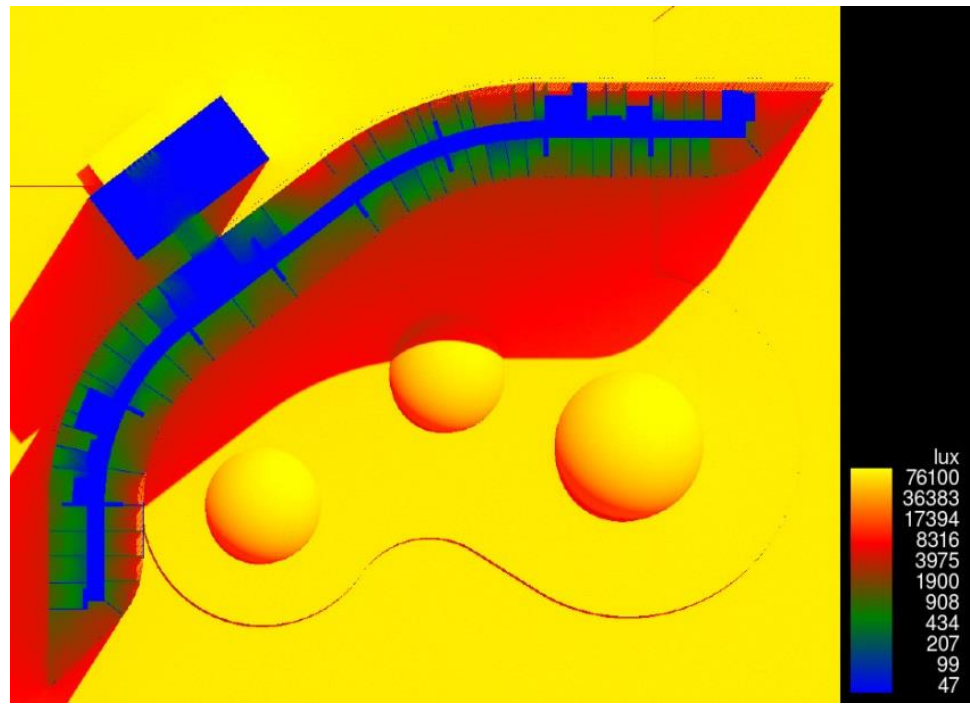

Figura 57: Simulação da iluminância solstício de inverno (21/06/2016) às 10 horas Fonte: autoria nossa

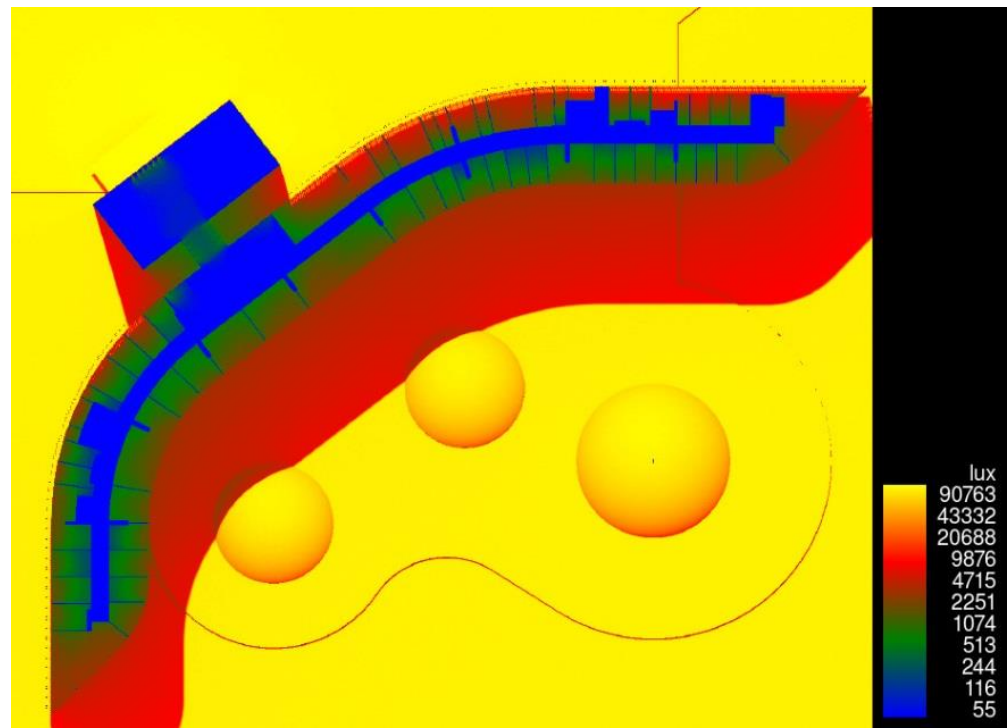

Figura 58: Simulação da iluminância solstício de inverno (21/06/2016) às 12 horas Fonte: autoria nossa 


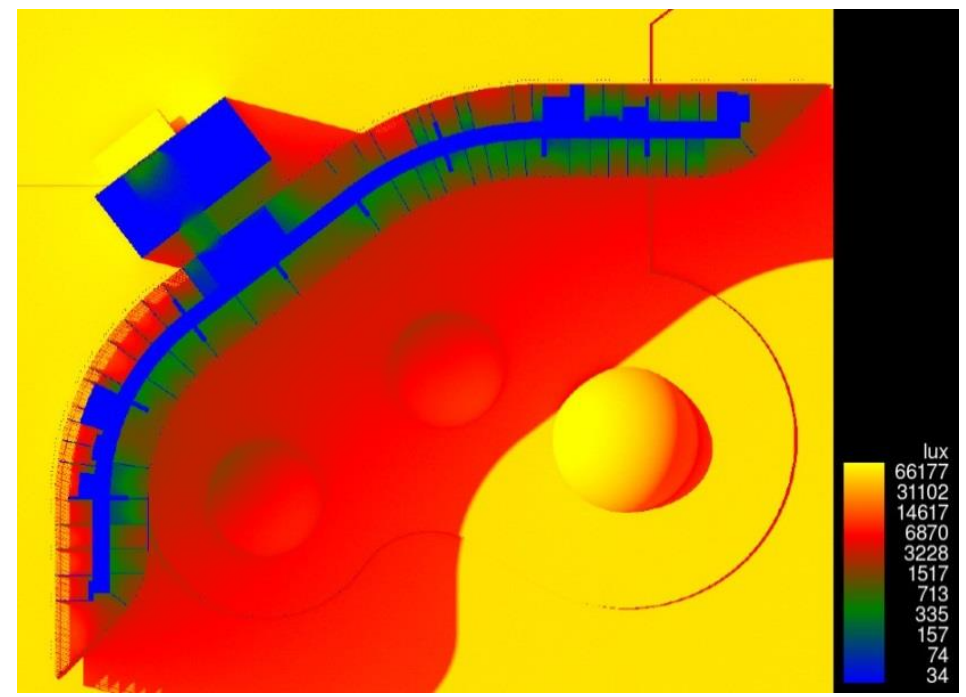

Figura 59: Simulação da iluminância solstício de inverno (21/06/2016) às 15 horas Fonte: autoria nossa

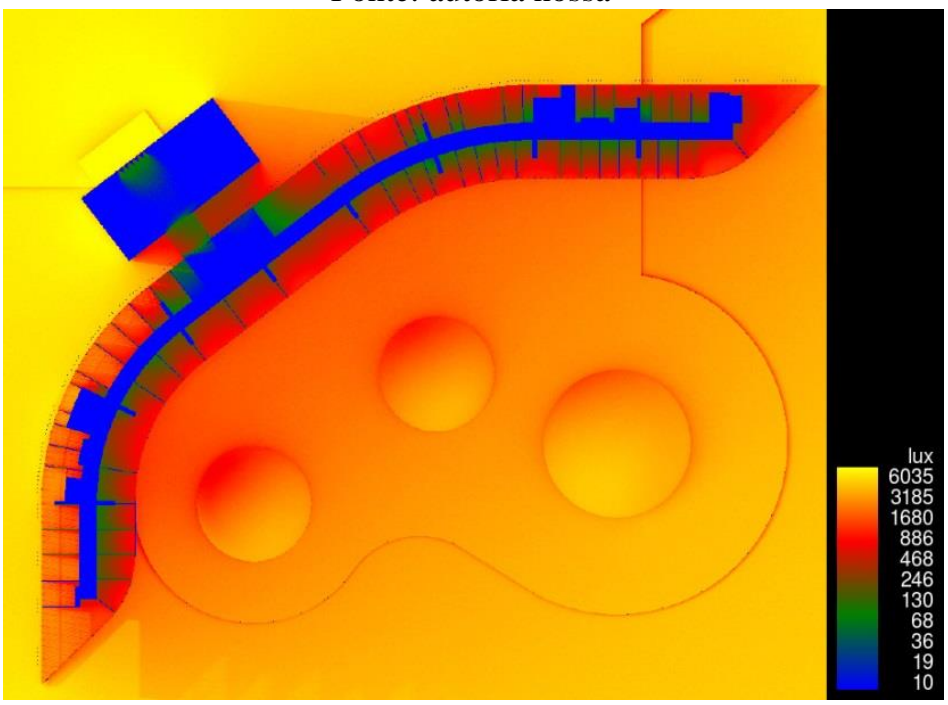

Figura 60: Simulação da iluminância solstício de inverno (21/06/2016) às 17 horas Fonte: autoria nossa

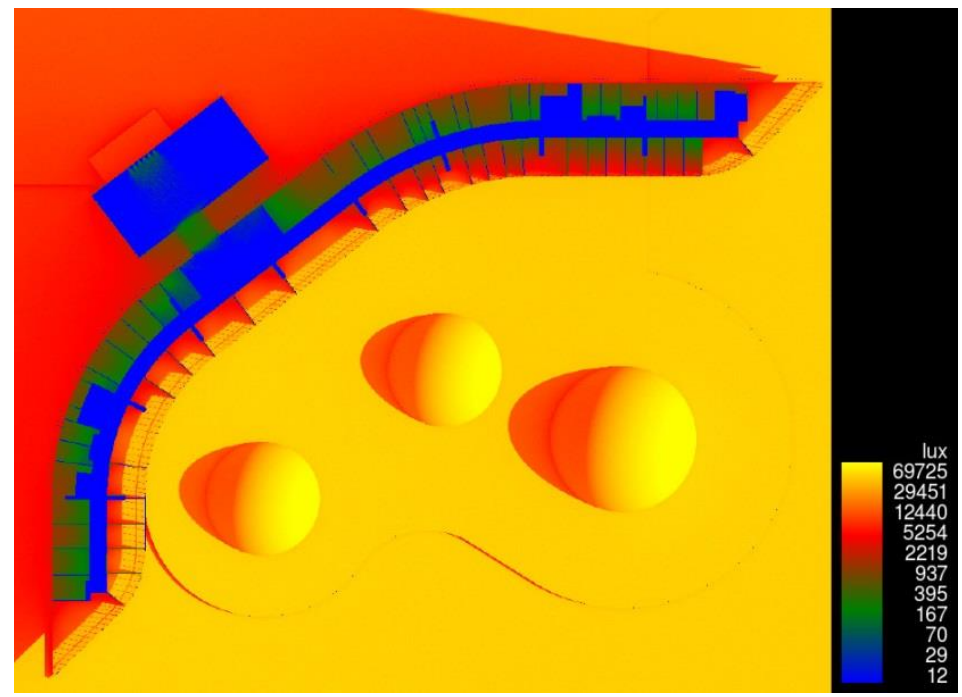

Figura 61: Simulação da iluminância solstício de verão (21/12/2016) às 8 horas Fonte: autoria nossa 


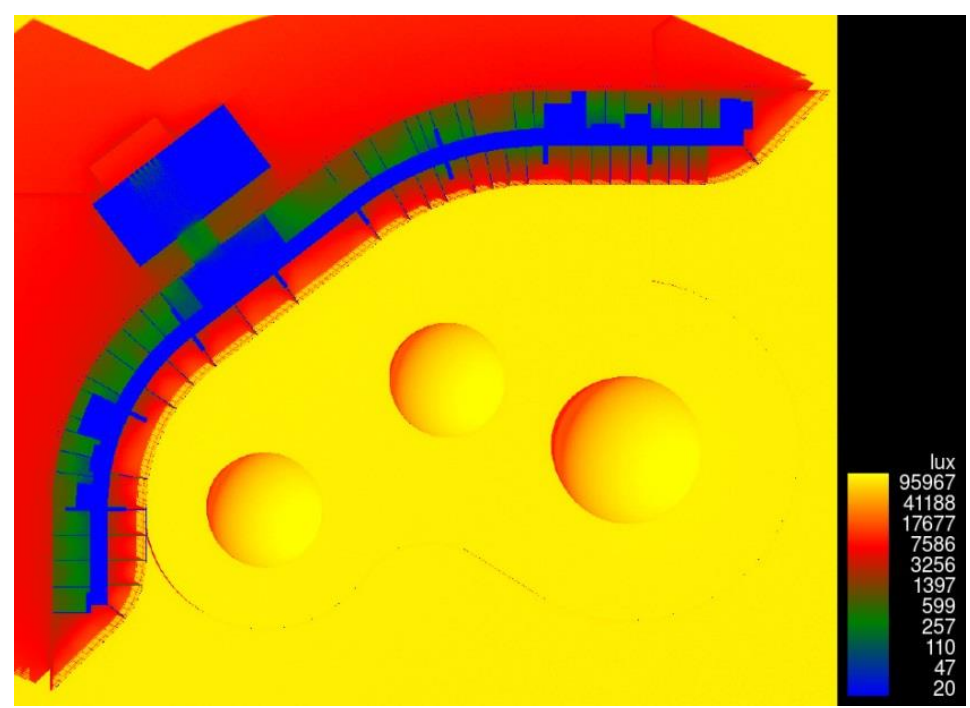

Figura 62: Simulação da iluminância solstício de verão (21/12/2016) às 10 horas

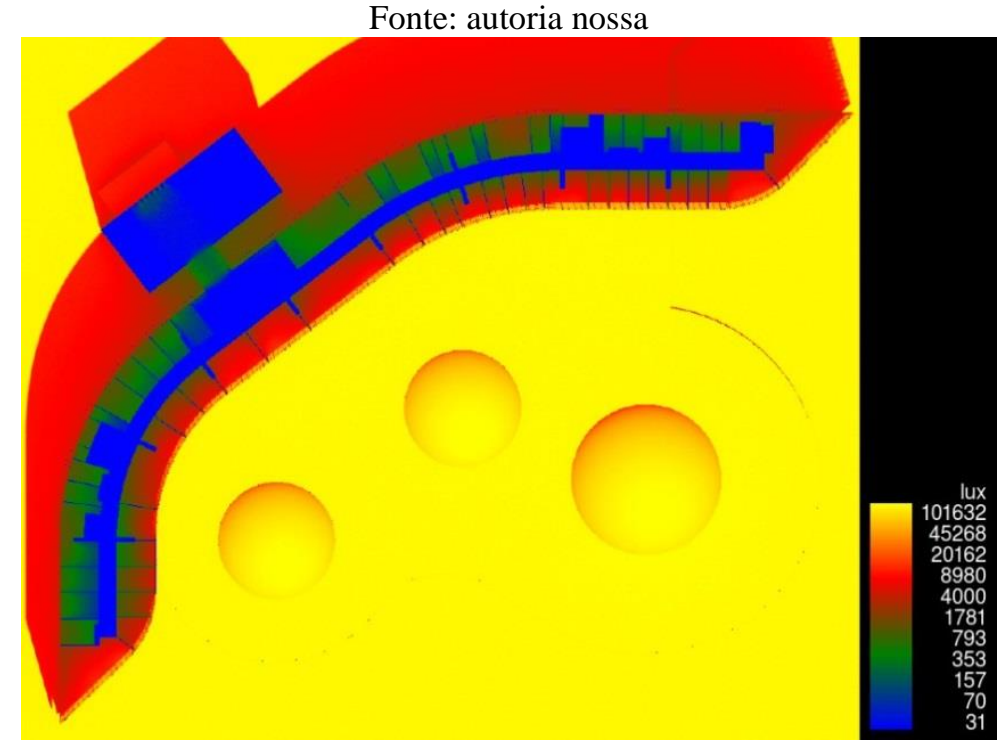

Figura 63: Simulação da iluminância solstício de verão (21/12/2016) às 12 horas Fonte: autoria nossa

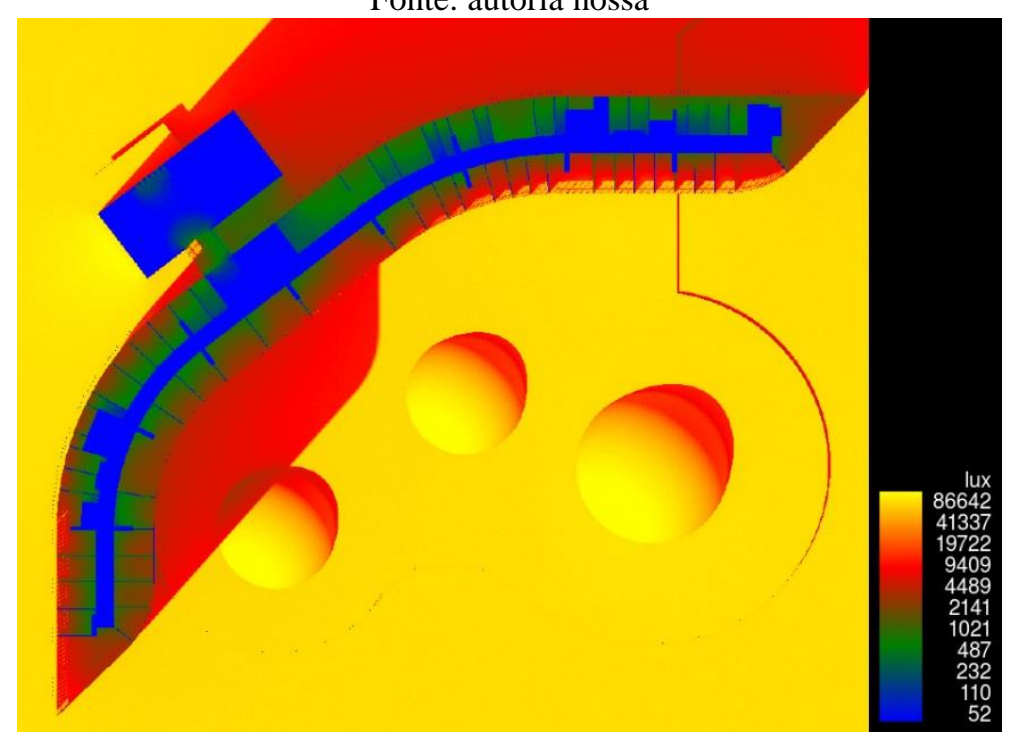

Figura 64: Simulação da iluminância solstício de verão (21/12/2016) às 15 horas Fonte: autoria nossa 


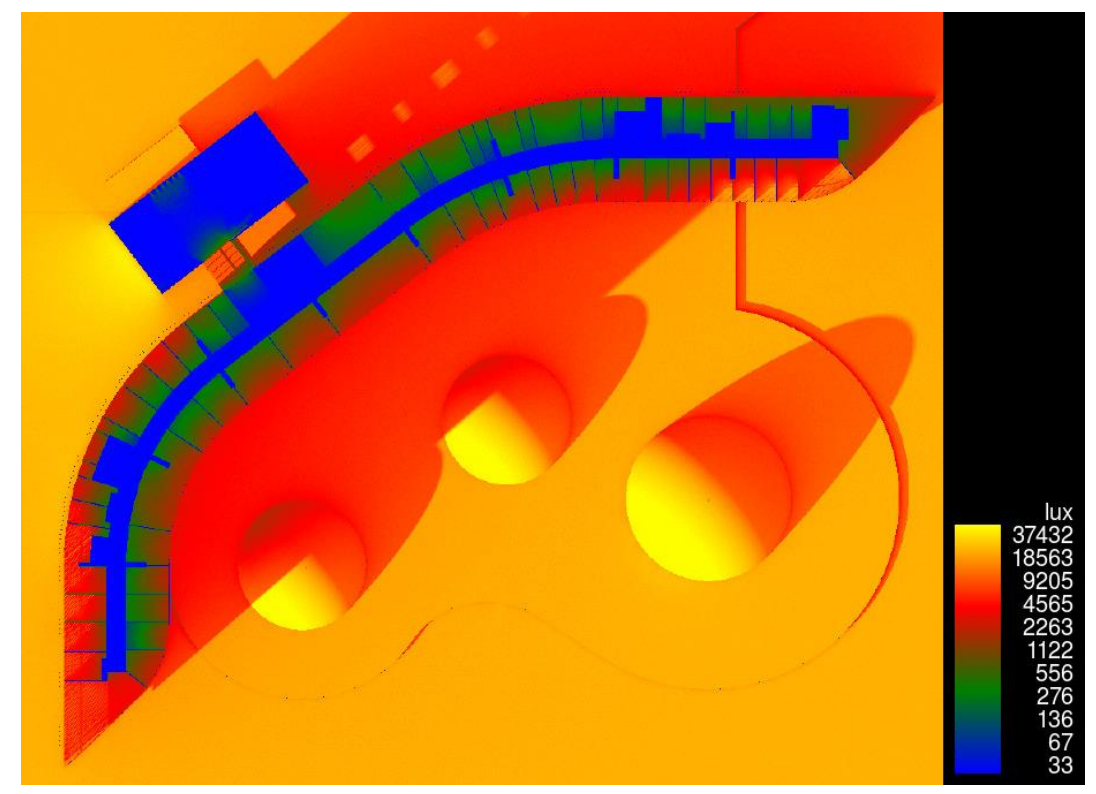

Figura 65: Simulação da iluminância solstício de verão (21/12/2016) às 17 horas Fonte: autoria nossa

Para a simulação da iluminância não houve a necessidade de instalação de um plug-in. As figuras geradas pelas simulações mostram valores diferenciados de lux conforme data do ano e horário do dia. No gráfico de cores os valores mais próximos do azul possuem menor nível de iluminância e os mais próximos do amarelo maior nível de iluminância. $\mathrm{O}$ ambiente interno do corredor (na cor azul) possui o menor nível de iluminância visto não possuir aberturas para LN. Já os ambientes mais próximos da fachada de vidro possuem níveis elevados de iluminância, podendo inclusive ocasionar ofuscamento no ambiente de trabalho, em alguns períodos do dia. Por meio de visitas no local foi verificado a instalação de persianas com elevado grau de reflexão luminosa (superior a 60\%) para amenizar a luz natural direta. Verificou-se que na maioria das salas as persianas ficam fechadas durante todo o dia em virtude do ofuscamento gerado e muitas vezes, é necessário o uso de iluminação artificial.

A simulação da iluminância realizada no Revit conforme descrita neste item se difere da realizada pelo simulador ambiental individual Ecotect em alguns aspectos. A simulação da iluminância realizada no Revit possibilita fazer o cálculo em vista, portanto para a simulação de cada pavimento é necessário salvar vista para cada pavimento e gerar a simulação dos pavimentos desejados para análise. No Ecotect não é necessário salvar as vistas sendo disponível a simulação de todos os pavimentos de uma só vez. Outra questão importante é que no Revit sem o plug-in é gerada a simulação para apenas uma determinada data e hora, portanto para uma análise detalhada do edifício é necessário gerar várias simulações para cada data e hora desejada. O Ecotect 
disponibiliza de recurso para simulação da iluminância durante o ano todo e diferentes horas do dia em uma única simulação.

Não foi possível alterar as cores da legenda apenas valores máximos e mínimos de lux.

Vale lembrar que a complexidade do modelo e a precisão dos dados são determinantes para o tempo gasto na simulação da iluminância tanto no Revit quanto Ecotect. Outra questão importante é que estas simulações foram geradas com as ferramentas já disponíveis no Revit sem a instalação de um plug-in para simulação da LN. No item 6.5.7 foram detalhados os recursos para simulação da LN por meio de plug-in instalado no Revit.

\subsubsection{SIMULAÇÃO DO FATOR DE LUZ DO DIA- FLD}

O Fator de Luz Natural - FLN, também chamado de Fator de Luz do Dia - FLD (“Daylight Factor - DF”), é um valor em percentual que representa a relação de proporção entre a quantidade de luz natural em um determinado ponto no interior de uma construção e a referente ao espaço exterior desobstruído. Esta proporção demonstra que a quantidade de luz natural em um espaço interno é alterada simultaneamente com a variação da luminosidade do céu. Os fatores que influenciam o fator de luz natural são: tamanho e posicionamento das aberturas, tipo de vidro, obstruções externas, materiais utilizados no edifício e cores (VIANNA E GONÇALVES, 2001, p.109). Para o cálculo matemático do FLD utiliza-se a seguinte expressão:

$$
\% \mathrm{FLD}=(\mathrm{Ei} / \mathrm{Eo}) \times 100
$$

$\mathrm{Ei}=$ iluminância interior em um ponto considerado.

Eo = iluminância exterior procedente de um céu sem obstruções.

A figura abaixo é uma representação ilustrativa do resultado de uma simulação do FLD realizada no Ecotect através do gráfico de cores. No gráfico de cores, as áreas mais próximas da cor amarela significa maior quantidade de iluminância e os pontos mais afastados com a cor mais próxima do azul, menor quantidade de iluminância em relação ao ambiente externo. 


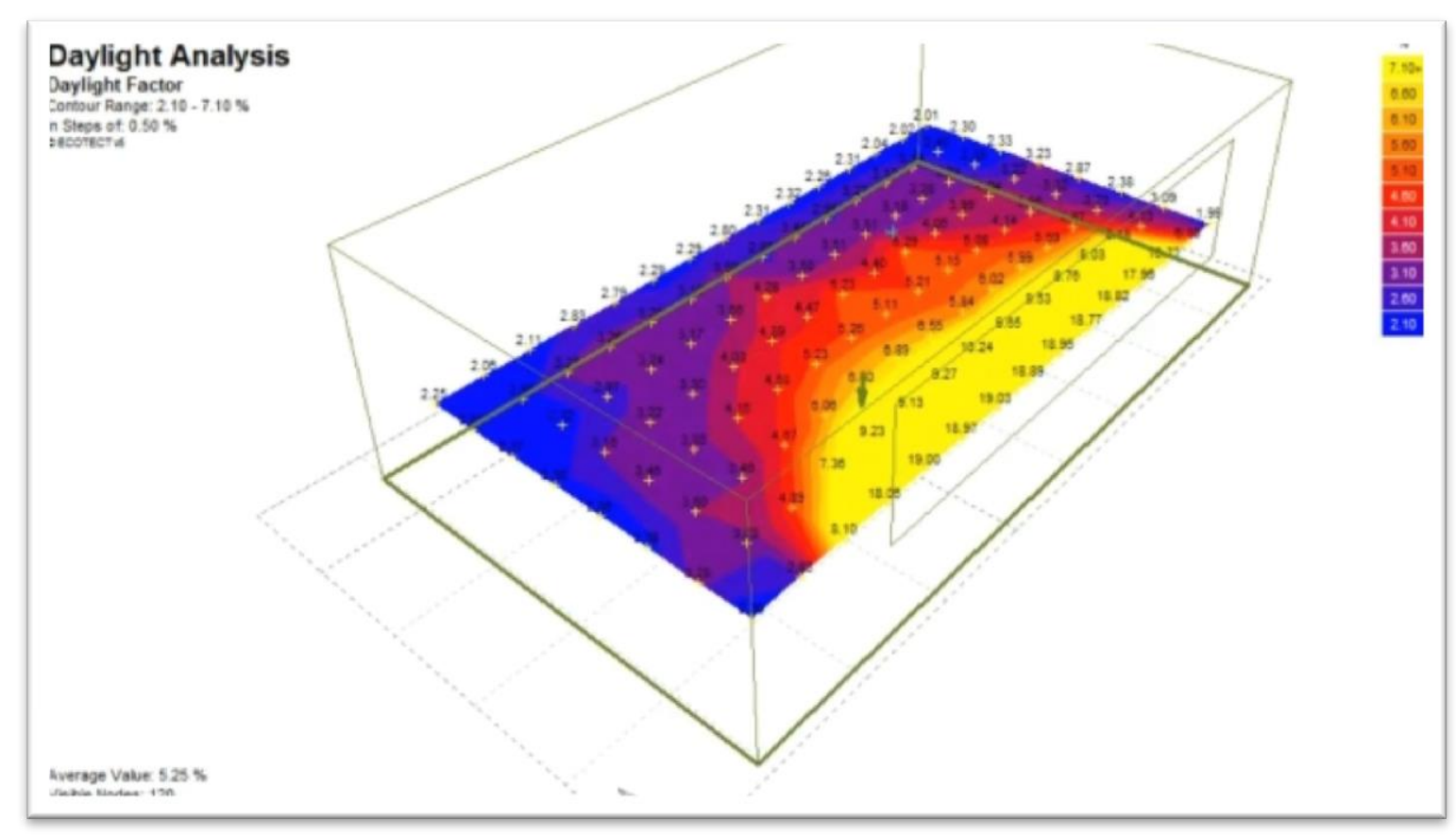

Figura 66: Simulação no Ecotect do Fator de Luz Natural

Fonte:http://sustainabilityworkshop.autodesk.com/buildings/measuring-light levels?_ga=1.182613542.1659709118.1447953474

O Fator de Luz do Dia pode ser simulado também no Revit, os comandos iniciais são os mesmos usados no cálculo da iluminância. Primeiro deve-se salvar a vista na qual a simulação será realizada depois é necessário selecionar os comandos "View"> "Render in Cloud" < selecionar a opção "Iluminance" e inserir os dados de data, hora e localização do projeto. O que difere neste comando é que ao selecionar a opção do modelo de céu "Sky Model" deve-se escolher a opção "Daylight Factor Sky" para a simulação do FLN. Ao escolher o "Daylight Factor Sky", os resultados são gerados em porcentagens. 


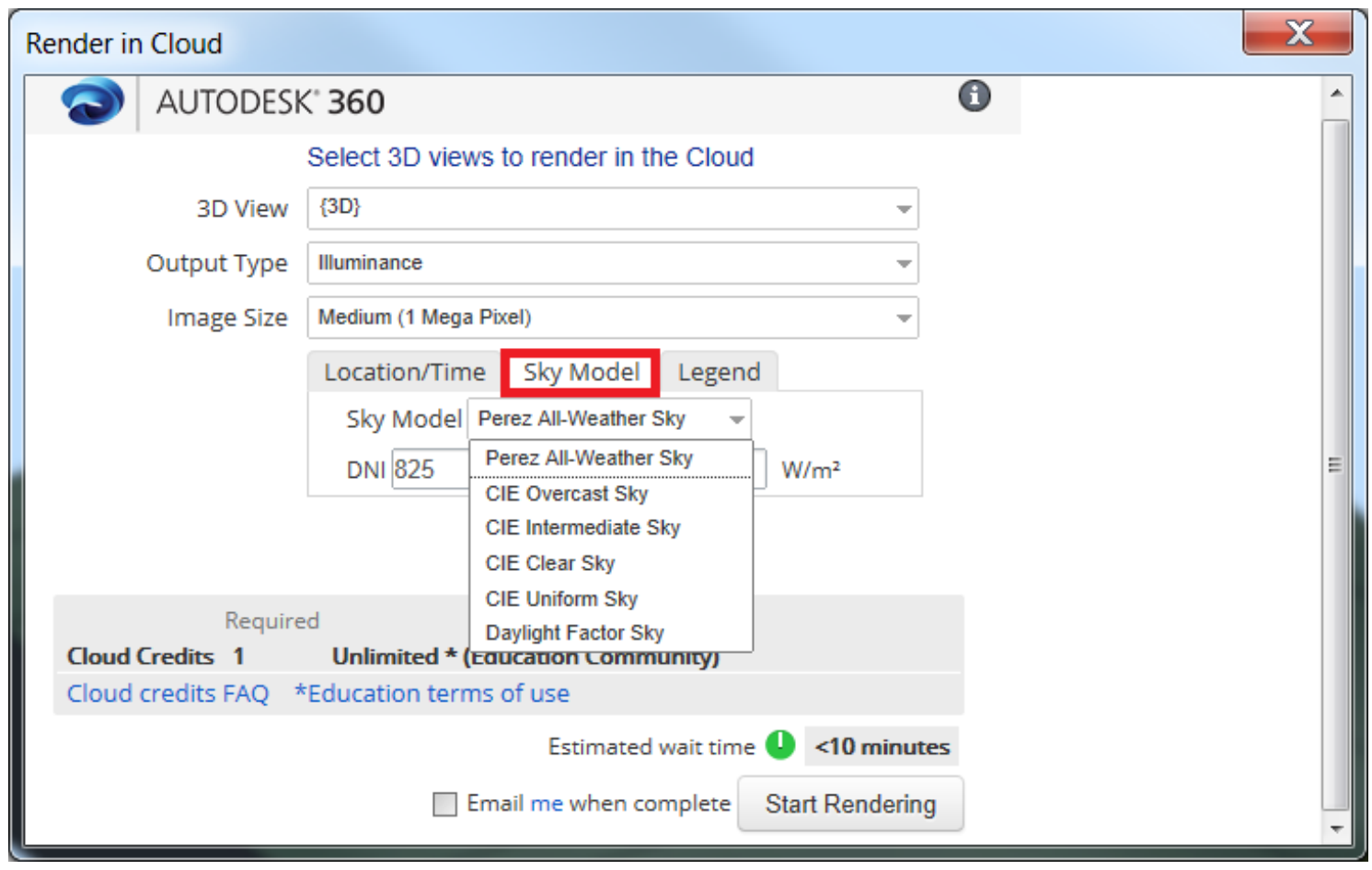

Figura 67: Caixa de dialogo para selecionar simulação do fator de luz do dia Fonte:http://help.autodesk.com/view/BUILDING_PERFORMANCE_ANALYSIS/ENU/?guid=GUIDA93DC4A2-7017-4191-BFE0-915CCEC4D3AD

Foi realizada uma simulação do FLD no solstício de inverno (21/06/2016) no Revit e os resultados encontram-se nas figuras abaixo. 


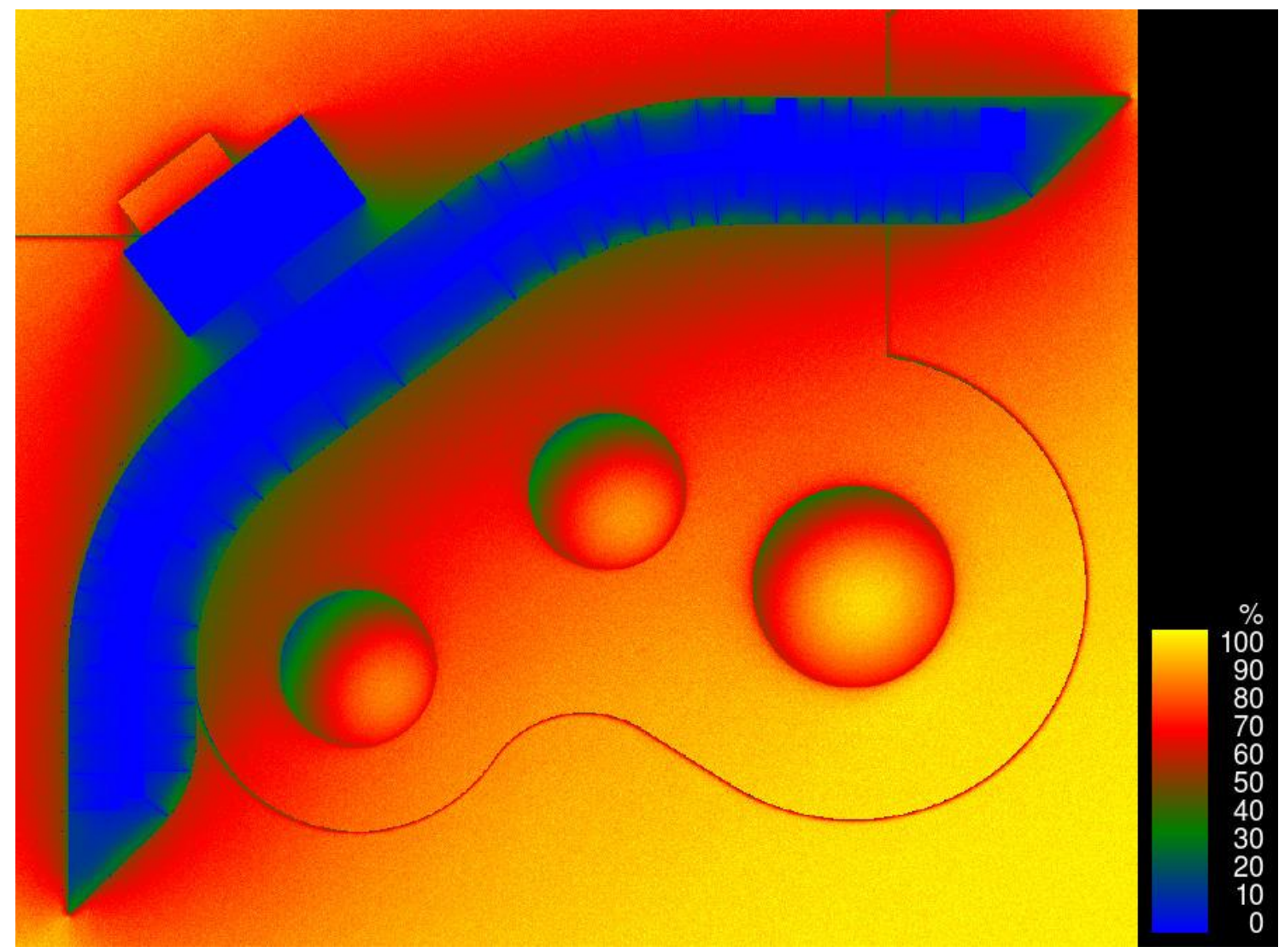

Figura 68: Simulação do FLD na data de 21 de junho às 8 horas.

Fonte: autoria nossa.

\subsubsection{SIMULAÇÃO DA LUMINÂNCIA}

A simulação da luminância, que é a luz refletida visível, ainda não está disponível no Revit 2016, sendo uma desvantagem em relação ao Ecotect que disponibiliza esta simulação em sua interface. Visto que cada superfície possui diferente capacidade de reflexão dos raios incidentes, certa iluminância pode gerar diferentes luminâncias. O cálculo da luminância é um importante parâmetro que pode indicar níveis de desconforto e ofuscamento visual. (Disponível em: http://help.autodesk.com/view/BUILDING_PERFORMANCE_ANALYSIS/ENU/?guid =GUID-15D6945E-B38C-44D3-ABA4-2428D77958BA. Acessado em 05/05/2016.)

\subsubsection{PLUG-IN PARA SIMULAÇÃO DA LUZ NATURAL NO REVIT}

O plug-in "Light Analysis Revit - LA/R" utiliza o serviço de nuvem da Autodesk 360 “Rendering” para realizar simulações da LN no Revit. O plug-in LA/R, disponível no site da Autodesk (http://www.autodesk.com/products/lighting-analysisrevit/overview) foi instalado dentro do Revit 2015 com sucesso. Contudo, ao utilizar o 
LA/R para fazer simulação da LN por meio dos comandos : "Analyse" > "Light"> "Run Analysis", a seguinte mensagem foi aberta na caixa de diálogo: "Este "plug-in" expirou. Por favor, verifique se há uma atualização". A figura 69 ilustra a caixa de diálogo aberta ao executar a simulação da LN no Revit.

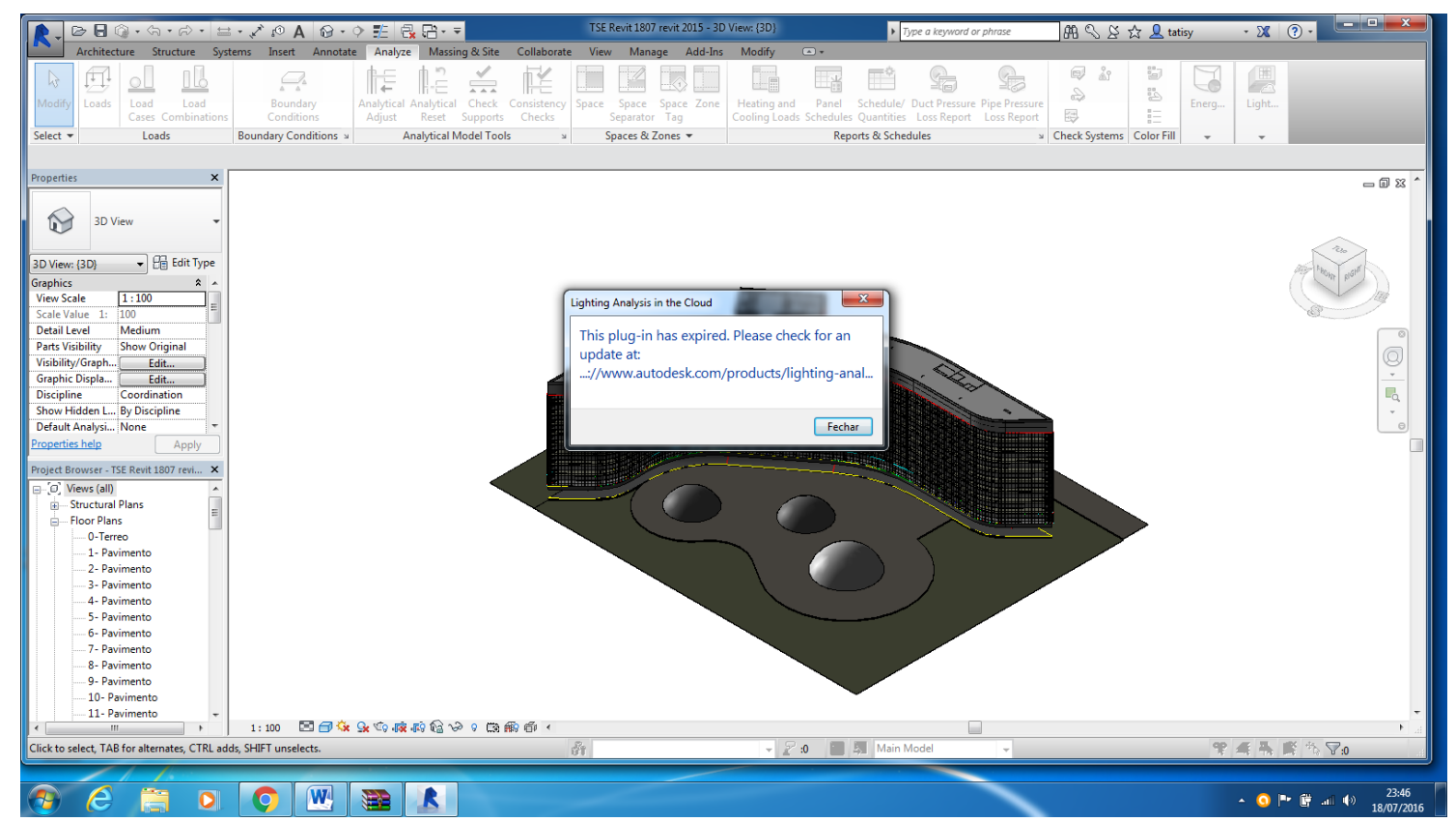

Figura 69: Simulação da LN por meio do LA/R.

Fonte: autoria nossa.

Visto que o plug-in LA/R não está mais disponível para simulação da LN, foi necessário instalar o plug-in "Insight 360" da Autodesk para análise da LN no Revit. Este plug-in foi disponibilizado em 1 de Julho de 2016, podendo ser instalado apenas no Revit 2016 e 2017. O “Insight 360” é um plug-in para o Revit que integra os fluxos de trabalho do "Energy Analysis" e o LA/R. (Disponível em: http://blogs.autodesk.com/insight360/updated-lighting-analysis-plugin-for-insight-360/. Acessado em 05/07/2016.)

Segundo é informado pelo site da Autodesk o "Insight 360" permite a visualização da radiação solar nas superfícies de elementos de massa ou de construção com os novos fluxos de trabalho de análise da LN. (Disponível em: http://www.autodesk.com.br/products/revit-family/features/architecturaldesign/autodesk-insight-360. Acessado em : 06/07/2016.)

Em virtude da simulação da LN no "Insight 360" ser uma tecnologia muito recente (disponibilizada em 1 de julho de 2016), não houve tempo hábil para um maior aprofundamento nesta pesquisa, mas verifica-se grande potencialidade para trabalhos 
futuros. Contudo houve a preocupação de gerar simulações com este plug-in, uma vez que se trata de uma ferramenta promissora para análise da LN.

Depois da instalação do plug-in da Autodesk denominado o "Insight 360", foram realizadas simulações de iluminância por meio dos comandos: "Analyse"> "Lighting"> "New". Ao selecionar estes comandos foi aberta uma caixa de diálogo que permitiu inserir a data e hora da simulação, selecionando as opções para simulação da iluminância de todos os pavimentos do TSE e ao ativar a opção "use weather data" são informados os valores de DNI e DHI da localização de projeto. A simulação foi realizada no solstício de inverno às oito horas. O resultado da simulação encontra-se na figura 70 .

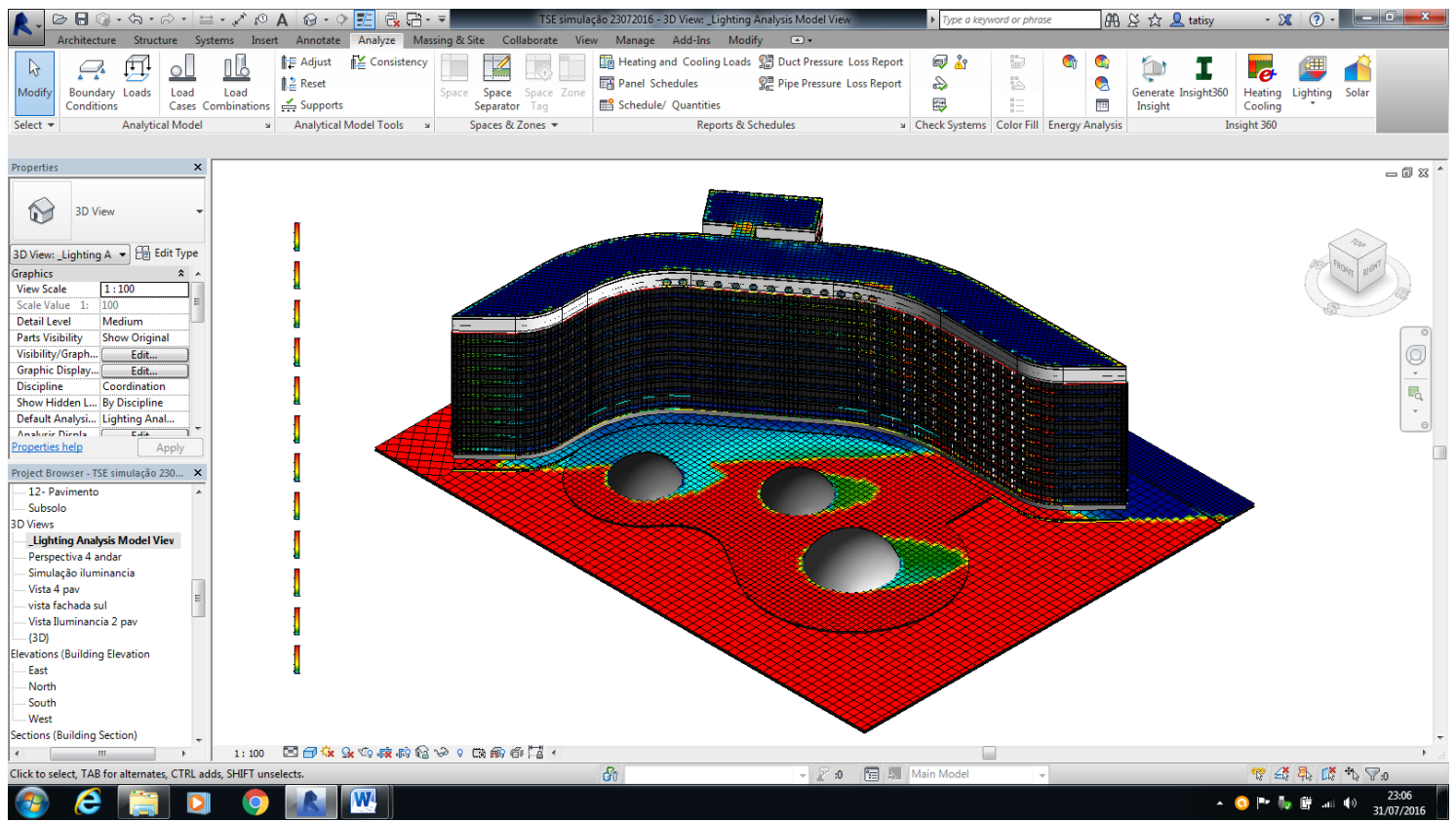

Figura 70: Simulação iluminância no "Insight 360". Fonte: autoria nossa.

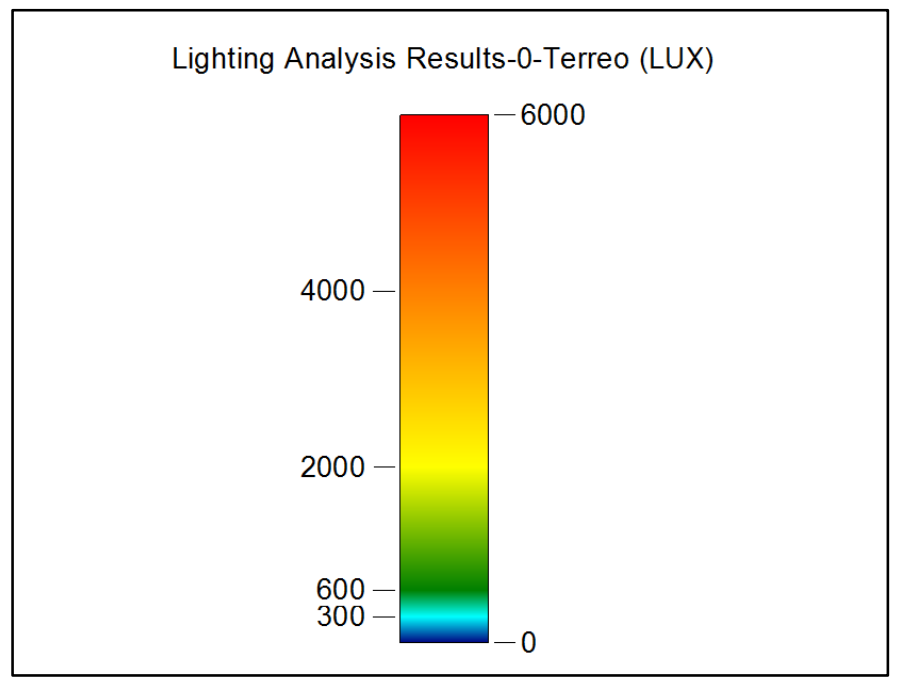

Figura 71: Legenda simulação iluminância Fonte: autoria nossa 
A imagem acima representa a simulação da iluminância por meio do gráfico de cores onde os valores de lux são: azul de 0 a 300 lux, ciano de 300 a 600 lux, verde de 600 a 2000 lux, amarelo de 2000 a 6000 lux. Vale lembrar que as cores e valores da legenda podem ser editados conforme interesse do usuário. Para edição da legenda é necessário selecioná-la e em seguida ativar o comando "edit style", no qual é aberta uma caixa de diálogo para sua formatação. Destacamos o fato de que os valores máximo e mínimo de lux não podem ser modificados. Para visualização dos resultados conforme planta baixa dos pavimentos do projeto é necessário salvar a vista de cada pavimento e depois abrir os resultados da simulação por meio dos comandos: "analyze"> "lighting".

\section{6- AVALIAÇÃO DOS RESULTADOS OBTIDOS}

Foi elaborado um quadro contendo os recursos integrados no sistema BIM (software Revit) para avaliação da $\mathrm{LN}$, tomando como referência os recursos disponíveis no software de simulação ambiental individual, Ecotect Analysis. O Ecotect foi utilizado para estabelecer um "benchmark" de padrão de qualidade, o "standard", a partir do qual avaliou-se os recursos de simulação da LN já presentes no Revit. Para o estabelecimento de um "benchmark" recorreu-se à documentação e conhecimento (pessoal) do Ecotect para estabelecer os requisitos mínimos de avaliação das simulações realizadas no Revit. Considerando ainda que o Ecotect é mais antigo que o Revit no que se refere às simulações da LN.

A seguir elaboramos uma análise conclusiva verificando se realmente é possível realizar estudos e simulações dos componentes da $\mathrm{LN}$ sem exportar o projeto para o simulador ambiental individual, conforme apresentado no site da Autodesk, e descrito no item 5.2 desta Dissertação. 


\section{QUADRO GERAL DE RESULTADOS DA AVALIAÇÃO DO REVIT UTILIZANDO COMO BENCHMARK O ECOTECT}

\section{Modelagem do projeto}

\begin{tabular}{|c|c|c|}
\hline $\begin{array}{l}\text { Critérios de } \\
\text { Avaliação }\end{array}$ & REVIT sem plug-in & ECOTECT \\
\hline $\begin{array}{l}1.1 \text { Possibilita modelar o } \\
\text { projeto diretamente no } \\
\text { ambiente de simulação? }\end{array}$ & $\begin{array}{l}\text { Sim. O Revit foi desenvolvido para utilizar o sistema BIM e desde } \\
2015 \text { também possibilita a simulação da LN em sua interface. }\end{array}$ & $\begin{array}{l}\text { Sim. As ferramentas de modelagem são limitadas, o Ecotect não é um } \\
\text { software desenvolvido para modelagem de projeto seu principal } \\
\text { objetivo é a simulação ambiental. }\end{array}$ \\
\hline $\begin{array}{l}\text { 1.2 Permite inserir } \\
\text { arquivos do AutoCAD } \\
\text { para elaboração do } \\
\text { modelo do projeto? }\end{array}$ & $\begin{array}{l}\text { Sim. Disponibiliza ferramentas para importar o projeto do AutoCAD } \\
\text { para o Revit de duas formas: "Import CAD"e "Link CAD". Os } \\
\text { formatos possíveis de importação pelo comando "Import CAD" são: } \\
\text { DWG, DXF, DGN, SAT e SKP. Por meio do comando "Link CAD", } \\
\text { alterações no projeto do AutoCAD refletem no arquivo do Revit. }\end{array}$ & $\begin{array}{l}\text { Sim. Disponibiliza ferramentas para importar projetos do AutoCAD } \\
\text { para o Ecotect via arquivos DXF. }\end{array}$ \\
\hline $\begin{array}{l}1.3 \text { Modela os } \\
\text { componentes da } \\
\text { construção? }\end{array}$ & $\begin{array}{l}\text { Sim. O Revit trabalha com ferramentas de modelagem dos } \\
\text { componentes da construção que estão organizados em famílias. Como } \\
\text { exemplo podemos citar família de paredes, portas, janelas, lajes, entre } \\
\text { outras. }\end{array}$ & Não. Trabalha com volumetrias, linhas e vetores. \\
\hline $\begin{array}{l}\text { 1.4 Permite definir } \\
\text { relações Paramétricas? }\end{array}$ & $\begin{array}{l}\text { Sim. Este é um dos principais fundamentos dos sistemas BIM } \\
\text { conforme relatado no item } 6.48 \text { desta dissertação. }\end{array}$ & $\begin{array}{l}\text { Sim. Disponibiliza algumas funções paramétricas, contudo muito mais } \\
\text { limitadas em relação àquelas disponíveis no Revit. }\end{array}$ \\
\hline $\begin{array}{l}1.5 \text { Trabalha com } \\
\text { modelagem paramétrica } \\
\text { baseada em objetos? }\end{array}$ & $\begin{array}{l}\text { Sim. O projeto nos sistemas BIM em vez de projetar uma instância de } \\
\text { elementos como parede, laje ou portas; define uma família de modelo } \\
\text { que possuem um conjunto de relações e regras para controlar os } \\
\text { parâmetros pelos quais estes elementos são gerados. Cada elemento } \\
\text { pode variar conforme contexto e normalmente o software disponibiliza } \\
\text { de um conjunto predefinido de famílias. }\end{array}$ & $\begin{array}{l}\text { Não. Trabalha com uma instância de elementos e não como família de } \\
\text { modelo. Cada elemento deve ser editado pelo usuário. }\end{array}$ \\
\hline $\begin{array}{l}1.6 \mathrm{Na} \text { modelagem da } \\
\text { fachada de vidro em } \\
\text { formato curvilíneo do TSE } \\
\text { houve limitação ou } \\
\text { simplificação da forma? }\end{array}$ & $\begin{array}{l}\text { Sim. As fachadas de vidro do TSE foram construídas por meio do } \\
\text { comando "curtain wall" (que é a família no Revit para projetar paredes } \\
\text { de vidro) em seguida foi selecionado na barra de "modify" a opção } \\
\text { "pick lines" onde utilizou-se a planta baixa de documentação do } \\
\text { projeto inserida no Revit, para construir o formato da fachada. Contudo } \\
\text { para definir a curva foi necessário definir uma largura do gride vertical } \\
\text { ("vertical grid") no guia de propriedade do Revit. Caso não tivesse } \\
\text { sido definidos a largura do gride vertical o software não entenderia a } \\
\text { parede como curva sendo projetada uma linha diagonal reta unindo as } \\
\text { duas pontas da curva. A fachada curva foi facetada em linha retas de }\end{array}$ & $\begin{array}{l}\text { O projeto do TSE não foi modelado no Ecotect em virtude do software } \\
\text { não estar mais disponível para uso. }\end{array}$ \\
\hline
\end{tabular}




\begin{tabular}{|c|c|c|}
\hline & $\begin{array}{l}\text { 1,25 metros que é espessura dos painéis e montantes do TSE, portanto, } \\
\text { houve simplificação da forma. }\end{array}$ & \\
\hline $\begin{array}{l}1.7 \text { Permite } \\
\text { interoperabilidade com } \\
\text { outros softwares? }\end{array}$ & $\begin{array}{l}\text { Sim. O Revit suporta os seguintes formatos de arquivo: DWG, DXF, } \\
\text { DGN, SAT, DWF/DWFx, ADSK (componentes do edifício), html } \\
\text { (áreas de relatório), FBX (para vialização 3D), gbXML, IFC, e ODBC } \\
\text { ("Open DataBase Connectivity”)". Permite interoperabilidade com } \\
\text { Ecotect por meio do arquivo gbXML. }\end{array}$ & $\begin{array}{l}\text { Sim. Importa formas geométricas de outros sistemas CAD via arquivos } \\
\text { DXF ou 3DS e com o Revit por meio do arquivo gbXML. }\end{array}$ \\
\hline \multicolumn{3}{|c|}{ 2. Especificações dos Atributos dos Componentes de Projeto } \\
\hline $\begin{array}{l}2.1 \text { Disponibiliza de } \\
\text { especificação de } \\
\text { materiais? }\end{array}$ & Sim, disponibiliza de especificações de materiais de forma detalhada. & $\begin{array}{l}\text { Sim, disponibiliza especificações de materiais, contudo com menor } \\
\text { grau de funcionalidades, precisão e variedade em relação ao Revit. }\end{array}$ \\
\hline $\begin{array}{l}2.2 \text { Ao modelar o projeto é } \\
\text { necessário definir com } \\
\text { precisão os atributos dos } \\
\text { elementos construtivos do } \\
\text { edifício? }\end{array}$ & $\begin{array}{l}\text { Sim. Nos sistemas BIM a modelagem de um objeto requer que todos os } \\
\text { materiais utilizados na construção sejam informados pelo projetista. } \\
\text { Contudo é possível utilizar o estudo de massa no Revit no processo de } \\
\text { criação do projeto. }\end{array}$ & $\begin{array}{l}\text { Não. O Ecotect não representa as propriedades dos elementos } \\
\text { construtivos do edifício. }\end{array}$ \\
\hline $\begin{array}{l}\text { 2.3 Modela propriedades } \\
\text { dimensionais (envolvendo } \\
\text { dimensões e proporções } \\
\text { dos elementos } \\
\text { construtivos) e possibilita } \\
\text { as relações entre os } \\
\text { componentes e seus } \\
\text { respectivos vínculos e } \\
\text { hierarquias? }\end{array}$ & $\begin{array}{l}\text { Sim. Ao modelar os elementos construtivos (como paredes, lajes, pisos } \\
\text { e etc) é necessário inserir dados referentes ao material e espessura de } \\
\text { cada elemento da construção que compõe o todo. Como exemplo } \\
\text { podemos citar que para a construção de paredes foi incluída na barra de } \\
\text { propriedades da família de paredes os elementos que compõem a } \\
\text { construção (acabamento interno, acabamento externo, emboço, reboco } \\
\text { e núcleo da parede / estrutura principal) com suas devidas espessuras. } \\
\text { Cada elemento possui relações vinculadas entre eles. }\end{array}$ & $\begin{array}{l}\text { Não. O Ecotect trabalha apenas com volumetrias que representam os } \\
\text { elementos construtivos. }\end{array}$ \\
\hline \multicolumn{3}{|c|}{ 3. Definir a localização geográfica do projeto } \\
\hline $\begin{array}{l}\text { 3.1 Disponibiliza de } \\
\text { ferramentas para definir a } \\
\text { localização geográfica do } \\
\text { projeto? }\end{array}$ & $\begin{array}{l}\text { Sim. O Revit disponibiliza ferramentas para definir a localização } \\
\text { geográfica do projeto com funções muito similares ao Ecotect. }\end{array}$ & $\begin{array}{l}\text { Sim. O Ecotect disponibiliza ferramentas para inserir a localização } \\
\text { geográfica do projeto. }\end{array}$ \\
\hline $\begin{array}{l}3.2 \text { Possibilita a } \\
\text { localização integrada ao } \\
\text { "Google Maps"? }\end{array}$ & $\begin{array}{l}\text { Sim. O Revit possui em sua interface mapa interativo que funciona por } \\
\text { meio do "Google Maps". Para execução desta função é necessário estar } \\
\text { conectado a Internet. }\end{array}$ & $\begin{array}{l}\text { Sim. O Ecotect possui em sua interface mapa interativo que funciona } \\
\text { por meio do "Google Maps". Para execução desta função é necessário } \\
\text { estar conectado a Internet. }\end{array}$ \\
\hline
\end{tabular}




\begin{tabular}{|c|c|c|}
\hline $\begin{array}{l}3.3 \text { Possui um banco de } \\
\text { dados próprio para a } \\
\text { localização do projeto? }\end{array}$ & $\begin{array}{l}\text { Sim. Possui um banco de dados próprio conforme a lista de cidades } \\
\text { preestabelecidas. A localização do projeto é importante para determinar } \\
\text { o clima local para realizar a simulação ambiental. }\end{array}$ & $\begin{array}{l}\text { Sim. Possui um banco de dados próprio conforme a lista cidades } \\
\text { preestabelecidas. A localização do projeto é importante para determinar } \\
\text { o clima local para simulação ambiental. }\end{array}$ \\
\hline \multicolumn{3}{|c|}{ 4. Definir o norte de projeto } \\
\hline $\begin{array}{l}\text { 4.1 Disponibiliza de } \\
\text { ferramentas para inserir o } \\
\text { norte do projeto? }\end{array}$ & $\begin{array}{l}\text { Sim. Disponibiliza ferramentas para inserir o norte do projeto. } \\
\text { Contudo no Revit existem dois tipos de norte: o norte verdadeiro } \\
\text { ("true north") e o norte de projeto ("project north"). } \\
\text { O norte de projeto como padrão do Revit encontra-se a } 90 \text { graus. No } \\
\text { caso do edifício do TSE o norte encontra-se a } 107 \text { graus. Informa-se } \\
\text { que ao selecionar o norte verdadeiro o projeto é rotacionado conforme } \\
\text { ilustrado na figura } 46 \text { desta Dissertação. Outra questão importante, é } \\
\text { que para as simulações da LN é necessário selecionar o norte } \\
\text { verdadeiro. }\end{array}$ & $\begin{array}{l}\text { Sim. Possui ferramentas para inserir o norte do projeto. No Ecotect } \\
\text { não é preciso inserir dois nortes no projeto pois ao modificar o norte } \\
\text { conforme realidade, o projeto não é rotacionado. Isto ocorre porque o } \\
\text { que se rotaciona é o trajeto solar. }\end{array}$ \\
\hline
\end{tabular}

\begin{tabular}{|c|c|c|c|c|}
\hline & \multicolumn{2}{|l|}{ REVIT sem plug-in } & \multicolumn{2}{|c|}{ ECOTECT } \\
\hline \multicolumn{5}{|c|}{ 5. Estudo do caminho do sol e sombra } \\
\hline $\begin{array}{l}\text { 5.1 Em que data e horário } \\
\text { é possível executar a } \\
\text { simulação? }\end{array}$ & \multicolumn{2}{|c|}{$\begin{array}{l}\text { É possível fazer a simulação da iluminância em qualquer data do ano e } \\
\text { horário do dia. Também viabiliza gerar em uma única simulação o } \\
\text { caminho do sol e sombra de um dia ou vários dias do ano. }\end{array}$} & \multicolumn{2}{|c|}{$\begin{array}{l}\text { É possível fazer a simulação da iluminância em qualquer data do ano e } \\
\text { horário do dia. Também viabiliza gerar em uma única simulação o } \\
\text { caminho do sol e sombra de um dia ou vários dias do ano. }\end{array}$} \\
\hline $\begin{array}{l}5.2 \text { Viabiliza a execução } \\
\text { de vídeos para o estudo de } \\
\text { caminho solar e sombras? }\end{array}$ & \multicolumn{2}{|c|}{$\begin{array}{l}\text { Sim. O Revit possui ferramentas para criação de vídeos do caminho do } \\
\text { sol e sombras no período de um dia ou vários dias. }\end{array}$} & \multicolumn{2}{|c|}{$\begin{array}{l}\text { Sim. O Ecotect possui ferramentas para criação de vídeos do caminho } \\
\text { do sol e sombras no período de um dia ou vários dias. }\end{array}$} \\
\hline $\begin{array}{l}5.3 \text { Onde é gerada a } \\
\text { simulação. }\end{array}$ & \multicolumn{2}{|c|}{$\begin{array}{l}\text { A simulação foi gerada para o projeto do TSE em menos de três } \\
\text { minutos no computador local. }\end{array}$} & \multicolumn{2}{|l|}{ No computador local. } \\
\hline \multicolumn{5}{|c|}{ 6. Simulação da iluminância } \\
\hline & REVIT sem plug-in & \multicolumn{2}{|c|}{$\begin{array}{l}\text { REVIT com plug-in } \\
\text { (Autodesk Insight } 360 \text { ) }\end{array}$} & ECOTECT \\
\hline $\begin{array}{l}\text { 6.1 Possui ferramentas } \\
\text { para fazer simulação da } \\
\text { iluminância? }\end{array}$ & $\begin{array}{l}\text { Sim. Possui ferramentas para fazer simulação da } \\
\text { iluminância. }\end{array}$ & \multicolumn{2}{|c|}{$\begin{array}{l}\text { Sim. Possui de ferramentas para fazer simulação } \\
\text { de iluminância. }\end{array}$} & $\begin{array}{l}\text { Sim. Possui de ferramentas para fazer } \\
\text { simulação da iluminância. }\end{array}$ \\
\hline $\begin{array}{l}\text { 6.2 Em que data é possível } \\
\text { executar a simulação de }\end{array}$ & $\begin{array}{l}\text { É possível fazer a simulação de iluminância em } \\
\text { qualquer data do ano e horário do dia. Contudo o }\end{array}$ & \multicolumn{2}{|c|}{$\begin{array}{l}\text { É possível fazer a simulação da iluminância em } \\
\text { qualquer data do ano e horário do dia. }\end{array}$} & $\begin{array}{l}\text { É possível fazer a simulação da } \\
\text { iluminância em qualquer data do ano e }\end{array}$ \\
\hline
\end{tabular}




\begin{tabular}{|c|c|c|c|}
\hline iluminância? & $\begin{array}{l}\text { software gera a simulação em apenas uma data e } \\
\text { horário de cada vez. }\end{array}$ & & horário do dia. \\
\hline $\begin{array}{l}\text { 6.3 É possível fazer } \\
\text { simulação de iluminância } \\
\text { de todos os pavimentos de } \\
\text { uma única vez? }\end{array}$ & $\begin{array}{l}\text { Sim. Para a simulação da iluminância no Revit é } \\
\text { necessário criar as vistas para cada pavimento e } \\
\text { gerar a simulação dos pavimentos desejados para } \\
\text { análise. }\end{array}$ & $\begin{array}{l}\text { Sim. Contudo para visualização dos resultados é } \\
\text { necessário salvar as vistas de cada pavimento e } \\
\text { depois selecionar os comandos para visualizar os } \\
\text { resultados no Revit. }\end{array}$ & $\begin{array}{l}\text { Sim. A simulação da iluminância no } \\
\text { Ecotect pode gerar resultados para } \\
\text { todos os pavimentos do projeto. }\end{array}$ \\
\hline $\begin{array}{l}\text { 6.4 O software permite } \\
\text { gerar gráfico de cores } \\
\text { "false color"? }\end{array}$ & $\begin{array}{l}\text { Sim. O resultado da simulação de iluminância é } \\
\text { gerado por meio do gráfico de cores onde os } \\
\text { valores de lux estão indicados na legenda. }\end{array}$ & $\begin{array}{l}\text { Sim. O resultado da simulação da iluminância é } \\
\text { apresentado por meio do gráfico de cores onde os } \\
\text { valores de lux estão indicados na legenda. }\end{array}$ & $\begin{array}{l}\text { Sim. O resultado da simulação da } \\
\text { iluminância é gerado por meio do } \\
\text { gráfico de cores onde os valores de lux } \\
\text { estão indicados na legenda. }\end{array}$ \\
\hline $\begin{array}{l}6.5 \text { Viabiliza a edição da } \\
\text { legenda das cores e dos } \\
\text { valores de lux? }\end{array}$ & $\begin{array}{l}\text { Não. Sem o "plug-in" não é possível editar as } \\
\text { cores da legenda apenas valores máximos e } \\
\text { mínimos de lux. }\end{array}$ & $\begin{array}{l}\text { Sim. As cores e valores da legenda podem ser } \\
\text { editados conforme o interesse do usuário. Vale } \\
\text { informar que os valores, máximo e mínimo de lux } \\
\text { não podem ser modificados. }\end{array}$ & $\begin{array}{l}\text { Sim. A legenda pode ser editada } \\
\text { conforme interesse do usuário. }\end{array}$ \\
\hline $\begin{array}{l}\text { 6.6 Permite gerar vistas } \\
\text { internas para simulação? }\end{array}$ & $\begin{array}{l}\text { Sim, é possível gerar vistas internas no Revit para } \\
\text { simulação da iluminância. }\end{array}$ & $\begin{array}{l}\text { Sim, é possível gerar vistas internas no Revit para } \\
\text { simulação da iluminância, contudo esta tarefa é } \\
\text { posterior à simulação sendo necessário executar } \\
\text { novos comandos para sua visualização. Esta tarefa } \\
\text { no Revit com "plug-in" demanda mais tempo em } \\
\text { relação ao Revit sem "plug-in". }\end{array}$ & Sim. \\
\hline $\begin{array}{l}6.7 \text { Onde é gerada a } \\
\text { simulação? }\end{array}$ & $\begin{array}{l}\text { A simulação é gerada na nuvem e não no } \\
\text { computador local. Isto permite continuar usando o } \\
\text { computador enquanto a simulação está sendo } \\
\text { realizada. }\end{array}$ & $\begin{array}{l}\text { A simulação é gerada na nuvem e não no } \\
\text { computador local. Permite continuar usando o } \\
\text { computador enquanto a simulação está sendo } \\
\text { realizada. }\end{array}$ & $\begin{array}{l}\text { A simulação é gerada no computador } \\
\text { local. }\end{array}$ \\
\hline $\begin{array}{l}6.8 \text { Onde os resultados são } \\
\text { visualizados? }\end{array}$ & $\begin{array}{l}\text { Os resultados são visualizados no site da } \\
\text { "Autodesk A360 Rendering”. Neste site é } \\
\text { possível alterar os dados (data, horário, tipo de } \\
\text { céu) da simulação para gerar novos estudos. }\end{array}$ & $\begin{array}{l}\text { São visualizados no site da “Autodesk A360 } \\
\text { Rendering” e no próprio Revit. }\end{array}$ & $\begin{array}{l}\text { Os resultados são visualizados no } \\
\text { próprio software. }\end{array}$ \\
\hline $\begin{array}{l}\text { 6.9 Os valores de } \\
\text { Irradiância Direta Normal } \\
\text { - DNI são informados } \\
\text { pelo software? }\end{array}$ & $\begin{array}{l}\text { Não. O Valor do DNI deve ser inserido } \\
\text { manualmente pelo usuário de acordo com } \\
\text { localização do projeto. }\end{array}$ & $\begin{array}{l}\text { Sim. Os valores da DNI podem ser inseridos } \\
\text { manualmente. Por outro lado, se selecionar a } \\
\text { opção "use weather data" que informará o valor } \\
\text { de DNI conforme a localização do projeto. }\end{array}$ & $\begin{array}{l}\text { Sim. Mas não possui a opção de inserir } \\
\text { o valor de DNI manualmente. }\end{array}$ \\
\hline $\begin{array}{l}6.10 \text { Os valores de } \\
\text { Irradiância Difusa } \\
\text { Horizontal - DHI são } \\
\text { informados pelo }\end{array}$ & $\begin{array}{l}\text { Não. O Valor do DHI deve ser inserido } \\
\text { manualmente pelo usuário de acordo com } \\
\text { localização do projeto. }\end{array}$ & $\begin{array}{l}\text { Sim. O valor da DHI pode ser inserido } \\
\text { manualmente ou ao selecionar a opção "use } \\
\text { weather data" é informado o valor de DHI } \\
\text { conforme localização do projeto. }\end{array}$ & $\begin{array}{l}\text { Sim. Mas não possui a opção de inserir } \\
\text { o valor de DHI manualmente. }\end{array}$ \\
\hline
\end{tabular}




\begin{tabular}{|c|c|c|c|}
\hline \multicolumn{4}{|l|}{ software? } \\
\hline $\begin{array}{l}6.11 \text { O software foi } \\
\text { validado? }\end{array}$ & $\begin{array}{l}\text { Foi validado por empresas especializadas no } \\
\text { cálculo da LN e comparado ao Radiance, um } \\
\text { software "standard" na indústria de simulação } \\
\text { lumínica. E também foi validado por meio de } \\
\text { medição "in loco" do espaço analisado. (Fonte: } \\
\text { http://sustainabilityworkshop.autodesk.com/buildi } \\
\text { ngs/revit-illuminance-simulations Acessado em: } \\
01 / 06 / 2016)\end{array}$ & $\begin{array}{l}\text { Foi validado por empresas especializadas no } \\
\text { cálculo de LN e comparado ao Radiance, um } \\
\text { software "standard" na indústria de simulação } \\
\text { lumínica. E também foi validado por meio de } \\
\text { medição "in loco" do espaço analisado. (Fonte: } \\
\text { http://sustainabilityworkshop.autodesk.com/buildi } \\
\text { ngs/revit-illuminance-simulations Acessado em: } \\
01 / 06 / 2016 \text { ) }\end{array}$ & $\begin{array}{l}\text { Sim. Validado e aceito no meio } \\
\text { científico pela "CIBSE TM33 (2006) } \\
\text { Tests for Software Verification and } \\
\text { Accreditation". } \\
\text { (Fonte: } \\
\text { https://knowledge.autodesk.com/suppo } \\
\text { rt/ecotect- } \\
\text { analysis/troubleshooting/caas/sfdcarticl } \\
\text { es/sfdcarticles/Validation-of-Ecotect- } \\
\text { Analysis-results.html. Acessado em: } \\
03 / 05 / 2016)\end{array}$ \\
\hline \multicolumn{4}{|c|}{ 7. Simulação do Fator de Luz do Dia- FLD } \\
\hline & REVIT sem plug-in & $\begin{array}{l}\text { REVIT com plug-in } \\
\text { (Autodesk Insight } 360 \text { ) }\end{array}$ & ECOTECT \\
\hline $\begin{array}{l}\text { 7.1 Possui ferramentas } \\
\text { para simulação do Fator } \\
\text { de Luz do Dia? }\end{array}$ & $\begin{array}{l}\text { Sim. Possui ferramentas para simulação do Fator } \\
\text { de Luz do Dia. }\end{array}$ & $\begin{array}{l}\text { Sim. Possui ferramentas para simulação do Fator } \\
\text { de Luz do Dia. }\end{array}$ & $\begin{array}{l}\text { Sim. Possui } \quad \text { ferramentas para } \\
\text { simulação do Fator de Luz do Dia. }\end{array}$ \\
\hline $\begin{array}{l}\text { 7.2 Qual a data é possível } \\
\text { executar a simulação? }\end{array}$ & $\begin{array}{l}\text { É possível fazer a simulação do FLD em qualquer } \\
\text { data do ano e horário do dia. Contudo o software } \\
\text { permite fazer a simulação de apenas uma data e } \\
\text { horário de cada vez. }\end{array}$ & $\begin{array}{l}\text { É possível fazer a simulação do FLD em qualquer } \\
\text { data do ano e horário do dia. }\end{array}$ & $\begin{array}{l}\text { É possível fazer a simulação do FLD } \\
\text { em qualquer data do ano e horário do } \\
\text { dia. }\end{array}$ \\
\hline $\begin{array}{l}7.3 \text { É possível fazer } \\
\text { simulação de todos os } \\
\text { pavimentos de uma única } \\
\text { vez? }\end{array}$ & $\begin{array}{l}\text { Sim. Para a simulação da iluminância no Revit é } \\
\text { necessário criar as vistas para cada pavimento e } \\
\text { gerar a simulação dos pavimentos desejados para } \\
\text { análise. }\end{array}$ & $\begin{array}{l}\text { Sim. Contudo para visualização dos resultados é } \\
\text { necessário salvar as vistas de cada pavimento e } \\
\text { depois selecionar os comandos para visualizar os } \\
\text { resultados no Revit. }\end{array}$ & $\begin{array}{l}\text { Sim. A simulação do FLD no Ecotect } \\
\text { pode gerar resultados para todos os } \\
\text { pavimentos do projeto. }\end{array}$ \\
\hline $\begin{array}{l}\text { 7.4 O software permite } \\
\text { gerar gráfico de cores } \\
\text { "false color"? }\end{array}$ & $\begin{array}{l}\text { Sim. O resultado da simulação do FLD é gerado } \\
\text { por meio de gráfico de cores onde os valores } \\
\text { estão indicados na legenda. }\end{array}$ & $\begin{array}{l}\text { Sim. O resultado da simulação do FLD é gerado } \\
\text { por meio do gráfico de cores onde os valores } \\
\text { estão indicados na legenda. }\end{array}$ & $\begin{array}{l}\text { Sim. O resultado da simulação do FLD } \\
\text { é gerado por meio do gráfico de cores } \\
\text { onde os valores estão indicados na } \\
\text { legenda. }\end{array}$ \\
\hline $\begin{array}{l}7.5 \text { Viabiliza a edição de } \\
\text { legenda? }\end{array}$ & $\begin{array}{l}\text { Não. Sem o plug-in não é possível editar as cores } \\
\text { de legenda, mas apenas valores máximos e } \\
\text { mínimos. }\end{array}$ & $\begin{array}{l}\text { Sim. As cores e valores da legenda podem ser } \\
\text { editados conforme interesse do usuário. Vale } \\
\text { informar que os valores máximo e mínimo não } \\
\text { podem ser modificados. }\end{array}$ & $\begin{array}{l}\text { Sim. A legenda pode ser editada } \\
\text { conforme interesse do usuário. }\end{array}$ \\
\hline 7.6 Permite gerar vistas & Sim, é possível gerar vistas internas no Revit para & Sim, é possível gerar vistas internas no Revit para & Sim. \\
\hline
\end{tabular}




\begin{tabular}{|c|c|c|c|}
\hline internas para simulação? & simulação do FLD. & $\begin{array}{l}\text { simulação do FLD, contudo esta tarefa é posterior } \\
\text { à simulação sendo necessário executar novos } \\
\text { comandos para sua visualização. Esta tarefa no } \\
\text { Revit com "plug-in" demanda mais tempo em } \\
\text { relação ao Revit sem "plug-in". }\end{array}$ & \\
\hline $\begin{array}{l}7.7 \text { Onde é gerada a } \\
\text { simulação? }\end{array}$ & $\begin{array}{l}\text { A simulação é gerada na nuvem e não no } \\
\text { computador local. Permite assim continuar } \\
\text { usando o computador enquanto a simulação está } \\
\text { sendo realizada. }\end{array}$ & $\begin{array}{l}\text { A simulação é gerada na nuvem e não no } \\
\text { computador local. Viabiliza continuar usando o } \\
\text { computador enquanto a simulação está sendo } \\
\text { realizada. }\end{array}$ & $\begin{array}{l}\text { A simulação é gerada no computador } \\
\text { local. }\end{array}$ \\
\hline $\begin{array}{l}7.8 \text { Onde os resultados são } \\
\text { visualizados? }\end{array}$ & $\begin{array}{l}\text { Os resultados são visualizados no site da } \\
\text { "Autodesk A360 Rendering". No site da } \\
\text { "Autodesk A360 Rendering" é possível alterar os } \\
\text { dados (data, horário, tipo de céu) da simulação } \\
\text { para gerar novos estudos. }\end{array}$ & $\begin{array}{l}\text { Os resultados são visualizados no site da } \\
\text { "Autodesk A360 Rendering" e no próprio Revit. }\end{array}$ & $\begin{array}{l}\text { Os resultados são visualizados no } \\
\text { próprio software. }\end{array}$ \\
\hline $\begin{array}{l}\text { 7.9 Os valores de } \\
\text { Irradiância Direta Normal } \\
\text { - DNI são informados pelo } \\
\text { "software"? }\end{array}$ & $\begin{array}{l}\text { Não. Ao selecionar a opção "Daylight Factor } \\
\text { Sky" não é possível alterar os valores de DNI. }\end{array}$ & $\begin{array}{l}\text { Sim. O valor da DNI pode ser inserido } \\
\text { manualmente ou ao selecionar a opção "use } \\
\text { weather data" é informado o valor de DNI } \\
\text { conforme localização do projeto. }\end{array}$ & $\begin{array}{l}\text { Sim. Não possui a opção de inserir o } \\
\text { valor de DNI manualmente. }\end{array}$ \\
\hline $\begin{array}{l}\text { 7.10 Os valores de } \\
\text { Irradiância Difusa } \\
\text { Horizontal - DHI são } \\
\text { informados pelo software? }\end{array}$ & $\begin{array}{l}\text { Não. Ao selecionar a opção "Daylight Factor } \\
\text { Sky" não é possível alterar os valores de DHI. }\end{array}$ & $\begin{array}{l}\text { Sim. O valor da DHI pode ser inserido } \\
\text { manualmente ou ao selecionar a opção "use } \\
\text { weather data" é informado o valor de DHI } \\
\text { conforme localização do projeto. }\end{array}$ & $\begin{array}{l}\text { Sim. Não possui a opção de inserir o } \\
\text { valor de DHI manualmente. }\end{array}$ \\
\hline $\begin{array}{l}7.11 \text { O software foi } \\
\text { validado? }\end{array}$ & $\begin{array}{l}\text { Foi validado por empresas especializadas no } \\
\text { calculo da LN e comparado ao Radiance, um } \\
\text { software "standard" na indústria de simulação } \\
\text { lumínica. E também foi validado por meio de } \\
\text { medição "in loco" do espaço analisado. (Fonte: } \\
\text { http://sustainabilityworkshop.autodesk.com/buildi } \\
\underline{\text { ngs/revit-illuminance-simulations }} \text { Acessado em: } \\
01 / 06 / 2016)\end{array}$ & $\begin{array}{l}\text { Foi validado por empresas especializadas no } \\
\text { cálculo da LN e comparado ao Radiance, um } \\
\text { software "standard" na indústria de simulação } \\
\text { lumínica. E também foi validado por meio de } \\
\text { medição "in loco" do espaço analisado. (Fonte: } \\
\text { http://sustainabilityworkshop.autodesk.com/buildi } \\
\text { ngs/revit-illuminance-simulations Acessado em: } \\
01 / 06 / 2016)\end{array}$ & $\begin{array}{l}\text { Sim. Validado e aceito no meio } \\
\text { científico pela "CIBSE TM33 (2006) } \\
\text { Tests for Software Verification and } \\
\text { Accreditation". } \\
\text { (Fonte: } \\
\text { https://knowledge.autodesk.com/suppo } \\
\text { rt/ecotect- } \\
\text { analysis/troubleshooting/caas/sfdcarticl } \\
\text { es/sfdcarticles/Validation-of-Ecotect- } \\
\text { Analysis-results.html. Acessado em: } \\
03 / 05 / 2016)\end{array}$ \\
\hline
\end{tabular}




\begin{tabular}{|c|c|c|c|}
\hline & REVIT sem plug-in & $\begin{array}{l}\text { REVIT com plug-in } \\
\text { (Autodesk Insight } 360 \text { ) }\end{array}$ & ECOTECT \\
\hline $\begin{array}{l}\text { 8.1 Possui ferramentas } \\
\text { para a simulação da } \\
\text { luminância? }\end{array}$ & $\begin{array}{l}\text { O Revit não possui ferramentas para a simulação } \\
\text { da luminância. }\end{array}$ & $\begin{array}{l}\text { O Revit não possui ferramentas para a simulação } \\
\text { da luminancia. }\end{array}$ & $\begin{array}{l}\text { O Ecotect possui ferramentas para } \\
\text { fazer simulação da luminância. }\end{array}$ \\
\hline
\end{tabular}

Tabela 2: QUADRO GERAL DE RESULTADOS DA AVALIAÇÃO DO REVIT UTILIZANDO COMO BENCHMARK O ECOTECT.

Fonte: autoria nossa 


\subsection{CONCLUSÃO}

Os softwares para a simulação da LN estão em constantes modificações e aprimoramento. Em março de 2015 o Ecotect deixou de ser comercializado sendo inserido no mercado pela Autodesk o plug-in LA/R para a simulação da LN no Revit. Posteriormente, em primeiro de julho de 2016, as funcionalidades dos plug-in LA/R e "Energy Analysis" foram atualizadas e integradas ao plug-in "Insight 360" da Autodesk . Contudo, sugere-se como recomendação, que se utilize um período de adaptação à nova tecnologia antes da retirada desta ferramenta do mercado, visto que muitas vezes a documentação do programa não está totalmente completa além de demandar tempo para aprendizagem de novas ferramentas.

Verificou-se por meio do experimento que o software Revit, que é o sistema BIM escolhido para esta pesquisa, pode contribuir como ferramenta de estudo e avaliação da luz natural nos projetos de arquitetura sem a necessidade de exportação dos mesmos para um simulador ambiental individual. A integração entre as funcionalidades do simulador ambiental individual (Ecotect) e os sistemas BIM (Revit) é uma realidade, apesar de algumas peculiaridades divergentes. Esta integração é uma ferramenta promissora para utilização da mesma no início do processo de projetação. Desta forma permitirá estudos e compreensão das variáveis referentes à LN que interferem diretamente no conforto visual e consumo energético do projeto.

Os parâmetros referentes à LN que foram factíveis de simulação no Revit (por meio do experimento) sem a necessidade de exportar o projeto para outro software de simulação ambiental individual e sem a instalação do plug-in (Autodesk Insight 360) são: estudo do caminho do sol e sombras, simulação da iluminância, e fator de luz natural.

Tomado como referência as simulações disponíveis no Ecotect em relação ao Revit para simulação da LN, conclui-se que, em relação ao estudo do caminho do sol e projeção das sombras, as funcionalidades são muito semelhantes, não havendo nenhum prejuízo de compreensão ao realizar esta simulação no Revit. Ambos os softwares disponibilizam estas simulações a qualquer horário do dia e mês do ano. Esta simulação é realizada de forma rápida em menos de três minutos e permite também a criação de vídeos do caminho solar em um ou vários dias. A simulação integrada permitiu verificar no experimento que a fachada norte do edifício do TSE está mais exposta aos raios solares diretos durante o ano e principalmente no período da tarde entre doze e dezessete horas. Isto pode ser um dos motivos pelo quais no edifício do TSE possui brises apenas na fachada norte. 
Sobre a simulação da iluminância realizada no Revit, sem a instalação do plugin, informa-se que é necessário salvar as vistas nas quais será realizada o cálculo da iluminância. Para fazer a simulação de todos os pavimentos do projeto é necessário salvar a vista de cada um dos pavimentos e gerar as simulações. Isto é uma limitação em relação ao que era possível fazer no Ecotect. Neste não era necessário salvar as vistas do projeto. Outra questão importante é que no Revit é gerada a simulação para apenas uma determinada data e hora, portanto para uma análise detalhada do edifício é necessário gerar várias simulações para cada data e hora desejada. O Ecotect disponibilizava recurso para simulação da iluminância durante o ano todo em diferentes horas do dia em uma única simulação.

Este procedimento de simulação da iluminância com o plug-in "Autodesk Insight 360" foi realizado no edifício do TSE em todos os pavimentos conforme detalhado item 6.5.8, e demorou aproximadamente duas horas. Vale acrescentar que o Revit com plug-in disponibiliza ferramentas para simulação da iluminância de todos os pavimentos em uma única simulação, contudo para visualização dos resultados de cada pavimento no software é necessário selecionar a vista que se deseja visualizar o resultado na barra de propriedades por meio dos comandos: "analyze" > " lighting". Esta Simulação da iluminância demorou mais tempo que a simulação sem o "plug-in Insight 360”. Observa-se que, de qualquer forma, isto representa uma integração dos recursos de simulação ainda parcial. A necessidade de se recorrer a instalação de um plug-in representa um elemento que pode desestimular o uso da simulação pelo usuário iniciante.

Sobre a simulação da luminância constatou-se que a mesma ainda não está disponível no Revit 2016 e nem mesmo por meio do plug-in. Isto constitui uma limitação em relação ao que era possível fazer no Ecotect que disponibilizava esta simulação em sua interface. Visto que cada superfície possui diferente capacidade de reflexão dos raios incidentes, uma certa iluminância pode gerar diferentes luminâncias. O cálculo da luminância é um importante parâmetro que pode indicar níveis de desconforto e ofuscamento visual.

Pode-se citar como um avanço do Revit em relação ao padrão estabelecido pelo Ecotect devido ao fato de que a simulação é gerada na nuvem de forma mais rápida o que permite continuar utilizando o computador para outras tarefas, enquanto a simulação está sendo gerada. O tempo gasto nas simulações depende da complexidade do modelo. 
A simulação da LN é totalmente dependente dos dados de entrada referentes a modelagem de projeto, especificações dos materiais e fonte de luz. A simulação da LN deve ser inserida no inicio do processo de projetação. Por meio das simulações da LN geradas no experimento do edifício do TSE verificou-se excesso de iluminância em áreas próximas a fachada de vidro, o que ocasionou necessidade de instalação de persianas em todas as fachadas para evitar a LN direta e ofuscamentos no ambiente de trabalho o que por outro lado escurece o ambiente, exige a utilização de luz artificial durante o dia e impede a apreciação da vista externa. Já em outros ambientes do TSE, como é o caso dos corredores, também é necessário recorrer a luz artificial visto a falta de disponibilidade de LN. Portando existe uma distribuição da LN inadequada no projeto.

Caso tivesse sido realizadas simulações da LN no processo de projetação do TSE as informações geradas de que o ambiente proposto ficaria exposto ao ofuscamento poderia indicar a necessidade de mudanças no projeto como redirecionar o posicionamento da edificação, ou redefinir o revestimento da fachada com materiais com maior refletância ou ainda o reposicionamento das aberturas. A simulação da LN no processo de projetação nos sistemas BIM, representa uma ferramenta importante e promissora para viabilizar construções sustentáveis, com menor gasto energético e maior conforto aos usuários.

A criação de um software que viabiliza a coordenação entre diferentes disciplinas é algo muito vantajoso e desejado por muitos projetistas e pesquisadores que procuram ferramentas que viabilizem a realização de um número cada vez maior de operações diversificadas em um mesmo ambiente computacional. Por meio da simulação ambiental diretamente no Revit evita-se a tarefa de exportação do projeto para um simulador ambiental individual que muitas vezes não permite a interoperabilidade integral, e requer o retrabalho de reconfigurar uma série de variáveis de projeto tais como as especificações dos materiais e volumetrias e aberturas não reconhecidas pelo software de simulação ambiental.

Acredita-se que, como consequência do conhecimento adquirido neste experimento e divulgação das vantagens provenientes dos resultados encontrados, o(a) arquiteto(a) poderá ser estimulado(a) a incluir a avaliação da luz natural no processo de concepção dos espaços edificados diretamente nos sistemas BIM. O resultado mais importante obtido neste estudo é a verificação de que já existem recursos significativos que permitem a simulação ambiental integrada ao processo de projetação. A título de desenvolvimento futuro, poder-se-ia elaborar um manual para o usuário iniciante 
contendo um conjunto de orientações que facilitem a utilização dos recursos de avaliação do conforto lumínico.

Contudo, a hipótese apresentada nesta dissertação consistia na seguinte pressuposição: os sistemas BIM podem contribuir como ferramenta de estudo e avaliação da luz natural no processo de projetação arquitetônica sem a necessidade de exportação do projeto para um simulador ambiental individual. É importante salientar, entretanto, que verificamos que esta integração ainda não é total porque alguns recursos relatados acima e na tabela 2, ainda não estão presentes no Revit. A ausência destes recursos poderia levar a necessidade de utilizar softwares externos ao Revit. 


\section{REFERÊNCIAS BIBLIOGRÁFICAS}

ANDRADE, Ludmila Santos. A Contribuição dos Sistemas BIM para o Planejamento Orçamentário das Obras Públicas: Estudo de Caso do Auditório e da Biblioteca de Planaltina. Dissertação de Mestrado em Arquitetura, FAU/ UNB; 2012 .

ANDRADE, Liza Maria Souza. O conceito de Cidades-Jardins: uma adaptação para as cidades sustentáveis. Disponível em:

< http://www.vitruvius.com.br/arquitextos/arq042/arq042_02.asp.> Acessado em outubro 2008.

ANDRADE, Max Lira Veras X.; RUSCHEL, Regina Coeli. Interoperabilidade de Aplicativos BIM Usados em Arquitetura por Meio do Formato IFC. Artigo Gestão \& Tecnologia de Projetos [ISSN 19811543], Vol. 4, Novembro 2009.

AMORIM, Claudia Naves David. Iluminação Natural e Eficiência Energética Parte I: Estratégias de Projeto para uma Arquitetura Sustentável. Brasília, Nov. 2002. Disponível em < http://www.rodrigomindlinloeb.arq.br/eficiencia_energetica.pdf $>$. Acesso em 04 de nov. 2014.

AMORIM, Claudia Naves David. A Avaliação Ambiental Integrada e Simulação Computacional: interfaces, limitações e potencialidades. Artigo FAU/UNB; fevereiro 2006.

BRAGA, Darja Kos. Arquitetura Residencial duas Superquadras do Plano Piloto de Brasília: aspectos do conforto térmico. Dissertação de Mestrado em ArquiteturaFAU/ UNB; 2005.

BUCHMANN, Armando José. Lúcio Costa: O Inventor da cidade de Brasília: centenário de nascimento. Brasília: Thesaurus, 2002.

CARFAN, Ana Claudia; GALVANI, Emerson e NERY, Jonas Teixeira. O Estudo do Sombreamento no Conforto Térmico Estudo de Caso: Cidade de São Paulo. Artigo Universidade de Coimbra ;maio 2010 .

CARFAN ,Ana Claudia; GALVANI, Emerson ; NERY, Jonas Teixeira.Calibração do Modelo ENVI - met: Estudo do Clima Urbano de Ourinhos, SP. Disponivel em: http://www.geo.ufv.br/simposio/simposio/trabalhos/trabalhos_completos/eixo8/002.pdf. acessado em fevereiro de 2013.

CARPINTERO, Antonio Carlos Cabral. Brasília: Prática e Teoria Urbanística no Brasil 1956-1998. Tese de Doutorado em Arquitetura Faculdade de Arquitetura e Urbanismo da Universidade de São Paulo. USP, São Paulo, 1998.

CORBELlA, Oscar e YANNAS, Simos . Em busca de uma Arquitetura Sustentável para os trópicos- conforto ambiental. Rio de Janeiro: Revan. 2003.

COSTA, Lúcio. Considerações Sobre Arte Contemporânea (1940). In: Lúcio Costa, Registro de uma vivência. São Paulo: Empresa das Artes, 1995, p. 245-258. 
CREMONINI, Lorenzo. Luce Natureale, Luce Artificiale. Firenza, Itália: Editora Alínea, 1992 (Tradução e adaptação Cláudia Naves Amorim)

CHRISTAKOU, Evangelos D., Simulação Computacional da Luz Natural Aplicada ao Projeto de Arquitetura. Dissertação de Mestrado em Arquitetura, FAU/ UNB; 2004

EASTMAN, Chuck. et al. Bim Handbook- A Guide to Building Information Modeling. John Wiley\& Sons, New Jersey, 2008.

EASTMAN, Chuck .et al. Bim Handbook- A Guide to Building Information Modeling. John Wiley\& Sons, New Jersey, 2011.

GOUVÊA, Luiz Alberto. Biocidade: conceitos e critérios para um desenho ambiental urbano, em localidades de clima tropical de planalto. São Paulo: Nobel, 2002 .

HOPKINSON, R.G; PETHERBRIDGE, P. ; LONGMORE, J. Iluminação Natural. Londres: William Heinemann Ltd , 1966 (Tradução António S. Lobato de Faria)

RIBEIRO, Júlio Tollendal Gomes; SILVA, Neander Furtado; LIMA, Ecilamar Maciel; "Building Information Modeling" como instrumento de projetos aeroportuários. Artigo Universidade de Brasília; SIGraDi 2009 sp.

LAMBERTS, Roberto; DUTRA, Luciano; PEREIRA, Fernando O.R. Eficiência Energética na Arquitetura. São Paulo: PW, 1997.

LEITÃO, Francisco (organizador) et al. Brasília 19602010 Passado, Presente e Futuro. Secretaria de Estado de Desenvolvimento Urbano e Meio Ambiente, Brasília, 2009.

MINETTO, Ciliane f.; Um Estudo Sobre Curvas NURBS. Dissertação de Mestrado em Matemática, Faculdade Federal do Rio Grande do Sul, 2003.

MITCHELL, William J.; MCCULLOUGH, Malcolm. Digital Design Media. John Wiley \& Sons, Inc., Canada, 1994.

MITCHELL, William J. A Lógica da Arquitetura Projeto, Computação e Cognição. Tradução de Gabriela CELANI. Campinas SP: Editora da Unicamp, 2008.

MALARD, Maria Lúcia. Cinco Textos Sobre Arquitetura. Belo Horizonte: Editora UFMG, 2005.

MARCONDES, Mônica Pereira. Soluções Projetuais de Fachadas para Edifícios de Escritórios com Ventilação Natural em São Paulo. Tese de Doutorado, FAU/USP, 2010. 
MARTINS, Paola C.F. A Interoperabilidade entre Sistemas BIM e Simulação Ambiental Computacional: estudo de caso. Dissertação de Mestrado em Arquitetura, FAU/UNB, 2011.

MOTEIRO, Jorge Isaac Perén. Ventilação e Iluminação na Obra de João Filgueiras Lima, Lelé: Estudo dos Hospitais da Rede Sarah Kubitschek Fortaleza e Rio de Janeiro. Dissertação de Mestrado da Escola de Engenharia de São Carlos, Universidade de São Paulo, 2006.

MORAIS, Helen Rachel A., Complexidade e Customização em Massa na Arquitetura Contemporânea. Dissertação de Mestrado em Arquitetura, FAU/UNB; 2010.

NARDELLI, Eduardo S. Arquitetura e Projeto na Era Digital. Arquiteturarevista vol. 3, SP, 2007.

PEREIRA, Miguel Alves. Arquitetura Texto e Contexto: O Discurso de Oscar Niemeyer. Brasília DF: Editora UnB, 1997.

POLONINI, Flávia Biccas da Silva. A Modelagem Paramétrica na Concepção de Formas Curvilíneas da Arquitetura Contemporânea. Dissertação de Mestrado em Arquitetura, Universidade Federal da Bahia; 2014.

RAMIREZ, Miguel C.; SILVA, Neander F.; LIMA, Ecilamar M., Modelagem Tridimen- sional Computacional e Processo de Projetação Arquitetônica: um estudo comparativo. Artigo 2009.

RIBEIRO, Julio Tollendal Gomes. Modelagem de Informação de Edificações Aplicada no Processo de Projeto de Aeroportos. Dissertação de Mestrado em Arquitetura, FAU/UNB, 2010.

RIVERO, Roberto. Arquitetura e Clima: acondicionamento térmico natural. Porto Alegre: D.C. Luzzatto Editores, 1985.

ROBBINS, Edward. Why architects draw. MIT Press, Cambridge, Massachusetts, EUA, 1997.

ROMERO, Marta Adriana Bustos. Arquitetura Bioclimática do Espaço Público. Brasília: Editora UNB, 2001.

ROMERO, Marta A. B. Princípios Bioclimáticos para o Desenho Urbano. $2^{\text {a }}$ ed. São Paulo: Proeditores, 2000.

ROMERO, Marta Adriana Bustos org. Reabilitação Ambiental Sustentável Arquitetônica e Urbanística. 1ª edição. Brasília - DF:FAU-unb, 2009.

SARAMAGO, Rita da Cássia Pereira; BORTOLI, Karen Carrer Ruman. Aplicação de Simulação Computacional na Área de Conforto Ambiental e Eficiência do Curso de Arquitetura e Urbanismo. Artigo 2012. 
SILVA, Ana Paula B. O Desenvolvimento das Mecânicas Não- Euclidianas Durante o Século XIX. Tese de Doutorado, Instituto de Física UNICAMP, 2006.

SILVA, Caio Frederico. Caminhos Bioclimáticos: Desempenho Ambiental de Vias Públicas na Cidade de Teresina-PI. Dissertação de Mestrado em Arquitetura, FAU/UNB, 2009.

SILVA, Neander Furtado e Christakou, Evangelos Dimitrios. Ambientes virtuais na simulação do interior do edifício. Revista Paranoá ,Programa de pós-graduação da FAU/UNB, 2007.

SILVA, Neander F.;BRIDGES, Alan H.; LIMA Ecilamar M.; MORAIS, Helen R. A.; JÚNIOR Félix Alves Silva. A indústria da Construção Civil está Pronta para a Fabricação Digital e a Customização em Massa?Uma Pesquisa obre um Caso Brasileiro. Artigo Sigradi 2009 SP

SUTHERLAND, Ivan Edward. Sketchpad: A man-machine graphical communication system. relatório técnico Universidade de Cambridge, 2003.

KALISPERIS, Loukas. CAD in Education: Penn State University. In ACADIA Quarterly, vol. 15, number 3, 1996.

KERLOW, Isaac Vitor. The Art of 3-D Computer Animation and Imaging. John Wiley \& Sons, Inc., New York, 2000.

KOLAREVIC, Branko, Architecture in the Digital Age - Design and Manufacturing, Taylor \&Francis, New York, 2003.

KOLAREVIC, Branko e MALKAWI, Ali M. Performative Architecture Beyond Instrumentality, Taylor \&Francis, New York, 2005.

KOLAREVIC, Branko e KLINGER, Kevin, Manufacturing Material Effects:

Rethinking Design and Making in Architecture, Taylor \& Francis, New York, 2008.

KOUTAMANIS, Alexander. A Biased History of CAAD The Bibliographic Version. Artigo Universidade de Arquitetura de Netherlands ; 2005.

KRYGIEL, Eddy; NIES, Bradley. Green BIM: Successful Sustainable Design with Building Information Modeling. Indianapolis- Indiana: Liz Welch, 2008.

KRYGIEL, Eddy; VANDEZANDE, James. Mastering Autodesk Revit Architecture 2015. Sybex, Indianapolis- Indiana, 2014.

VIANNA, Nelson Solano; GONÇALVES, Joana Carla. Iluminação e Arquitetura. Virtus S/C Ltda, São Paulo, 2001.

ZEVI, Bruno. Saber Ver a Arquitetura. Editora Martins Fontes, São Paulo, 1996.

\subsection{SITES CITADOS}


HENRIQUES, Gonçalo Castro; BUENO, Ernesto. Geometrias Complexas e Desenho

Paramétrico. Drops, São Paulo, 10.030, Vitruvius, fev 2010 <http://www.vitruvius.com.br/revistas/read/drops/10.030/2109>.

http://lecomp.fau.unb.br/moodle/, acessado 02 de fevereiro de 2012

http://www.vitruvius.com.br/revistas/read/arquitextos/07.084/247, acessado 30 de abril de 2012

BOZDOC, Marian. The History of CAD, 2003, http://www.mbdesign.net/mbinfo/CADHistory.htm, acessado em 18 de abril de 2012

Autodesk ECOTECT Analysis -Visualize Sustainable Design http://images.autodesk.com/adsk/files/autodesk_ecotect_analysis_2011_brochure.pdf acessado em 01 junho de 2012

ARAGÂO, Anamaria et al. Programa de Revitalização dos Setores Centrais. 2009 http://www.sedhab.df.gov.br/projetos/Revitalizacao_Setores_Centrais/Revitalizacao_Se tores_Centrais.pdf

\subsection{REFERÊNCIAS BIBLIOGRÁFICAS CONSULTADAS}

ABIKO, Alex k.; ALMEIDA, Marco A.P. e BARREIROS, Mario A.F. Urbanismo: história e desenvolvimento. Texto técnico Escola Politécnica da USP; São Paulo, 1995.

GOUVÊA, Luiz Alberto. Biocidade: conceitos e critérios para um desenho ambiental urbano, em localidades de clima tropical de planalto. São Paulo: Nobel, 2002.

LIMA, João Filgueiras. O que é ser Arquiteto: memórias profissionais de Lelé; em depoimento a Cynara Menezes. Rio de Janeiro: Record, 2004.

RASMUSSEN, Steen Eiler. Arquitetura Vivenciada. 2 ed. São Paulo : M. Fontes, 1998.

RIBAS, Otto Ribas (organizador). Visões de Brasília: patrimônio, preservação \& desenvolvimento. Brasília: Instituto de Arquitetos do Brasil, 2005.

TOFFLER, ALVIN. O choque do Futuro. $4^{\mathrm{a}}$ ed. Tradução: Marcos Aurélio de Moura Matos. Editora Arte Nova, 1972. 